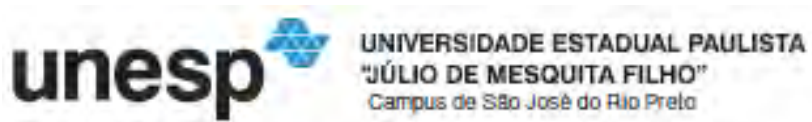

Instituto de Biociências Letras e Ciências Exatas

Ronaldo Montezuma

Perfil de textura em conserva de carne bovina (Corned Beef) submetida a diferentes tratamentos térmicos e sua relação com a concentração das proteínas dos tecidos muscular e conjuntivo colagenoso

São José do Rio Preto - SP 2010 


\section{Ronaldo Montezuma}

Perfil de textura em conserva de carne bovina (Corned Beef) submetida a diferentes tratamentos térmicos e sua relação com a concentração das proteínas dos tecidos muscular e conjuntivo colagenoso

Dissertação apresentada para obtenção do título de Mestre em Engenharia e Ciência de Alimentos, área de Engenharia de Alimentos junto ao Programa de Pós-Graduação em Engenharia e Ciência de Alimentos do Instituto de Biociências, Letras e Ciências Exatas da Universidade Estadual Paulista "Júlio de Mesquita Filho", Campus de São José do Rio Preto.

Orientador: Prof. Dr. Roger Darros Barbosa

São José do Rio Preto - SP 2010 


\section{Montezuma, Ronaldo.}

Perfil de textura em conserva de carne bovina (Corned Beef) submetida a diferentes tratamentos térmicos e sua relação com a concentração das proteínas dos tecidos muscular e conjuntivo colagenoso / Ronaldo Montezuma. - São José do Rio Preto : [s.n.], 2010.

147 f.: il. ; $30 \mathrm{~cm}$.

Orientador: Roger Darros-Barbosa

Dissertação (mestrado) - Universidade Estadual Paulista, Instituto de Biociências, Letras e Ciências Exatas

1. Carne bovina - Conservação. 2. Carne bovina - Textura. 3.

Proteínas do tecido muscular. 4. Proteínas do tecido conjuntivo. I.

Darros-Barbosa, Roger. II. Universidade Estadual Paulista, Instituto de

Biociências, Letras e Ciências Exatas. III. Título.

CDU - 637.5.033

Ficha catalográfica elaborada pela Biblioteca do IBILCE

Campus de São José do Rio Preto - UNESP 
Perfil de textura em conserva de carne bovina (Corned Beef) submetida a diferentes tratamentos térmicos e sua relação com a concentração das proteínas dos tecidos muscular e conjuntivo colagenoso

Dissertação apresentada para obtenção do título de Mestre em Engenharia e Ciência de Alimentos, área de Engenharia de Alimentos junto ao Programa de Pós-Graduação em Engenharia e Ciência de Alimentos do Instituto de Biociências, Letras e Ciências Exatas da Universidade Estadual Paulista "Júlio de Mesquita Filho", Campus de São José do Rio Preto.

\section{BANCA EXAMINADORA}

Prof. Dr. Roger Darros Barbosa

Orientador

UNESP - São José do Rio Preto

Prof. Dr. Pedro Fernando Romanelli

UNESP - São José do Rio Preto

Prof. Dr. Marcos Franke Pinto UNESP - Araçatuba

São José do Rio Preto, 26 de fevereiro de 2010. 


\section{AGRADECIMENTOS}

Ao nosso criador, expresso a minha maior gratidão pela minha vida e a oportunidade de servir como meio de sua auto realização neste mundo, através de sua suprema e absoluta sabedoria.

Aos meus antepassados, agradeço por terem me transmitido a vida e toda minha herança cultural e genética. Aos meus pais pela minha criação, dedicação e esforço abnegado para minha formação e educação.

A minha querida esposa Heloísa, dedico a realização deste sonho pelo seu incentivo, apoio e ajuda em todos os aspectos. Ao casal de educadores Prof. Dr. Sérgio Hugo Benez e Profa. Regina Benez pelo incentivo e inestimável ajuda para obtenção deste título.

Ao meu orientador e mestre Prof. Roger Darros Barbosa, pela sua ajuda, capacidade e persistência incansável em extrair o melhor de mim neste trabalho. A todos os meus mestres do curso de pós-graduação e em especial ao Prof. Pedro Fernando Romanelli pelo reconhecimento profissional e incentivo, a Profa. Célia Landi pelo apoio, a Profa. Vânia Nicoletti pela sua dedicação aos alunos. Ao Prof. Francisco Lopes pelas valiosas lições e ao Prof. Renato Cabral pela cooperação durante o estágio em docência.

Ao Prof. Marcos Franke pelo apoio, ajuda e desprendimento em proporcionar todas as condições para a realização da parte experimental no Departamento de Apoio e Produção Animal do Curso de Medicina Veterinária da UNESP - Campus de Araçatuba, juntamente com a valiosa assistência da Profa. Elisa Helena Giglio Ponsano. Ao Técnico em Química Sr. Alexandre Teixeira pela cooperação, grande ajuda e companheirismo na rotina dos ensaios experimentais. Aos Professores Luis Carlos Baida, Ariovaldo Banzzato e Silvia Helena Venturoli Perri pela valiosa colaboração na análise estatística. Ao Prof. Pedro Eduardo de Felício pela orientação e incentivo ao longo da minha carreira profissional.

Ao empresário Sr. Gustavo Penasso e toda a equipe do Frigorífico 4 Rios S.A. de Votuporanga (SP), pelo apoio, disponibilização das instalações, amostras e dados utilizados nesta pesquisa.

A todos os colaboradores da UNESP, colegas e amigos que adquiri no convívio destes anos em São José do Rio Preto e Araçatuba. 


\section{RESUMO}

O objetivo desta pesquisa foi determinar o Perfil de Textura (TPA) em formulações comerciais de "carne bovina em conserva" (corned beef) enlatada processada termicamente e avaliar sua relação com os valores de esterilização $\left(F_{0}\right)$, com a Concentração da Proteína do Tecido Conjuntivo Colagenoso (CCTP) e com a Concentração da Proteína do Tecido Muscular (MTP). Foram selecionados 14 lotes de produção de corned beef em latas tronco trapezoidais de $340 \mathrm{~g}$ correspondentes ao padrão continental Campden A e destes foram retiradas 24 latas do produto dos sub lotes submetidos ao processamento térmico. Destas latas foram retiradas seis amostras aleatórias para determinação do TPA e para análise da composição visando determinação da Proteína do Tecido Conjuntivo Colagenoso (CCTP), da Proteína do Tecido Muscular (MTP) e do Conteúdo Carne Magra (LMC). As latas de corned beef analisadas foram submetidas a tratamentos térmicos de 75,0 a 76,7 minutos, com a temperatura da autoclave a $121^{\circ} \mathrm{C}$ e resfriamento a $35^{\circ} \mathrm{C}$ durante 60 minutos, obtendo-se valores de $F_{0}$ no centro de massa do produto variando de 14,8 a 20 minutos. Os parâmetros de TPA dureza, fraturabilidade, coesividade, elasticidade, adesividade, mastigabilidade, gomosidade e resiliência foram determinados no bloco integral do produto bloco resfriado a $4^{\circ} \mathrm{C}$ em oito pontos na superfície. Os mesmos blocos do produto utilizados para determinação do TPA foram analisados quanto à composição média, apresentando concentração de 0,4 a 2,5\% para CCTP, de 21,7 a 25,3\% para MTP e de 102,79 a 107,95\% para LMC. Os tratamentos de corned beef avaliados apresentaram diferenças significativas pelo teste de Tukey nas médias dos parâmetros dureza, gomosidade, mastigabilidade, adesividade e elasticidade. Os três primeiros parâmetros apresentaram correlações significativas fortemente negativas com o valor de esterilização $F_{0}$. A MTP e o LMC apresentaram correlações significativas fortemente positivas com a coesividade. Verificou-se correlação significativa fortemente positiva do CCTP com a fraturabilidade e correlação significativa fortemente negativa com a coesividade. Para avaliar o efeito simultâneo do valor de esterilização e da composição nos Parâmetros de Textura, foi utilizado o Método de Superfície de Resposta. Para valores de $F_{0}$ 
de 14 a 17 minutos e MTP de 21,5 a $23,5 \%$ a dureza foi maior que $3 \mathrm{~N}$ e para o $F_{0}$ entre 15 e 18 minutos e CCTP de 1,8 a 2,4\% a adesividade máxima foi de -24 e -26 Ns e para $F_{0}$ entre 14 e 15 minutos a elasticidade máxima foi de 0,999 e 1,000. De modo geral, os resultados indicaram quais parâmetros de TPA são importantes para a qualidade deste produto: dureza, fraturabilidade, adesividade, elasticidade, coesividade e mastigabilidade. Os resultados obtidos nesta pesquisa demonstram que é possível reduzir o tempo de aquecimento no processamento térmico, diminuindo a taxa de ocupação das autoclaves aumentando assim a produtividade da planta com a mesma capacidade instalada, como também a redução de custos por unidade esterilizada, através da economia de energia no processo térmico. A redução da intensidade do tratamento térmico melhora as propriedades de textura do corned beef alcançando uma graduação de qualidade superior em relação ao mesmo padrão de produto.

Palavras chaves: corned beef, análise do perfil de textura; processamento térmico; valor de esterilização $\left(F_{0}\right)$; proteínas do tecido muscular, proteínas do tecido conjuntivo, declaração quantitativa de ingredientes (QUID). 


\begin{abstract}
The objectives of this research were the determination of the texture profile of canned corned beef thermally processed and to evaluate its relationship with the sterilization value $\left(F_{0}\right)$ and the composition. Fourteen production batches of Campden A grade 340-g corned beef cans were selected, from which twenty-four cans of the thermal process sub-batches were retrieved. From the sub-batches, six random sample cans were taken and its content submitted to the Texture Profile Analysis (TPA) and to the composition analysis to determine the concentration of the Collagenous Connective Tissue Protein (CCTP), the Muscular Tissue Protein (MTP) concentration and the Lean Meat Content (LMC). The corned beef samples analyzed were submitted to thermal treatments at $121^{\circ} \mathrm{C}$ (retort steam temperature) for varying heating times, from 75 to 76 minutes and cooled at $35^{\circ} \mathrm{C}$ (retort water temperature) during 35 minutes, to obtain $F_{0}$ values at the product center point varying from 14.8 to 20 minutes. The TPA parameters were determined in 8 points of the whole corned beef loaf of each sample, previously chilled and stabilized at $4{ }^{\circ} \mathrm{C}$ temperature, to obtain hardness, fracturability, cohesiveness, elasticity, adhesiveness, springiness, gumminess, chewiness and resilience. The same sample material were then analyzed in terms of average composition of the product, resulting in concentrations in the range of 0.4 to $2.5 \%$ for CCTP, 21.7 to $25.3 \%$ for MTP and content from $102.8 \%$ to $108.0 \%$ for LMC. The treated corned beef samples analyzed showed significant differences in the means for hardness, adhesiveness, chewiness and elasticity. These parameters showed dependence with the sterilization value $\left(F_{0}\right)$, revealing negative strong significant correlation for $F_{0}$ with hardness, gumminess and chewiness. The MTP and LMC values showed a high positive significant correlation with cohesiveness. It was observed a high positive significant correlation of CCTP with fracturability and a high negative significant correlation of CCTP with cohesiveness. The response surface methodology was used to evaluate the simultaneous effect of the sterilization value and the composition on texture parameters. Hardness was greater than $3 \mathrm{~N}$ for $F_{0}$ values varying from 14 to 17 minutes and MTP from $21.5 \%$ to $23.5 \%$. Maximum adhesiveness was reached at values from -24 to -
\end{abstract}


$26 \mathrm{Ns}$ for $F_{0}$ values varying from 15 to 18 minutes and CCTP from 1.8 to 2.4\%. Maximum elasticity was achieved at 0.999 to 1.000 for $F_{0}$ values between 14 and 15 minutes. In general, the results indicated which TPA parameters were considered important and significant for corned beef quality as shown for hardness, fracturability, adhesiveness, springiness cohesiveness and chewiness. The results indicate that it is possible to reduce the processing time in the heating phase, thus increasing the retort and plant output and reducing operational costs through energy savings. Reducing the severerity of the thermal treatment also brings texture improvements for the corned beef, in order to achieve superior quality grade levels.

Key words: corned beef; texture profile analysis; thermal processing; sterilization value $\left(F_{0}\right)$; muscular tissue proteins; collagen tissue proteins; quantitative declaration of ingredients (QUID). 


\section{ÍNDICE}

Páginas

1. INTRODUÇÃO 16

$\begin{array}{lr}\text { 2. OBJETIVOS } & 18\end{array}$

3. CONTEXTO E JUSTIFICATIVA DA PESQUISA 19

4. REVISÃO BIBLIOGRÁFICA 22

4.1. Identidade e qualidade da carne bovina em conserva (Corned Beef) 22

4.2. Processamento térmico em alimentos embalados hermeticamente

4.3. Gelificação e alterações no tecido muscular dos sistemas cárneos durante o cozimento 28

4.4. Propriedades de textura e Análise do Perfil de Textura (TPA) 33

5. MATERIAIS E MÉTODOS 40

5.1. Preparação do Corned Beef 40

5.2. Enlatamento 42

5.3. Processamento térmico em autoclave horizontal e $\begin{array}{ll}\text { penetração de calor } & 42\end{array}$

5.4. Análise do Perfil de Textura do Corned Beef 44

5.5. Análise da composição do Corned Beef 51

5.6. Análise de dados e delineamento experimental 58

6. RESULTADOS E DISCUSSÃO 61

6.1. Perfil de temperatura e valor de esterilização 61

6.2. Perfil de textura - TPA 66

6.3. Composição do Corned Beef dos tratamentos 68

6.4. Análise de variância dos efeitos dos tratamentos $\left(F_{0}\right)$ e da posição de medição do TPA no bloco de Corned Beef 71

6.5. Análise de correlação entre o tratamento térmico, a composição e os parâmetros de perfil de textura 76

6.6. Efeito simultâneo do tratamento térmico e da $\begin{array}{ll}\text { composição no perfil de textura } & 78\end{array}$

$\begin{array}{ll}\text { 7. CONCLUSÃO } & 87\end{array}$ 


\section{ANEXOS}

Anexo 1. Análises por métodos rápidos da composição dos lotes do misturador na preparação do corned beef

Anexo 2. Cartas gráficas e planilhas operacionais dos processamentos térmicos dos tratamentos

Anexo 3. Resultados das análises sensoriais realizadas pelos analistas de qualidade da indústria

Anexo 4. Resultados das Análises do Perfil de Textura 


\section{ÍNDICE DE TABELAS}

Páginas

Tabela 1. Processo térmico comercial otimizado para microorganismos e cozimento de corned beef

Tabela 2. Fórmula base dos lotes de corned beef conforme padrão continental Premium classificação Campden A

Tabela 3. Resumo das condições do processamento térmico aplicado nos lotes de corned beef

Tabela 4. Delineamento experimental em blocos casualizados

Tabela 5. Valores de Esterilização calculados $\left(F_{h}\right),\left(F_{c}\right)$ e $\left(F_{0}\right)$ para os tratamentos térmicos

Tabela 6. Resultados das medidas dos parâmetros de TPA repetidos em oito pontos do bloco das amostras de corned beef

Tabela 7. Composição média do bloco integral de corned beef homogeneizado para cada tratamento

Tabela 8. Análise de Variância (ANOVA) dos efeitos dos seis fatores de tratamento $\left(F_{0}\right)$ em oito blocos

Tabelas 9a e 9b. Médias homogêneas agrupadas pelo Teste de Tukey $5 \%$ dos parâmetros de TPA dos sub lotes de corned beef

Tabela 10. Coeficientes de Pearson - Análise de Correlação entre o Tratamento Térmico, Composição e TPA

Tabela 11. Resultados da Média dos parâmetros de TPA e Composição Média (MTP e LMC e CCTP) dos lotes de corned beef submetidos aos tratamentos de $F_{0}$ 


\section{ÍNDICE DE FIGURAS}

Páginas

Figura 1. Curva típica do TPA no texturômetro GF

Figura 2. Posicionamento das latas com os termopares no Processamento térmico em autoclave 43

Figura 3. Texturômetro TA modelo XT2i da Micro Systems 44

Figura 4. Esquema da localização dos pontos de penetração da sonda no bloco integral de corned beef

Figuras 5a e 5b. Fotos mostrando a medição da temperatura (a) e pontos de penetração da ponta de prova do texturômetro (b) $\quad 48$

Figuras 6a e 6b. Fotos mostrando a ponta de prova (a) e a penetração da sonda no bloco integral de corned beef (b)

Figura 7. Amostra do bloco integral resfriado de corned beef após determinação do TPA

Figura 8. Tratamento 1 - Curva de penetração de calor

Figura 9. Tratamento 2 - Curva de penetração de calor

Figura 10. Tratamento 3 - Curva de penetração de calor

Figura 11. Tratamento 4 - Curva de penetração de calor

Figura 12. Tratamento 5 - Curva de penetração de calor

Figura 13. Tratamento 6 - Curva de penetração de calor

Figura 14. Superfície de resposta da adesividade em função de CCTP e $F_{0}$.

Figura 15. Superfície de resposta da elasticidade em função de CCTP e $F_{0}$.

Figura 16. Superfície de resposta da dureza em função de MTPe $\quad F_{0}$.

Figura 17. Superfície de resposta da gomosidade em função de $M T P$ e $F_{0}$.

Figura 18. Superfície de resposta da mastigabilidade em função de MTP e $F_{0}$.

Figura 19. Superfície de resposta da coesividade em função de $M T P$ e $F_{0}$.

Figura 20. Superfície de resposta da fraturabilidade em função de CCTP e 


\section{SIMBOLOGIA}

A Área da seção transversal $\left(\mathrm{m}^{2}\right)$ submetida a uma tensão ou pressão nas equações do módulo de elasticidade

Co Valor de cozimento para determinado parâmetro de textura a uma temperatura de referência $(\mathrm{min})$

d Diâmetro do cilindro, Equação $08(\mathrm{~mm})$

$D \quad$ Tempo de redução decimal a temperatura $T$ de referência $(\mathrm{min})$

$F \quad$ Força $(\mathrm{N})$

$F_{0} \quad$ Valor de esterilização para uma temperatura de referência (min)

$F_{c} \quad$ Valor de esterilização na fase de resfriamento para uma temperatura de referência $(\mathrm{min})$

$F_{h} \quad$ Valor de esterilização na fase de aquecimento para uma temperatura de referência ( $\mathrm{min}$ )

$L \quad$ Taxa de letalidade, definida pela Equação 3 (min)

I Comprimento do cilindro, Equação $08(\mathrm{~mm})$

$P \quad$ Pressão $(\mathrm{Pa})$

$p \quad$ Valor $p$ de probabilidade

$R^{2} \quad$ Coeficiente de Determinação

$r$ Coeficientes de Correlação de Pearson

$s \quad$ Tempo (s)

$T \quad$ Temperatura $\left({ }^{\circ} \mathrm{C}\right)$

$T_{c} \quad$ Temperatura resfriamento $\left({ }^{\circ} \mathrm{C}\right)$

$T_{h} \quad$ Temperatura aquecimento $\left({ }^{\circ} \mathrm{C}\right)$

$t \quad$ Tempo (min)

$t_{\text {stat }} \quad$ Valor $t$ estatístico (teste $t$ de Student)

$V \quad$ Volume $\left(\mathrm{m}^{3}\right)$

$z \quad$ Valor $z$ do microrganismo $\left({ }^{\circ} \mathrm{C}\right)$

$z_{c} \quad$ Valor $z$ do cozimento para parâmetros de textura $\left({ }^{\circ} \mathrm{C}\right)$ 


\section{LETRAS GREGAS}

$\Delta / \quad$ Variação do comprimento causado pela aplicação da força ( $\mathrm{mm}$ )

$\sigma \quad$ Tensão de cisalhamento $(\mathrm{Pa})$

$\dot{\gamma} \quad$ Taxa de deformação $\left(\mathrm{s}^{-1}\right)$

$\mu \quad$ Viscosidade (Pa.s)

$\dot{\mu} \quad$ Relação de Poisson

\section{ABREVIATURAS}

CTP Concentração da Proteína do Tecido Conjuntivo $\left(\mathrm{g} / 100 \mathrm{~g}^{-1}\right)$

CCTP Concentração da Proteína do Tecido Conjuntivo Colagenoso $\left(\mathrm{g} / 100 \mathrm{~g}^{-1}\right)$

LMC Conteúdo de Carne Magra (crua) (\% massa/massa)

MTP Concentração da Proteína do Tecido Muscular livre de tecido colagenoso $=T M P-\operatorname{CCTP}\left(\mathrm{g} / 100 \mathrm{~g}^{-1}\right)$

TMC Conteúdo Total de Carne (crua) $\left(\mathrm{g} / 100 \mathrm{~g}^{-1}\right)$

TPA Análise do Perfil de Textura

TMP Concentração da Proteína Total da Carne $\left(\mathrm{g} / 100 \mathrm{~g}^{-1}\right)$ 


\section{INTRODUÇÃO}

As mudanças econômicas e sociais que tem alterado o perfil da família tradicional têm impulsionado e aprimorado o segmento de serviços de alimentação como restaurantes self service, fast foods e cozinhas industriais. As indústrias de carnes e refeições prontas para consumo tendem a ocupar uma grande fatia deste mercado com alimentos termicamente processados e relativamente estáveis à temperatura ambiente, desde que o processo utilizado preserve as características naturais de sabor e nutrientes e que os produtos ofereçam qualidade culinária, variação do cardápio, custo competitivo e segurança alimentar. Dentre esses, destaca-se o corned beef, produto de recortes e retalhos de carne de carcaça bovina, picados, curados e pré-cozidos, acondicionado em embalagem hermética e submetido a tratamento térmico.

O produto corned beef tem origem da antiga prática de preservar cortes de carne bovina, por meio da salga e cura seca (corning) com "grãos" de sal de rocha (corn) do tamanho de grãos de milho. A denominação corning deste processo tem origem do inglês antigo proveniente dos dialetos dos povos anglo-saxões (UNITED STATES DEPARTMENT OF AGRICULTUREUSDA, 2008). A outra forma do produto é uma conserva de carne enlatada e de origem militar, correspondente ao produto comercial atual composto de recortes e retalhos (trimmings) de carne bovina. Esta forma é muito popular no Reino Unido desde o início do século XIX, quando se tornou uma opção acessível para substituir a carne fresca. Durante décadas o produto foi exportado em larga escala para a Europa pela Companhia Anglo que foi pioneira na produção de corned beef enlatado na cidade de Fray Bentos no Uruguai. Argentina e Uruguai durante anos foram líderes na produção de corned beef. Atualmente, o Brasil é o maior produtor e exportador de corned beef enlatado do mundo.

Devido à dificuldade de produção do padrão continental de primeira (Premium) ou Campden Grade $A^{*}$ (CAMPDEN \& CHORELYWOOD FOOD RESEARCH ASSOCIATION - CCFRA, 2001) com custo competitivo, em função do custo mais elevado e disponibilidade de matérias primas, é importante otimizar o controle da formulação (carne e tendões pré-cozidos, 
gordura) através de análises rápidas baseadas na determinação mais precisa do "conteúdo de carne magra" (Lean Meat Content, LMC) e das variáveis "proteína do tecido conjuntivo colagenoso" (Colagenous Conective Tissue Protein, CCTP) e "proteína do tecido muscular" (Muscular Tissue Protein, MTP) devido à importância da função do colágeno na gelificação de misturas de carnes previamente cozidas para efeito de reestruturação.

É de fundamental importância o entendimento da complexa relação entre os componentes que constituem o corned beef e a sua relação com os atributos de qualidade sensorial como sabor e textura resultantes após o tratamento térmico. Em especial, deve-se considerar a funcionalidade das proteínas presentes, entre as quais a miosina, tropomiosina, troponina, actina e o colágeno, a solubilização e insolubilização, a desnaturação e formação de gel, em relação ao comportamento físico-químico, estrutura e consistência determinantes para as características de textura do produto. Neste contexto, a complexidade do mecanismo e ação depende entre outros fatores dos tipos e proporção das proteínas e outros compostos (água, gordura e sais), da temperatura e da taxa de aquecimento.

A determinação de parâmetros de textura dependentes do aquecimento e composição, significativos neste produto, tal qual proposta no presente trabalho, visa contribuir para a determinação dos parâmetros cinéticos de textura para a otimização do processamento térmico em relação ao cozimento (textura) e esterilização (microorganismos). Espera-se desta aplicação a diminuição do custo por unidade esterilizada através da economia de energia no processo e também otimizar as propriedades de textura do corned beef visando alcançar uma graduação de qualidade superior em relação à textura e composição, de modo que possam ser utilizados no processo industrial para reduzir o índice de não conformidades. 


\section{OBJETIVOS}

O objetivo desta pesquisa consistiu em determinar os parâmetros dureza, fraturabilidade, adesividade, elasticidade, coesividade, gomosidade, mastigabilidade e resiliência, relativos ao perfil de textura instrumental do corned beef e correlacioná-los com a intensidade do tratamento térmico e com a composição do corned beef. Para a intensidade do tratamento térmico foi considerado o histórico tempo e temperatura do processamento térmico aplicado nos produtos e nos valores de esterilização calculados, para garantir segurança alimentar. Para a composição do corned beef, esta foi avaliada em termos de umidade, proteínas, lipídeos, carboidratos, cinzas, sal adicionado, conteúdo de hidroxiprolina, e cálculo do "conteúdo de carne magra" (Lean Meat Content, $L M C$ ), da "concentração de proteína do tecido conjuntivo colagenoso" (Colagenous Conective Tissue Protein, CCTP) e da "concentração de proteína do tecido muscular" (Muscular Tissue Protein, MTP). 


\section{CONTEXTO E JUSTIFICATIVA DA PESQUISA}

Os alimentos prontos para consumo requerem processamento $\mathrm{e}$ embalagem adequados para sua conservação e comercialização. O processamento térmico dos alimentos acondicionados em latas é um dos métodos mais comuns para preservação, embora sejam necessários grandes investimentos de capital em instalações e equipamentos (WILLIAMS, STEFFE, BLACK, 1981; JUN, COX, HUANG, 2006). Além disso, o processo térmico usualmente aplicado para a esterilização comercial dos alimentos pode modificar significativamente suas propriedades sensoriais e nutricionais em relação aos alimentos apenas cozidos e mantidos congelados ou resfriados. Este é um dos motivos pelos quais os consumidores têm dado preferência aos alimentos frescos preservados pelo congelamento ou resfriamento, embalados a vácuo ou em atmosfera modificada, em detrimento das conservas em embalagens metálicas (JUN, COX, HUANG, 2006).

Nas últimas décadas, houve muitos avanços com o propósito de melhorar a segurança das latas para acondicionamento e processamento térmico de alimentos entre os quais se destaca a soldagem elétrica da folha de aço protegida pelo revestimento eletrostático com poliéster em pó atóxico e a formação do corpo da lata a partir de uma peça única através da estampagem e expansão. Apesar destes avanços associados com as condições de sanidade e segurança dos processos atuais dos alimentos de baixa acidez, são muitos os pontos críticos a serem controlados no sistema de segurança alimentar no processo de enlatamento, através do emprego da Análise de Perigo e Pontos Críticos de Controle - APPCC. Neste sentido podem-se considerar as seguintes etapas inerentes ao processo de enlatamento: (1) Aplicação e secagem do vedante de borracha nos canais (curling) das tampas, (2) envernizamento da folha metálica para evitar reações químicas e a contaminação do alimento pela migração de metais pesados das folhas de aço cromadas ou estanhados, (3) fechamento mecânico (recravação) das bordas (flange e curling) que deve ser rigorosamente controlado para garantir a estanqueidade das latas, e (4) secagem e manuseio das latas após o resfriamento de modo a evitar contaminações microbianas pós processamento térmico por microrganismos 
presentes na superfície molhada das latas através de micro-furos do vedante de borracha, enquanto este estiver quente e úmido (CODEX ALIMENTARIUS COMMISSION, 1979).

Por outro lado a preservação dos fatores de qualidade nutricional e sensorial, notadamente o sabor e a textura, através da otimização do processamento térmico tem sido relevada, embora haja soluções oriundas de pesquisas nesta área e a disponibilidade de novos sistemas e tecnologias de processamento térmico, tais como: (1) autoclaves com agitação que ocasionam o movimento do produto no interior da embalagem e a transferência de calor pelo meio de aquecimento por convecção forçada, reduzindo o tempo de aquecimento do produto (2) autoclaves com controle preciso da pressão e da sobre-pressão para evitar a expansão das embalagens flexíveis e das metálicas de paredes mais finas pela pressão interna formada durante o aquecimento do produto, (3) embalagens flexíveis tipo retortable pouches e bandejas plásticas cujas características de formato e flexibilidade possibilitam o enchimento do produto resultando em uma geometria com menor espessura e uma maior área para transferência de calor na direção da penetração do calor.

As conservas de carne e as refeições prontas termicamente processadas, as quais não necessitam de refrigeração para sua preservação, tais como, corned beef, fiambres, salsichas, almôndegas e feijoada fazem parte de uma conveniente alternativa para suprir uma parte da demanda de mercado por pratos prontos a base de carne. A melhoria da qualidade através da otimização do processamento térmico para uma maior preservação dos fatores de qualidade nutricional e sensorial aumenta a aceitação do consumidor por estes produtos e, particularmente para o corned beef possibilita atingir padrões mais altos de qualidade e aumentando o valor agregado do produto.

Os segmentos varejista e atacadista desejam que os derivados de carne bovina tenham uma vida de prateleira mais prolongada, enquanto que os processadores de carnes precisam de alternativas em produtos comerciais para os cortes de menor preferência e, portanto, de menor valor de mercado, para tanto, considera-se o processamento térmico como uma forma de melhorar e padronizar a qualidade destes cortes (JUN, COX, HUANG, 2006). 
Devido à globalização da economia, o corned beef tornou-se muito popular também nos mercados emergentes. Este produto tem uma importante participação nas exportações brasileiras de carnes industrializadas. Sua fabricação agrega valor à expressiva quantidade de retalhos de carne e tecidos não musculares. Estas matérias primas são geradas secundariamente, nas operações de abate e desossa de carcaças, para obtenção de cortes anatômicos in natura e também cortes e porções destinadas ao cozimento para produção de carnes prontas congeladas. No processo industrial de preparação do corned beef, estas matérias primas são cozidas antes do envase, extraindo-se o caldo de carne que é posteriormente concentrado para a obtenção do valorizado extrato de carne.

Os produtos de carnes bovinas industrializadas representam uma significativa fonte de divisas e arrecadação tributária. Segundo dados do MDIC (Ministério do Desenvolvimento, Indústria e Comércio Exterior, 2008), no período de janeiro a novembro de 2008, a quantidade de carnes industrializadas alcançou 183.580,25 toneladas (19,10\%) em relação ao total de carne bovina in natura exportada de 960.981,63 toneladas e contribuíram com o valor de US\$ 784.023,75 (20,69\%) em relação ao valor total (US\$ $3.790125,48)$ da carne bovina in natura exportada. A taxa de crescimento do valor exportado sobre o mesmo período do ano anterior foi de $22 \%$. 


\section{REVISÃO BIBLIOGRÁFICA}

\subsection{Identidade e qualidade da carne bovina em conserva (Corned Beef)}

Corned beef é definido internacionalmente como um produto de carne de carcaça das espécies bovinas, desossada, picada, curada e pode incluir carne de cabeça, carne de coração e carne de diafragma. O produto deve ser preparado de cortes de carnes bovinas cozidas e picadas grossas (moídas em disco com furos de $1 / 2$ a 1 polegada de diâmetro) ou pode ser adicionada a esta mistura de carnes cozidas uma quantidade de $5 \%$ de carne crua. Em ambos os casos todas as carnes poderão ser curadas antes ou após o envase. $O$ tratamento térmico deve ser aplicado após a embalagem hermética e deverá ser dimensionado para assegurar que produto seja estável a temperatura ambiente e não apresente risco à saúde pública (CODEX ALIMENTARIUS COMMISSION, 1991).

De acordo com a especificação da Campden \& Chorelywood Food Research Association - CCFRA (2001) o produto deve ter no mínimo 120\% do equivalente ao conteúdo total de carne crua (raw meat equivalent) e $96 \%$ mínimo do equivalente ao conteúdo de carne crua magra (lean meat content). Estes valores são correspondentes na prática ao conteúdo equivalente de carne crua que foi cozida e adicionada na formulação.

Com a introdução da definição européia harmonizada do termo 'carne', o "conteúdo de carne" (meat content) declarado nos produtos com carne na sua composição deverá estar de acordo com a nova definição. Como o produto final corned beef é usualmente utilizado como ingrediente em alimentos comercializados pré embalados ou a granel, o cálculo do meat content deverá estar de acordo com o conceito em vigor. O novo conceito considera 'carne' apenas os músculos esqueléticos, diafragma, masseteres com sua composição natural de tecido conjuntivo e gordura aderida, devendo ser declarado o excesso destes tecidos na Declaração Quantitativa de Ingredientes (QUID) na sua rotulagem (UNIÃO EUROPÉIA, 2005).

A adição de açúcar (sacarose, açúcar invertido, dextrose, lactose, maltose ou xarope de milho) é opcional, sendo que o conteúdo expresso como sacarose deve ser $1 \%$, porém, não deve exceder a $2 \%$. São 
considerados ingredientes essenciais o cloreto de sódio (2 a 2,5\%) e o nitrito de sódio ou potássio, expresso como nitrito de sódio, na quantidade máxima de $100 \mathrm{mg} / \mathrm{kg}$.

\subsection{Processamento térmico de alimentos embalados hermeticamente}

Os alimentos enlatados de menor consistência, relacionados com o modo de aquecimento por convecção, movimentam-se continuamente no processamento térmico, uniformizando razoavelmente a temperatura dentro da embalagem. Por outro lado nos alimentos de maior consistência, relacionados com o modo de aquecimento condutivo, devido à ausência de movimento durante o processo térmico há sempre um gradiente de temperatura significativo entre o produto na superfície em contato com a parede da embalagem e a região do centro geométrico, considerado ponto de aquecimento e resfriamento mais lento (STUMBO, 1973).

A esterilização comercial das conservas de carne bovina compactada do tipo corned beef apresenta o modelo de aquecimento condutivo no processamento térmico. Devido à falta de movimento dos pedaços de carne durante 0 processo térmico há sempre um gradiente de temperatura significativo entre a superfície em contato com a embalagem e seu ponto central geométrico. Até o centro de massa atingir a temperatura da superfície, geralmente ocorre um cozimento excessivo nas porções próximas à superfície ocasionando redução dos fatores de qualidade e propriedades de textura indesejáveis. Este fato pode acarretar sabor de queimado, desagregação e amolecimento da estrutura do bloco de carne, notadamente nas porções superficiais, principalmente nos produtos que são processados durante um tempo mais longo, devido as suas características de aquecimento.

No tratamento térmico para destruição dos microrganismos o parâmetro cinético "tempo de redução decimal" ou valor $D$, que representa o tempo requerido para a destruição de $90 \%$ da população inicial de microrganismos presentes no alimento, ou seja, o tempo necessário para a curva de morte térmica atravessar um ciclo logarítmico, pode ser também usado para representar o tempo de redução decimal da concentração dos 
fatores de qualidade termo lábeis degradados no processamento térmico dos alimentos. A redução exponencial na concentração de qualquer fator vulnerável ao calor que pode ser reduzido com o tempo de aquecimento, a uma dada temperatura constante, pode ser descrita por uma curva de sobreviventes, conforme expressada matematicamente pela Equação 1, onde as concentrações dos fatores de qualidade termo lábeis, inicial e final, são representados na forma logarítmica por $\log a$ e $\log b$, respectivamente, e o tempo de tratamento designado como $F$ à temperatura constante (STUMBO, 1973).

$$
F=D(\log a-\log b)
$$

Para um processo térmico real, no qual a temperatura do interior do alimento é variável com o tempo e posição, pode-se usar o valor de esterilização $F_{0}$ ou valor de cozimento $C_{0}$ que corresponde ao tempo necessário em minutos que o alimento deve permanecer a uma temperatura de referência para que ocorra a redução decimal determinada de microrganismos ou fatores de qualidade, respectivamente. A temperatura de $121,1^{\circ} \mathrm{C}$ é usada como referência para esterilização de alimentos de baixa acidez com o objetivo de destruir os microorganismos patogênicos e deterioradores resistentes ao calor enquanto que a temperatura de $100^{\circ} \mathrm{C}$ é utilizada como referência para o cozimento.

O valor $z$, representado matematicamente pela Equação 2, segue a mesma analogia anterior. Este parâmetro cinético corresponde à energia de ativação da reação cinética correspondente ao acréscimo de temperatura necessário $\left(T_{2}-T_{1}\right)$ para que o valor $D$ sofra uma redução decimal (log $\left(D_{1} / D_{2}\right)$ ), ou seja, para produzir uma redução decimal do tempo de redução de $90 \%$ da população microbiana ou de redução de $90 \%$ da concentração do fator de qualidade termo lábil.

$$
z=\frac{\left(T_{2}-T_{1}\right)}{\log \left(D_{1} / D_{2}\right)}
$$


A relação $D_{\text {ref }} / D$ entre o tempo à temperatura de referência e o tempo à temperatura do processo real ou taxa letal $L$ é representada matematicamente pela Equação 3. Esta descreve a taxa de destruição dos microrganismos ou degradação do fator de qualidade a uma temperatura de referência $\left(T_{\text {ref }}\right)$ : por exemplo, $121,1^{\circ} \mathrm{C}$ para esterilização ou $100^{\circ} \mathrm{C}$ para cozimento, corresponde a um minuto a temperatura $(T)$ do processo.

$$
L=10^{\frac{\left(T-T_{\text {erf }}\right)}{z}}
$$

O cálculo dos valores de esterilização ou cozimento pode ser feito pela integração das taxas letais obtidas de acordo com as temperaturas medidas em determinado ponto do alimento durante o seu aquecimento e resfriamento a que o alimento é submetido durante o tratamento térmico. Segundo o método simplificado proposto por Patachnik (1953), o valor de esterilização ou cozimento consiste no somatório das letalidades em intervalos iguais de tempo fornecido pelas Equações $4 a$ e $4 b$ respectivamente.

$$
F_{o}=\int_{0}^{t} \frac{1}{10^{\frac{121,1,-T}{z}}} d t
$$

$$
C_{0}=\int_{0}^{t} \frac{1}{10^{\frac{100-T}{z_{c}}}} d t
$$

No caso da esterilização de alimentos de baixa acidez, levando em consideração o risco à saúde pública, o microrganismo de referência a ser destruído pelo processo térmico é o Clostridium botulinum com um valor $z$ de $10^{\circ} \mathrm{C}$. No entanto, o microrganismo tipicamente empregado para assegurar a esterilização comercial é o Clostridium sporogenes (PA 3679), um organismo muito similar ao Clostridium botulinum, mas com resistência térmica mais alta (HOLDSWORTH, SIMPSON, 2008). RHA (1967) determinou a resistência térmica do PA 3679 em carne bovina, sem adição de nitrito, para a predição da esterilidade comercial de carne bovina (músculo semitendinoso) moída embalada em pouches, processada termicamente em imersão em água aquecida. Os valores encontrados na faixa de temperatura de 107,2 a $121,1^{\circ} \mathrm{C}$, foram $D_{121{ }^{\circ} \mathrm{C}}$ de 1,2 minutos e $z$ de $10,5^{\circ} \mathrm{C}$. Estes valores estão 
dentro da faixa dos valores relatados para alimentos de baixa acidez (STUMBO, 1973; BERRY, PFLUG, 1993).

O Ministério de Agricultura Pecuária e Abastecimento (MAPA) do Brasil regulamenta para carne bovina em conserva (corned beef) um valor de esterilização mínimo equivalente a 3 minutos a $121,1^{\circ} \mathrm{C}$. O Regulamento Técnico de Identidade e Qualidade de Carne Bovina em Conserva - Corned Beef (BRASIL, 2003), estabelece:

"Quando da apresentação ao DIPOA dos documentos referentes à homologação do processamento térmico de produtos submetidos à esterilização comercial, as empresas devem indicar o valor de esterilização desejado, sendo que em nenhuma hipótese esse valor poderá ser inferior ao equivalente a 3 minutos a $250^{\circ} \mathrm{F}$, com o parâmetro microbiológico $z=$ $18^{\circ} \mathrm{F}^{\prime \prime}$.

Para avaliação do processo térmico aplicado ao corned beef, usa-se como referência o microrganismo Clostridium sporogenes (PA 3679), com o valor $D_{121,10 \mathrm{C}}$ de 1,2 minutos e $z$ de $10^{\circ} \mathrm{C}$, e uma destruição cinco vezes o valor $D(5 D)$ para obter a esterilização comercial (UNITED STATES OF AMERICA, 2005), tendo em vista que usualmente este tipo de produto (corned beef) é exportado em larga escala para os Estados Unidos, tendo que atender a legislação daquele país. Estes valores correspondem a um valor de esterilização $F_{0}$ de 6,0 minutos, satisfazendo os requisitos de segurança alimentar e estabilidade microbiológica do produto tanto para a legislação brasileira quanto norte-americana.

O calor aplicado para a inativação dos microrganismos e o cozimento dos alimentos, em muitos casos, altera as propriedades organolépticas e fatores nutricionais dos alimentos como, por exemplo, a cor, textura, sabor e vitaminas termo lábeis. A concentração dos fatores vulneráveis ao calor decresce exponencialmente de modo análogo a redução de uma determinada população microbiana pela aplicação de calor a uma temperatura constante (STUMBO, 1973; HOLDSWORTH, SIMPSON, 2008).

Quando processamos termicamente os alimentos para eliminação dos microrganismos ocorrem também reações químicas e físico-químicas desejáveis, porém muitas vezes intensas como a inativação de enzimas, o cozimento e o amaciamento. Ocorrem também reações indesejáveis como a destruição de nutrientes e perda das qualidades organolépticas como cor, 
textura e sabor. Estas reações são de natureza química e podem ser mais ou menos dependentes do calor do que a reação de destruição dos microrganismos. Por estas razões, os processos térmicos devem ser dimensionados para a segurança alimentar, mas ao mesmo tempo otimizados em relação à retenção dos fatores de qualidade, seja para minimização dos fatores indesejáveis como para maximização dos desejáveis (HOLDSWORTH, SIMPSON, 2008).

Segundo Holdsworth e Simpson (2008) existem inúmeras pesquisas sobre estes constituintes denominados fatores cinéticos para os atributos de qualidade que podem ser usados como indicativos de degradação dos fatores de qualidade em determinados alimentos. Estes autores os compilaram da seguinte forma: degradação de vitaminas, ex. tiamina em produtos de carne e pescados, beta caroteno em pasta de fígado e suco de cenoura; desnaturação de aminoácidos, ex. creatinina no caldo e extrato de carne, lisina no feijão e metionina no leite; desnaturação de enzimas, ex. peroxidase, catalase, lipoxigenase, polifenoloxidase em vegetais, frutas e grãos; qualidade sensorial geral, ex. purê de carne, cenoura, milho; propriedades de textura e amolecimento, ex. feijão, camarão e carne; degradação da cor, ex. clorofila em aspargos e reação de douramento de pasta de castanha e purê de pêssego.

Tuckler e Holdsworth (1991) compilaram trabalhos de otimização do processamento térmico de vários produtos através do método gráfico, plotando os valores de $F_{0}$ e $C_{0}$ obtidos no aquecimento instantâneo seguido do resfriamento instantâneo de uma fina porção superficial do produto. Destacam-se os dados do processo para o corned beef apresentado na Tabela 1 (HOLDSWORTH, SIMPSON, 2008).

Tabela 1. Processo térmico comercial otimizado para microorganismos e cozimento de corned beef (HOLDSWORTH, SIMPSON, 2008).

\begin{tabular}{cccccc}
\hline Produto & $\begin{array}{c}\text { Tamanho da } \\
\text { embalagem } \\
(\mathrm{mm})\end{array}$ & $\begin{array}{c}\text { Temperatura } \\
\text { de processo } \\
\left({ }^{\circ} \mathrm{C}\right)\end{array}$ & $\begin{array}{c}\text { Tempo de } \\
\text { processo } \\
(\mathrm{min})\end{array}$ & $\begin{array}{c}\mathrm{F}_{121,1^{\circ} \mathrm{C}} \\
(\text { centro }) \\
(\mathrm{min})\end{array}$ & $\begin{array}{c}\mathrm{C}_{121,1^{\circ} \mathrm{C}} \\
(\text { médio }) \\
(\mathrm{min})\end{array}$ \\
\hline $\begin{array}{c}\text { Corned } \\
\text { beef }\end{array}$ & $300 \times 200$ & 121,1 & 39 & 6,6 & 80,9 \\
\hline
\end{tabular}




\subsection{Gelificação e alterações no tecido muscular dos sistemas cárneos durante o cozimento}

A funcionalidade das proteínas dos alimentos cárneos em relação ao seu comportamento físico-químico afeta as características de qualidade dos produtos finais. No processamento de carnes, esta funcionalidade representa o comportamento reológico da formação de gel, as propriedades de textura e de ligação. A gelificação das proteínas musculares induzida pelo calor é de fundamental importância no processamento e determinante para as características de textura dos produtos cárneos.

Muitos destes produtos derivados de carne, como os embutidos e as carnes reconstituídas, na sua preparação, são finamente triturados $e$ homogeneizados com água e sais. A miosina é a mais abundante das estruturas protéicas na carne e tem papel importante na gelificação. $O$ processo começa com a desnaturação parcial das moléculas das proteínas e a exposição dos locais de ligação para a agregação das mesmas. Durante o aquecimento, as proteínas miofibrilares solubilizadas começam a desnaturar as temperaturas entre 30 e $32^{\circ} \mathrm{C}$ e agregam-se entre 30 e $40^{\circ} \mathrm{C}$, seguindo a gelificação entre 45 e $50^{\circ} \mathrm{C}$. Este fenômeno consiste na formação de uma rede tridimensional de gel cuja estrutura e consistência dependem dos tipos das proteínas, suas características intrínsecas e quantidades, do $\mathrm{pH}$ e presença de íons, da temperatura e da taxa de aquecimento e de oxidação (LANTTO, 2007).

As proteínas dos filamentos grossos e do disco $Z$ reagem diferentemente ao cozimento na faixa de 40 a $80^{\circ} \mathrm{C}$. A insolubilização da $\alpha-$ actina que é mais termo lábil ocorre a $50^{\circ} \mathrm{C}$, a da miosina a $55^{\circ} \mathrm{C}$, a da actina entre 70 e $80^{\circ} \mathrm{C}$, a da tropomiosina e da troponina a partir de $80^{\circ} \mathrm{C}$. As proteínas sarcoplasmáticas e a desnaturação do colágeno ocorrem a cerca de $65^{\circ} \mathrm{C}$. Durante o cozimento da carne há um incremento inicial da dureza entre 40 e $50^{\circ} \mathrm{C}$ devido ao inicio da desnaturação das proteínas miofibrilares. Em seguida, um incremento adicional ocorre entre 60 e $70^{\circ} \mathrm{C}$ por causa do encolhimento do colágeno intramuscular no endomísio. O terceiro incremento ocorre na faixa de 70 a $90^{\circ} \mathrm{C}$ quando ocorre o encolhimento e a desidratação da actomiosina. A estrutura muscular fica parcialmente destruída e durante $o$ 
cozimento e a micro estrutura natural do músculo é alterada (PALKA, DAUN, 1998).

A capacidade de reter água $(C R A)$ está relacionada com a microestrutura da carne e consiste na capacidade das carnes ou derivados reterem o suco natural ou água adicionada. Isto representa um fator tecnológico econômico com influência no rendimento, suculência, textura e sabor. Os músculos contém cerca de $75 \%$ de água na sua composição e a maior parte (até 67,5\%) está no sarcoplasma e até $7,5 \%$ no espaço intracelular. O restante está associado por pontes de hidrogênio às proteínas musculares superficiais que se mantêm em variadas condições. A CRA está relacionada com o pH e é afetada pela adição de sal o que faz as miofibrilas intumescerem aumentando seu volume e a capacidade de reter água. O sal também solubiliza as proteínas miofibrilares. A CRA depende também do valor de pH. Sem adição de sal, o ponto isoelétrico médio das proteínas no valor de $\mathrm{pH}$ de 5,0 situa-se a mais baixa capacidade de retenção de água (LANTTO, 2007).

Nos tecidos cárneos, encontra-se o colágeno que forma o principal tipo de fibra extracelular constituindo a proteína mais abundante do organismo animal. O colágeno está presente em grande quantidade nos tendões e ligamentos e existem fibras de colágeno em todos os tecidos e órgãos, incluindo os músculos. A glicina corresponde aproximadamente a um terço do conteúdo total de aminoácidos do colágeno e a prolina e hidroxiprolina correspondem a outra terça parte. A hidroxiprolina tem uma porcentagem constante no colágeno e como não aparece em quantidades significativas em outras proteínas é utilizada para determinar a porcentagem do colágeno nos tecidos. As fibras de colágeno são formadas por um arranjo regular de moléculas de tropocolágeno. São quase inextensíveis e individualmente são incolores, porém quando formam agregados apresentam a cor branca que caracteriza os tendões. As moléculas de colágeno apresentam ligações cruzadas entre si, o que se relaciona com sua relativa insolubilidade e resistência à tensão. $O$ tecido conjuntivo interno muscular contém cerca de $74 \%$ do total do colágeno muscular o qual difere do colágeno dos tendões nos seguintes aspectos: desenvolve uma contração térmica a cerca $64,5^{\circ} \mathrm{C}$ acima da temperatura que ocorre no tendão $\left(62^{\circ} \mathrm{C}\right)$; possui mais ligações 
cruzadas termo estáveis enquanto nos tendões predominam as termo lábeis; o encolhimento e a solubilização parcial do colágeno do endomísio bovino inicia-se a cerca de $62^{\circ} \mathrm{C}$ e completa-se aproximadamente a $70^{\circ} \mathrm{C}$ enquanto que no tecido conjuntivo do perimísio bovino é e necessário uma temperatura inicial de $70^{\circ} \mathrm{C}$ para o encolhimento. De uma forma geral, a desnaturação do colágeno muscular, resultando em encolhimento e solubilização, ocorre a temperaturas mais altas que a desnaturação das proteínas musculares (RANKEN, KILL, BAKER, 1993). Apesar de ser uma proteína de baixo valor biológico pela deficiência em lisina e triptofano tem grande utilidade funcional para retenção de água e agregação dos produtos cárneos. A desnaturação térmica é um processo endotérmico na qual a tríplice hélice do colágeno desenrola-se depois de uma energia de ativação crítica ser alcançada. De acordo com o tempo e a intensidade do aquecimento pode resultar numa transformação irreversível da estrutura natural helicoidal tripla em uma estrutura enovelada aleatória através da quebra das ligações de hidrogênio que estabilizam a hélice tripla. A Calorimetria Diferencial por Varredura (DSC) pode ser utilizada para correlacionar a exposição térmica com o grau de desnaturação (LANTTO, 2007). A análise calorimétrica permite medir a estabilidade das estruturas helicoidais das moléculas de colágeno relativas à transição colágeno a gelatina. A superposição de vários helicóides triplos produz as fibras de colágeno que são estabilizadas por meio de ligações cruzadas e formam uma estrutura de rede tridimensional. Esta estrutura é a responsável pela insolubilidade do colágeno, o qual através de uma hidrólise parcial é transformado em colágeno solúvel, resultando ou em gelatina, ou em colágeno hidrolisado. As propriedades físicas e funcionais da gelatina consistem na formação de gel, ligação de água, texturização, agente espessantante, formação e estabilização de emulsões, formação e estabilização de espumas, formação de filmes, adesão, coesão e proteção coloidal. A habilidade de formar gel é uma das mais importantes propriedades da gelatina. Para definir e avaliar as características do gel é utilizado o conceito de força de gel (gel strength) que é determinado pela aplicação de uma força correspondente ao peso em gramas necessário através de uma sonda com 12,7 mm de diâmetro na superfície de um gel para produzir uma 
deformação em forma de depressão de $4 \mathrm{~mm}$ de profundidade (POPPE, 1992).

A carne contém varias proteínas do tecido conjuntivo que tem a função de agrupar as células musculares (sarcômero) em feixes envoltos pelo endomísio e perimísio. Mudança nessas proteínas pelo aquecimento pode influenciar na qualidade do produto final, sendo o colágeno a mais importante dessas proteínas termo lábeis (PALKA, 1999).

O método tradicional de reestruturação de carnes utilizada nos embutidos cárneos cozidos está baseado na adição de gelificantes, emulsões e formação de géis devido à solubilização e extração das proteínas do interior da porção muscular pela adição de sal e fosfatos, seguido do embutimento no formato desejado e coagulação térmica. A tecnologia de presuntos conformados consiste na retenção de água e agregação dos músculos pela formação de íons e géis e obtenção da plasticidade de sua textura pelo massageamento para uma adequada moldagem através da prensagem mecânica durante o cozimento. As propriedades dos géis cárneos são principalmente dependentes da concentração do extrato cárneo. A gelatina pura em forma de pó pode ser adicionada no espaço onde foi retirado o osso para ligar os músculos. A utilização atual da k-carragena neste processo causa um incremento do complexo fator, a "força de gel" e a retenção de água. Os trabalhos realizados por Cheng-Jin et al. (2006) sugerem que as proteínas da carne solúveis em sal e não a carragena seriam responsáveis pela construção da estrutura da rede de gel tridimensional. Parece que a carragena não interage com a proteína da carne para participar da formação da rede uma vez que a viscoleslasticidade da rede mista proteína/carragena não difere da viscoelasticidade da rede de proteína pura. A carragena esta presente no espaço intersticial onde liga a água e pode formar fragmentos de gel em seguida ao resfriamento. A adição de 10\% de carragena à gelatina resulta na formação de um gel claro com ponto de solidificação reduzido (set point) com incremento na "força de gel" (gel strength) e elevação do ponto de fusão (POPPE, 1992). Atualmente tem havido um crescimento no emprego de reestruturação de carnes frescas a frio através da adesão com transglutaminase, fatores de coagulação de sangue de mamíferos, fibrina e 
alginato de sódio, possibilitando a conservação do produto simplesmente resfriado ou congelado e também cozido resfriado ou congelado.

Quanto ao método de reestruturação aplicado no corned beef, bem como em carnes cozidas compactadas (cooked frozen beef) destinadas ao porcionamento em cubos ou fatias de carne para compor refeições prontas, são utilizadas carnes previamente cozidas. Uma vez que as porções musculares são previamente cozidas a temperatura de $98^{\circ} \mathrm{C}$ durante 8 minutos em água sem adição de sais, já ocorreu a desnaturação e insolubilização das proteínas e gelificação do tecido conjuntivo colagenoso dos músculos, diferentemente do que ocorre no processo de reestruturação dos embutidos a partir de carnes cruas a temperaturas mais baixas onde ocorre a solubilização das proteínas miofibrilares, seguida de agregação, gelificação e formação de uma rede tridimensional de gel.

A operação de pré cozimento é necessária, uma vez que as perdas por cozimento, reduzem a umidade da carne possibilitando que a mesma seja compactada e enlatada e concentrando o teor de proteína de modo a atingir os valores mínimos de "conteúdo total de carne" (Total Meat Content, TMC) e de "conteúdo de carne magra" (Lean Meat Content, LMC), necessários para atender a legislação da União Européia (UE). Uma outra razão é a extração do caldo de carne para aproveitamento, juntamente com o colágeno solubilizado e o excesso de gordura fundida. $O$ objetivo do cozimento prévio dos tendões em água é promover a hidrolisação parcial do colágeno e gelificação parcial destes tecidos, para diminuir o esforço mecânico na redução do tamanho. A reestruturação deste tipo de produto inicia-se com a aplicação da pressão de compactação no enlatamento e a ligação (binding) dos pedaços pela adesão da gelatina proveniente dos tendões parcialmente gelificados e aponeuroses das porções musculares. Assim, o processo completo de gelificação dos tendões ocorrerá durante a etapa adicional de cozimento, que ocorre no processamento térmico, com o caldo liberado dos pedaços de músculo e eventual água adicionada na formulação, proporcionando a distribuição da gelatina formada entre os pedaços de músculo para efeito de adesão. 


\subsection{Propriedades de textura e Análise do Perfil de Textura (TPA)}

O tema textura corresponde às diferentes sensações físicas sendo, portanto melhor relacioná-la com as Propriedades de Textura, as quais correspondem a um grupo de propriedades relacionadas e não um simples parâmetro (BOURNE, 1982). Apesar de não haver uma definição satisfatória para textura pode-se considerar que a textura dos alimentos tem as seguintes características:

1. Consiste em um grupo de propriedades físicas decorrentes da estrutura dos alimentos.

2. Faz parte da subdivisão mecânica ou reológica das propriedades físicas, excluindo-se as propriedades físicas ópticas, elétricas, magnéticas, térmicas e de temperatura.

3. Consiste em um grupo de propriedades e não de uma propriedade isolada.

4. Podemos percebê-la principalmente pelo tato oral e manual.

5. Não está relacionada com a sensação química de sabor e odor.

6. Valores objetivos de textura podem ser obtidos pela medida da deformação (distância) e força (massa x aceleração) para vencer tal deformação ou tempo de ação da força.

A norma ISO 5492 (1982) define textura como um conjunto de propriedades reológicas e de estrutura (geométricas e de superfície) de um produto que são perceptíveis pelos receptores mecânicos, táteis e em alguns casos pelos visuais e auditivos (ALVARADO, AGUILERA, 2001).

Os ensaios fundamentais de medida física força e deformação são usados para medir as propriedades reológicas fundamentais dos alimentos tais como a viscosidade, o modulo de elasticidade e a relação de Poisson. Os ensaios utilizados como mais freqüência são os de relaxação e compressão seguida de descompressão. Normalmente tais propriedades são de difícil correlação com os parâmetros sensoriais nas condições usuais de consumo. Alguns dos principais parâmetros que podem ser obtidos nos testes fundamentais comumente utilizados são descritos a seguir e representados pelas Equações 5 a 9 , sendo os quatro primeiros relacionados com os 
alimentos sólidos (denominados elásticos) e o quinto com os alimentos fluidos (denominados Newtonianos).

1. Módulo de Elasticidade Linear ou Módulo de Young na compressão unidirecional:

$$
(E)=\frac{\text { tensão }}{\text { deformação }}=\frac{F / A}{\Delta / / I}
$$

2. Módulo de Elasticidade Transversal ou Modulo de Elasticidade no Cisalhamento:

$$
(G)=\frac{\text { tensão de cisalhamento }}{\text { deformação cisalhante }}=\frac{F / A}{\Delta / / I}
$$

2. Modulo de Elasticidade Volumétrica:

$$
(K)=\frac{\text { pressão hidrostática }}{\text { deformação volumétrica }}=\frac{F / A}{\Delta V / V}
$$

3. Relação de Poisson (para o caso de um sólido no formato de cilindro):

$$
\dot{\mu}=\frac{\text { deformação lateral }}{\text { deformação axial }}=\frac{\Delta d / d}{\Delta l / l}
$$

4. Viscosidade:

$$
\mu=\frac{\text { tensão de cisalhamento }}{\text { taxa de deformação }}=\frac{\sigma}{\dot{\gamma}}
$$

Os ensaios empíricos são os que medem parâmetros pouco definidos reologicamente, que podem ser facilmente expressados e seus resultados são bem característicos para o produto testado sob as condições experimentais utilizadas, como por exemplo, a penetrometria, a punção, a compressão e o corte (BOURNE, 1982).

Os métodos imitativos representados pela Análise do Perfil de Textura $(P T A)$, a qual constitui uma das técnicas instrumentais mais valorizadas para medir simultaneamente vários parâmetros de textura nos alimentos (ALVARADO, AGUILERA, 2001). Segundo Friedman et al. (1963) e Szczesniak et al. (1963) citados por Bourne (1982), um grupo no Centro 
Técnico Corporativo da General Foods foi precursor deste teste que tenta imitar as condições em que os alimentos são submetidos à mastigação na boca. Consiste em comprimir um pedaço de alimento do tamanho correspondente ao de uma mordida em dois ciclos num movimento recíproco que imita a ação da mandíbula resultando numa curva força-tempo que fornece vários parâmetros de textura bem correlacionados com a avaliação sensorial destes parâmetros. $O$ instrumento idealizado especialmente para este propósito é o Texturômetro GF (General Foods Texturometer). Uma curva típica do texturômetro GF é mostrada na Figura 1, através da qual diversos parâmetros de textura podem ser determinados. A altura do pico da força no $1^{\circ}$ ciclo de compressão foi definida como dureza 1 (hardness). A é o inicio da $1^{\underline{a}}$ compressão e B é o inicio da $2^{\underline{a}}$ compressão.

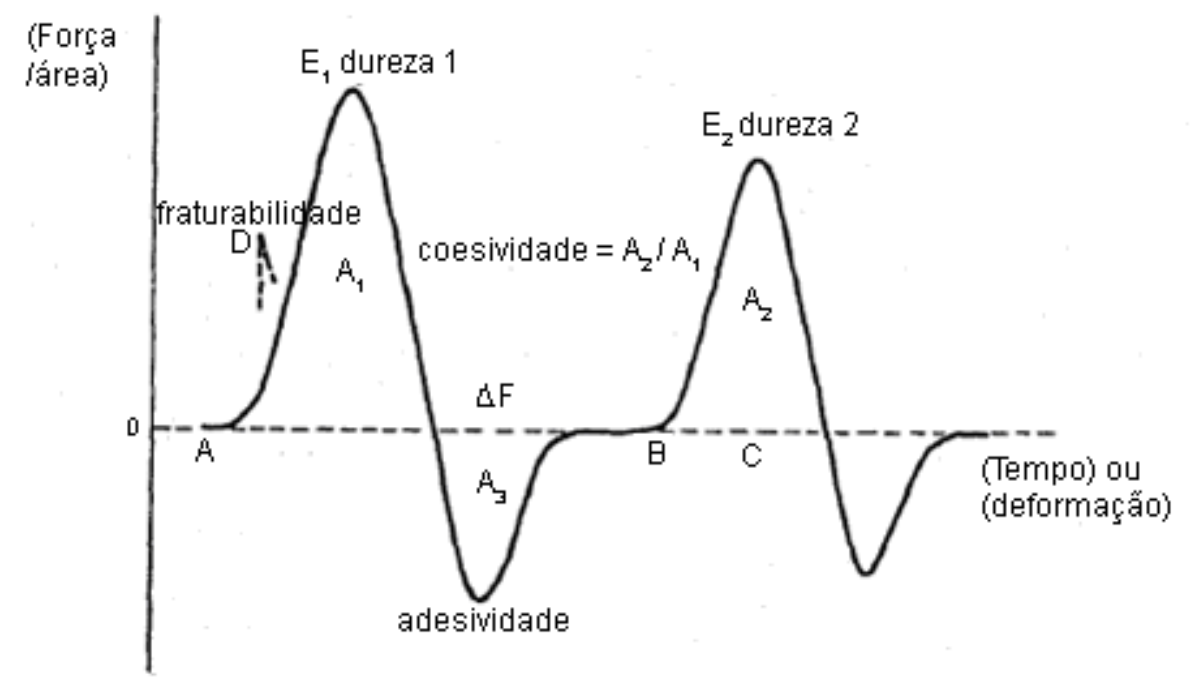

Figura 1. Curva típica do TPA no texturômetro GF (adaptada de BOURNE, 1982).

A fraturabilidade (fracturability) ou ponto de ruptura foi definida como a significativa interrupção da força na curva da primeira compressão (linha interrompida em $A_{1}$ ).

A relação das áreas positivas $\left(A_{2} / A_{1}\right)$ abaixo dos valores das forças respectivas a $1^{\underline{a}}$ compressão $\left(A_{1}\right)$ e a $2^{\underline{a}}$ compressão $\left(A_{2}\right)$ foi definida como coesividade (cohesiveness).

A área negativa da força da $1^{\underline{a}}$ compressão $\left(A_{3}\right)$ corresponde ao trabalho necessário para retirar a sonda da amostra e foi definida como adesividade (adhesiveness). 
A distância que a curva recupera sua altura durante o intervalo de tempo, ou seja, a velocidade de recuperação entre o fim da $1^{\underline{a}}$ compressão e o início da $2^{\mathrm{a}}$ compressão (BC) foi definido como elasticidade (springiness).

O parâmetro gomosidade (gumminess), ou pastosidade para alimentos semi-sólidos, é determinado como o produto da dureza pela coesividade. $\mathrm{O}$ trabalho ou energia de trituração do alimento, sensorialmente correspondente à 'mastigabilidade' (chewiness), é determinado como o produto da firmeza pela coesividade e elasticidade. A resiliência (resilience) corresponde à área sob a curva da $1^{\underline{a}}$ compressão $\left(A_{1}\right)$ menos a área correspondente da $2^{\underline{a}}$ compressão $\left(A_{2}\right)$.

Bourne (1982), seguindo a mesma interpretação de Friedman et al. (1963), mas usando o equipamento Instron adaptado para realizar o TPA, modificou o cálculo da coesividade medindo apenas a área abaixo da curva correspondente à compressão. Os picos no final de cada compressão, obtidos com o Instron são agudos e no GF arredondados.

Particularmente sobre a caracterização ou avaliação do perfil de textura instrumental do produto comercial corned beef não foram encontrados trabalhos na literatura. Shehata et al. (1994) realizou uma avaliação da firmeza de várias soluções de agentes gelificantes com a utilização de um teste empírico para textura, a penetrometria com cones $\left(25^{\circ} / 45 \mathrm{~g}\right.$ e $\left.40^{\circ} / 31,5 \mathrm{~g}\right)$ de acordo com a metodologia proposta por Klettner (1984), nas temperaturas de $20^{\circ} \mathrm{C}$ e $35^{\circ} \mathrm{C}$, indicando que quanto mais sólido o gel menor a distancia de penetração do cone. As soluções coloidais foram preparadas partindo da menor concentração que permitisse a formação de gel independentemente da sua firmeza. Com o incremento da concentração dos agentes gelificantes, a distancia de penetração do cone decresceu. Os valores mais baixos da distancia de penetração a $20^{\circ} \mathrm{C}$ foram $4,38 \mathrm{~mm}$, obtidos com as soluções de gel contendo $20 \%$ de gelatina (composição de $10 \%$ de tendões bovinos cozidos a $100^{\circ} \mathrm{C}$ por duas horas e moídos em disco com furos de $3 \mathrm{~mm}$ com $4,5 \%$ de gelatina bovina seca granulada) e $4,23 \mathrm{~mm}$ com agar-agar a $10 \%$. Os autores realizaram vários tratamentos de formulações com soluções em diferentes concentrações com diversos agentes gelificantes na preparação de corned beef acondicionado em latas de 200 gramas e esterilizadas a $121^{\circ} \mathrm{C}$ durante 60 minutos. Cada tratamento foi caracterizado quanto a sua 
composição centesimal e submetido à análise sensorial, através de um painel de degustadores treinados, e avaliados em escores em uma escala de cinco pontos segundo Jellinek (1981, citado por SHERATA et al. 1994). Os autores recomendaram, dentre os melhores tratamentos para uso industrial, o produto preparado com $60 \%$ de carne cozida moída, $10 \%$ de tendões cozidos e $4,5 \%$ de gelatina bovina seca. Este apresentou um teor de $24,37 \%$ de proteínas totais, baixo valor de cinzas $1,40 \%$ e escore de 11 pontos na avaliação sensorial de consistência, próximo aos valores alvo entre 14 e 16 pontos.

Dolata et al. (2001) realizou um estudo mais amplo, utilizando a análise instrumental do Perfil de Textura e teste fundamental para avaliação das propriedades de textura de um modelo de produto de carne enlatada, composto de carne suína picada, cozida e curada, com variados volumes de água adicionada na formulação e preparada de forma semelhante ao corned beef. $\mathrm{O}$ produto foi acondicionado em latas de aço cilíndricas e processado termicamente para sua pasteurização à temperatura de $72^{\circ} \mathrm{C}$ no centro de massa. Este modelo de produto cárneo foi somente pré-cozido, assemelhando-se ao corned beef ( $90 \%$ de carnes cozidas), antes do seu processamento térmico. Após o aquecimento as latas foram resfriadas à temperatura de 4 a $6^{\circ} \mathrm{C}$ durante 24 horas e em seguida os parâmetros de textura foram medidos em um Texturômetro Instron, modelo 1140. Concluiuse que as relações entre a maioria dos parâmetros de textura e os tratamentos foram lineares. Observou-se também que não houve um comportamento linear da coesividade e elasticidade. A elasticidade apresentou uma curva discreta em formato de arco com as extremidades para baixo e a coesividade também no formato de um arco mais curvo com as extremidades voltadas para cima, formando as duas curvas um contorno de concentração destes valores. Também houve uma relação linear dos parâmetros gomosidade e mastigabilidade com os demais parâmetros e tratamentos. Os parâmetros fundamentais tiveram entre si uma forte correlação estatisticamente significativa.

Palka e Daun (1998) estudaram as alterações histológicas e do Perfil de Textura em relação ao processamento do músculo semitendinoso bovino em várias temperaturas. Fatias do músculo de $17 \mathrm{~mm}$ de espessura foram 
cortadas no sentido perpendicular das fibras e embaladas a vácuo em pouches. Estes foram aquecidos nas temperaturas de 60, 70, 80, 90, 100 e $121^{\circ} \mathrm{C}$. Após o processamento, os pouches foram resfriados em água fria a $10^{\circ} \mathrm{C}$ e armazenadas a $6^{\circ} \mathrm{C}$ de um dia para outro. As amostras foram cortadas em cilindros de $13 \mathrm{~mm}$ de altura por $12 \mathrm{~mm}$ de diâmetro. Os parâmetros TPA foram medidos à temperatura ambiente usando um texturômetro TA-XT2. Os resultados mostraram que a temperatura interna teve efeito significativo nos parâmetros do TPA da amostra do músculo cozido. A elasticidade apresentou variação estatisticamente significativa nas faixas de 50 a $60^{\circ} \mathrm{C}$ e de 90 a $121^{\circ} \mathrm{C}$. A coesividade apresentou variação significativa na faixa de 90 a $121^{\circ} \mathrm{C}$ e os demais parâmetros na faixa 60 a $121^{\circ} \mathrm{C}$. A elasticidade foi o único parâmetro que teve variação estatisticamente significativa na temperatura de $50^{\circ} \mathrm{C}$ que parece ter sido afetada pela desnaturação da miosina e a-actina que ocorre nesta temperatura. Todos os parâmetros tiveram aumento com a elevação de temperatura (na fase ascendente de 70 a $80^{\circ} \mathrm{C}$ ), com exceção da elasticidade que diminuiu à temperatura de $60^{\circ} \mathrm{C}$. A coesividade alcançou o máximo a $70^{\circ} \mathrm{C}$, a elasticidade na faixa de 70 a $80^{\circ} \mathrm{C}$ e o trabalho de trituração (mastigabilidade) a $80^{\circ} \mathrm{C}$. A máxima dureza ocorreu na faixa de 80 a $100^{\circ} \mathrm{C}$.

Ali et al. (2005) avaliou o Perfil de Textura conforme a metodologia descrita por Bourne (1982) em filés de pescado (sardinha) processados termicamente em retortable pouches e latas de alumínio com vários valores de esterilização $\left(F_{0}\right)$ de 5,7 e 9 minutos. Os valores de cozimento $\left(C_{0}\right)$ obtidos nestes tratamentos foram significativamente menores nas embalagens pouches para valores de esterilização $\left(F_{0}\right)$ de 7 e 9 minutos. Os autores concluíram que para o mesmo valor de esterilização, o produto processado em retortable pouches apresentou valores de dureza, trabalho de trituração (mastigabilidade), coesividade e elasticidade mais altos que o produto processado em latas de alumínio.

Segundo a especificação de qualidade do corned beef da Campden \& Chorelywood Food Research Association - CCFRA (2001) são considerados padrões Continental Premium a graduação Campden $A^{*}$ e a graduação Campden A. A graduação Campden $A^{*}$ deverá apresentar um bloco de carne firme e suculento e proporcionar uma considerável sensação de mastigação 
de pedaços de carne. A textura deve ser fibrosa, mas livre de pedaços duros e difíceis de mastigar, porém não deve ser pastosa, graxenta ou borrachuda. Não deve ocorrer a quebra das fatias durante o corte ou manuseio.

A graduação Campden A deverá apresentar um bloco de carne razoavelmente firme e proporcionar uma considerável sensação de mastigação de pedaços de carne e textura fibrosa razoável, mas sem pedaços duros e difíceis de mastigar. Pode ser levemente pastosa, graxenta, ou borrachuda, entretanto sem quebras ou desintegração das fatias durante o corte e manuseio.

A graduação Campden B pode apresentar um bloco de carne levemente macio e proporcionar uma razoável sensação de mastigação de pedaços de carne. A textura poderá ser notadamente pastosa, graxenta ou borrachuda ou com pedaços difíceis de mastigar. Durante o fatiamento, um leve arrasto da lamina poderá quebrar as fatias ou desintegrar o bloco.

Quando o produto não satisfaz os requisitos da graduação B será considerado desclassificado. 


\section{MATERIAIS E MÉTODOS}

\subsection{Preparação do Corned Beef}

Foi utilizado como modelo base para o estudo o produto "carne bovina em conserva" (corned beef) enlatado com base na classificação padrão Campden A produzido na Fábrica de Conservas estabelecimento SIF 2023 situado em Votuporanga, São Paulo. O produto foi formulado conforme discriminado na Tabela 2, a partir de uma formulação industrial típica de um produto de carne bovino processado acondicionado em latas de folha de aço estanhada com o formato tronco trapezoidal, composto por retalhos de músculos $(78,22 \%)$ sem osso de carcaças e da cabeça (carne industrial)

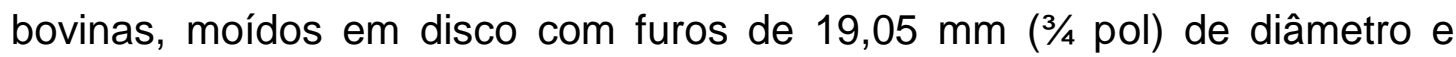
cozidas seus respectivos tendões $(5 \%)$ cozidos a $98{ }^{\circ} \mathrm{C}$ durante 8 minutos e moídos em disco com furos de $3,18 \mathrm{~mm}(1 / 8 \mathrm{pol})$ de diâmetro e a gordura (5\%) de cobertura moída em disco com furos de 3,18 mm de diâmetro, mescladas com água $(0,08 \%)$, sal (2,2\%), açúcar (1\%) e nitrito de sódio $(100 \mathrm{mg} / \mathrm{kg})$, ajustado para corresponder ao corned beef Campden grade $\mathrm{A}$, de acordo com especificações de qualidade estabelecidas pela Campden \& Chorelywood Food Research Association - CCFRA (2001).

As matérias primas foram obtidas frescas, embaladas em bolsas de polietileno, resfriadas e transportadas de 0 a $2^{\circ} \mathrm{C}$ e procedentes de frigoríficos sob Inspeção Federal, habilitados para fornecimento de matérias primas para a União Européia e Estados Unidos da América, sendo utilizadas no prazo máximo de 5 dias da data de embalagem. Os lotes das misturas foram produzidos com lotes de matérias primas do mesmo fornecedor e nas mesmas condições de processo. Cada lote foi proveniente de uma mesma batelada de mistura de carnes, enlatados nas mesmas condições e submetidos ao programa de processamento térmico.

Os lotes de mistura sofrem uma variação do padrão da composição devido às variações das matérias primas. A correção é efetuada adicionandose carne magra ou gordura para controlar o LMC. Nessas correções, o sal e o açúcar são ajustados de acordo com a fórmula base (Tabela 2). Entretanto as quantidades de tendão bovino cozido não foram ajustadas ocasionando uma 
variação de 3,72 a $5 \%$ na formulação. Embora o tecido conjuntivo presente nos recortes de carne ocorra em proporção natural, existe uma variação significativa devido ao tipo de refilamento (trimming) na produção dos cortes anatômicos que gera estes retalhos. Esta variação é decorrente dos tipos e padrões dos cortes produzidos pelo frigorífico, que estão sujeitos à demanda de mercado e não depende do controle do processo industrial na fábrica de conservas. Em contra partida ocorre uma significativa extração do colágeno solubilizado destes recortes que são cozidos continuamente em água a $98^{\circ} \mathrm{C}$, sem recirculação, durante 8 minutos, numa relação água/carne crua de 1,5 para 1. Este processo uniformiza e reduz a amplitude de variação do colágeno e da gordura na carne cozida. Diferente da gordura fundida no caldo que pode ser retirada, o colágeno extraído aparece de forma indesejável no caldo de carne concentrado (beef extract).

O controle da composição das bateladas dos lotes de mistura realizado na planta industrial, apresentada no Anexo 1, foi baseado nos resultados de análise por métodos rápidos de umidade e lipídeos e no cálculo da proteína por diferença. O Conteúdo Total de Carne (TMC) foi calculado somando-se o Conteúdo de Carne Magra ( $L M C$ ) ao teor de lipídeos. Estas análises foram baseadas nos métodos da Association of Official Analytical Chemists - AOAC e do Laboratório Nacional de Referência Animal LANARA (BRASIL, 1981; AOAC, 2009).

Tabela 2. Fórmula base dos lotes de corned beef, conforme padrão continental Premium classificação Campden A.

\begin{tabular}{ccccc}
\hline Ingrediente & $\begin{array}{c}\text { Quantidade } \\
(\mathrm{kg})\end{array}$ & $\begin{array}{c}\text { Rendimento } \\
\text { cru/cozido } \\
(\%)\end{array}$ & $\begin{array}{c}\text { Quantidade } \\
\text { por batelada } \\
(\mathrm{kg})\end{array}$ & $\begin{array}{c}\text { Fórmula } \\
\text { Base } \\
(\%)\end{array}$ \\
\hline carne industrial & 163,97 & 63,00 & 103,30 & 34,43 \\
recorte de desossa & 208,49 & 63,00 & 131,35 & 43,78 \\
tendão & 26,32 & 57,00 & 15,00 & 5,00 \\
recorte de desossa cru & 25,50 & & 25,50 & 8,50 \\
gordura crua & 15,00 & & 15,00 & 5,00 \\
sal & 6,60 & & 6,60 & 2,20 \\
açúcar & 3,00 & & 3,00 & 1,00 \\
água & 0,25 & & 0,25 & 0,08 \\
nitrito de sódio & 0,25 & & 0,03 & 0,01 \\
Total & 449,13 & 66,80 & 300,03 & 100,00 \\
\hline
\end{tabular}




\subsection{Enlatamento}

A massa de carne obtida foi embutida à temperatura variando entre 55 e $60^{\circ} \mathrm{C}$ através de enchedoras compactadoras mecânicas, fabricadas por Orengia \& Confort (Argentina) em latas tronco trapezoidais com massa entre 340 e 343 gramas de corned beef e fechadas a vácuo com 22 polegadas $\mathrm{Hg}$ com dupla recravação. Os lotes das misturas foram produzidos com lotes de matéria prima do mesmo fornecedor e nas mesmas condições de processo. Cada lote foi proveniente de uma mesma batelada de mistura de carnes, enlatado nas mesmas condições e posteriormente submetido ao programa de processamento térmico.

\subsection{Processamento Térmico Autoclave Horizontal e Penetração de Calor}

As latas foram processadas termicamente em autoclave cilíndrica horizontal com capacidade para três cestos, montadas pela própria indústria, com controle automatizado de temperatura e pressão. O sistema emprega a esterilização por vapor saturado e proporciona um elevado coeficiente convectivo do meio de aquecimento. As latas foram dispostas na posição vertical em cestos retangulares com paredes de chapa de aço perfurada (diâmetro dos furos de 1 pol.) dispostas em camadas intercaladas com separadores de polipropileno perfurados (diâmetro dos furos de 2 pol.). Foram realizados ensaios de penetração de calor para calcular o valor de esterilização aplicado nos lotes de processamento térmico. Os termopares foram fixados em cinco latas com o sensor no centro geométrico do bloco de massa cárnea do produto e outro no ambiente da autoclave. As latas foram colocadas nos cestos em cinco camadas diferentes conforme o esquema de localização na autoclave representado na Figura 2.

Foi definido o lote de processamento térmico como o correspondente às 147 latas da mesma camada da lata contendo o termopar para medição da temperatura no processo térmico. A carga total da autoclave foi composta por três cestos com nove camadas de 147 latas, totalizando 3.969 latas por processo térmico. Os dados de tempo e temperatura foram medidos por instrumento fabricado pela ELLAB A/S COPENHAGEN modelo CTF9008 versão $3.0 \mathrm{com}$ seis canais de leitura. Os dados foram computados em 
planilha eletrônica de cálculo obtendo-se a integração das taxas letais de todos os tempos e temperaturas até o final do processo pelo método proposto por Pataschnik (1953), correspondente a determinação do somatório das taxas letais em intervalos iguais de tempo dada pela Equação $4 \mathrm{a}$, reapresentada abaixo, para uma temperatura de referência de $121,1^{\circ} \mathrm{C}$. Foi utilizado o valor $\mathrm{z}$ de $10^{\circ} \mathrm{C}$ correspondente ao Clostridium sporogenes (RHA, 1967).

$$
F_{o}=\int_{0}^{t} \frac{1}{10^{\frac{121,1-T}{z}}} d t
$$

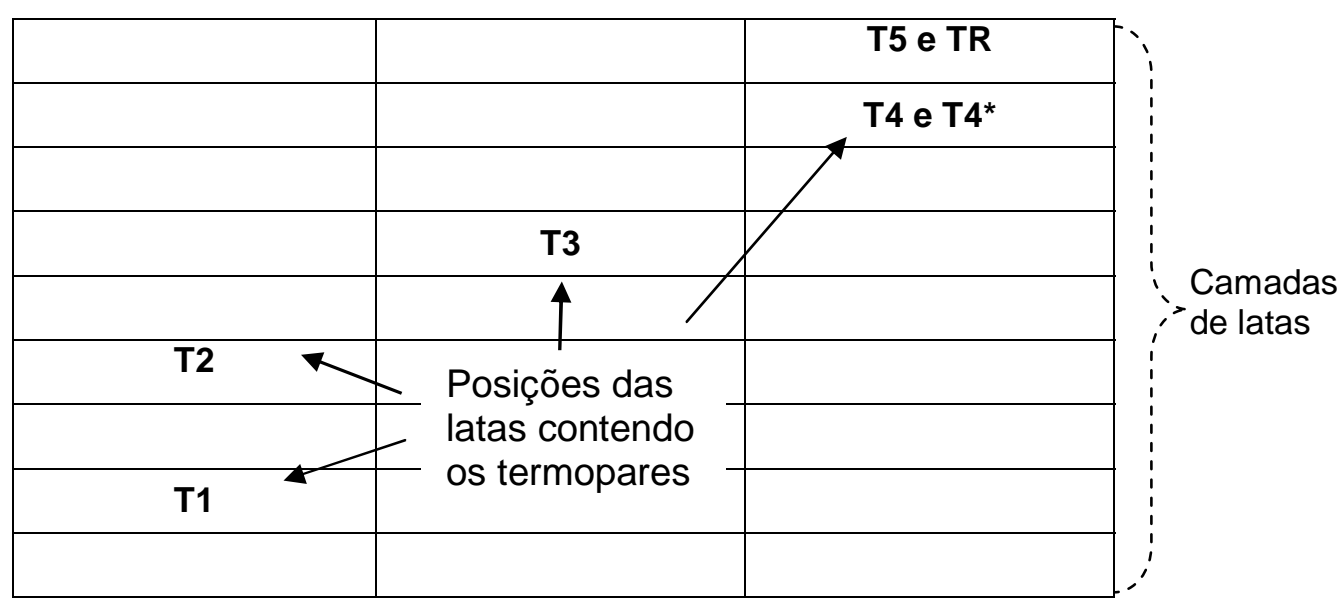

Figura 2 - Posicionamento das latas com os termopares no processamento térmico em autoclave para determinação dos valores de esterilização $F$ e posições das amostras retiradas para determinação do TPA e composição. A posição TR corresponde ao termopar para medição da temperatura da autoclave.

As cartas gráficas do controle automatizado $e$ as planilhas operacionais com as condições de cada processo térmico são apresentadas no Anexo 2. A Tabela 3 apresenta um resumo das condições operacionais empregadas no processamento térmico aplicado nos lotes de corned beef enlatado, em termos de tempo (variável) e temperatura da autoclave $\left(121^{\circ} \mathrm{C}\right)$ para a fase de aquecimento e tempo e temperatura da água de retorno da torre de resfriamento (fixos em 60 minutos e $35^{\circ} \mathrm{C}$ em média). Estes processos foram monitorados quanto à penetração de calor e as amostras de cada lote submetido ao processamento térmico foram retiradas da mesma 
camada onde estava posicionada a lata controle com o termopar para a medição da temperatura. Foram selecionados e monitorados 14 lotes de produção de corned beef nas condições descritas. Destes lotes foram retiradas 24 latas de produto correspondentes aos seus respectivos lotes de processamento térmico adjacentes às posições das latas com os termopares (Figura 2 e Tabela 3). Destas 24 latas, 6 amostras foram retiradas aleatoriamente para determinação do perfil de textura e da composição do corned beef.

\subsection{Análise do Perfil de Textura do Corned Beef}

As análises foram realizadas no Laboratório de Análise de Alimentos do Departamento de Apoio, Proteção e Saúde Animal da Faculdade de Medicina Veterinária da Universidade Estadual Paulista em Araçatuba (SP).

Para a determinação do Perfil de Textura do corned beef foi utilizado o texturômetro TA modelo XT2i da Micro Systems (Figura 3), com célula de carga de $25 \mathrm{~kg}$ e o Software Texture Expert fornecido pelo fabricante.

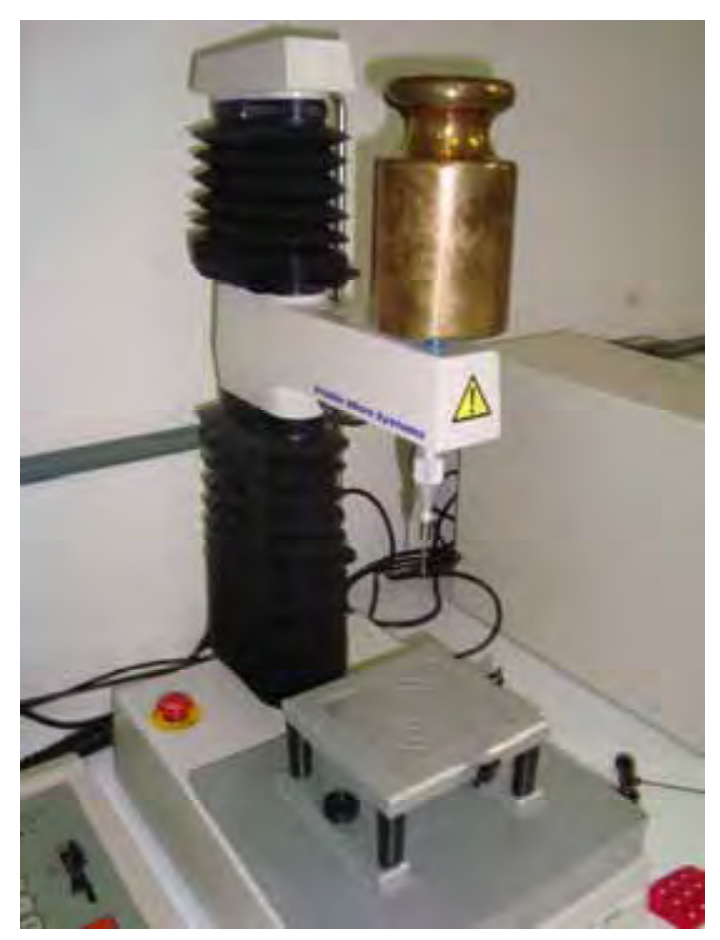

Figura 3. Texturômetro TA modelo XT2i da Micro Systems com célula de carga de $25 \mathrm{~kg}$. 


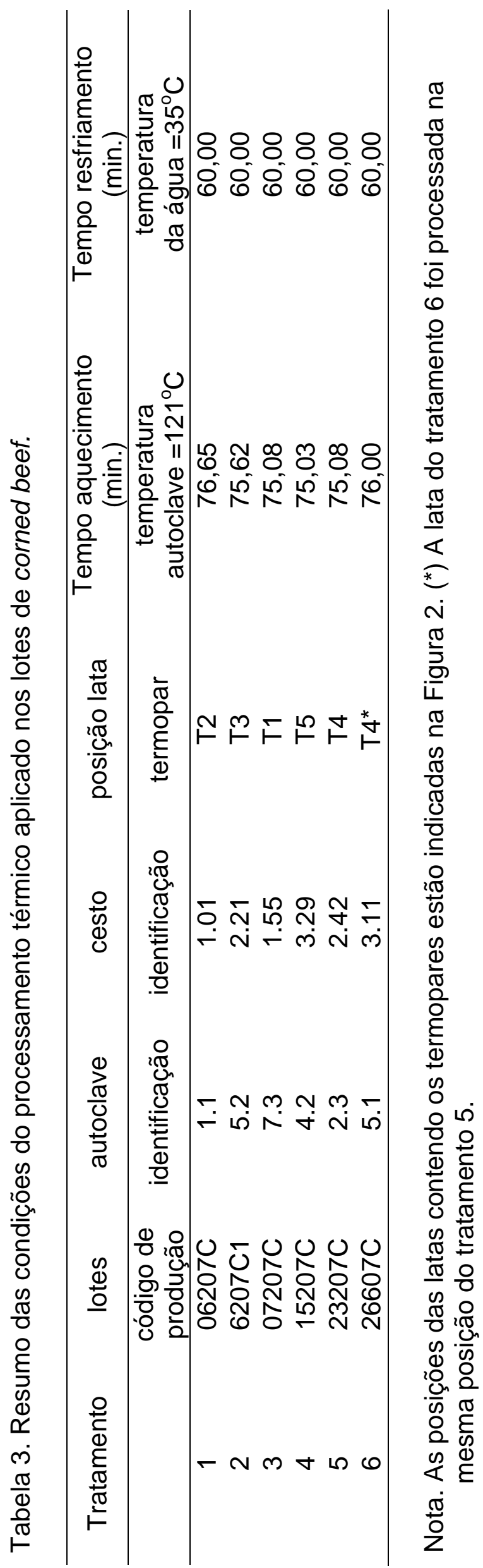


Com base na regulamentação da Associação Campden (CCFRA, 2001), que estabelece como $4^{\circ} \mathrm{C}$ a temperatura para a avaliação sensorial de textura, bem como do fatiamento manual, esta condição foi adotada no presente procedimento para a avaliação instrumental da textura. O Codex Alimentarius (CODEX ALIMENTARIUS COMMISSION, 1993) e o Regulamento Técnico de Identidade e Qualidade de Carne Bovina em Conserva (BRASIL, 2003) apenas estabelecem que o produto deva ser fatiável após o resfriamento. O Reino Unido é o mercado mais tradicional deste produto, sendo este consumido principalmente resfriado e fatiado, em sanduíches e saladas. Para isto, o consumidor costuma armazenar no refrigerador, principalmente no verão, a lata fechada antes de ser fatiada para o consumo. A Associação Campden (CCFRA, 2001) determina um resfriamento durante 12 horas a $4^{\circ} \mathrm{C}$ para a avaliação sensorial da textura e para o fatiamento manual. A textura é avaliada pelo fatiamento manual com uma faca fina em varias fatias de 3 a $5 \mathrm{~mm}$ e sensorialmente na boca.

Após o equipamento ter sido ligado, antes do início das análises, foi realizado as calibrações de rotina. A calibração da força foi realizada com um peso padrão de $5 \mathrm{~kg}$ posicionado sobre o cabeçote. A calibração da distância da ponta de prova a base da amostra foi feita posicionando-se a ponta de prova a uma distancia aproximada de $0,25 \mathrm{~mm}$ da base. $O$ disco do sensor de curso foi ajustado para a devida segurança do equipamento.

As amostras foram mantidas refrigeradas à temperatura de $0^{\circ} \mathrm{C}$ em estufa utilizada para análise da Demanda Biológica de Oxigênio (DBO) marca FANEM durante 12 horas, sempre na mesma posição na prateleira do meio. A temperatura interna na prateleira média foi medida utilizando-se um termômetro de mercúrio (TM) marca INCOTERM fixado na prateleira superior com o bulbo livre próximo às latas. Um outro termômetro digital (TD) da marca COX com o sensor do tipo termopar protegido por sonda em aço inoxidável de $15 \mathrm{~cm}$ e $2 \mathrm{~mm}$ de diâmetro foi utilizado para as medições de temperatura no bloco de corned beef. Devido a forte influência da temperatura na análise do perfil de textura, foi adotado um cuidadoso procedimento para condicionamento e análise do produto na temperatura especificada de $4^{\circ} \mathrm{C}$. Todos os termômetros utilizados foram previamente aferidos, colocando-os em contato (o bulbo do TM e a junção do termopar do 
TD) em banho com gelo, obtido de água deionizada congelada, em um recipiente isotérmico apresentando desvios de $0,0^{\circ} \mathrm{C}$ para o $\mathrm{TM}$ e $0,5^{\circ} \mathrm{C}$ para o TD.

Duas horas antes dos ensaios de textura a temperatura da estufa DBO foi ajustada para $4^{\circ} \mathrm{C}$. Após a estabilização a esta temperatura uma lata de amostra de corned beef era retirada da refrigeração e aberta pelo método tradicional (tear down), rasgando e enrolando a tira do semicorte da folha de flandres em volta do corpo da lata com a chave própria que acompanha a lata do produto. O bloco de carne era retirado cuidadosamente preservando o seu formato e sua integridade. Foram medidas as dimensões do bloco resfriado no mesmo formato da lata tronco trapezoidal: base $78 \times 60 \mathrm{~mm}$, topo $73 \times 50$ $\mathrm{mm}$ e altura $85 \mathrm{~mm}$. Foi colocado na superfície do bloco um gabarito de filme plástico PET no formato de um retângulo de $73 \times 50 \mathrm{~mm}$ com perfurações correspondentes a marcação dos nove pontos de penetração (Figuras 4 e 5 ). Elegeu-se a distância de penetração de $21 \mathrm{~mm}$, correspondente a $25 \%$ da altura do bloco, partindo do centro da área da superfície superior do bloco em direção ao centro de massa do bloco, correspondente à região de menor gradiente de temperatura entre o ponto central e a superfície do bloco, conforme mostrado na Figura 4.

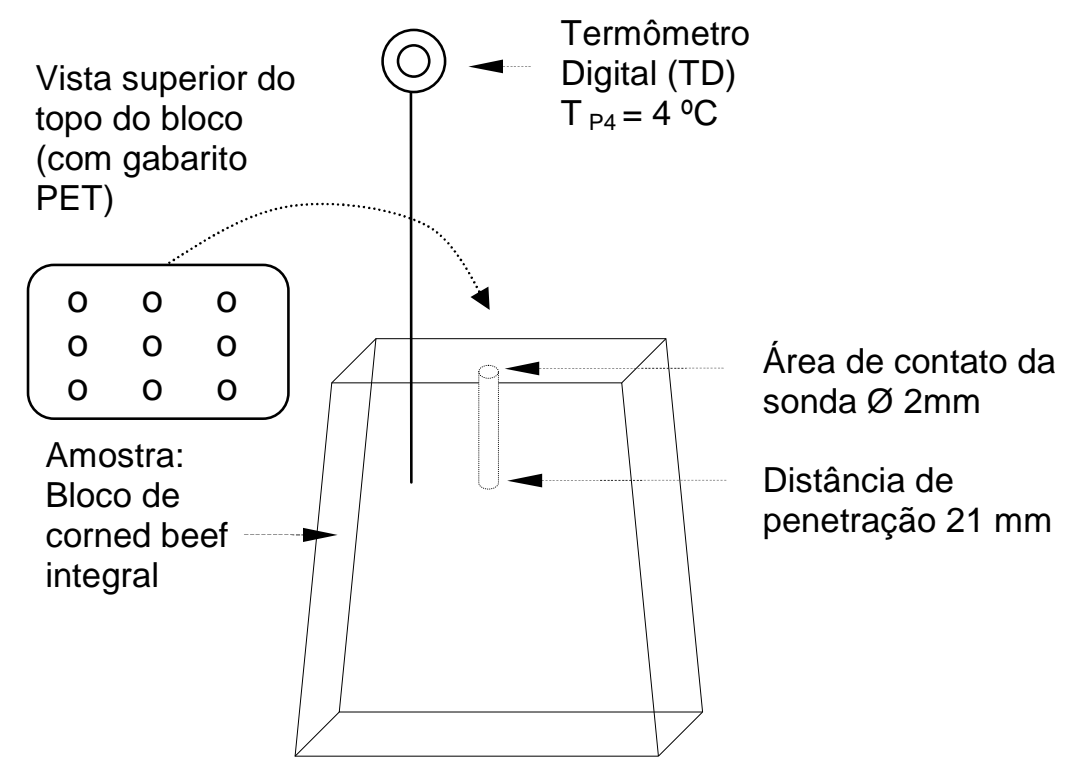

Figura 4. Esquema da localização dos pontos de penetração da sonda no bloco integral de corned beef com formato tronco trapezoidal. 
Um retângulo de filme de alumínio foi colocado sob a base do bloco e a sonda do termômetro digital introduzida cuidadosamente no ponto 4 a uma profundidade de $20 \mathrm{~mm}$ e distante $20 \mathrm{~mm}$ do centro geométrico para monitorar a temperatura da amostra. Em seguida, o bloco de corned beef foi embalado com o filme de alumínio para evitar a desidratação e a oxidação e mantido na $\mathrm{DBO}$ a $4^{\circ} \mathrm{C}$ até a atualização dos parâmetros do ensaio no texturômetro.

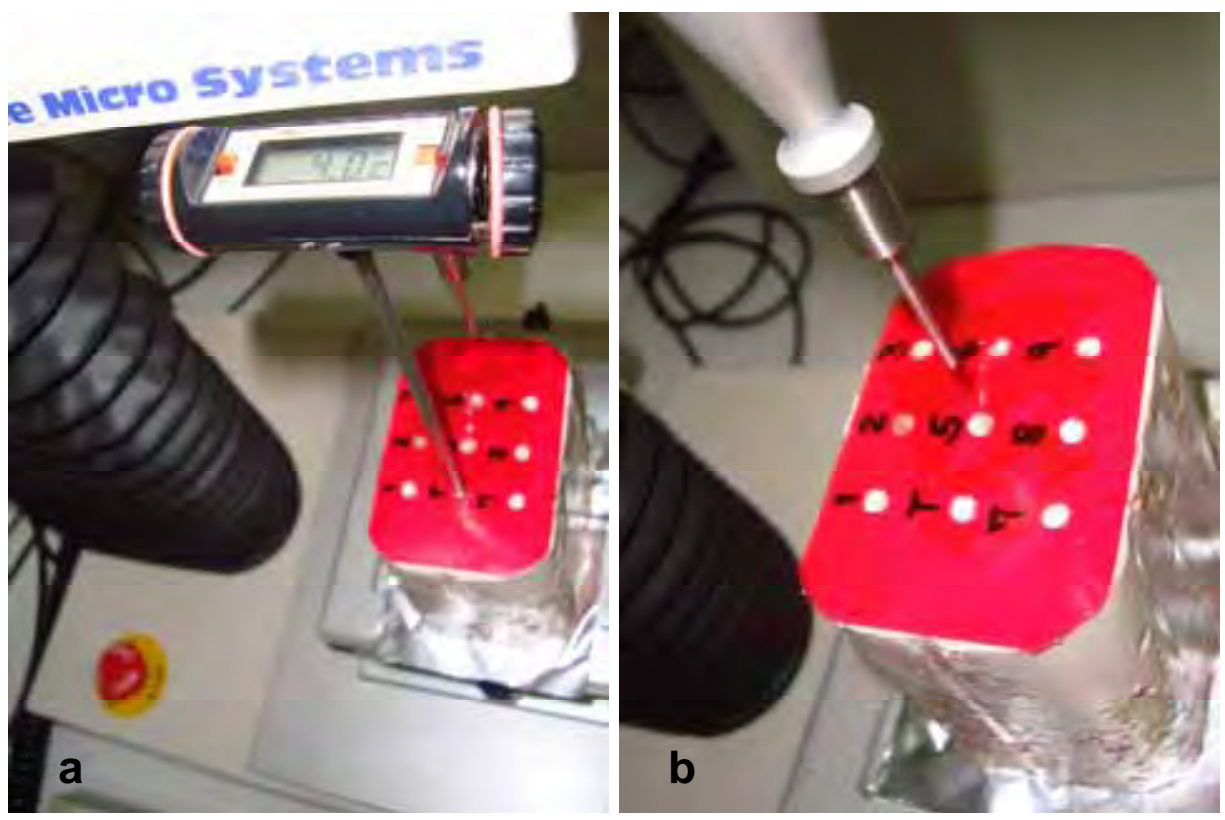

Figuras $5 \mathbf{a}$ e $\mathbf{5 b}$. Fotos mostrando a medição da temperatura (a) e pontos de penetração da ponta de prova do texturômetro (b) no bloco integral de corned beef.

No momento de início da análise de textura, a amostra era retirada da refrigeração (DBO), aberta a embalagem e posicionada imediatamente no centro da base do texturômetro e posicionado o ponto de compressão com o auxílio do gabarito em relação ao trajeto da ponta de prova. O termômetro digital era mantido inserido na amostra até a mesma atingir $4^{\circ} \mathrm{C}$. No exato momento que amostra atingisse a temperatura determinada $\left(4^{\circ} \mathrm{C}\right) \quad 0$ termômetro era retirado e acionado um comando via software para início da análise de textura.

Utilizou-se a ponta de prova $\mathrm{P} / 2$ cilíndrica de aço inoxidável com diâmetro de $2 \mathrm{~mm}$ (Figura 6a). Em testes preliminares, esta ponta de prova mostrou-se mais apropriada no sentido de evitar que os pedaços maiores de 
tecido muscular ou tecido conjuntivo fossem arrastados pela mesma, uma vez que 0 produto possui características de granulação bastante heterogênea. Esta sonda pode transpassar todos os pedaços dos tecidos presentes na composição do produto, cujas dimensões variam de 3,2 a 19,1 $\mathrm{mm}$. Outra razão desta escolha foi realizar a compressão numa pequena área equivalente com a região de medição de temperatura com os termopares nos ensaios de penetração de calor. Nos testes preliminares a ponta de prova de alumínio com $20 \mathrm{~mm}$ de diâmetro ocasionou deformação acentuada do formato do bloco e também arrastou os pedaços maiores de tecido através da matriz pastosa do produto.
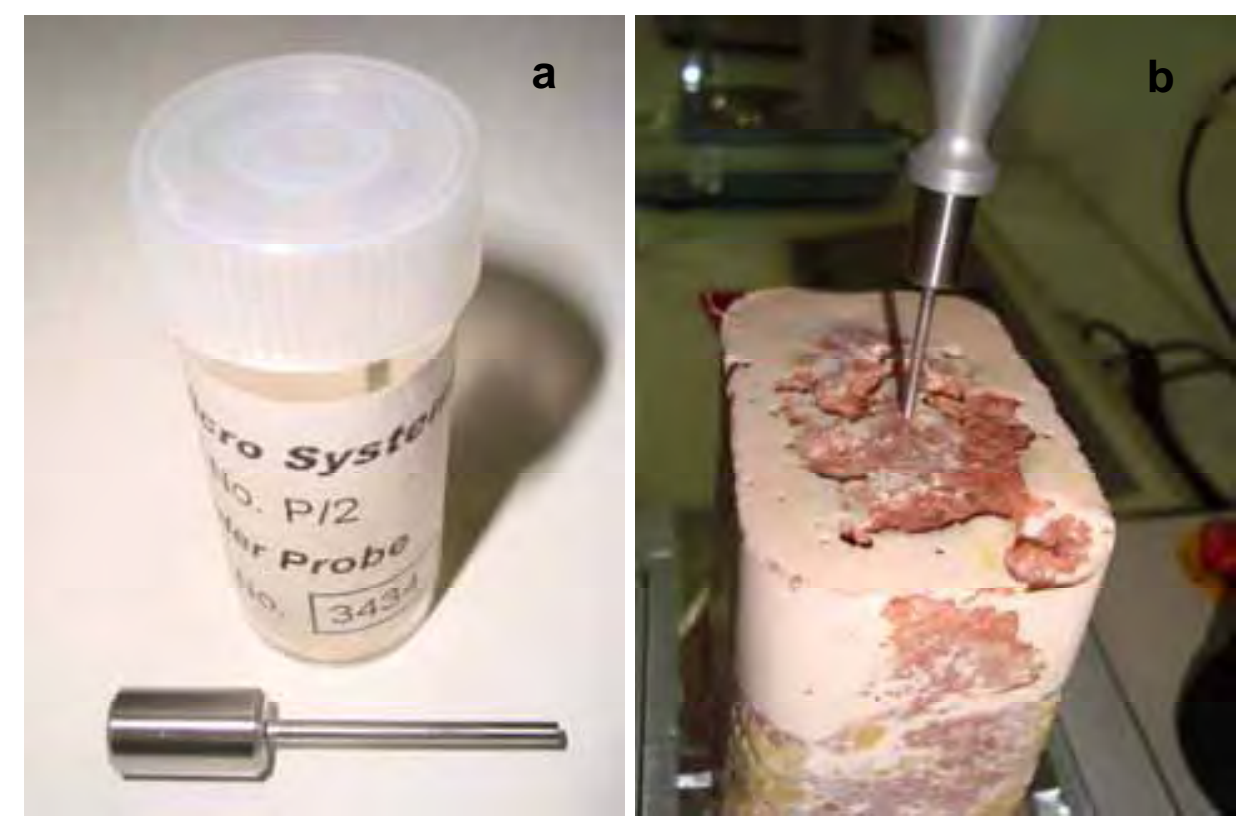

Figuras $6 \mathbf{a}$ e $6 \mathbf{b}$. Fotos mostrando a ponta de prova (a) e a penetração da sonda no bloco integral de corned beef (b).

Por outro lado, com a ponta de prova $\varnothing 2 \mathrm{~mm}$ devido à aderência ao produto, este pode ser levantado quando a sonda estava sendo retirada da amostra, após a primeira compressão, o que ocasionava uma mudança de posição da amostra, fazendo com que a segunda compressão atingisse uma posição diferente da primeira. Devido a este fato, utilizou-se o bloco inteiro de corned beef, conforme mostrado na Figura 4, evitando que a amostra se deslocasse de sua posição inicial durante os ensaios. Este procedimento também possibilitou correlacionar as medidas de textura (TPA) com a 
composição média da unidade de consumo, ou seja, o bloco inteiro do produto.

Como o produto mostrou-se muito adesivo na superfície lateral da ponta de prova, muitas vezes ocorrendo o deslocamento do bloco durante a retirada da sonda, foi utilizado rotineiramente nos ensaios o seguinte procedimento: limpeza da sonda com algodão hidrófilo e álcool etílico $98^{\circ} \mathrm{GL}$, seguida de lubrificação com azeite de oliva refinado.

Com base em testes preliminares, informações da literatura e do fabricante do equipamento determinou-se os parâmetros utilizados para a análise do perfil de textura: velocidade pré-teste $5 \mathrm{~mm} \cdot \mathrm{s}^{-1}$, velocidade do ensaio $1 \mathrm{~mm} \cdot \mathrm{s}^{-1}$, velocidade pós ensaio $5 \mathrm{~mm} \cdot \mathrm{s}^{-1}$, força para acionamento da compressão (gatilho) de $0 \mathrm{~N}$, altura da compressão $21 \mathrm{~mm}$ e tempo entre a primeira e a segunda compressão de 5 segundos. Os dados foram processados pelo software Texture Expert, versão 1.2 fornecido pelo fabricante do equipamento Stable Micro Systems.

Os dados de força versus tempo (ou deformação) da primeira e segunda compressão foram adquiridos digitalmente em intervalos de 0,005 s e gravados em computador, totalizando 15.800 dados para cada ensaio. Os dados originais são apresentados no Anexo 4. Para o cálculo dos parâmetros do perfil de textura, os seguintes procedimentos foram aplicados. A fraturabilidade correspondeu ao pico onde ocorre a interrupção da força na curva da primeira compressão expressa em N. A dureza corresponde ao pico mais alto na primeira compressão. A coesividade foi calculada pela relação da área abaixo da curva da primeira compressão e a área correspondente da segunda compressão. A adesividade foi calculada como a área correspondente aos valores de força negativa após a primeira compressão, correspondente ao trabalho necessário para retirar a sonda da amostra expressa em N.s. A elasticidade foi calculada pela relação da distância ou tempo entre o início e o final da segunda compressão e a distância ou tempo do início e final da primeira compressão. O parâmetro gomosidade foi determinado como o produto da dureza pela coesividade. A mastigabilidade foi determinada como o produto da firmeza pela coesividade e elasticidade. $A$ resiliência foi calculada como a diferença da área sob a curva da primeira 
compressão e a área correspondente da segunda compressão, expressa em N.S.

\subsection{Análise da Composição do Corned Beef}

O conteúdo integral de cada lata em que foi determinado o TPA de forma não destrutiva, na forma apresentada na Figura 7, foi colocado dentro de sacos de nylon poliéster e manualmente com o auxilio de um rolo o conteúdo foi pressionado para desagregar as fibras do corned beef e homogeneizado manualmente durante cerca de 5 minutos até apresentar uma aparência uniforme. Os pacotes foram selados a vácuo e identificados com a codificação do delineamento experimental apresentado na Tabela 4. As amostras foram mantidas a $-2,5^{\circ} \mathrm{C}$ durante todo o período, previamente à execução das análises.

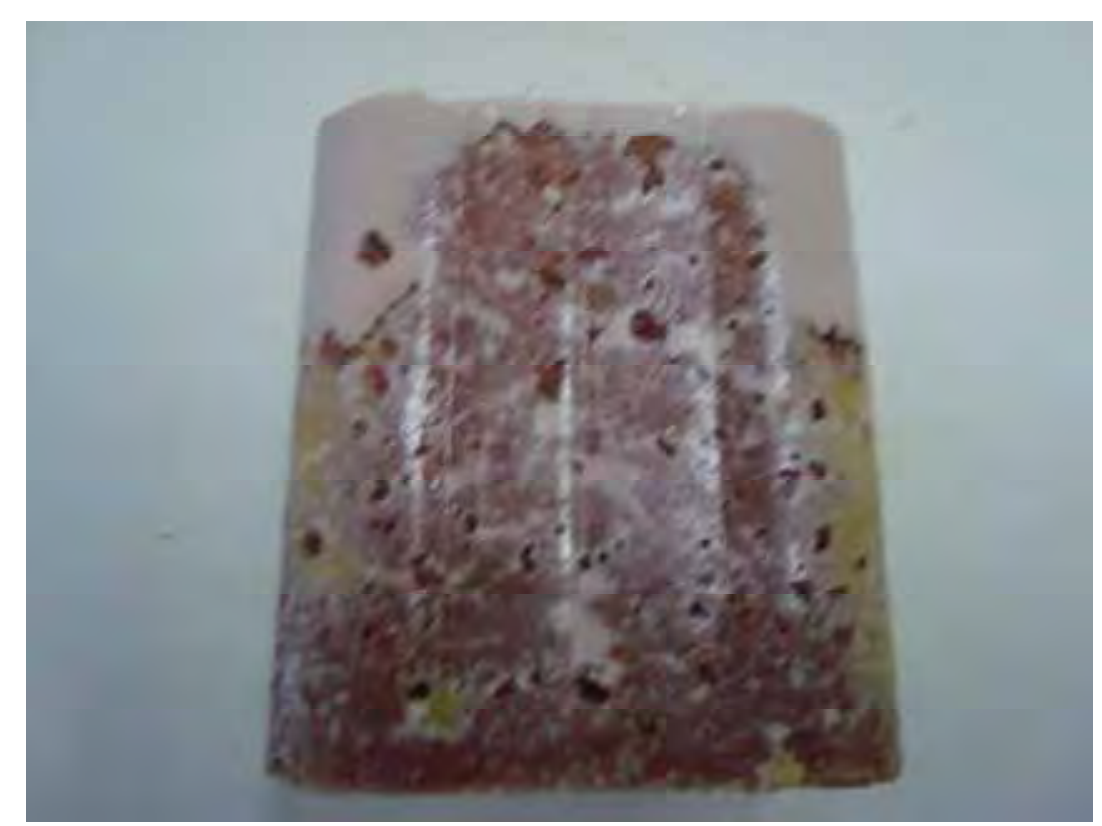

Figura 7. Amostra do bloco integral resfriado de corned beef após determinação do TPA destinado a análise da composição.

A metodologia utilizada nesta pesquisa para a determinação da composição do corned beef foi de acordo com os métodos oficiais de análise da Association of Official Analytical Chemists (AOAC, 2009). Foram retiradas duas alíquotas da massa homogeneizada para todas as análises de composição do corned beef que compreendeu umidade, lipídeos, cinzas, 
cloreto de sódio, proteína, hidroxiprolina, carboidratos por diferença e o cálculo da concentração da Proteína do Tecido Conjuntivo Colagenoso (CCTP), concentração da Proteína do Tecido Muscular (MPT) e Conteúdo de Carne Magra (LMC).

\subsubsection{Umidade}

A determinação da umidade foi feita por gravimetria baseada na perda de umidade a $105^{\circ} \mathrm{C}$. Foram pesadas $5 \mathrm{~g}$ das amo stras em cápsulas de porcelana previamente dessecadas e colocadas em uma estufa de dessecação marca OLIDEF modelo CZ durante 3 horas. As amostras foram resfriadas naturalmente no dessecador e pesadas. Foram novamente colocadas na estufa durante dois períodos de uma hora e novamente pesadas até obtenção do peso constante da amostra seca. Após a pesagem final das amostras secas para determinação das perdas de umidade estas foram mantidas com sua identificação no dessecador para posterior extração de lipídios. A umidade foi calculada dividindo-se a diferença de peso entre a amostra úmida e a amostra seca pelo peso da amostra úmida e multiplicada por 100 .

\subsubsection{Cinzas}

A determinação de cinzas ou resíduo mineral fixo foi realizada por gravimetria fundamentada na perda de peso do produto incinerado a $550^{\circ} \mathrm{C}$ para destruição da matéria orgânica. As amostras foram pesadas $(5 \mathrm{~g})$ em cadinhos de porcelana e dessecadas da mesma forma usada na determinação da umidade. As amostras dessecadas foram carbonizadas sobre uma placa aquecedora marca FANEM até cessar o desprendimento de fumaça e em seguida incineradas numa mufla marca EDG modelo F18001P a $550^{\circ} \mathrm{C}$ por um período de 4 horas até a obtenção de cinzas claras. Os cadinhos foram resfriados naturalmente no dessecador e pesados. Calculouse o percentual de cinzas dividindo-se o peso das cinzas pelo peso da amostra úmida e multiplicando por 100. Estas amostras foram mantidas identificadas no dessecador para posterior determinação de cloretos. 


\subsubsection{Proteína}

A proteína total do corned beef foi analisada pela determinação do nitrogênio total segundo o método Kjeldahl, baseado no deslocamento do nitrogênio através da digestão da amostra e sua transformação em sal de amônio. Em meio alcalino e por aquecimento, $\mathrm{O} \mathrm{NH}_{3}$ é volatilizado e condensado reagindo com o ácido bórico. A quantidade de amônia que reagiu com o acido bórico é determinada por titulação com ácido clorídrico da solução formada (borato de amônio). Foi pesada 1 grama da amostra de corned beef diretamente nos tubos de digestão micro-Kjeldahl e adicionados $7 \mathrm{ml}$ de ácido sulfúrico e pequena quantidade do catalisador Merck. Os tubos foram colocados num bloco para digestão marca TECNAL modelo TE- 044, previamente aquecido a $200^{\circ} \mathrm{C}$, e elevada à temperatura de $50 \mathrm{em} 50^{\circ} \mathrm{C}$ até atingir a temperatura constante de $400^{\circ} \mathrm{C}$, sendo mantidos a esta temperatura durante 4 horas até a obtenção de um líquido límpido e transparente verde claro. Após o resfriamento natural da solução adicionou-se $10 \mathrm{ml}$ de água destilada e 2 gotas do indicador fenolftaleína e o tubo foi acoplado no destilador de nitrogênio micro Kjeldahl marca TECNAL modelo TE 036/1. A solução foi neutralizada adicionando-se uma solução de hidróxido de sódio $50 \%$ até coloração violeta e em seguida foi iniciado o aquecimento. $O$ condensado formado foi coletado num frasco de Erlenmeyer de $250 \mathrm{ml}$ acoplado ao equipamento contendo uma solução de $20 \mathrm{ml}$ de ácido bórico a $4 \%$ e 4 gotas do indicador misto de Tashiro. A temperatura e a vazão da água do resfriamento do condensador foram controladas para evitar o aquecimento do condensado. A destilação foi interrompida quando cessou a reação alcalina e obteve-se um volume de $100 \mathrm{ml}$ da solução formada. Esta foi titulada com uma solução padronizada de ácido clorídrico $0,1 \mathrm{~N}$, com fator conhecido, até o ponto de viragem para a cor amarela e anotado o volume de $\mathrm{HCl}$ gasto. O teor de proteína total da amostra foi calculado utilizando a Equação 11, aqui denominada Proteína Total da Carne (TMP).

$$
\mathrm{TMP}=\frac{\mathrm{V} \cdot \mathrm{N} \cdot \mathrm{f} \cdot 0,014 \cdot 100}{\mathrm{p}} \cdot \mathrm{F}
$$

onde, $\mathrm{V}=\mathrm{ml}$ solução de ácido clorídrico $0,1 \mathrm{~N}$ gastos na titulação; 
$\mathrm{N}=0,1 \mathrm{~N}$; normalidade teórica da solução de ácido clorídrico;

$\mathrm{f}=1,052$; fator de correção da solução de ácido clorídrico $0,1 \mathrm{~N}$;

$\mathrm{p}=$ massa da amostra em gramas;

$F=6,25$; fator de conversão do $\mathrm{N}$ para proteína para carnes e derivados.

\subsubsection{Lipídeos}

A determinação dos lipídios no corned beef foi realizada pela extração dos lipídeos com o solvente orgânico n-hexano e determinados por gravimetria. A amostra seca oriunda da determinação da umidade foi retirada da cápsula de porcelana com uma camada de algodão desengordurado, envolvida na mesma e introduzida no cartucho de celulose para extração. Foi utilizado o aparelho de extração Soxhlet marca TECNAL modelo TE-04. Os copos de vidro destinados ao solvente e a amostra (reboilers) foram previamente aquecidos em estufa a $105{ }^{\circ} \mathrm{C}$ durante uma hora, resfriados em dessecador, identificados e pesados. O extrator foi previamente aquecido a $120^{\circ} \mathrm{C}$ e os cartuchos foram colocados no interior dos reboilers mergulhados em $100 \mathrm{ml}$ de solvente e cuidadosamente ajustados ao condensador do extrator. A temperatura do extrator foi regulada para $140^{\circ} \mathrm{C}$ e iniciado o processo de extração durante 8 horas. Após a extração, foi bloqueado o fluxo do solvente condensado para o reboiler de modo que quase todo solvente contido no reboiler fosse evaporado e recuperado na parte inferior do condensador. Após a evaporação quase total do solvente no reboiler o mesmo foi colocado na estufa a $102^{\circ} \mathrm{C}$ durante uma hora. Em seguida o reboiler foi resfriado naturalmente em dessecador e pesado. Repetiu-se o procedimento até o reboiler contendo a gordura extraída apresentar peso constante. $\mathrm{O}$ cálculo do teor de lipídios na amostra foi feito dividindo-se o peso da gordura extraída contida no reboiler pelo peso da amostra úmida inicial utilizada para determinação da umidade.

\subsubsection{Cloreto de sódio}

A determinação de cloreto de sódio nas amostras foi realizada pela técnica titulométria fundamentada na precipitação dos cloretos sob a forma 
de cloreto de prata, em pH 8,3 e na presença de cromato de potássio como indicador. No final da reação forma-se um precipitado como cromato de potássio vermelho-tijolo. As cinzas das respectivas amostras foram transferidas em água destilada $\left(80^{\circ} \mathrm{C}\right)$ e filtrada para um balão volumétrico de $200 \mathrm{ml}$ completando-se o volume com água destilada. Para diluição, $5 \mathrm{ml}$ do volume filtrado foram completados para $100 \mathrm{ml}$ em balão volumétrico com água destilada. A solução diluída foi transferida para um frasco de Erlenmeyer de $250 \mathrm{ml}$ e adicionado 5 gotas da solução de indicador cromato de potássio a $10 \%$. Esta solução foi titulada com uma solução de nitrato de prata $0,1 \mathrm{~N}$ até o aparecimento da cor amarelo-avermelhado e anotado o volume gasto. Para o cálculo do percentual de cloreto de sódio foi empregada a Equação 12.

$$
\% \text { cloretos }=\frac{V \times f \times 0,584 \times 40}{p}
$$

onde,

$\mathrm{V}=$ volume de $\mathrm{AgNO}_{3}$ 0,1 $\mathrm{N}$ gasto na titulação $(\mathrm{ml})$;

$\mathrm{f}=$ fator de correção da solução de $\mathrm{AgNO}_{3} 0,1 \mathrm{~N}=1$;

$\mathrm{p}=$ peso da amostra úmida para determinação de cinzas $(\mathrm{g})$;

40 = fator de diluição $(5: 200 \mathrm{ml})$.

\subsubsection{Hidroxiprolina e Proteína do Tecido Conjuntivo Colagenoso (CCTP)}

A concentração do CCTP no corned beef foi determinada pela análise espectrofotométrica quantitativa do aminoácido hidroxiprolina como medida das proteínas colagênicas. Esta técnica é considerada o método de referência para esta determinação em carnes e derivados, com os valores expressos em \% massa/massa. Considerou-se que o tecido conjuntivo colagenoso contém $12,5 \%$ de hidroxiprolina, quando se usa o fator 6,25 na conversão do nitrogênio em proteína. A técnica consiste na hidrólise das amostras com ácido sulfúrico, filtração do hidrolisado e diluição. A hidroxiprolina é oxidada com a cloramina $T$ e adiciona-se 4dimetilaminobenzaldeido para desenvolver uma cor vermelha púrpura, que pode ser medida em espectrofotômetro a $558 \mathrm{~nm}$. 
Foram pesadas $4 \mathrm{~g}$ da amostra depositando-a diretamente em frasco Erlenmeyer identificado de $250 \mathrm{ml}$ e adicionados $30 \mathrm{ml}$ de ácido sulfúrico. Os frascos foram tampados com placas de Petri com diâmetro apropriado e deixados em repouso durante 16 horas em estufa de dessecação à temperatura de $105{ }^{\circ} \mathrm{C}$ para proceder a hidrólise. $\mathrm{O}$ hidrolisado ainda quente foi transferido quantitativamente com água destilada para um balão volumétrico e completado o seu volume para $500 \mathrm{ml}$ com água destilada. $\mathrm{O}$ conteúdo foi agitado e em seguida filtrado em papel filtro em frascos de Erlenmeyer de $100 \mathrm{ml}$. Foram pipetados $5 \mathrm{ml}$ do filtrado e diluídos em água destilada para o volume de $100 \mathrm{ml}$ em balão volumétrico, determinado em função da concentração de hidroxiprolina presente.

Foram pipetados $2 \mathrm{ml}$ da solução diluída em dois tubos de ensaio identificados e adicionado $1 \mathrm{ml}$ da solução oxidante de Cloramina T. Foi preparado um par de tubos com $2 \mathrm{ml}$ de água destilada e Cloramina T denominados brancos. Os tubos foram tampados com rolhas plásticas, agitados e deixados em repouso durante 20 minutos à temperatura ambiente. Em seguida, foram adicionados aos tubos $1 \mathrm{ml}$ da solução corante de 4dimetilaminobenzaldeido, fechados e agitados. Os tubos foram dispostos em estantes na posição vertical, imediatamente imersos em banho térmico marca FANEM modelo 1102 previamente regulado a temperatura de $60^{\circ} \mathrm{C} \pm 0,1^{\circ} \mathrm{C}$, mantidos exatamente por 15 minutos. Completado o tempo de aquecimento a estante com os tubos foi mergulhada numa bandeja com água fria corrente durante 3 minutos. Foi pipetado o conteúdo de cada tubo e colocado na cubeta de vidro com caminho óptico de $1 \mathrm{~cm}$. A absorbância foi medida a 558 $\mathrm{nm} \pm 2 \mathrm{~nm}$ em espectrofotômetro marca HITACHI U- 1900 UV/VIS modelo 3JO-0003. Foi preparada previamente uma solução de concentração padrão de $60 \mathrm{mg}$ de hidroxiprolina diluída em $100 \mathrm{ml}$ de água destilada (600 $\mu \mathrm{g} / \mathrm{ml})$ denominada solução estoque e mantida sob refrigeração a $4^{\circ} \mathrm{C}$. A partir desta solução foram preparadas soluções com concentrações de 0,6 $\mu \mathrm{g} / \mathrm{ml}, 1,2$ $\mu \mathrm{g} / \mathrm{ml}, 1,8 \mu \mathrm{g} / \mathrm{ml}$ e 2,4 $\mu \mathrm{g} / \mathrm{ml}$ para cada série de análises. Em cada uma destas soluções foi aplicado o mesmo procedimento descrito anteriormente. Antes de iniciar as análises das amostras do corned beef foi construída a curva de calibração do espectrofotômetro através da medição da absorbância das soluções com concentrações conhecidas de hidroxiprolina a $558 \mathrm{~nm} \pm 2$ 
nm. Após a análise de regressão linear das curvas de calibração foi realizada a medida da absorbância das amostras e o valor convertido em concentração

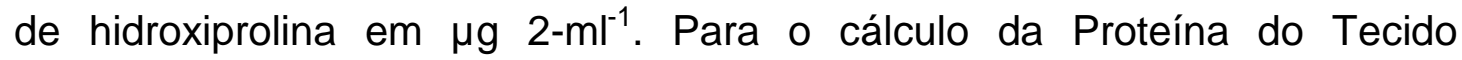
Conjuntivo Colagenoso (CCTP) foi utilizada a Equação 13, e o resultado expresso em g $100 \mathrm{~g}^{-1}$.

$$
C C T P=\frac{h \times 2,5}{m \times V} \times 8
$$

onde,

$\mathrm{h}=$ hidroxiprolina em $\mu \mathrm{g} 2-\mathrm{ml}^{-1}$;

$\mathrm{m}=$ massa da amostra em gramas $(\mathrm{g})$;

$\mathrm{V}=$ volume do filtrado utilizado para diluição $(5 \mathrm{ml}: 100 \mathrm{ml})=5 \mathrm{ml}$.

\subsubsection{Proteína do Tecido Muscular (MTP)}

Neste trabalho foi adotada uma simplificação para o cálculo do MTP, considerando que este consiste na Proteína Total da Carne (TMP) menos a proteína do tecido conjuntivo, incluindo as proteínas sarcoplasmáticas e miofibrilares, como também as frações de nitrogênio não protéico. Entretanto os valores de MTP calculados correspondem à Proteína Total da Carne subtraindo-se apenas a Proteína do Tecido Conjuntivo Colagenoso presentes no corned beef, desconsiderando-se, portanto, as demais proteínas do tecido conjuntivo das fibras elásticas e reticulares (Equação 14). A conversão da CCTP (colágeno) para tecido conjuntivo pode ser calculada utilizando-se o fator de 4,625 adotado pelo Liaison Centre for the Meat Processing Industry in Europe (CLITRAVI, 2002).

$$
M T P=(T M P)-(C C T P)
$$

A regulamentação deste produto pelo principal mercado consumidor 0 Reino Unido (CCFRA, 2001), estabelece que o produto deva ter no mínimo $120 \%$ do equivalente ao "Conteúdo Total de Carne" (Total Meat Content, TMC) e $96 \%$ mínimo do equivalente ao Conteúdo de Carne Magra (Lean 
Meat Content, $L M C$ ). Estes valores são correspondentes na prática ao conteúdo equivalente em carne crua que foi cozida e adicionada na formulação. $O L M C$ foi calculado a partir do valor do percentual de nitrogênio total da carne dividido pelo fator Stubbs \& More 3,65 (AOAC, 2009) e o $T M C$ pela soma do $L M C$ com o teor de lipídeos. Estes valores são expressos em percentual do equivalente à carne crua (ZÚKAL, 2009).

\subsection{Análise de dados e delineamento experimental}

Para as análises estatísticas foi utilizado o software STATISTICA versão 9. As condições para a análise estatística com um delineamento experimental em blocos casualizado $(D B C)$ foram estabelecidas a partir da seleção dos 14 lotes de produção preparados nas mesmas condições (homogeneidade), dos quais foram retiradas 24 latas (amostras) do produto de diferentes lotes de processamento térmico. Estas amostras foram denominadas lotes e identificadas de acordo com o tratamento térmico recebido e a posição da lata na autoclave. Desta amostragem foram retiradas 6 latas de forma aleatória, que foram eleitas como parcelas experimentais, para determinação do TPA e da composição do corned beef. Cada parcela experimental representa um respectivo lote homogêneo em relação às condições de processamento térmico e composição. As posições destas latas na autoclave e das latas vizinhas com termopares para medição da temperatura no centro do produto são mostradas no esquema da Figura 2.

Cada parcela experimental corresponde a um tratamento com o fator $F_{0}$ (valor de esterilização) calculado. No conteúdo integral de cada lata foram determinados os parâmetros de TPA em oito pontos diferentes do produto de forma não destrutiva. O conteúdo total foi em seguida homogeneizado e retiradas alíquotas duplicadas da massa homogeneizada para análise da composição. Para relacionar os parâmetros de TPA com a composição foi considerado a média do resultado analítico das duplicatas das amostras de cada tratamento de $F_{0}$.

O delineamento experimental compreendeu então 6 tratamentos $\left(F_{0}\right)$ com 8 repetições (blocos) do PTA em diferentes posições no bloco do 
produto e que foram relacionados com os resultados da composição média do mesmo bloco do produto. Este delineamento e a codificação das amostras estão apresentados de forma detalhada na Tabela 4.

Nos valores de cada parâmetro de TPA obtidos nos tratamentos, foi aplicado o teste $t$ de Student $(P<0,05)$ para verificar se os resultados das oito observações apresentavam distribuição normal. Em seguida foi realizado o teste $F$ de Snedecor nos resultados dos tratamentos para comparar as estimativas de variâncias ao nível de significância $\alpha$ de $5 \%$ ou seja, $95 \%$ de probabilidade $(p<0,05)$. $A$ análise de variância foi aplicada para verificar se existiam diferenças entre as médias dos parâmetros de TPA dos 6 tratamentos $\left(F_{0}\right)$ e entre os parâmetros de TPA determinados nos 8 pontos (blocos) em diferentes posições no produto. Foi calculado o contraste entre as médias de cada tratamento para cada parâmetro determinado e aplicado o teste de Tukey no nível de $5 \%$ para verificar diferenças entre as médias dos tratamentos e classificá-las em grupos homogêneos.

Para verificar a correlação entre a intensidade dos tratamentos térmicos, com base nos valores de esterilização $F_{0}$, as médias de composição, com base em CCTP, MTP e LMC e as médias dos parâmetros de TPA, foram calculados os coeficientes de correlação de Pearson. Foi aplicada a ANOVA no nível de confiança de $95 \%$ e a análise das regressões lineares calculando-se os coeficientes das equações lineares (angular e intercepto) e selecionados as correlações dos resultados de interesse que apresentaram correlação significativa $(p<0,05)$. Nestes casos, foi empregada a metodologia de Superfície de Resposta para determinar as respostas dos parâmetros de TPA de maneira a determinar os efeitos principais e as interações entre as variáveis independentes composição e intensidade do tratamento térmico. As médias obtidas das variáveis foram ajustadas pelo método dos quadrados mínimos ao modelo de primeira ordem ponderado, ao nível de $5 \%$ de significância. 


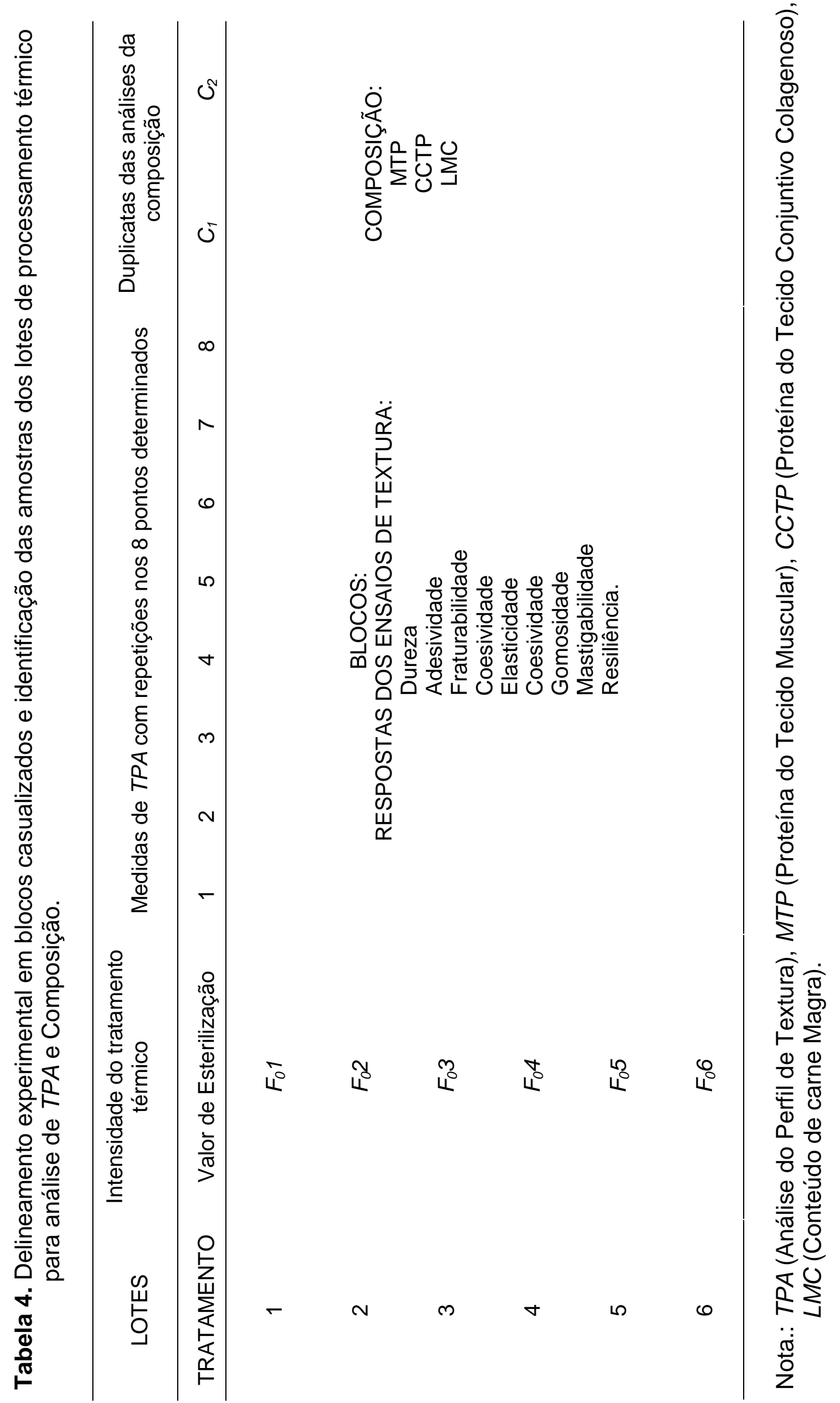




\section{RESULTADOS E DISCUSSÃO}

\subsection{Perfil de temperatura e valor de esterilização}

Os resultados de penetração de calor obtido para cada tratamento térmico representados graficamente nas Figuras 8 a 13, apresentaram perfis de temperatura, medida no centro de massa do produto (ponto de aquecimento mais lento), típicos para produtos aquecidos predominantemente por condução com as curvas da fase de aquecimento e de resfriamento com leve inclinação, resultando em tempos de processamento relativamente longos, cerca de 90 minutos para o produto ser aquecido de $37^{\circ} \mathrm{C}$ até cerca de $120^{\circ} \mathrm{C}$ e 60 minutos para ser resfriado até cerca de $40^{\circ} \mathrm{C}$. Observa-se uma queda na temperatura do corned beef mais acentuada na fase de resfriamento, para os casos dos tratamentos 5 e 6 , relativos à posição de medição da temperatura $\mathrm{T} 4$, devido ao posicionamento das latas mais próximas à entrada da água de resfriamento. Pode-se observar claramente o efeito do maior gradiente de temperatura (entre o produto e o meio) no início das fases de aquecimento e de resfriamento, com uma acentuada inclinação no perfil de temperatura do produto; contrariamente ao que ocorre no final das duas fases, quando a temperatura do produto se aproxima da temperatura do meio.

Algumas descontinuidades (picos repentinos para baixo e para cima nas curvas) podem ser observadas, provocados por descontinuidades do sinal elétrico proveniente dos termopares, os quais foram tratados por meio de suavização numérica dos perfis de temperatura não influenciando significativamente, portanto nos cálculos.

$\mathrm{Na}$ Tabela 5 pode-se observar que os valores $F_{h}$ variaram de 14,204 a 15,731 minutos, calculados de acordo com a Equação 4a, a partir do instante em que a temperatura da autoclave atinge $121^{\circ} \mathrm{C}$ nos respectivos tratamentos. Entretanto a contribuição da taxa letal do resfriamento, representado pelo valor $F_{c}$ teve uma larga amplitude de variação de 0,630 a 5,144 minutos, embora o tempo de resfriamento tenha sido mantido fixo em 60 minutos com a água à temperatura média de $35^{\circ} \mathrm{C}$. Esta variação foi mais 
acentuada nos tratamentos 5 e 6 devido à posição das latas submetidas a uma taxa de resfriamento mais acentuado.

$$
F_{o}=\int_{0}^{t} \frac{1}{10 \frac{121,1-T}{z}} d t
$$

Observa-se que todos os tratamentos atingiram o valor de $F_{0}$ mínimo de 6 minutos. Considerando o menor valor obtido de 14,835 minutos e como referência o microrganismo Clostridium sporogenes (PA 3679), com o valor $D_{121,10 \mathrm{C}}$ de 1,2 minutos e $z$ de $10^{\circ} \mathrm{C}$, foi aplicada uma destruição de cerca de 12 vezes o valor $D(12 D)$. Em termos de probabilidade, este tratamento apresentaria um risco de uma lata em um trilhão $\left(10^{12}\right)$ de latas apresentar um esporo viável do microorganismo. Isto satisfaz de forma excessiva os requisitos de segurança alimentar e estabilidade microbiológica do produto, tanto para a legislação brasileira quanto norte-americana. Por outro lado, este tratamento resulta entre outros efeitos térmicos, em alterações nos atributos de qualidade do produto notadamente a textura. Neste sentido, a intensidade do tratamento térmico foi mais intensa no tratamento 1 , seguido pelos tratamentos 2, 3, 4, 6 e 5 .

Uma considerável redução no tempo de processamento pode ser considerada tanto nas fases de aquecimento e resfriamento em relação ao esquema de processamento usualmente aplicado na indústria. Conforme o monitoramento do processo térmico apresentado para latas de $340 \mathrm{~g} \mathrm{o}$ programa de processamento utilizado é de no mínimo 75 minutos a $121^{\circ} \mathrm{C}$ e o resfriamento durante 60 minutos. Entretanto, na prática o tempo de aquecimento variou entre 75,03 e 76,65 minutos resultando em valores de esterilização $F_{0}$ de 14,8 a 20 minutos, o que caracteriza um super processamento para microrganismos, com possíveis efeitos para textura.

Tabela 5. Valores de esterilização calculados $\left(F_{h}\right),\left(F_{c}\right)$ e $\left(F_{0}\right)$ para os tratamentos térmicos.

\begin{tabular}{|c|c|c|c|c|}
\hline \multirow{2}{*}{$\begin{array}{c}\text { Tratamento } \\
\left(F_{0}\right)\end{array}$} & \multirow{2}{*}{$\begin{array}{l}\text { Posição da lata } \\
\text { (termopar) }\end{array}$} & \multicolumn{3}{|c|}{ Somatórios das taxas letais (min) } \\
\hline & & Aquecimento $\left(F_{h}\right)$ & Resfriamento $\left(F_{c}\right)$ & Total $\left(F_{0}\right)$ \\
\hline 1 & T2 & 14,947 & 5,069 & 20,016 \\
\hline 2 & T3 & 15,731 & 3,816 & 19,547 \\
\hline 3 & $\mathrm{~T} 1$ & 14,232 & 5,144 & 19,377 \\
\hline 4 & T5 & 14,854 & 2,832 & 17,685 \\
\hline 5 & T4 & 14,204 & 0,630 & 14,835 \\
\hline 6 & T4* & 15,056 & 0,630 & 15,686 \\
\hline
\end{tabular}




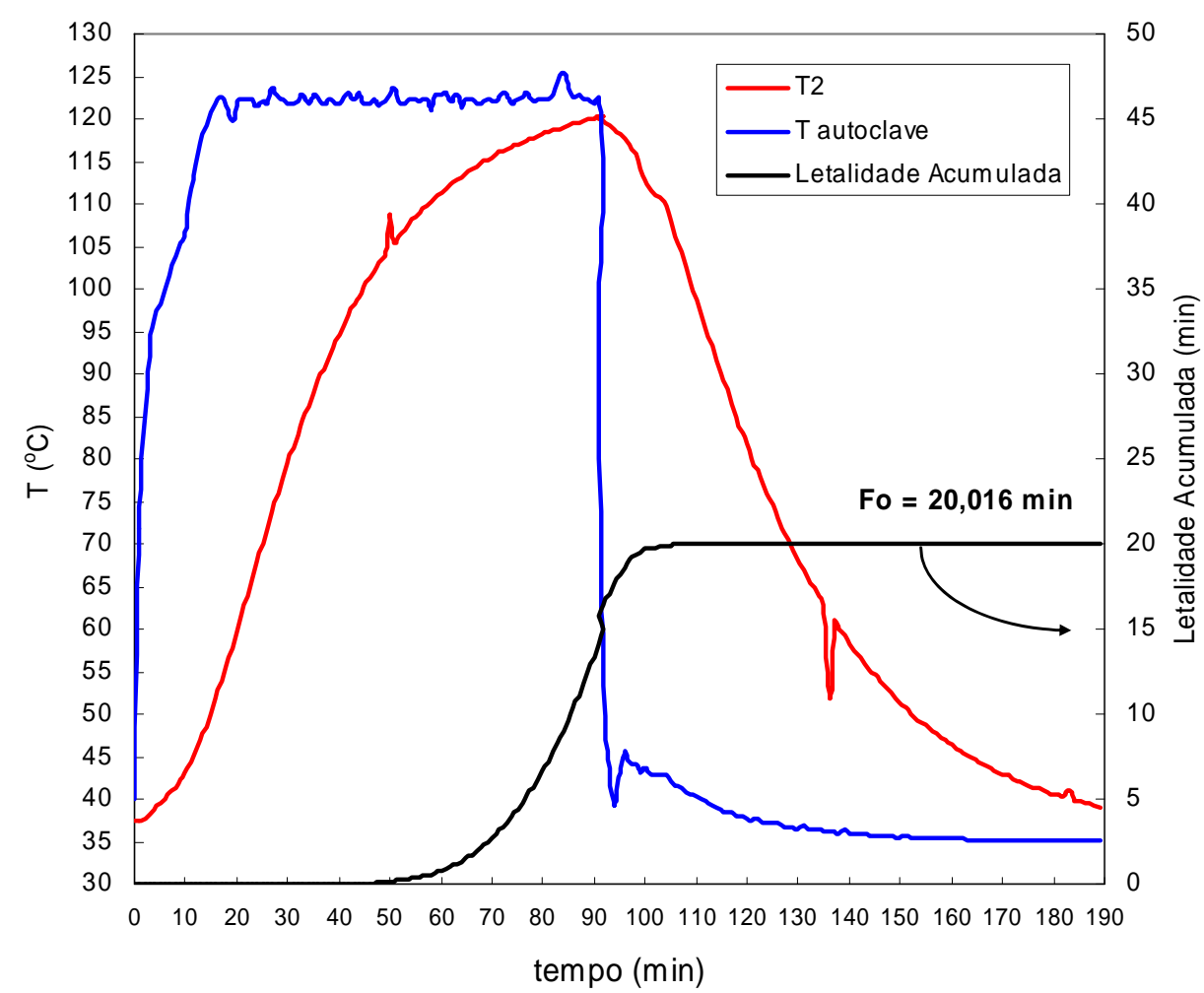

Figura 8. Tratamento 1 - Curva de penetração de calor no processamento térmico em autoclave.

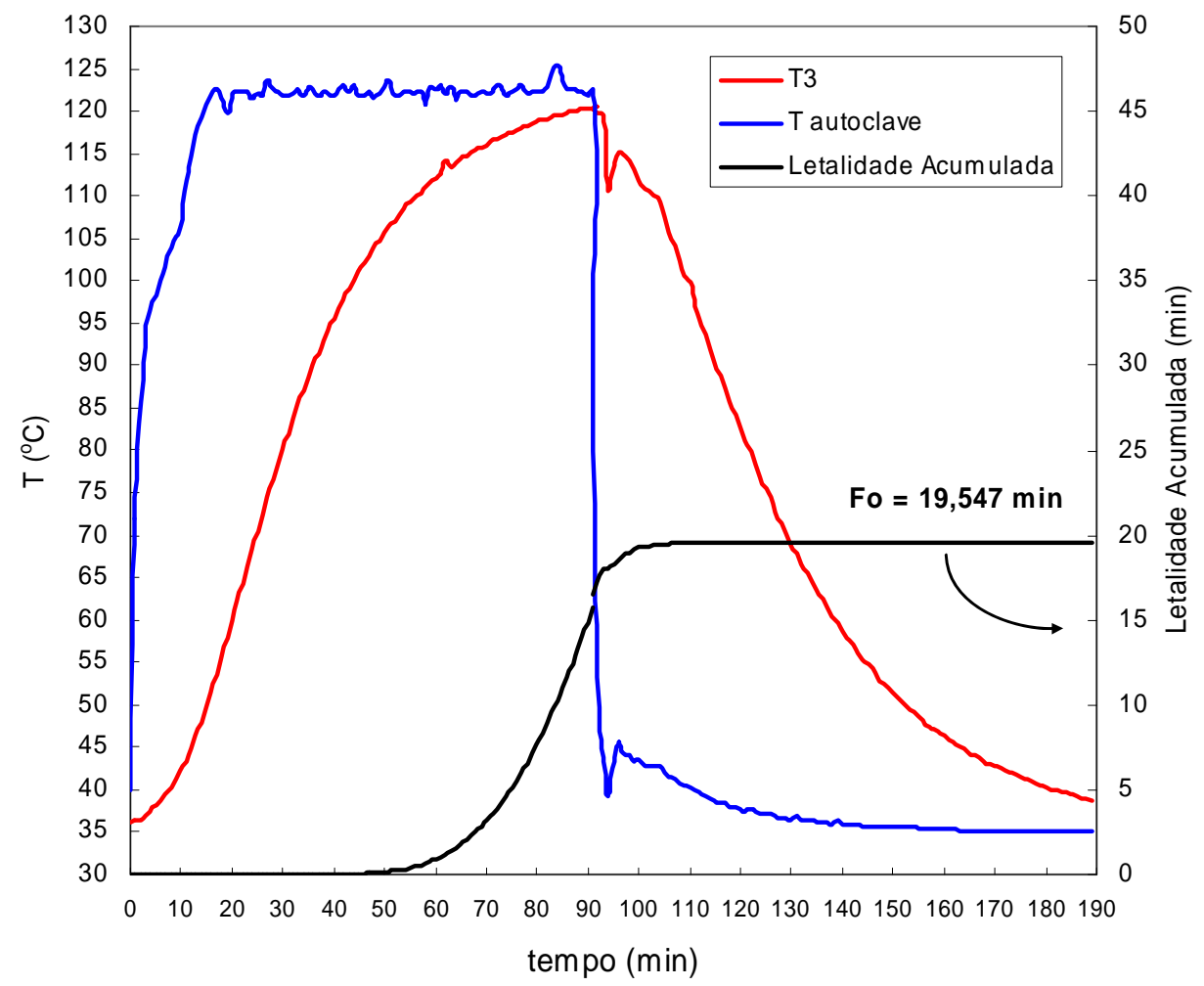

Figura 9. Tratamento 2 - Curva de penetração de calor no processamento térmico em autoclave. 


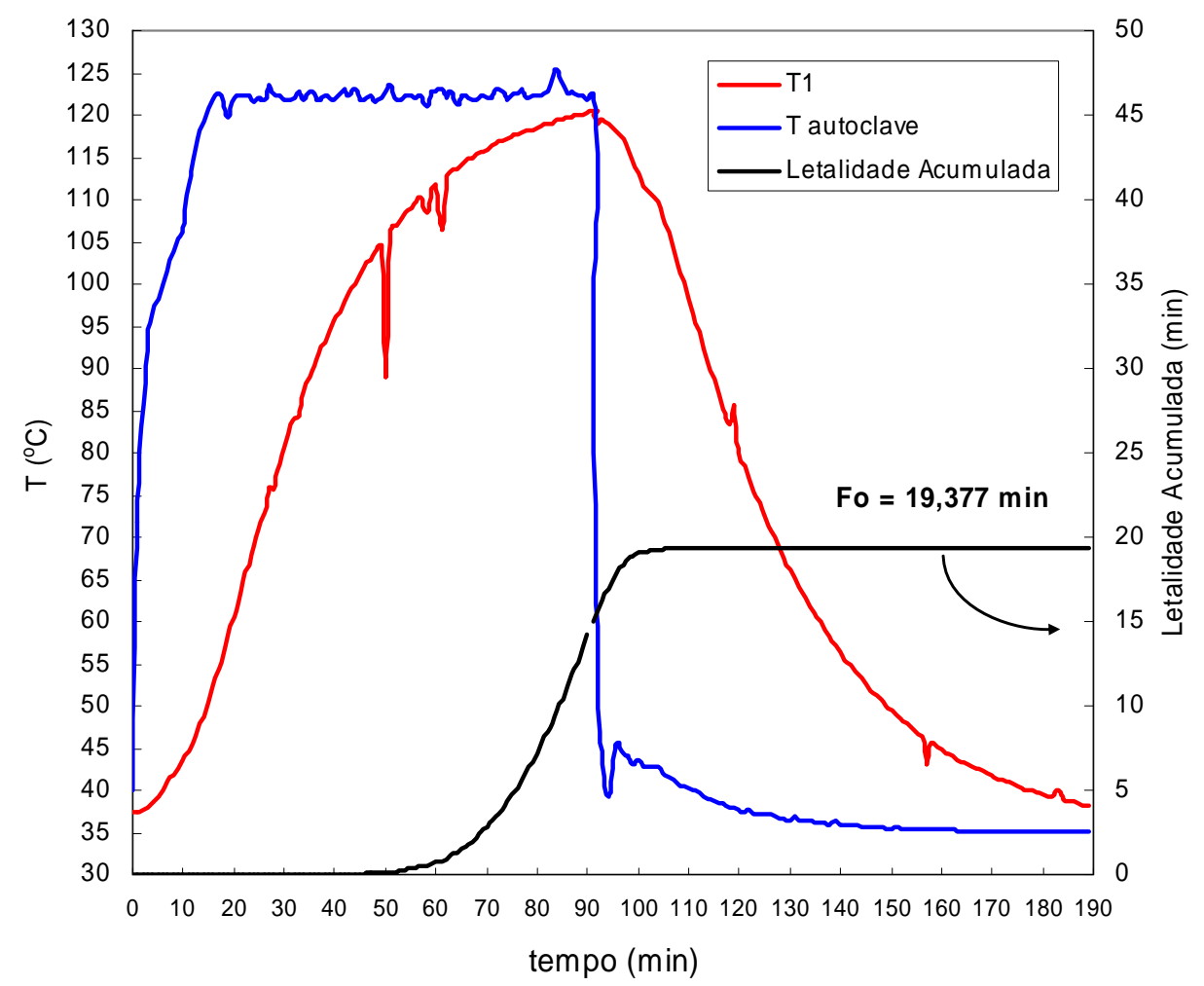

Figura 10. Tratamento 3 - Curva de penetração de calor no processamento térmico em autoclave.

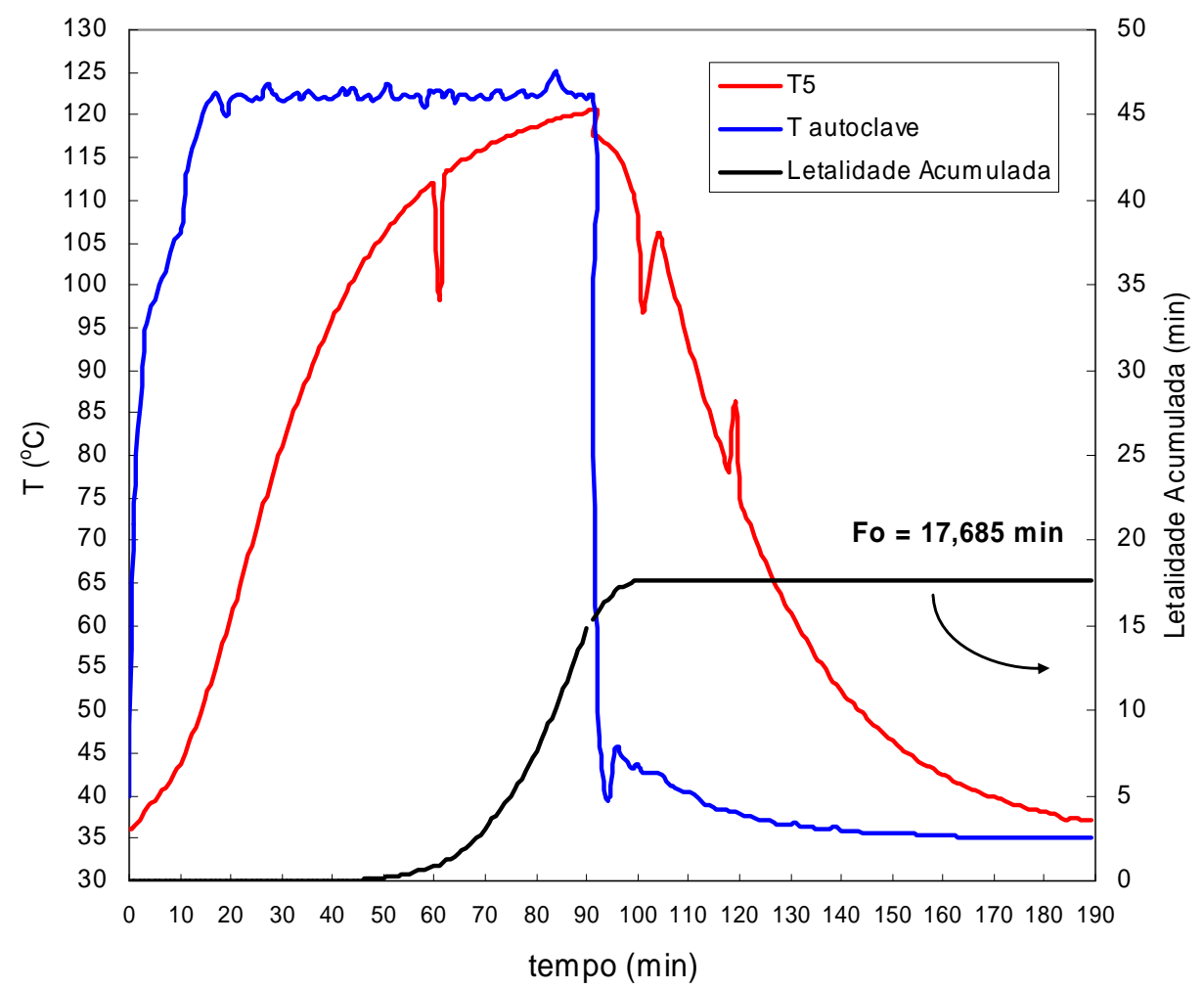

Figura 11. Tratamento 4 - Curva de penetração de calor no processamento térmico em autoclave. 


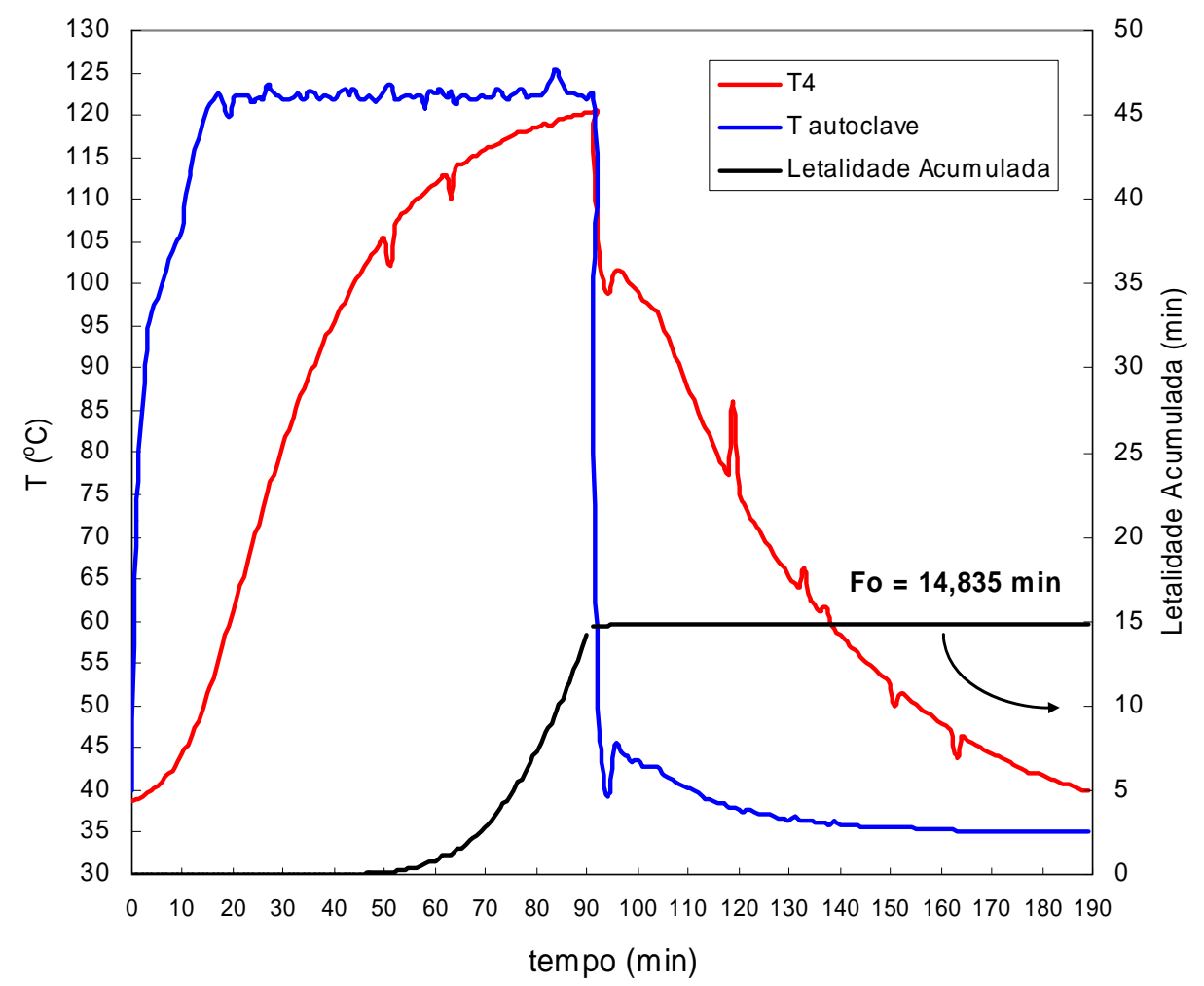

Figura 12. Tratamento 5 - Curva de penetração de calor no processamento térmico em autoclave.

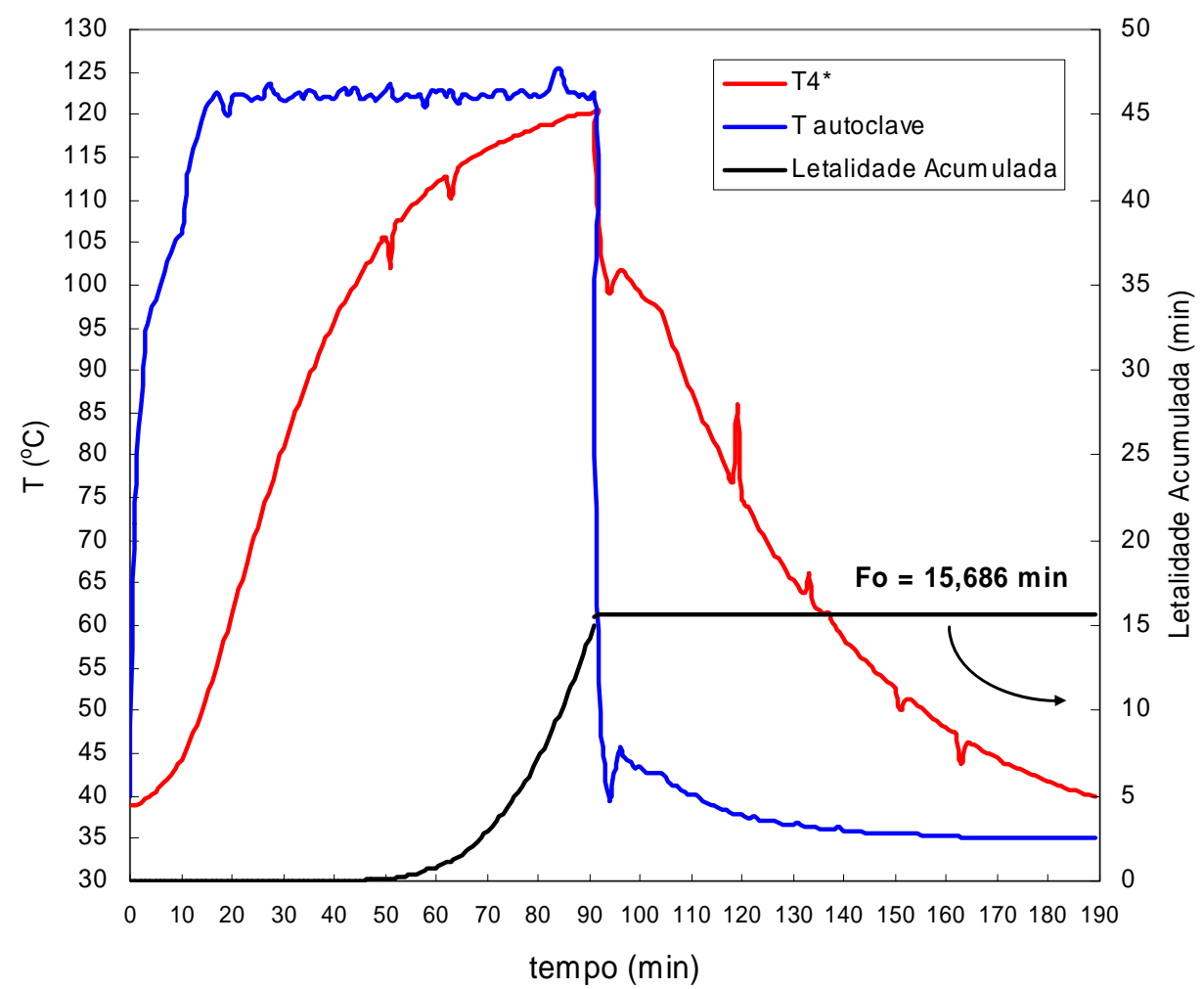

Figura 13. Tratamento 6 - Curva de penetração de calor no processamento térmico em autoclave. 


\subsection{Perfil de Textura - TPA}

A Tabela 6 apresenta os resultados da análise do perfil de textura instrumental, para cada um dos parâmetros de textura determinados nos oito pontos (Figuras 4, 5a e 5b) nas amostras dos blocos de corned beef resfriados dos tratamentos de 1 a 6 . Com base no teste $t$ de Student $(P<0,05)$, os valores de cada parâmetro de TPA obtidos nos tratamentos apresentaram distribuição normal, excetuando-se a fraturabilidade do tratamento $6(P>0,05)$. Os parâmetros relacionados entre si como dureza, gomosidade (dureza $\times$ coesividade) e mastigabilidade (dureza $\times$ coesividade $x$ elasticidade) apresentaram coeficientes de variação (CV), entre 25 e 37\% nos tratamentos 1, 2 e 3. Nos demais parâmetros, o CV apresentou valores abaixo de $25 \%$ (com exceção da fraturabilidade e da adesividade apenas no tratamento 6), com a elasticidade apresentando menores CV (2,5\%). Em relação ao erro padrão da média (EPM) apenas a fraturabilidade apresentou valores elevados próximos a $50 \%$.

A variação da fraturabilidade expressa pela tensão de ruptura no trabalho da primeira compressão foi notável em todos os parâmetros estatísticos avaliados (DP, CV, EPM, valor $p$ ) entre os tratamentos e também numa mesma amostra, provavelmente devido à presença de pedaços de tecido conjuntivo das aponeuroses, perimísio e endomísio, tanto os aderidos na parte externa como os do interior dos pedaços de tecido muscular. Embora o tecido conjuntivo (endomísio e perimísio) presente nos recortes de carne ocorra em proporção natural, existe uma variação significativa, devido ao tipo de refilamento (trimming) na produção dos cortes anatômicos que gera estes retalhos. Pode-se observar visualmente ao se fatiar o produto, a presença do tecido colagenoso parcialmente gelificado e com textura mais elástica que o tecido muscular, o que pode ter causado a interrupção da força durante 0 trajeto de penetração da sonda na primeira compressão, ocasionando as variações na fraturabilidade. Este fato pode ser explicado se considerarmos que o colágeno do perimísio e do endomísio possuem mais ligações cruzadas termo estáveis do que o colágeno dos tendões.

Amostras dos mesmos lotes utilizados na presente pesquisa foram avaliadas quanto à textura sensorial, com base simplesmente na aceitação 
ou rejeição, pela equipe do controle de qualidade da indústria onde o processamento foi conduzido. Estes resultados encontram-se no Anexo 3. A graduação Campden A, segundo a Campden \& Chorelywood Food Research Association - CCFRA (2001), especifica que o bloco de corned beef deverá ser razoavelmente firme e proporcionar a sensação de mastigar carne e apresentar uma razoável textura fibrosa, mas sem pedaços duros e difíceis de mastigar. Pode ser levemente pastosa, graxenta, ou borrachuda, entretanto sem quebras ou desintegração das fatias durante o corte e manuseio. Esse conceito apesar de subjetivo, foi possível de ser aplicado pela equipe de analistas sensoriais do Controle de Qualidade recebendo a graduação Campden $\mathrm{A}$, sendo também avaliadas pela equipe de análise sensorial da auditoria de qualidade do cliente, antes do embarque do produto, obtendo-se a mesma graduação. Ainda assim, considera-se fundamental estabelecer-se uma correlação entre as metodologias de análise sensorial e a instrumental de análise do perfil de textura, tendo em vista a grande complexidade envolvida na definição e conceituação do perfil de textura de um produto com elevado grau de heterogeneidade como o corned beef. A avaliação da textura envolvendo parâmetros objetivos será de grande valor para melhor classificação comercial da qualidade do produto.

As propriedades de textura de importância neste produto são principalmente aquelas que estão relacionados com a capacidade de adesão (binding) e coesão das partículas de carne como a dureza, adesividade e coesividade. A elasticidade é uma propriedade importante também na redução da quebra das fatias no processo de fatiamento.

Neste sentido, os parâmetros de TPA mais significativos podem ser utilizados tanto para avaliar a textura percebida sensorialmente pelo consumidor durante a degustação, como também no aspecto de conveniência do produto durante seu porcionamento e preparação. A análise do perfil de textura representa uma das técnicas instrumentais mais valorizadas para medir simultaneamente vários parâmetros de textura nos alimentos. A indústria de alimentos foi precursora deste teste que tenta imitar as condições em que os alimentos são submetidos à mastigação na boca. Considerando o conceito de textura do produto de acordo com a especificação Campden e dos analistas sensoriais, a dureza e a 
mastigabilidade estão relacionadas com a desejável sensação de mastigação de porções de tecido muscular (carne) com textura ligeiramente fibrosa (fibras musculares), devido à presença predominante de pedaços de carne (tecido muscular) em relação à carne cominutada no corned beef. A coesividade e a adesividade (trabalho para retirar a sonda) relacionam-se com a resistência da estrutura do produto durante o fatiamento e mastigação que depende do estado de compactação e adesão dos pedaços de carne pelo colágeno gelificado. Um aumento da intensidade do tratamento térmico provoca uma maciez excessiva devido à solubilização do colágeno intramuscular e a desintegração das fibras musculares. A presença excessiva de carne cominutada na formulação, tornando a textura do produto pastosa, implica em baixos valores de coesividade e gomosidade. $O$ aumento da fraturabilidade e a baixa elasticidade estão relacionados com as quebras das fatias durante o porcionamento. A resiliência consiste na capacidade de um produto retornar ao estado inicial (formato) antes de sofrer a deformação pela compressão. Este parâmetro é de difícil correlação com as características do corned beef devido sua característica de desintegração quando o mesmo é submetido a uma tensão de deformação.

\subsection{Composição do corned beef dos tratamentos}

Os resultados da composição média do bloco integral de corned beef homogeneizado estão apresentados na Tabela 7. A umidade apresentou grande variação nos tratamentos, de $55,44 \%$ para o tratamento 2 a $61,65 \%$ no tratamento 6 . Os lipídeos apresentaram uma amplitude de variação de 10,24 a 14,87\%. Entretanto a Proteína Total da Carne (TMP) apresentou pequena variação de 23,46 a 25,84\% que resultou em valores de "Conteúdo de Carne Magra" (LMC) mais que suficientes (102,79 a 107,95\%) para atingir o mínimo especificado pela legislação de $96 \%$. Entretanto o "Conteúdo Total de Carne" (TMC) apresentou vários valores abaixo do valor mínimo 120\%, ocasionado pela grande amplitude de variação nos teores de lipídeos. 


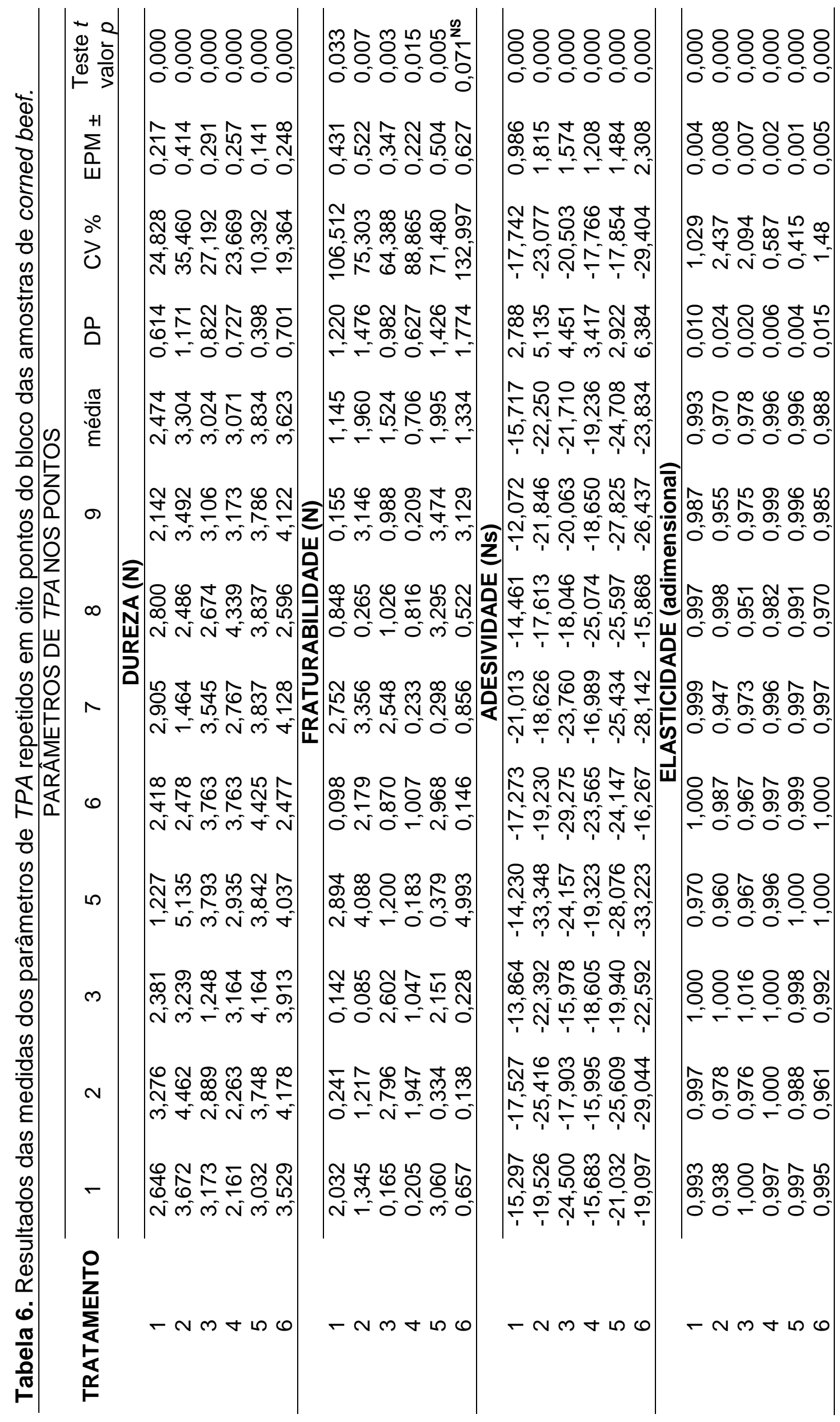




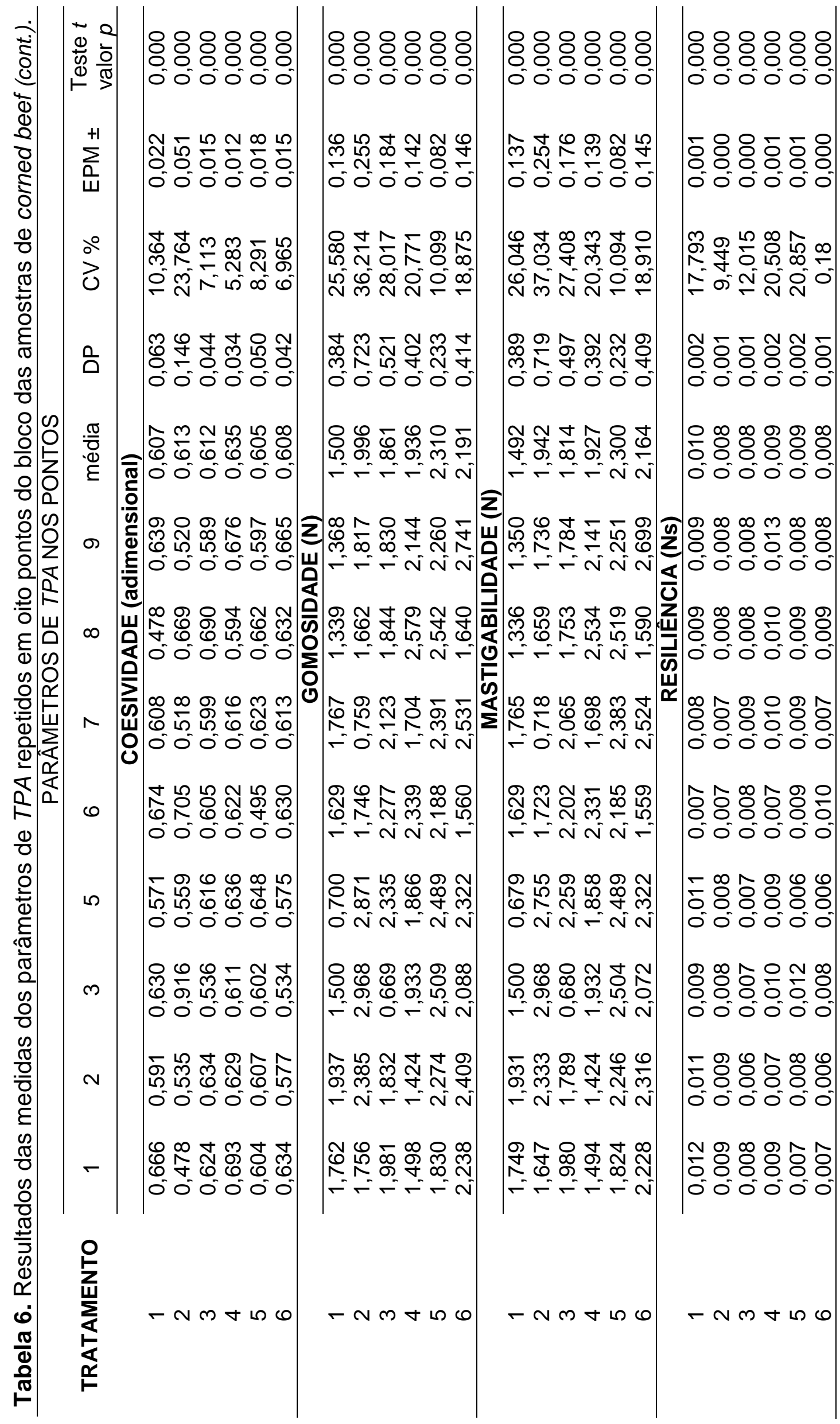


A variação na concentração de $\operatorname{CCTP}(0,54$ a $2,45 \%)$ encontrada nos lotes analisados está de acordo com a variação esperada em função da variação do percentual de tendões adicionados nos lotes de mistura, o que corresponde a 1,41 a 1,9\% na concentração de CCTP para um rendimento do tendão no cozimento de $56 \%$ e com o fator de conversão do colágeno para tecido conjuntivo de 4,625 (CLITRAVI, 2002). Para uma eventual aplicação da concentração de CCTP na otimização da textura do corned beef, quando da definição da formulação da mistura de ingredientes, deve-se determinar previamente o CCTP através do índice de hidroxiprolina nas matérias primas cozidas para o cálculo da MTP. Para calcular a proteína total da carne por diferença com mais precisão, pode-se adotar no somatório dos valores de composição centesimal, um fator correspondente ao percentual médio das cinzas e carboidratos determinados pelo método AOAC para este padrão e os percentuais reais de sal e açúcar adicionados.

A concentração do cloreto de sódio teve uma pequena variação de 2,33 a 2,51\% devido ao ajuste da quantidade de sal adicionado em cada lote. Estes valores estão dentro dos limites determinados pelo Codex Standard for corned beef (CODEX ALIMENTARIUS COMMISSION, 1991). O teor de cinzas teve uma variação considerável de 2,40 a 2,91\%.

\subsection{Análise de variância dos efeitos dos tratamentos térmicos $\left(F_{0}\right)$ e da posição de medida de TPA no bloco de corned beef}

Os efeitos dos fatores de tratamento térmico nos lotes analisados apresentaram diferenças significativas nos parâmetros dureza, adesividade, elasticidade e mastigabilidade, conforme pode ser observada na análise de variância (ANOVA) dos tratamentos, apresentada na Tabela 8. A gomosidade, parâmetro dependente da elasticidade, foi significativa no nível de confiança $\alpha$ de $10 \%$. Pode ser observado que em relação à posição nos pontos medidos no mesmo bloco (conforme Figura 5), não houve diferenças significativas para todos os parâmetros de TPA medidos. Estes resultados indicam que o aquecimento nesta região do bloco (Figura 4) foi uniforme, demonstrando que a porção elegida ( $25 \%$ da altura do topo superior) foi 
adequada para determinação dos parâmetros de textura, devido a menor distancia entre a superfície e o centro de massa do produto.

As Tabelas $9 \mathrm{a}$ e $9 \mathrm{~b}$ foram construídas com base na diferença mínima significativa (DMS) do resultado do teste de Tukey para os tratamentos que apresentaram diferença significativa pela ANOVA, seguindo-se aplicação do contraste entres as médias para ordenação e separação das médias que diferem entre si e agrupamento em grupos homogêneos. Nos parâmetros gomosidade e mastigabilidade dependentes e relacionados com a dureza, classificados na Tabela 9a, existiu uma notável diferença nestes valores entre os tratamentos 1 e 5, o que pode ser explicado pela grande diferença de intensidade do tratamento térmico aplicados nestes lotes, $F_{0}$ variando de 20,0 a 14,8 minutos respectivamente. No tratamento 4 ( $F_{0}$ de 17,7 minutos) a dureza foi de $3,031 \mathrm{~N}$ e no tratamento 2 ( $F_{0}$ de 19,5 minutos) a dureza foi de $2,767 \mathrm{~N}$, indicando que teríamos uma melhoria na qualidade do tratamento 4 pela redução do amolecimento e da pastosidade. Entretanto, pelo teste de Tukey estes tratamentos não diferem entre si para o parâmetro dureza, o grupo 1 com os tratamentos 1, 2, 3, 4 e 6 foi considerado significativamente homogêneo, como também o grupo 2 com os tratamentos 2, 3, 4, 5 e 6 , ambos no nível $\alpha$ de $5 \%$. Os parâmetros gomosidade e mastigabilidade apresentaram a mesma distribuição de homogeneidade em relação à dureza por serem derivados deste ultimo parâmetro.

Em relação à adesividade, o grupo 1 com os tratamentos 2, 3, 4, 5 e 6 foi considerado significativamente homogêneo, como também o grupo $2 \mathrm{com}$ os tratamentos 1 , 3 e 4 , ambos no nível $\alpha 5 \%$. O mesmo comportamento foi observado para a elasticidade. 


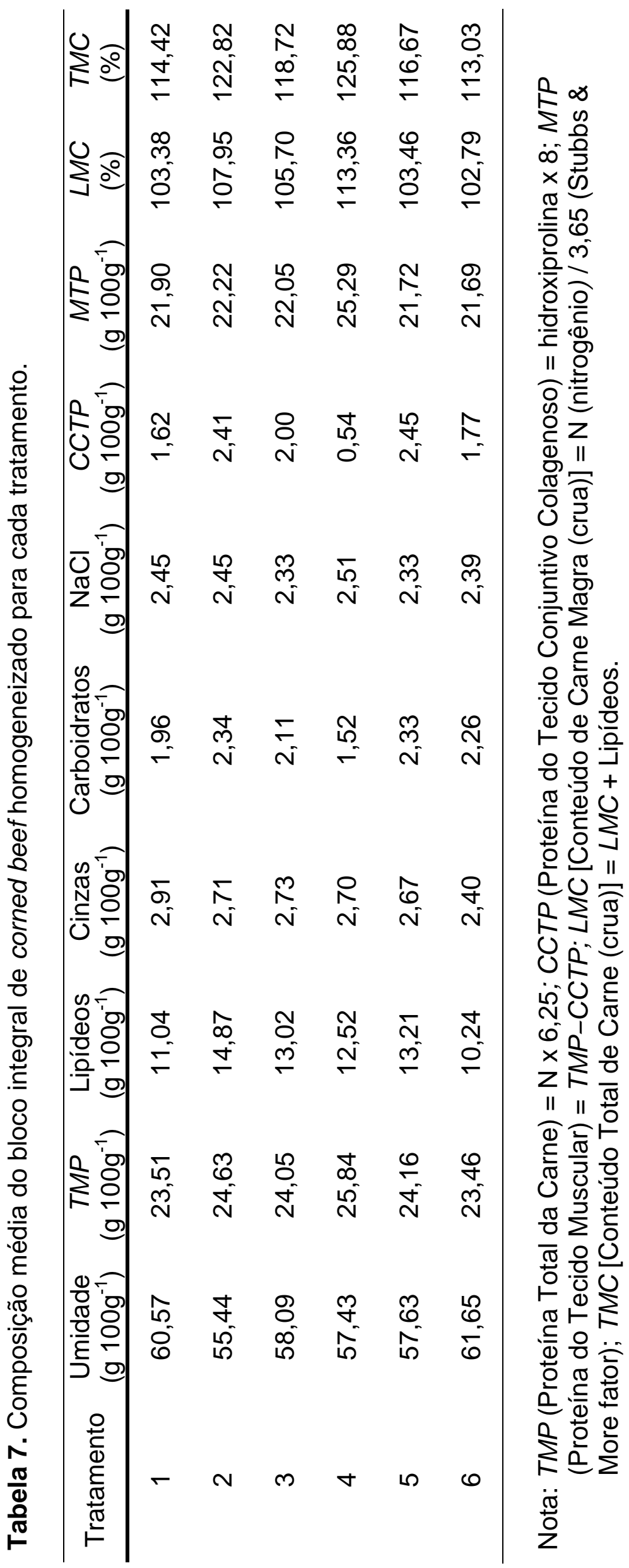


Tabela 8. Análise de Variância (ANOVA) dos efeitos dos seis fatores de tratamento $\left(F_{0}\right)$ em oito blocos (pontos de penetração da sonda no bloco de corned beef resfriado).

\begin{tabular}{|c|c|c|c|c|c|c|}
\hline$F V$ & $S Q$ & $G L$ & $Q M$ & F calc & valor $p$ & F crit \\
\hline \multicolumn{7}{|c|}{ DUREZA; ${ }^{*} \alpha=5 \%$} \\
\hline Tratamentos & 9,300 & 5 & 1,860 & $2,737^{*}$ & 0,034 & 2,485 \\
\hline Blocos & 1,450 & 7 & 0,207 & $0,305^{\text {ns }}$ & 0,947 & 2,285 \\
\hline Resíduo & 23,783 & 35 & 0,680 & & & \\
\hline Total & 34,534 & 47 & & & & \\
\hline \multicolumn{7}{|c|}{ FRATURABILIDADE; * $\alpha=5 \%$} \\
\hline Tratamentos & 9,781 & 5 & 1,956 & $1,086^{\text {ns }}$ & 0,385 & 2,485 \\
\hline Blocos & 8,385 & 7 & 1,198 & $0,665^{\text {ns }}$ & 0,700 & 2,285 \\
\hline Resíduo & 63,034 & 35 & 1,801 & & & \\
\hline Total & 81,199 & 47 & & & & \\
\hline \multicolumn{7}{|c|}{ ADESIVIDADE; ${ }^{*} \alpha=5 \%$} \\
\hline Tratamentos & 436,094 & 5 & 87,219 & $4,983^{*}$ & 0,002 & 2,485 \\
\hline Blocos & 191,850 & 7 & 27,407 & $1,566^{\mathrm{ns}}$ & 0,178 & 2,285 \\
\hline Resíduo & 612,647 & 35 & 17,504 & & & \\
\hline Total & 1240,590 & 47 & & & & \\
\hline \multicolumn{7}{|c|}{ ELASTICIDADE; ${ }^{*} \alpha=5 \%$} \\
\hline Tratamentos & 0,004 & 5 & 0,0009 & $4,018^{*}$ & 0,006 & 2,485 \\
\hline Blocos & 0,002 & 7 & 0,0003 & $1,211^{\text {ns }}$ & 0,323 & 2,285 \\
\hline Resíduo & 0,008 & 35 & 0,0002 & & & \\
\hline Total & 0,014 & 47 & & & & \\
\hline \multicolumn{7}{|c|}{ COESIVIDADE; ${ }^{*} \alpha=5 \%$} \\
\hline Tratamentos & 0,005 & 5 & 0,001 & $0,155^{\text {ns }}$ & 0,977 & 2,485 \\
\hline Blocos & 0,009 & 7 & 0,001 & $0,210^{\text {ns }}$ & 0,981 & 2,285 \\
\hline Resíduo & 0,218 & 35 & 0,006 & & & \\
\hline Total & 0,232 & 47 & & & & \\
\hline \multicolumn{7}{|c|}{ GOMOSIDADE; ${ }^{*} \alpha=5 \%$} \\
\hline Tratamentos & 3,191 & 5 & 0,638 & $2,483^{\text {ns }}$ & 0,050 & 2,485 \\
\hline Blocos & 0,305 & 7 & 0,044 & $0,170^{\text {ns }}$ & 0,990 & 2,285 \\
\hline Resíduo & 8,996 & 35 & 0,257 & & & \\
\hline Total & 12,492 & 47 & & & & \\
\hline \multicolumn{7}{|c|}{ GOMOSIDADE; ** $\alpha=10 \%$} \\
\hline Tratamentos & 3,191 & 5 & 0,638 & $2,483^{* *}$ & 0,050 & 2,019 \\
\hline Blocos & 0,305 & 7 & 0,044 & $0,170^{\text {ns }}$ & 0,990 & 1,896 \\
\hline Resíduo & 8,996 & 35 & 0,257 & & & \\
\hline Total & 12,492 & 47 & & & & \\
\hline \multicolumn{7}{|c|}{ MASTIGABILIDADE; ${ }^{\alpha} \alpha=5 \%$} \\
\hline Tratamentos & 3,169 & 5 & 0,634 & $2,530^{*}$ & 0,047 & 2,485 \\
\hline Blocos & 0,266 & 7 & 0,038 & $0,152^{\text {ns }}$ & 0,993 & 2,285 \\
\hline Resíduo & 8,768 & 35 & 0,251 & & & \\
\hline Total & 12,204 & 47 & & & & \\
\hline \multicolumn{7}{|c|}{ RESILIÊNCIA; ${ }^{*} \alpha=5 \%$} \\
\hline Tratamentos & 0,00003 & 5 & 0,000006 & $2,437^{\text {ns }}$ & 0,054 & 2,485 \\
\hline Blocos & 0,00001 & 7 & 0,000002 & $0,657^{\text {ns }}$ & 0,706 & 2,285 \\
\hline Resíduo & 0,00008 & 35 & 0,000002 & & & \\
\hline Total & 0,00012 & 47 & & & & \\
\hline
\end{tabular}

$\mathrm{FV}=$ fonte de variação; $\mathrm{SQ}=$ soma dos quadrados; $\mathrm{GL}=$ graus de liberdade; $\mathrm{QM}=$ quadrado médio (QM=SQ/GL); Fcalc $=\mathrm{QM} / \mathrm{QM}$ resíduo; ${ }^{*} \alpha=5 \%$; ** $\alpha=10 \%$, NS= não significativo. 


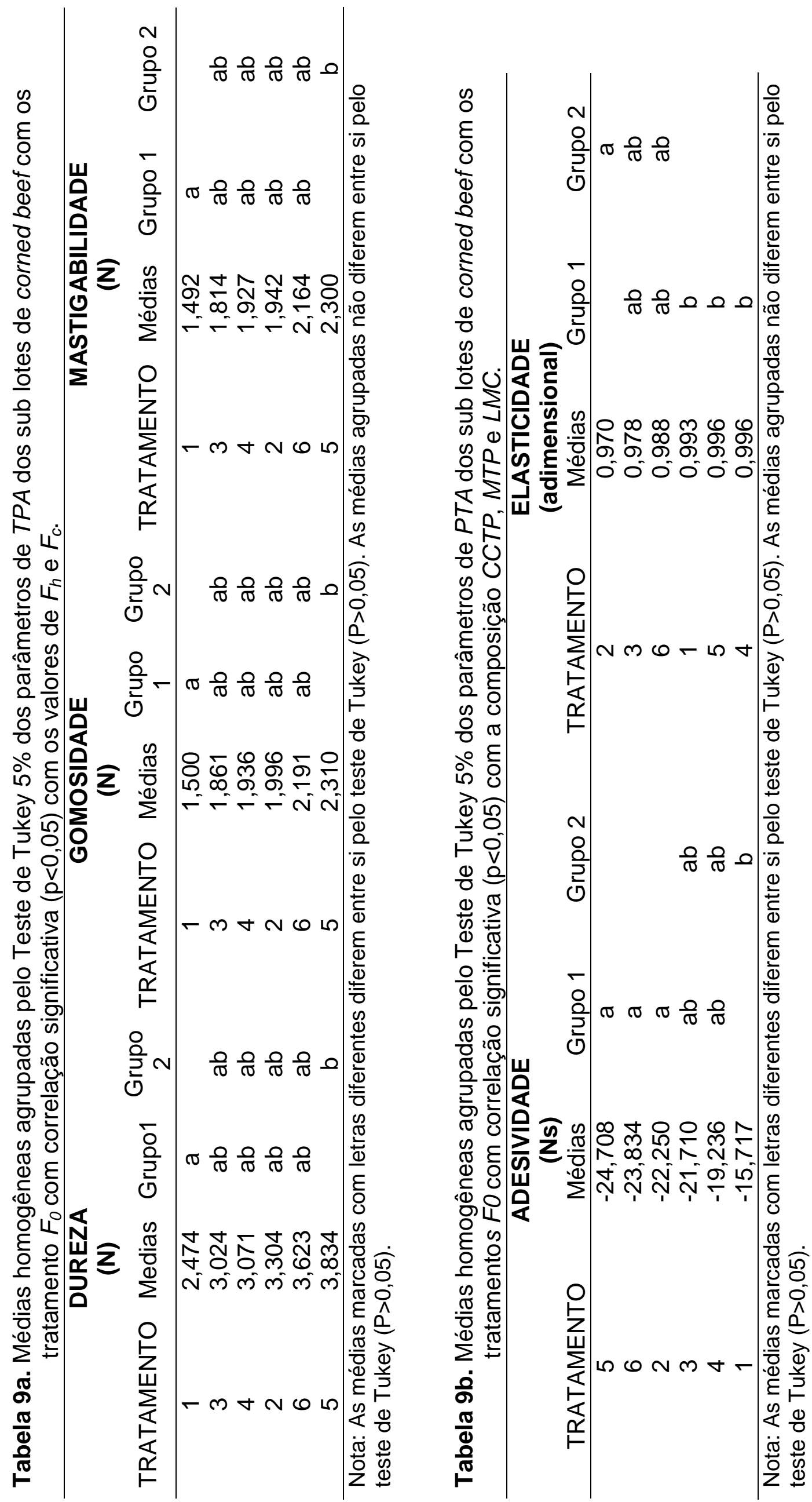




\subsection{Análise de correlação entre o tratamento térmico, a composição e os parâmetros de perfil de textura}

Os coeficientes de correlação de Pearson são apresentados na Tabela 10. Foi observada uma significativa $(P<0,05)$ correlação fortemente negativa do $F_{0}$ com as médias dos parâmetros dureza $(r=-0,85)$, gomosidade $(r=-$ $0,87)$ e mastigabilidade $(r=-0,90)$. Houve também uma significativa $(P<0,05)$ correlação semelhante do somatório das taxas de letalidade no resfriamento $\left(F_{c}\right)$ do processo térmico com a dureza $(r=-0,87)$, gomosidade $(r=-0,87)$ e mastigabilidade $(r=-0,90)$. Este fato deve-se ao valor $F_{c}$ do resfriamento que apresentou uma correlação significativa $(P<0,05)$ fortemente positiva $(r=0,96)$ com o valor total do somatório das taxas letais que resultaram nos valores $F_{0}$ de 14,8 a 20,0 minutos.

Embora o efeito dos tratamentos nos parâmetros fraturabilidade e coesividade não apresentou diferenças significativas $(P<0,05)$ entre os lotes testados pela ANOVA, o CCTP apresentou uma significativa $(P<0,05)$ correlação fortemente positiva com a média da fraturabilidade $(r=0,97)$ e uma correlação fortemente negativa $(P<0,05)$ com a média da coesividade $(r=-$ 0,83). A MTP e o LMC apresentaram correlações significativas $(P<0,05)$ fortemente positivas com a coesividade ( $r=0,99$ e 0,96 respectivamente).

A concentração de CCTP apresentou uma correlação moderada negativa com a adesividade $(r=-0,56)$ e com a elasticidade $(r=-0,51)$. Esta concentração variou em função do percentual de tendões adicionados nos lotes de mistura o que corresponde a 1,41 a 1,9\% na concentração de CCTP. Considerando as propriedades adesivas do colágeno dos tendões e 0 comportamento notadamente adesivo do produto, descrito no capítulo Materiais e Métodos, era esperado uma correlação de CCTP significativa $(\mathrm{P}<0,05)$ mais elevada com a adesividade. Entretanto esta moderada correlação pode ter sido influenciada pela intensidade do tratamento térmico $\left(F_{0}\right)$ o qual apresentou uma correlação fortemente positiva com a adesividade $(r=0,70)$ e moderadamente negativa com a elasticidade $(r=-0,51)$. Entretanto, uma maior concentração de CCTP no corned beef não proporcionaria por si só uma maior "força de gel" e conseqüentemente uma maior dureza, coesividade e influência na elasticidade e adesividade juntamente com os seus demais parâmetros decorrentes dos três primeiros, a gomosidade, 
mastigabilidade. Este resultado depende principalmente da intensidade do tratamento no processamento térmico, considerando o tratamento prévio dos tendões, aplicado na preparação do corned beef (moagem e cozimento). Um outro fator determinante foram as quantidades de tendões bovinos cozidos que não foram ajustadas nos lotes de mistura ocasionando uma variação de 3,72 a $5 \%$ na formulação.

De forma contrária, o aumento da concentração de CCTP corresponde à redução na concentração de MTP, a qual apresentou uma significativa correlação fortemente positiva com a coesividade $(r=0,99)$, demonstrando assim que a estrutura formada pelas proteínas miofibrilares é responsável pela coesividade do corned beef.

Como o corned beeef é preparado com uma composição de carnes previamente cozidas a temperatura de $98^{\circ} \mathrm{C}$ durante 10 minutos, estas modificações já ocorreram nas mesmas. A reestruturação deste tipo de produto inicia-se com a aplicação da pressão de compactação no enlatamento e a ligação (binding) dos pedaços pela adesão da gelatina proveniente dos tendões parcialmente gelificados. Assim sendo, o processo completo de gelificação dos tendões ocorrerá durante a etapa adicional de cozimento, que ocorre no processamento térmico, através do caldo liberado dos pedaços de músculo e eventual água adicionada na formulação, proporcionando assim a distribuição da gelatina formada entre os pedaços de músculo para efeito de adesão e no exterior do bloco para forma uma fina camada de revestimento no produto resfriado. Se a lata do produto for aberta logo após o envase, à temperatura de 55 ou $60^{\circ} \mathrm{C}$, ou após o tratamento térmico e resfriamento, quando a temperatura do produto está em torno de $35^{\circ} \mathrm{C}$, os pedaços de carne e de tecidos conjuntivos podem ser facilmente desagregados com o mínimo esforço manual, não existindo, portanto adesão suficiente para manter uma estrutura que permita o porcionamento e fatiamento do produto.

Para o bloco de corned beef poder ser fatiado é necessário o seu resfriamento a $4^{\circ} \mathrm{C}$, sendo esta uma característica bem definida na sua identidade e especificação. Isto se deve ao "ponto de solidificação" do gel formado (set point) que pode variar de 24 a $29^{\circ} \mathrm{C}$ dependendo da "força de gel", a qual depende do tratamento mecânico e térmico utilizado na obtenção 
da gelatina. Para produtos enlatados é necessária uma gelatina que forneça uma alta "força de gel", entretanto esta propriedade dependerá do tratamento térmico aplicado no produto final (POPPE, 1992).

A resiliência não apresentou correlação com os fatores de tratamento ( $F_{0}$ e composição) nem diferenças significativas em relação aos tratamentos aplicados.

\subsection{Efeito Simultâneo do Tratamento Térmico e da Composição no Perfil de Textura}

Os efeitos do tratamento térmico e da composição no Perfil de Textura (TPA) são apresentados de forma consolidada na Tabela 11. Para a composição do corned beef Campden A em latas tronco trapezoidais contendo $340 \mathrm{~g}$ de produto, com os valores de MTP variando de 21,90 a $25,29 \%$, CCTP de 0,54 a 2,45\% e o LMC de 102,79 a $107,95 \%$ e submetidas a diferentes valores de $F_{0}$ de 14,8 de 20,0 minutos, os valores dos parâmetros de TPA foram: dureza de 2,474 a 3,834 N, fraturabilidade de 0,706 a 1,995 N, adesividade de $-24,708$ a $-15,717 \mathrm{Ns}$, elasticidade 0,970 a 0, 996, coesividade 0,605 a 0,635, gomosidade de 1,500 a 2,310 N, mastigabilidade de 1,492 a 2,300 $\mathrm{N}$ e resiliência de 0,008 a $0,010 \mathrm{Ns}$.

Uma vez que a avaliação do PTA foi realizada no produto final esterilizado, os efeitos da composição estão associados ao calor. Para analisar estas interações foi utilizado o método da Superfície de Resposta com as curvas ajustadas pelo método dos quadrados mínimos. Como pode ser observado nos gráficos das Figuras 14 e 15, para a adesividade, a região da superfície com os valores mais altos (em força negativa Ns), entre -24 e 26, ocorreu com valores de $F_{0}$ entre 15 e 18 minutos e CCTP de 1,8\% a $2,4 \%$. No caso da elasticidade os valores mais elevados entre 0,999 e 1,000 foram obtidos com $F_{0}$ entre 14 e 15 minutos. 


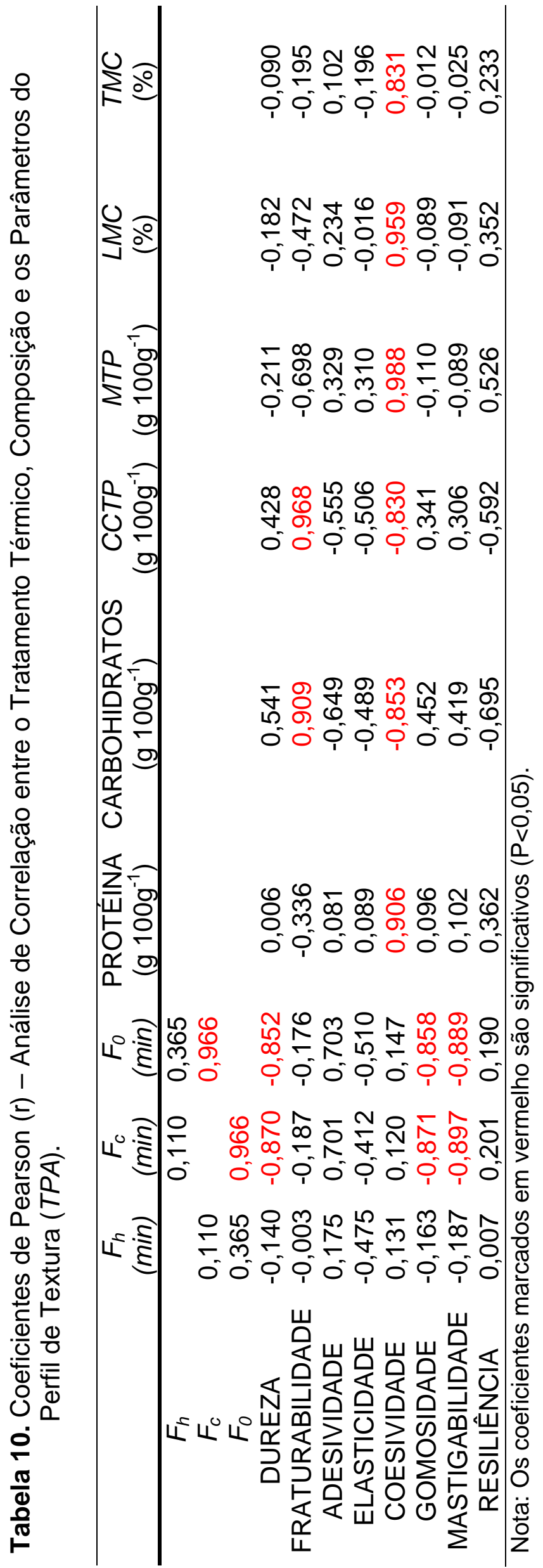




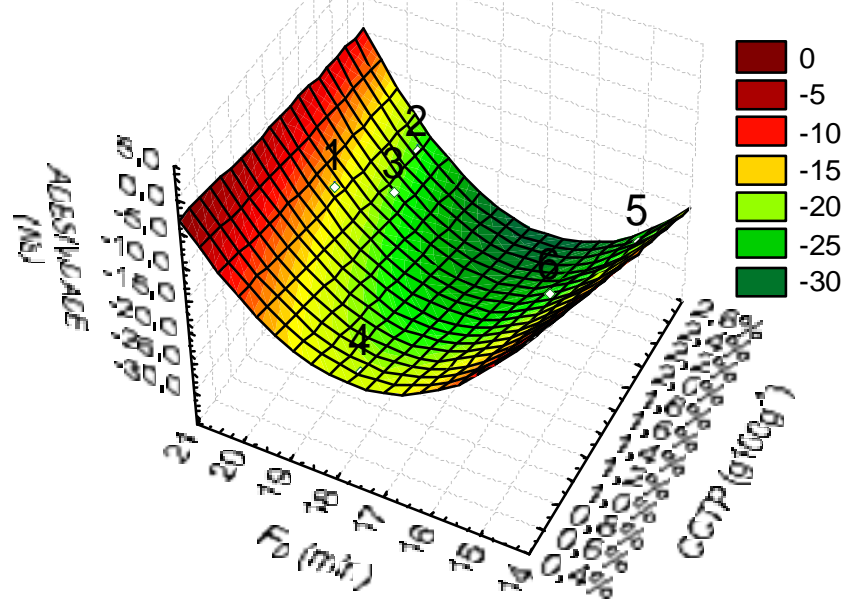

Figura 14. Superfície de resposta da adesividade em função do CCTP e $F_{0}$.

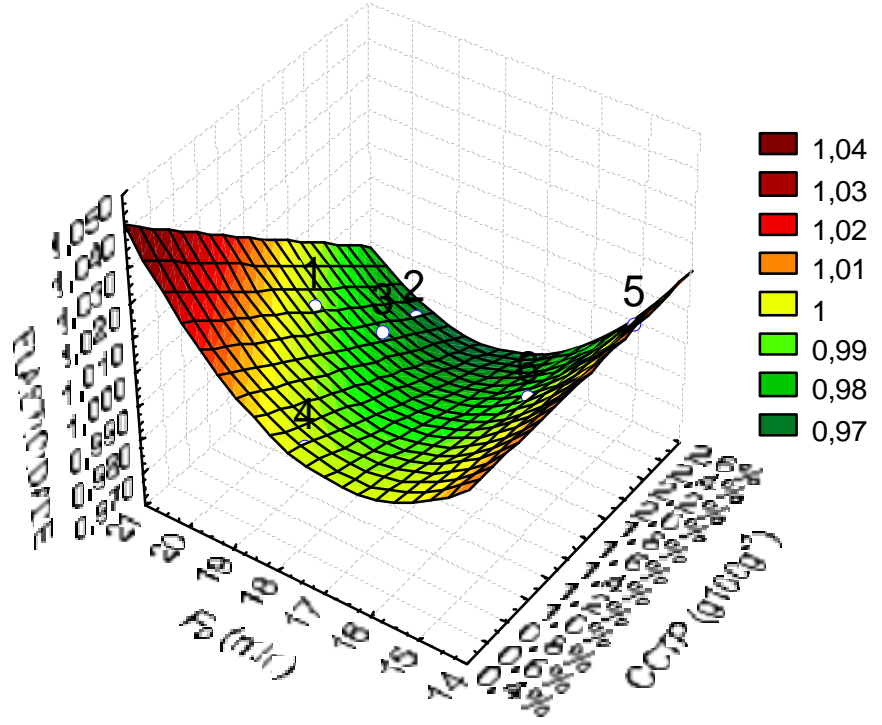

Figura 15. Superfície de resposta da elasticidade em função do CCTP e $F_{0}$. 
Os parâmetros que se comportaram dependentes do aquecimento como dureza, gomosidade e mastigabilidade podem ser incrementados reduzindose o valor de esterilização tanto na fase de aquecimento como na fase de resfriamento do processo térmico. Podemos verificar pelo gráfico de superfície de resposta da Figura 16 que para valores de $F_{0}$ de 14 a 17 minutos e MTP de 21,5 a $23,5 \%$, obteve-se uma dureza superior a $3 \mathrm{~N}$. Assim como os parâmetros dependentes como gomosidade e mastigabilidade apresentados nas Figuras 16 e 17 são mais elevados nesta mesma amplitude.

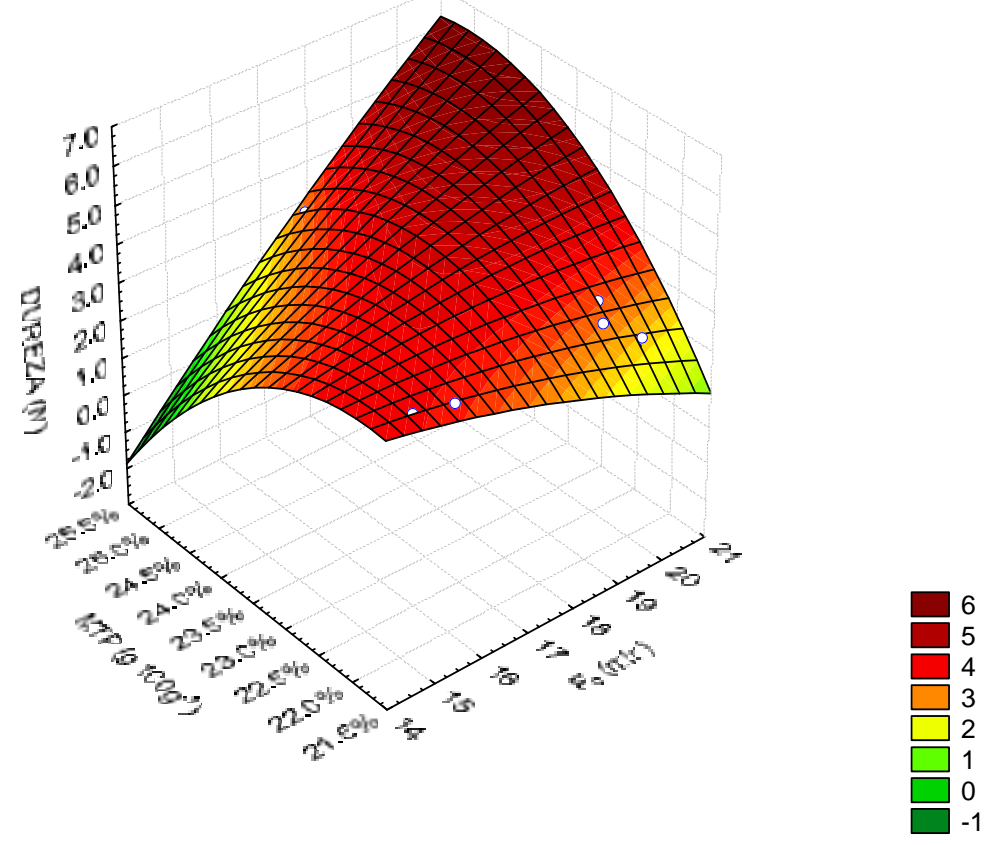

Figura 16. Superfície de resposta da dureza em função da MTP e $F_{0}$.

O aumento da concentração de CCTP corresponde à redução na concentração de MTP (correlação fortemente positiva com a coesividade ( $r=$ 0,99), demonstrando assim que a estrutura formada pelas proteínas miofibrilares é responsável pela coesividade do corned beef. Mesma conclusão foi observada no trabalho de Palka e Daun (1998) trabalhando com músculo semi-tendinoso bovino. Observa-se na Figura 19, o incremento da coesividade com o aumento da concentração de MTP entre os valores de $F_{0}$ de 14 a 17 minutos. 


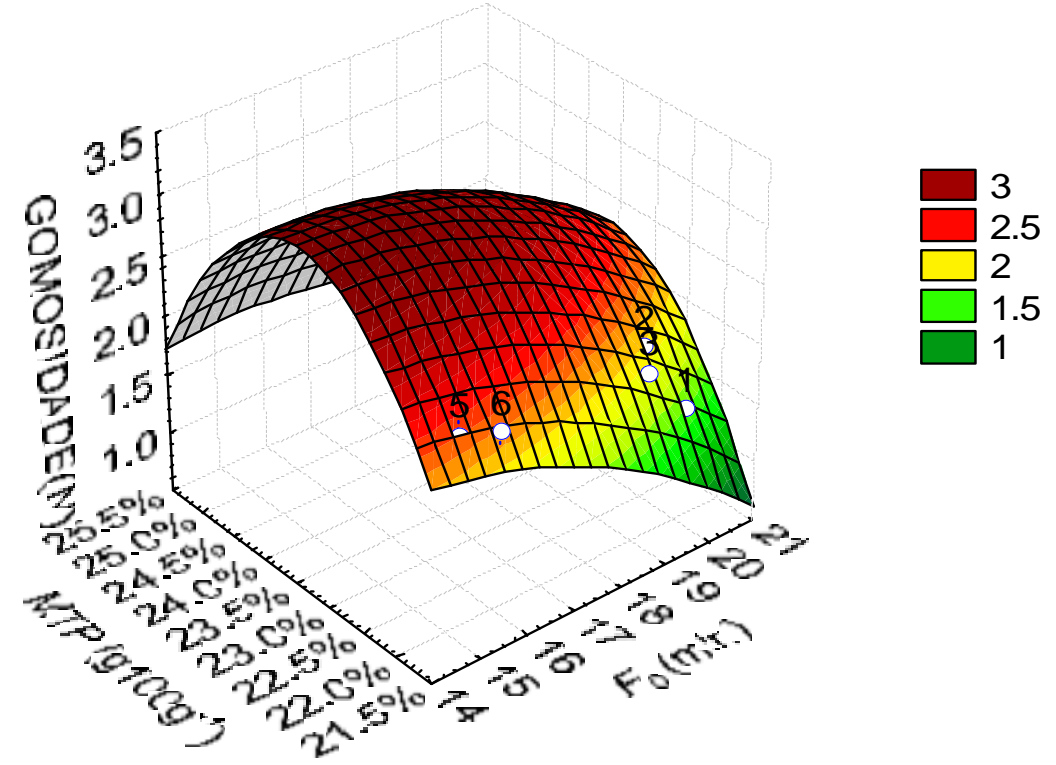

Figura 17 - Superfície de resposta da gomosidade em função do MTP e $F_{0}$.

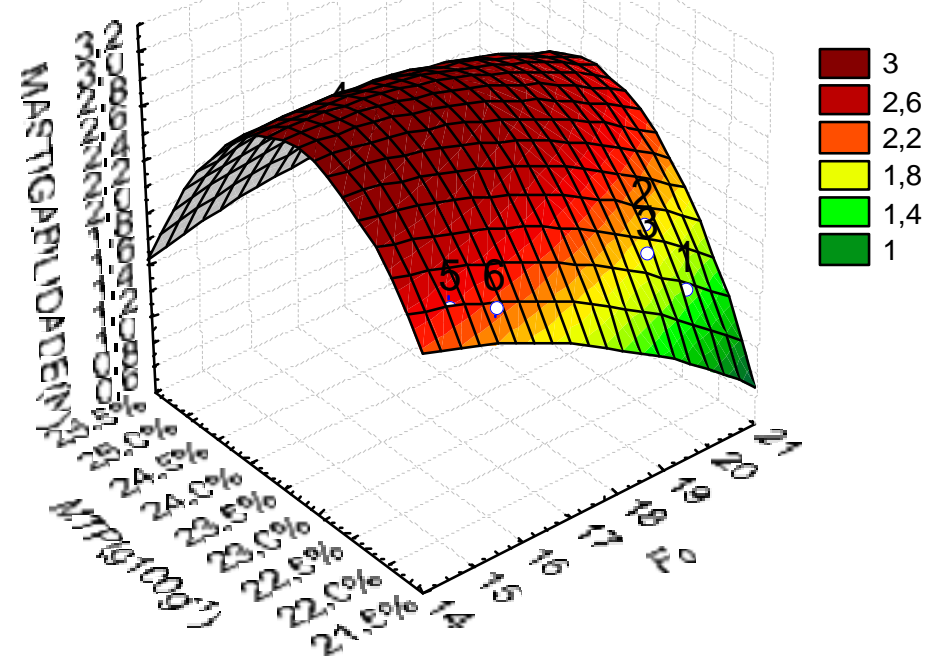

Figura 18. Superfície de resposta da mastigabilidade em função da $M T P$ e $F_{0}$. 


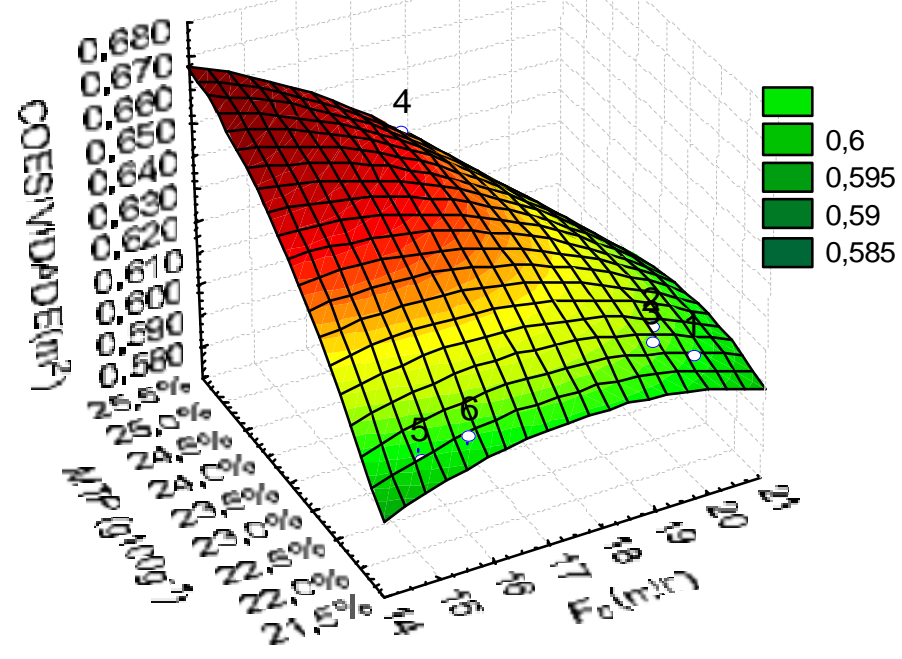

Figura 19. Superfície de resposta da coesividade em função da $M T P$ e $F_{0}$.

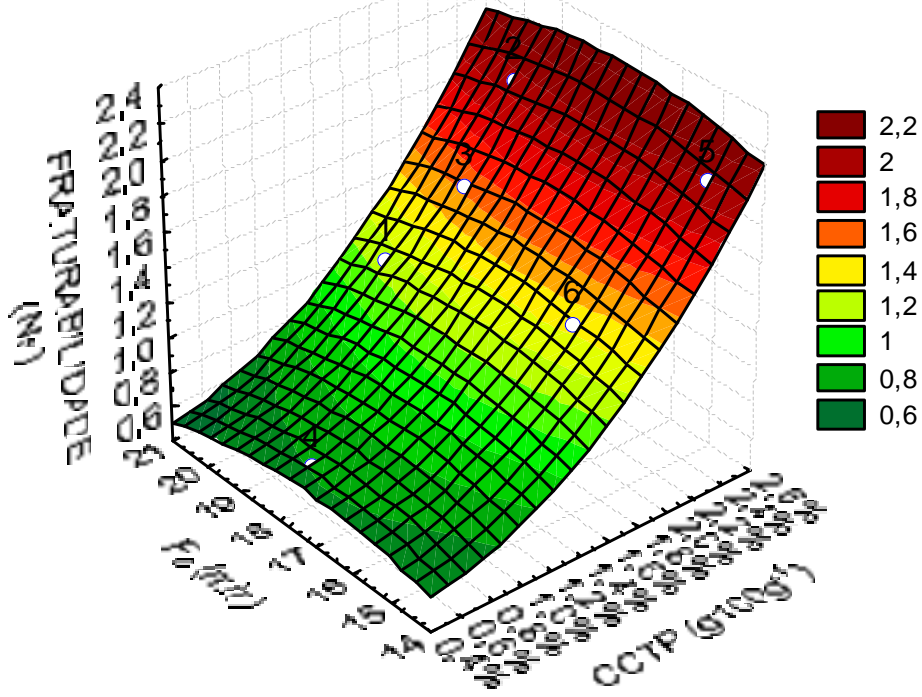

Figura 20. Superfície de resposta da fraturabilidade em função da CCTP e $F_{0}$. 
Pode-se observar claramente na Figura 200 incremento da fraturabilidade com o aumento da CCTP para toda amplitude dos valores de $F_{0}$.

As alterações das proteínas da carne bovina como a desnaturação, insolubilização e gelificação completam-se à temperatura de $90^{\circ} \mathrm{C}$ (PALKA, DAUN, 1998; LANTTO, 2007). Podem ocorrer dois efeitos nos parâmetros dureza, gomosidade e mastigabilidade dependentes da intensidade do tratamento térmico $\left(F_{0}\right)$ aplicado. Primeiro o aumento da maciez dos pedaços de carne através da alteração decorrente do cozimento no processamento térmico, que consiste principalmente na solubilização do colágeno muscular do tecido conjuntivo do endomísio e perimísio, os quais possuem mais ligações cruzadas termo estáveis do que o colágeno dos tendões. $O$ encolhimento e a solubilização parcial do colágeno do endomísio bovino iniciam-se a cerca de $62^{\circ} \mathrm{C}$ e completa-se aproximadamente a $70^{\circ} \mathrm{C}$ enquanto que no tecido conjuntivo do perimísio bovino é necessária uma temperatura inicial de $70^{\circ} \mathrm{C}$ para o encolhimento (PALKA, 1999). Além da faixa de temperatura para encolher e solubilizar o colágeno do tecido muscular ser mais alta que a necessária para o mesmo efeito nos tendões, o endomísio e perimísio estão localizados principalmente no interior dos pedaços de tecido muscular que corresponde aos pontos de aquecimento mais lentos dos pedaços de tecido muscular no corned beef. O segundo efeito é decorrente do aquecimento mais intenso das partículas de tendões (diâmetro aproximado $3,18 \mathrm{~mm}$ ) que os pedaços de tecido muscular (diâmetro aproximado $19,05 \mathrm{~mm}$ ) e também da menor quantidade (5\%) que os tecidos musculares $(78,22 \%)$ na formulação do produto, além de sua localização entre os pedaços de carnes permitirem um maior aquecimento. Também no colágeno dos tendões predominam mais ligações cruzadas termo lábeis do que no colágeno do endomísio e perimísio. Estas diferenças podem ocasionar a redução da "força de gel" da gelatina formada pela hidrólise deste tipo de colágeno. A relação da "força de gel" com a avaliação sensorial da consistência (dureza e coesividade) no corned beef foi confirmada por Shehata et al. (1994) que avaliou várias soluções de agentes gelificantes através da penetrometria com cones de alumínio e relacionou a distancia de penetração do cone no gel com a "força de gel". Os valores mais baixos da 
distancia de penetração a $20^{\circ} \mathrm{C}$ foram obtidos com as soluções de gelatina bovina seca granulada e tendões bovinos cozidos e moídos em disco com furos de $3 \mathrm{~mm}$ que os autores usaram na formulação do corned beef, cuja avaliação sensorial de consistência (dureza e coesividade) resultou em um dos melhores tratamentos. 


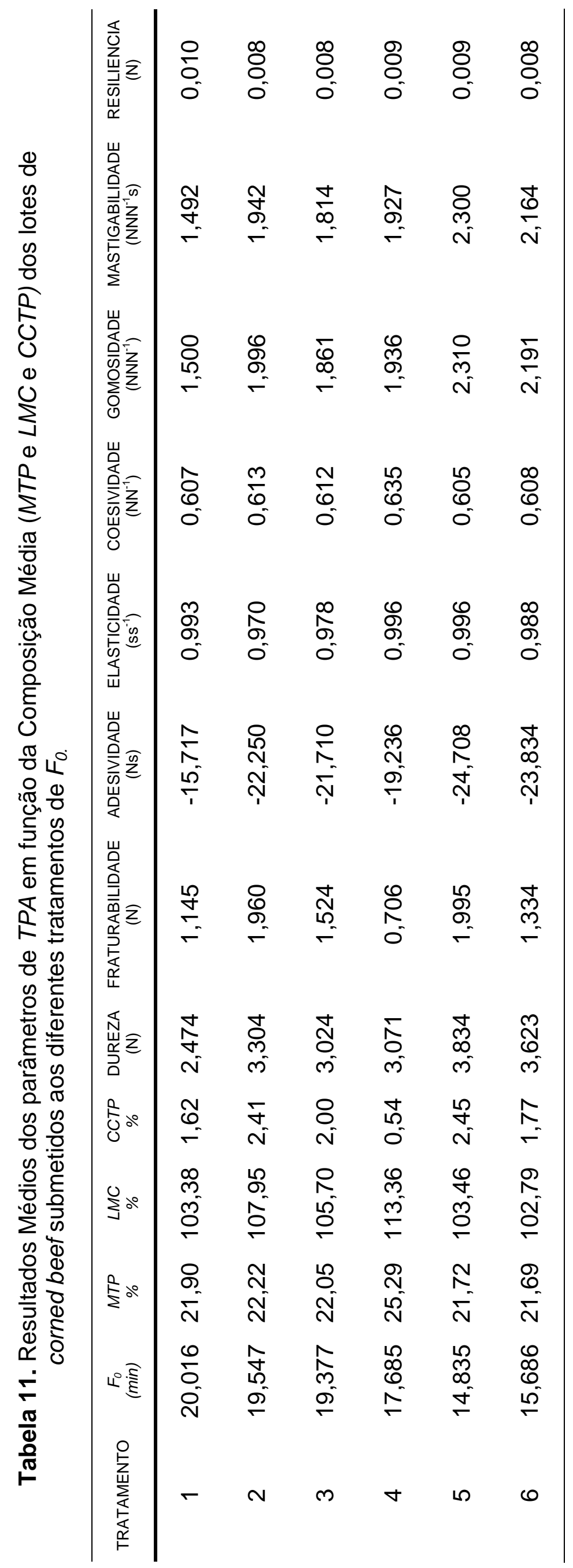




\section{CONCLUSÃO}

O processamento térmico ao qual foram submetidas às amostras de corned beef atingiram valores de esterilização suficientes para a segurança alimentar, no entanto, os valores mostraram-se superdimensionados, influenciando na textura e na qualidade do produto, em termos da dureza, gomosidade, mastigabilidade, adesividade e elasticidade.

Os resultados obtidos nesta pesquisa demonstram que é possível reduzir o tempo de aquecimento no processamento térmico, diminuindo a taxa de ocupação das autoclaves aumentando assim a produtividade da planta com a mesma capacidade instalada, como também a redução de custos por unidade esterilizada, através da economia de energia no processo térmico. Pode-se concluir que a redução da intensidade do tratamento térmico resulta na otimização das propriedades de textura do corned beef alcançando uma graduação de qualidade superior em relação ao mesmo padrão de produto.

A composição do corned beef variou significativamente em relação à MTP (proteína do tecido muscular), CCTP (proteína do tecido conjuntivo colagenoso) e $L M C$ (conteúdo de carne magra), influenciando sobremaneira em diversos parâmetros de textura importantes para a qualidade do produto, como a adesividade e a elasticidade. A coesividade e a fraturabilidade, apesar de não apresentarem diferenças significativas nos tratamentos, mostram também estarem correlacionadas com a composição.

O $L M C$ calculado empregando-se o fator de Stubbs \& More, quando empregado no ajuste dos resultados das análises rápidas da formulação do corned beef, mostrou-se altamente correlacionado com os valores de CCTP e MTP, podendo ser convenientemente aplicados no controle desta etapa do processo para diminuir a amplitude da variação da proteína, podendo reduzir o custo do produto e aumentar a coesividade e reduzir a fraturabilidade.

Os parâmetros de TPA obtidos como a dureza, gomosidade, mastigabilidade, adesividade, e elasticidade que apresentaram diferenças significativas entre os tratamentos, permitiram uma avaliação minuciosa da textura do corned beef por metodologia instrumental, e que por sua vez, permite a associação com a avaliação subjetiva sensorial da textura, e a 
determinação dos parâmetros cinéticos para a otimização do processamento térmico, visando cozimento (textura) e esterilização (microorganismos). 


\section{REFERÊNCIAS}

ALI, A.; SUDHIR, B.; GOPAL, T. K. S. Effect of heat processing on the texture profile of canned and retort pouch packed oil sardine (sardinella longiceps) in oil medium. Jornal of Food Science, Chicago, v. 70, n. 5, p. 350-354, 2005.

BRASIL. Ministério do Desenvolvimento, Indústria e Comércio Exterior. Exportações e importações de carne bovina por países industrializada. Dados emitidos pelo MDIC SECEX DECEX com bases nos registros de exportações NCM 1601.00.00/1602.50.00, Brasília, DF, 2008.

- Ministério da Agricultura. Secretaria Nacional de Defesa Agropecuária. Laboratório Nacional de Referência Animal. Métodos analíticos oficiais para controle de produtos de origem animal e seus ingredientes: II - Métodos físicos e químicos. Brasília, DF, 1981. 122 p.

. Decreto no 4.629, de 21 de março de 2003. Aprova

regulamento técnico de qualidade e identidade de carne bovina em conserva (corned beef). Diário Oficial [da República Federativa do Brasil], Brasília, DF, n. 228, 21 mar. 2003. Seção 1, p. 29.

BELITZ, H. D.; GROSCH, W.; SCHIEBERLE, P. Food chemistry. 4. ed.: Berlin: Springer-Verlag Berlin and Heidelberg GmbH \& Co. KG, 2009. 1070 p.

BERRY, M. R.; PFLUG, I. J. Canning of foods: principles of canning. In: MACRAE, R. (Ed.). Encyclopedia of food science, food technology and nutrition. London: Academic Press, 1993. p. 816-824.

BORSCHÉ, C. E. Get a taste of the future! Space Center Roundup. National Aeronautics and Space Administration, Houston, v. 43, n. 5, p. 8-11, may. 2002. 
CAMPDEN \& CHORELYWOOD FOOD RESEARCH ASSOCIATION (CCFRA). Quality specifications for canned fish and canned meat: corned beef, L49/3. Chipping Campden, Gloucestershire, UK, 2001. p. 12.

CHENG-JIN, D.; DA-WEN, S. Automatic measurement of pores and porosity in pork ham and their correlations with processing time, water content and texture. Meat Science, Champaign, v. 72, n. 2, p. 294-302, 2006.

CENTRE DE LIAISON DES INDUSTRIES TRANSFORMATRICES DE VIANDE DE L'UE (CLITRAVI). Guidance document on the application of Commission. Directive 2001/101 on the definition of meat amending Directive 2000/13. Manuscript. Brussels, 2002.

CODEX ALIMENTARIUS COMMISSION. Recommended international code of practice for low-acid and acidified low-acid canned food: CAC/RCP 23-1979, Rev. 2 (1993), 1979. p. 1-95.

DEASON, G. L.; ABOOT, G. W. Subsistence Meal Ready to Eat (MRE). Executive Research Project RS1. The Industrial College of the Armed Forces. National Defense University. Washington, DC, 1993. p. 31.

DIOS ALVARADO, J.; AGUILERA, J. M. Métodos para medir propriedades físicas en industrias de alimentos. Zaragoza: Editorial Acribia, 2001. 410 p.

DOLATA, W.; PIOTROWSKA, E.; MRÓZ, J. Texture and plasticity of chopped canned meat products as affected by various volumes of water added to the batter. Electronic Journal of Polish Agricultural Universities, Food Science and Technology, Lublin, v. 4, n. 2, p. 1-8, 2001.

EUROPEAN UNION. Commission Regulation (EC) № 1344/2008. Official Journal of the European Union, 23 Dec. 2008. L 348/36.

- Commission Directive 2001/101/EC. Official Journal of the European Union, 26 Nov. 2001. L 124, 66-93. 
GARCÍA SEGÓVIA, P.; ANDRÉS BELLO.; MARTÍNEZ MONZÓ, J. Effect of cooking method on mechanical properties, color and structure of beef muscle (M. pectoralis). Journal of Food Engineering, Pullman, v. 80, n. 3, p. 813821, 2007.

GUIMARÃES, J. L.; ADELL, E. A.; FELíCIO, P. E. Estrutura e composição do músculo e tecidos associados. Campinas: Laboratório de Carnes DTA FEA UNICAMP, 1995. p.13. Apostila.

GUMERATO, H. F. Estudo da transferência de calor transiente por agitação intermitente em embalagens. 2004. 118 f. Tese (Doutorado)Programa de Pós-Graduação em Agronomia, Faculdade de Ciências Agronômicas, Universidade Estadual Paulista, Botucatu, 2004.

HORVATH, S. Swift lança marca e ingressa no mercado de sopas individuais. Gazeta Mercantil, São Paulo, 31 jul. 2008. Caderno C, p. 4.

HOLDWORTH, D.; SIMPSON, R. Thermal processing of packaged foods. 2. ed. Springer: Washington, 2008. $407 \mathrm{p}$.

JUN, S.; COX, L. J.; HUANG, A. Using the flexible retort pouch to add value to agricultural products. Honolulu: University of Hawai'i at Mänoa, 2006. p. 1-6. (Food Safety and Technology, FST-18)

LANTTO, R. Protein cross-linking with oxidative enzymes and transglutaminase: effects in meat protein systems. 2007. 114 f. Dissertação (Mestrado), Department of Food Technology, University of Helsinki, Helsinki, Finland, 2007.

OFFICIAL methods of analysis of AOAC International. 18. ed. Maryland: Association of Official Analytical Chemists; 2009.

POPPE, J. Thickening and geling agents for foods. 2. ed. Londres: Blackie Academic \& Professional; 1997. 320 p. 
PALKA, K. Changes in intramuscular connective tissue and collagen solubility of bovine $\mathrm{m}$. semitendinosus during retorting. Meat Science, Champaign, v. 53, n.3, p. 189-194, 1999.

; DAUN, H. Changes in texture, cooking losses, and myofibrillar structure of bovine M. semitendinosus during heating. Meat Science, Champaign, v. 51, n. 3, p. 237-243, 1999.

PATASHNIK, M. A. Simplified procedure for thermal process evaluation. Food Technology, Chicago, v. 7, n. 1, p. 1-16, 1953.

RANKEN, M. D.; KILL, R. C.; BAKER, C. C. J. Food industries manual (Leatherhead Food Reseach Association). 24. ed. Londres: Blackie Academic \& Professional, 1993, p. 638.

RHA, C. Thermal sterilization of flexibly packaged foods. 1967. $179 \mathrm{f}$. Tese (Doutorado), Massachusetts Institute of Technology, Massachusetts, 1967.

SACHAROW, S. Is the retort pouch really ready to replace the metal can? Chicago: Paper, Film \& Foil Converter, Apr. 2003. Disponível em: <http://pffconline.com/flex_pack/paper_retort_pouch_really/index.html>. Acesso em: 21 jul. 2007.

Pouch progress. Chicago: Paper, Film \& Foil Converter, Jan. 2007. Disponível em: $<$ http://pffconline.com/flex_pack/paper_pouch_progress/index.html. Acesso em: 12 ago. 2007.

SARANTÓPOULOS, C. I. G. L. et al. Embalagens plásticas flexíveis: principais polímeros e avaliação de propriedades. Campinas: CETEA/ITAL, 2002. $267 \mathrm{p}$. 
SHEHATA, H. A.; SHALABY, M. T.; HASSAN, A. M. Gelatin and some other natural thickening agents for use in canned corned beef. Journal of Food Science Technology, Oxford, v. 31, n. 4, p. 298-301, 1994.

SIMPSON, R.; ALMONACID, S.; MITCHELL, M. Mathematical model development, experimental validation and process optimization: retortable pouches packed with seafood in cone frustum shape. Journal of Food Engineering, Pullman, v. 63, n. 2, p. 153-162, 2004.

; CORTÉS, C.; TEIXEIRA, A. Energy consumption in batch thermal processing: model development and validation. Journal of Food Engineering, Pullman, v. 73, n. 3, p. 217-224, 2006.

STUMBO, C. R. Thermo bacteriology in food processing. 2. ed. Londres: Academic Press, 1973. 329 p.

TARTÉ, R. Ingredients in meat products: properties, functionality and applications. New York: Springer, 2008. 419 p.

UNITED STATES OF AMERICA. Food and Drug Administration. Principles of thermal processing. Food Safety Regulatory Essentials (FSRE), Rockville, 2005.

. United States Department of Agriculture. Corned beef and food safety. Food Safety Information, 2008. Disponível em: <http://www.fsis.usda.gov/FactSheets/Corned_Beef/index.asp>. Acesso em: 12 jul. 2008.

VERBEKEN, D. et al. Influence of k-carrageenan on the thermal gelation of salt-soluble meat proteins. Meat Science, Champaign, v. 70, n. 1, p. 161-166, 2005.

WEBB, E. L. Process control parameters for Skipjack tuna (Katsuwonas pelamis) precooking. 2003. 154 f. Tese (Doutorado). Department of 
Biological and Agricultural Engineering, North Carolina State University, Raleigh, 2003.

WILLIAMS, J. F.; STEFFE J. F.; BLACK J. R. Economic comparison of canning and retort pouch systems. Journal of Food Science, Chicago, v. 47, n. 1, p. 284-290, 1982.

ZUKÁL, E.; KÖRMENDY, L. On calculation of 'meat content' according to the quantitative ingredient declarations (QUID). Journal of Food Engineering, Pullman, v. 78, n. 2, p. 614-621, 2007. 


\section{Anexo 1. Análises por métodos rápidos da composição dos lotes do misturador na preparação do corned beef}

A determinação da composição das bateladas do misturador para 0 controle estatístico do processo realizado pela indústria consistiu na determinação da umidade e dos lipídeos e o cálculo da proteína por diferença. Foram utilizados os métodos analíticos rápidos de acordo com os métodos oficiais de análise da Association of Official Analytical Chemists AOAC e os métodos analíticos oficiais para controle de produtos de origem animal e seus ingredientes do Laboratório Nacional de Referência Animal LANARA (BRASIL, 1981; AOAC, 2009).

A determinação da umidade foi realizada por gravimetria baseada na perda de umidade em um forno de microondas. Foram pesadas $5 \mathrm{~g}$ de amostras em placa de Petri e dessecadas durante 3 minutos com potência $80 \%$ conforme o método AOAC 985.14. Os resultados foram expressos em g água $g$ total $^{-1}$ (AOAC, 2009).

Os lipídeos foram determinados através da hidrólise da matéria orgânica pelo ácido sulfúrico e preservação dos lipídios, os quais podem ser separados com o álcool isoamílico, para diminuir a tensão superficial, seguido de centrifugação. Foram pesadas $3 \mathrm{~g}$ de amostras em béquer de $50 \mathrm{ml}$ e adicionados $4 \mathrm{ml}$ de água destilada a $60^{\circ} \mathrm{C}$ e em seguida feita a homogeneização da mistura. Adicionou-se cuidadosamente à mistura 7 $\mathrm{ml}$ de ácido sulfúrico densidade $1,820 \mathrm{~g} \mathrm{~cm}^{-3}$, homogeneizando-a com um bastão de vidro até a digestão de todos os pedaços de carne. O hidrolisado foi transferido para o butirômetro de Gerber, lavando-se o béquer com $4 \mathrm{ml}$ de água quente e $3 \mathrm{ml}$ de solução de ácido sulfúrico densidade $1,820 \mathrm{~g} \mathrm{~cm}^{-3}$ e acrescentando-se $1 \mathrm{ml}$ de álcool isoamílico. $\mathrm{O}$ butirômetro foi fechado com rolha de borracha e mantido em banho térmico a $65^{\circ} \mathrm{C}$ por 10 minutos. Em seguida centrifugado a $1500 \mathrm{rpm}$ por 5 minutos em centrífuga de Gerber. A leitura feita em mililitros de gordura diretamente na escala do butirômetro e calculado o teor de gordura, expressado em $\mathrm{g}$ lipídeos $\mathrm{g}_{\text {total }}{ }^{-1}$ (BRASIL, 1981).

O conteúdo de proteína foi calculado por diferença somando-se os valores de umidade, de lipídeos, de sal adicionado e de açúcar 
adicionado e subtraindo-se o resultado da soma de $100 \%$ menos o fator de correção de $0,3 \%$ utilizado pela indústria, conforme a Equação 10.

\%proteína $=(100 \%-0,3 \%)-(\%$ umidade $+\%$ lipídeos $+2,2 \%$ sal $+1 \%$ açúcar $)(10)$

O Conteúdo Total de Carne (TMC) foi calculado somando-se o $L M C$ (dividindo o Nitrogênio total pelo fator 3,65 de Stubbs \& More) ao teor de lipídeos.

Os valores obtidos pelos métodos rápidos de análise realizadas na planta encontram-se nas Tabelas de 1 a 5 seguintes. Estes foram ajustados conforme os resultados da composição centesimal completa das amostras utilizadas nesta pesquisa (Tabela 7 do item 6.3) e da proteína calculada segundo a Equação 11. Este ajuste foi fundamentado no fato da indústria, usualmente, não considerar nos cálculos os carboidratos presentes nas carnes (glicogênio muscular) e também o resíduo mineral fixo e sim apenas o percentual de sacarose adicionada e um percentual fixo para o cloreto de sódio. A diferença entre o valor médio determinado para cinzas $2,69 \% \pm 0,07$ (Tabela 7) e o cloreto de sódio adicionado $2,20 \%$ foi de $0,48 \%$ e a diferença entre o valor médio determinado para os carboidratos 2,09\% $\pm 0,13$ (Tabela 7) e a sacarose real adicionada $1 \%$ foi de $1,09 \%$. Somando estas diferenças obtém-se um fator de correção de 1,57 para as análises rápidas realizadas na planta para esse padrão de corned beef. Os percentuais de cloreto de sódio e sacarose adicionados nos lotes de mistura (Tabela 2 do item 5.1) foram fixos e sempre ajustados de acordo com a fórmula base, sempre que havia acréscimo de gordura ou carne magra para correção da batelada no misturador. Considerando-se os valores médios e o erro padrão da média de carboidratos e cinzas do corned beef do mesmo padrão analisado nesta pesquisa, pode-se utilizar a Equação 11 para ajuste dos resultados das análises rápidas na planta industrial. $O \angle M C$ foi calculado, dividindo-se o nitrogênio total (teor de proteína dividido pelo fator de conversão nitrogênio carne 6,25) por 3,65 (Stubbs \& More fator) e sendo a "Proteína Total da Carne" (TMC) calculada por diferença 
(Equação 10), os valores das análises químicas rápidas ajustadas permitem uma maior precisão na determinação do $L M C$ para o controle estatístico do processo de mistura (ajuste da formulação) através de

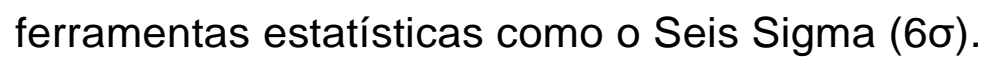

\%Proteína Ajustada $=(100$ - 1,57)\% - (\%umidade +\%lipídeos +\%sal +\%açúcar $)(11)$ 
Tabela 1. Análises rápidas da composição dos lotes do misturador na preparação do corned beef dos tratamentos 1 e 2.

\begin{tabular}{|c|c|c|c|c|c|c|c|c|c|c|}
\hline Lotes & 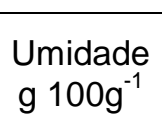 & $\begin{array}{l}\text { Lipídeos } \\
\text { g } 100 \mathrm{~g}^{-1}\end{array}$ & $\begin{array}{l}\text { Sal } \\
\%\end{array}$ & $\begin{array}{c}\text { Açúcar } \\
\%\end{array}$ & 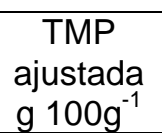 & $\begin{array}{c}\text { TMP } \\
\mathrm{g} 100 \mathrm{~g}^{-1}\end{array}$ & $\begin{array}{c}\text { LMC } \\
\text { ajustado } \\
\%\end{array}$ & $\begin{array}{c}\mathrm{LMC} \\
\%\end{array}$ & $\begin{array}{c}\text { TMC } \\
\text { ajustado } \\
\%\end{array}$ & $\begin{array}{c}\text { TMC } \\
\%\end{array}$ \\
\hline 1 & 56,17 & 15,24 & 2,20 & 1,00 & 23,82 & 25,09 & 104,41 & 109,98 & 119,65 & 125,22 \\
\hline 2 & 57,35 & 13,18 & 2,20 & 1,00 & 24,70 & 25,97 & 108,26 & 113,84 & 121,44 & 127,02 \\
\hline 3 & 58,16 & 11,94 & 2,20 & 1,00 & 25,13 & 26,40 & 110,15 & 115,73 & 122,09 & 127,67 \\
\hline 4 & 58,34 & 12,36 & 2,20 & 1,00 & 24,53 & 25,80 & 107,52 & 113,10 & 119,88 & 125,46 \\
\hline 5 & 56,50 & 14,42 & 2,20 & 1,00 & 24,31 & 25,58 & 106,55 & 112,13 & 120,97 & 126,55 \\
\hline 6 & 56,73 & 14,00 & 2,20 & 1,00 & 24,50 & 25,77 & 107,39 & 112,96 & 121,39 & 126,96 \\
\hline 7 & 55,52 & 15,24 & 2,20 & 1,00 & 24,47 & 25,74 & 107,26 & 112,83 & 122,50 & 128,07 \\
\hline 8 & 54,82 & 15,24 & 2,20 & 1,00 & 25,17 & 26,44 & 110,32 & 115,90 & 125,56 & 131,14 \\
\hline 9 & 58,53 & 11,12 & 2,20 & 1,00 & 25,58 & 26,85 & 112,12 & 117,70 & 123,24 & 128,82 \\
\hline 10 & 59,83 & 10,30 & 2,20 & 1,00 & 25,10 & 26,37 & 110,02 & 115,59 & 120,32 & 125,89 \\
\hline 11 & 59,81 & 10,30 & 2,20 & 1,00 & 25,12 & 26,39 & 110,11 & 115,68 & 120,41 & 125,98 \\
\hline 12 & 60,00 & 10,30 & 2,20 & 1,00 & 24,93 & 26,20 & 109,27 & 114,85 & 119,57 & 125,15 \\
\hline 13 & 58,42 & 11,12 & 2,20 & 1,00 & 25,69 & 26,96 & 112,60 & 118,18 & 123,72 & 129,30 \\
\hline 14 & 60,14 & 10,30 & 2,20 & 1,00 & 24,79 & 26,06 & 108,66 & 114,24 & 118,96 & 124,54 \\
\hline 15 & 59,36 & 12,36 & 2,20 & 1,00 & 23,51 & 24,78 & 103,05 & 108,62 & 115,41 & 120,98 \\
\hline 16 & 59,09 & 11,53 & 2,20 & 1,00 & 24,61 & 25,88 & 107,87 & 113,45 & 119,40 & 124,98 \\
\hline 17 & 60,41 & 10,71 & 2,20 & 1,00 & 24,11 & 25,38 & 105,68 & 111,25 & 116,39 & 121,96 \\
\hline 18 & 57,77 & 12,77 & 2,20 & 1,00 & 24,69 & 25,96 & 108,22 & 113,80 & 120,99 & 126,57 \\
\hline 19 & 58,02 & 10,30 & 2,20 & 1,00 & 26,91 & 28,18 & 117,95 & 123,53 & 128,25 & 133,83 \\
\hline 20 & 59,09 & 11,53 & 2,20 & 1,00 & 24,61 & 25,88 & 107,87 & 113,45 & 119,40 & 124,98 \\
\hline 21 & 58,57 & 10,30 & 2,20 & 1,00 & 26,36 & 27,63 & 115,54 & 121,12 & 125,84 & 131,42 \\
\hline 22 & 59,16 & 12,36 & 2,20 & 1,00 & 23,71 & 24,98 & 103,92 & 109,50 & 116,28 & 121,86 \\
\hline 23 & 60,59 & 11,12 & 2,20 & 1,00 & 23,52 & 24,79 & 103,09 & 108,67 & 114,21 & 119,79 \\
\hline 24 & 60,32 & 11,53 & 2,20 & 1,00 & 23,38 & 24,65 & 102,48 & 108,05 & 114,01 & 119,58 \\
\hline 25 & 58,71 & 11,94 & 2,20 & 1,00 & 24,58 & 25,85 & 107,74 & 113,32 & 119,68 & 125,26 \\
\hline 26 & 60,76 & 11,12 & 2,20 & 1,00 & 23,35 & 24,62 & 102,35 & 107,92 & 113,47 & 119,04 \\
\hline 27 & 60,83 & 11,53 & 2,20 & 1,00 & 22,87 & 24,14 & 100,24 & 105,82 & 111,77 & 117,35 \\
\hline 28 & 58,57 & 12,36 & 2,20 & 1,00 & 24,30 & 25,57 & 106,51 & 112,09 & 118,87 & 124,45 \\
\hline 29 & 60,96 & 10,71 & 2,20 & 1,00 & 23,56 & 24,83 & 103,27 & 108,84 & 113,98 & 119,55 \\
\hline 30 & 61,08 & 10,71 & 2,20 & 1,00 & 23,44 & 24,71 & 102,74 & 108,32 & 113,45 & 119,03 \\
\hline 31 & 59,05 & 12,36 & 2,20 & 1,00 & 23,82 & 25,09 & 104,41 & 109,98 & 116,77 & 122,34 \\
\hline 32 & 59,55 & 12,36 & 2,20 & 1,00 & 23,32 & 24,59 & 102,21 & 107,79 & 114,57 & 120,15 \\
\hline 33 & 59,46 & 11,94 & 2,20 & 1,00 & 23,83 & 25,10 & 104,45 & 110,03 & 116,39 & 121,97 \\
\hline 34 & 57,53 & 10,71 & 2,20 & 1,00 & 26,99 & 28,26 & 118,30 & 123,88 & 129,01 & 134,59 \\
\hline 35 & 59,72 & 10,30 & 2,20 & 1,00 & 25,21 & 26,48 & 110,50 & 116,08 & 120,80 & 126,38 \\
\hline
\end{tabular}


Tabela 1. Análises rápidas da composição dos lotes do misturador na preparação do corned beef dos tratamentos 1 e 2 (continuação).

\begin{tabular}{ccccccccccc}
\hline Lotes & $\begin{array}{c}\text { Umidade } \\
\text { g } 100 \mathrm{~g}^{-1}\end{array}$ & $\begin{array}{c}\text { Lipídeos }_{\mathrm{g} 100 \mathrm{~g}^{-1}} \\
\text { \% }\end{array}$ & $\begin{array}{c}\text { Açúcar } \\
\%\end{array}$ & $\begin{array}{c}\text { TMP } \\
\text { ajustada } \\
\mathrm{g} 100 \mathrm{~g}^{-1}\end{array}$ & $\begin{array}{c}\text { TMP } \\
\mathrm{g} 100 \mathrm{~g}^{-1}\end{array}$ & $\begin{array}{c}\text { LMC } \\
\text { ajustado } \\
\%\end{array}$ & $\begin{array}{c}\text { LMC } \\
\%\end{array}$ & $\begin{array}{c}\text { TMC } \\
\text { ajustado } \\
\%\end{array}$ & $\begin{array}{c}\text { TMC } \\
\%\end{array}$ \\
\hline 36 & 60,10 & 11,12 & 2,20 & 1,00 & 24,01 & 25,28 & 105,24 & 110,82 & 116,36 & 121,94 \\
37 & 59,45 & 11,94 & 2,20 & 1,00 & 23,84 & 25,11 & 104,49 & 110,07 & 116,43 & 122,01 \\
38 & 61,39 & 10,30 & 2,20 & 1,00 & 23,54 & 24,81 & 103,18 & 108,76 & 113,48 & 119,06 \\
39 & 57,69 & 14,42 & 2,20 & 1,00 & 23,12 & 24,39 & 101,34 & 106,92 & 115,76 & 121,34 \\
40 & 60,31 & 11,53 & 2,20 & 1,00 & 23,39 & 24,66 & 102,52 & 108,10 & 114,05 & 119,63 \\
41 & 59,36 & 11,12 & 2,20 & 1,00 & 24,75 & 26,02 & 108,48 & 114,06 & 119,60 & 125,18 \\
42 & 60,53 & 10,30 & 2,20 & 1,00 & 24,40 & 25,67 & 106,95 & 112,53 & 117,25 & 122,83 \\
43 & 60,55 & 11,53 & 2,20 & 1,00 & 23,15 & 24,42 & 101,47 & 107,05 & 113,00 & 118,58 \\
44 & 61,77 & 10,30 & 2,20 & 1,00 & 23,16 & 24,43 & 101,51 & 107,09 & 111,81 & 117,39 \\
45 & 60,05 & 10,30 & 2,20 & 1,00 & 24,88 & 26,15 & 109,05 & 114,63 & 119,35 & 124,93 \\
46 & 58,12 & 11,94 & 2,20 & 1,00 & 25,17 & 26,44 & 110,32 & 115,90 & 122,26 & 127,84 \\
47 & 60,50 & 10,30 & 2,20 & 1,00 & 24,43 & 25,70 & 107,08 & 112,66 & 117,38 & 122,96 \\
48 & 59,77 & 10,71 & 2,20 & 1,00 & 24,75 & 26,02 & 108,48 & 114,06 & 119,19 & 124,77 \\
49 & 61,79 & 12,36 & 2,20 & 1,00 & 21,08 & 22,35 & 92,40 & 97,97 & 104,76 & 110,33 \\
50 & 60,79 & 14,00 & 2,20 & 1,00 & 20,44 & 21,71 & 89,59 & 95,17 & 103,59 & 109,17 \\
51 & 60,56 & 14,00 & 2,20 & 1,00 & 20,67 & 21,94 & 90,60 & 96,18 & 104,60 & 110,18 \\
52 & 62,13 & 11,12 & 2,20 & 1,00 & 21,98 & 23,25 & 96,34 & 101,92 & 107,46 & 113,04 \\
53 & 61,29 & 12,77 & 2,20 & 1,00 & 21,17 & 22,44 & 92,79 & 98,37 & 105,56 & 111,14 \\
54 & 62,80 & 11,53 & 2,20 & 1,00 & 20,90 & 22,17 & 91,61 & 97,18 & 103,14 & 108,71 \\
MÉDIA & 59,41 & 11,80 & 2,20 & 1,00 & 24,02 & 25,30 & 105,31 & 110,88 & 117,11 & 122,68 \\
DP & 1,66 & 1,42 & 0,00 & 0,00 & 1,40 & 1,40 & 6,12 & 6,12 & 5,85 & 5,85 \\
\hline & & & & & & & & & & \\
4
\end{tabular}


Tabela 2. Análises rápidas da composição dos lotes do misturador na preparação do corned beef do tratamento 3 .

\begin{tabular}{|c|c|c|c|c|c|c|c|c|c|c|}
\hline Lotes & 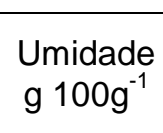 & $\begin{array}{l}\text { Lipídeos } \\
\text { g } 100 \mathrm{~g}^{-1}\end{array}$ & $\begin{array}{l}\text { Sal } \\
\%\end{array}$ & $\begin{array}{c}\text { Açúcar } \\
\%\end{array}$ & 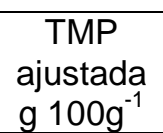 & $\begin{array}{c}\text { TMP } \\
\mathrm{g} 100 \mathrm{~g}^{-1}\end{array}$ & $\begin{array}{c}\text { LMC } \\
\text { ajustado } \\
\%\end{array}$ & $\begin{array}{c}\mathrm{LMC} \\
\%\end{array}$ & $\begin{array}{c}\text { TMC } \\
\text { ajustado } \\
\%\end{array}$ & $\begin{array}{c}\text { TMC } \\
\%\end{array}$ \\
\hline 1 & 58,83 & 11,94 & 2,20 & 1,00 & 24,46 & 25,73 & 107,21 & 112,79 & 119,15 & 124,73 \\
\hline 2 & 58,83 & 11,94 & 2,20 & 1,00 & 24,46 & 25,73 & 107,21 & 112,79 & 119,15 & 124,73 \\
\hline 3 & 58,97 & 11,53 & 2,20 & 1,00 & 24,73 & 26,00 & 108,40 & 113,97 & 119,93 & 125,50 \\
\hline 4 & 59,97 & 10,30 & 2,20 & 1,00 & 24,96 & 26,23 & 109,40 & 114,98 & 119,70 & 125,28 \\
\hline 5 & 58,73 & 10,71 & 2,20 & 1,00 & 25,79 & 27,06 & 113,04 & 118,62 & 123,75 & 129,33 \\
\hline 6 & 59,63 & 10,30 & 2,20 & 1,00 & 25,30 & 26,57 & 110,89 & 116,47 & 121,19 & 126,77 \\
\hline 7 & 59,86 & 10,30 & 2,20 & 1,00 & 25,07 & 26,34 & 109,89 & 115,46 & 120,19 & 125,76 \\
\hline 8 & 60,92 & 10,30 & 2,20 & 1,00 & 24,01 & 25,28 & 105,24 & 110,82 & 115,54 & 121,12 \\
\hline 9 & 59,31 & 71 & 2,20 & 1,00 & 25,21 & 26,48 & 110,50 & 116,08 & 121,21 & 126,79 \\
\hline 10 & 58,84 & 30 & 2,20 & 1,00 & 26,09 & 27,36 & 114,36 & 119,93 & 124,66 & 130,23 \\
\hline 11 & 57,43 & 42 & 2,20 & 1,00 & 23,38 & 24,65 & 102,48 & 108,05 & 116,90 & 122,47 \\
\hline 12 & 60,05 & 53 & 2,20 & 1,00 & 23,65 & 24,92 & 103,66 & 109,24 & 115,19 & 120,77 \\
\hline 13 & 60,38 & ,30 & 2,20 & 1,00 & 24,55 & 25,82 & 107,61 & 113,18 & 117,91 & 123,48 \\
\hline 14 & 60,31 & 10,30 & 2,20 & 1,00 & 24,62 & 25,89 & 107,91 & 113,49 & 118,21 & 123,79 \\
\hline 15 & 58,47 & 11,94 & 2,20 & 1,00 & 24,82 & 26,09 & 108,81 & 114,37 & 120,75 & 126,31 \\
\hline 16 & 59,65 & 10,30 & 2,20 & 1,00 & 25,28 & 26,55 & 110,81 & 116,38 & 121,11 & 126,68 \\
\hline 17 & 56,91 & 13,18 & 2,20 & 1,00 & 25,14 & 26,41 & 110,19 & 115,77 & 123,37 & 128,95 \\
\hline 18 & 59,43 & 11,12 & 2,20 & 1,00 & 24,68 & 25,95 & 108,18 & 113,75 & 119,30 & 124,87 \\
\hline 19 & 57,47 & 13,18 & 2,20 & 1,00 & 24,58 & 25,85 & 107,74 & 113,32 & 120,92 & 126,50 \\
\hline 20 & 59,77 & 10,71 & 2,20 & 1,00 & 24,75 & 26,02 & 108,48 & 114,06 & 119,19 & 124,77 \\
\hline 21 & 59,31 & 11,94 & 2,20 & 1,00 & 23,98 & 25,25 & 105,11 & 110,68 & 117,05 & 122,62 \\
\hline 22 & 59,35 & 11,94 & 2,20 & 1,00 & 23,94 & 25,21 & 104,93 & 110,51 & 116,87 & 122,45 \\
\hline 23 & 60,52 & 12 & 2,20 & 1,00 & 23,59 & 24,86 & 103,40 & 108,98 & 114,52 & 120,10 \\
\hline 24 & 61,85 & 10,30 & 2,20 & 1,00 & 23,08 & 24,35 & 101,16 & 106,74 & 111,46 & 117,04 \\
\hline 25 & 60,30 & 11,53 & 2,20 & 1,00 & 23,40 & 24,67 & 102,57 & 108,14 & 114,10 & 119,67 \\
\hline 26 & 59,29 & 11,12 & 2,20 & 1,00 & 24,82 & 26,09 & 108,79 & 114,37 & 119,91 & 125,49 \\
\hline 27 & 60,30 & 11,53 & 2,20 & 1,00 & 23,40 & 24,67 & 102,57 & 108,14 & 114,10 & 119,67 \\
\hline 28 & 59,20 & 12,36 & 2,20 & 1,00 & 23,67 & 24,94 & 103,75 & 109,33 & 116,11 & 121,69 \\
\hline 29 & 58,05 & 12,36 & 2,20 & 1,00 & 24,82 & 26,09 & 108,79 & 114,37 & 121,15 & 126,73 \\
\hline 30 & 58,99 & 11,12 & 2,20 & 1,00 & 25,12 & 26,39 & 110,11 & 115,68 & 121,23 & 126,80 \\
\hline 31 & 58,13 & 11,12 & 2,20 & 1,00 & 25,98 & 27,25 & 113,87 & 119,45 & 124,99 & 130,57 \\
\hline 32 & 57,67 & 11,94 & 2,20 & 1,00 & 25,62 & 26,89 & 112,30 & 117,87 & 124,24 & 129,81 \\
\hline 33 & 59,47 & 10,30 & 2,20 & 1,00 & 25,46 & 26,73 & 111,60 & 117,17 & 121,90 & 127,47 \\
\hline 34 & 60,47 & 10,30 & 2,20 & 1,00 & 24,46 & 25,73 & 107,21 & 112,79 & 117,51 & 123,09 \\
\hline 35 & 59,21 & 10,30 & 2,20 & 1,00 & 25,72 & 26,99 & 112,74 & 118,31 & 123,04 & 128,61 \\
\hline 36 & 59,23 & 11,94 & 2,20 & 1,00 & 24,06 & 25,33 & 105,47 & 111,04 & 117,41 & 122,98 \\
\hline 37 & 58,04 & 59 & 2,20 & 1,00 & 23,60 & 24,87 & 103,44 & 109,02 & 117,03 & 122,61 \\
\hline 38 & 57,52 & 14,00 & 2,20 & 1,00 & 23,71 & 24,98 & 103,92 & 109,50 & 117,92 & 123,50 \\
\hline 39 & 58,77 & 13,18 & 2,20 & 1,00 & 23,28 & 24,55 & 102,04 & 107,62 & 115,22 & 120,80 \\
\hline 40 & 58, & & 2,20 & $1, \mathrm{C}$ & 23,55 & 24,82 & 103,22 & 108 & 115,99 & 121,57 \\
\hline 41 & 59,3 & & 2,18 & $0, \subseteq$ & 23,18 & 24, & 101,63 & 107,09 & 114,40 & 119,86 \\
\hline 42 & 58,17 & & 2,20 & 1,0 & 23,88 & 25,15 & 104,67 & 110,25 & 117,85 & 123,43 \\
\hline 43 & 59,02 & 12,36 & 2,20 & 1,00 & 23,85 & 25,12 & 104,54 & 110,12 & 116,90 & 122,48 \\
\hline 44 & 58,44 & 11,53 & 2,20 & 1,00 & 25,26 & 26,53 & 110,72 & 116,30 & 122,25 & 127,83 \\
\hline 45 & 58,73 & 12,36 & 2,20 & 1,00 & 24,14 & 25,41 & 105,81 & 111,39 & 118,17 & 123,75 \\
\hline 46 & 57,43 & 10,71 & 2,20 & 1,00 & 27,09 & 28,36 & 118,74 & 124,32 & 129,45 & 135,03 \\
\hline 47 & 56,65 & 13,18 & 2,20 & 1,00 & 25,40 & 26,67 & 111,33 & 116,91 & 124,51 & 130,09 \\
\hline
\end{tabular}


Tabela 2. Análises rápidas da composição dos lotes do misturador na preparação do corned beef do tratamento 3 (continuação).

\begin{tabular}{|c|c|c|c|c|c|c|c|c|c|c|}
\hline Lotes & 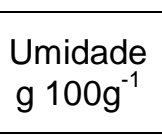 & $\begin{array}{l}\text { Lipídeos } \\
\text { g } 100 \mathrm{~g}^{-1}\end{array}$ & $\begin{array}{l}\text { Sal } \\
\%\end{array}$ & $\begin{array}{c}\text { Açúcar } \\
\%\end{array}$ & 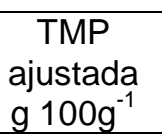 & $\begin{array}{c}\text { TMP } \\
\mathrm{g} 100 \mathrm{~g}^{-1}\end{array}$ & $\begin{array}{c}\text { LMC } \\
\text { ajustado } \\
\% \\
\end{array}$ & $\begin{array}{c}\mathrm{LMC} \\
\%\end{array}$ & $\begin{array}{c}\text { TMC } \\
\text { ajustado } \\
\% \\
\end{array}$ & $\begin{array}{c}\text { TMC } \\
\%\end{array}$ \\
\hline 48 & 58,97 & 12,36 & 2,20 & 1,00 & 23,90 & 25,17 & 104,76 & 110,33 & 117,12 & 122,69 \\
\hline 49 & 61,59 & 9,88 & 2,20 & 1,00 & 23,76 & 25,03 & 104,14 & 109,72 & 114,02 & 119,60 \\
\hline 50 & 61,69 & 9,47 & 2,20 & 1,00 & 24,07 & 25,34 & 105,50 & 111,08 & 114,97 & 120,55 \\
\hline 51 & 60,63 & 10,30 & 2,20 & 1,00 & 24,30 & 25,57 & 106,51 & 112,09 & 116,81 & 122,39 \\
\hline 52 & 59,03 & 10,30 & 2,20 & 1,00 & 25,90 & 27,17 & 113,52 & 119,10 & 123,82 & 129,40 \\
\hline 53 & 58,43 & 12,77 & 2,20 & 1,00 & 24,03 & 25,30 & 105,33 & 110,90 & 118,10 & 123,67 \\
\hline 54 & 60,22 & 10,30 & 2,20 & 1,00 & 24,71 & 25,98 & 108,31 & 113,88 & 118,61 & 124,18 \\
\hline 55 & 59,32 & 10,30 & 2,20 & 1,00 & 25,61 & 26,88 & 112,25 & 117,83 & 122,55 & 128,13 \\
\hline 56 & 58,06 & 11,94 & 2,20 & 1,00 & 25,23 & 26,50 & 110,59 & 116,16 & 122,53 & 128,10 \\
\hline 57 & 59,75 & 10,30 & 2,20 & 1,00 & 25,18 & 26,45 & 110,37 & 115,95 & 120,67 & 126,25 \\
\hline 58 & 60,69 & 9,47 & 2,20 & 1,00 & 25,07 & 26,34 & 109,89 & 115,46 & 119,36 & 124,93 \\
\hline 59 & 60,55 & 10,30 & 2,20 & 1,00 & 24,38 & 25,65 & 106,86 & 112,44 & 117,16 & 122,74 \\
\hline 60 & 60,43 & 10,30 & 2,20 & 1,00 & 24,50 & & 107,39 & 112,96 & 117,69 & 123,26 \\
\hline 61 & 59,76 & 11,12 & 2,20 & 1,00 & 24,35 & 25,62 & 106,73 & 112,31 & 117,85 & 123,43 \\
\hline 62 & 58,46 & 11,94 & 2,20 & 1,00 & 24,83 & 26,10 & 108,83 & 114,41 & 120,77 & 126,35 \\
\hline 63 & 58,88 & 12,77 & 2,20 & 1,00 & 23,58 & 24,85 & 103,35 & 108,93 & 116,12 & 121,70 \\
\hline 64 & 59,83 & 10,71 & 2,20 & 1,00 & 24,69 & 25,96 & 108,22 & 113,80 & 118,93 & 124,51 \\
\hline 65 & 60,61 & 10,71 & 2,20 & 1,00 & 23,91 & 25,18 & 104,82 & 110,38 & 115,53 & 121,09 \\
\hline 66 & 61,16 & 9,88 & 2,20 & 1,00 & 24,19 & 25,46 & 106,03 & 111,61 & 115,91 & 121,49 \\
\hline 67 & 59,04 & 10,71 & 2,20 & 1,00 & 25,48 & 26,75 & 111,68 & 117,26 & 122,39 & 127,97 \\
\hline 68 & 58,21 & 12,77 & 2,20 & 1,00 & 24,25 & 25,52 & 106,29 & 111,87 & 119,06 & 124,64 \\
\hline 69 & 58,41 & 10,71 & 2,20 & 1,00 & 26,11 & 27,38 & 114,44 & 120,02 & 125,15 & 130,73 \\
\hline 70 & 57,52 & 12,77 & 2,20 & 1,00 & 24,94 & 26,21 & 109,32 & 114,89 & 122,09 & 127,66 \\
\hline 71 & 58,92 & & 2,20 & 1,00 & 26,01 & 27,28 & 114,01 & & 124,31 & 129,88 \\
\hline 72 & 60,29 & 11,12 & 2,20 & 1,0 & 23,82 & & 104,41 & & 115,53 & 121,10 \\
\hline 73 & 60,55 & & 2,20 & 1,0 & 24,80 & 26,07 & 108,70 & 114,28 & 118,58 & 124,16 \\
\hline 74 & 60,20 & 10,30 & 2,20 & 1,00 & 24,73 & 26,00 & 108,40 & 113,97 & 118,70 & 124,27 \\
\hline 75 & & & 2,20 & & 25,04 & & 109,75 & & 120,05 & 125,63 \\
\hline 76 & 59,2 & & 2,20 & & 24,83 & & 108,83 & 11 & 119,95 & 125,53 \\
\hline 77 & $60, \varepsilon$ & & 2,20 & 1, & 24,04 & & 105,37 & 5 & 115,67 & 121,25 \\
\hline 78 & 60,3 & & 2,20 & $1, \mathrm{C}$ & 23,79 & 25 & 104,27 & 85 & 115,39 & 120,97 \\
\hline 79 & & & 2,20 & & 22,83 & & 100,07 & & 114,07 & 119,64 \\
\hline 80 & & & 2,20 & & 24,73 & & 108,40 & & 119,52 & 125,09 \\
\hline 81 & & & 2,2 & & 23,03 & & 100,94 & & 113,30 & 118,88 \\
\hline 82 & & & 2,2 & & 23,71 & & 103,92 & & 115,04 & 120,62 \\
\hline 83 & & & & & & & 108,79 & & 121,15 & 126,73 \\
\hline 84 & 57,3 & & & & 24,69 & & 108,22 & & 121,40 & 126,98 \\
\hline 85 & 56,2 & & 2,20 & & 25,79 & & 113,04 & & 126,22 & 131,80 \\
\hline 86 & 58,30 & 12,77 & 2,19 & & 24,18 & & 105,97 & 111,47 & 118,74 & 124,24 \\
\hline MÉDIA & 59,25 & 11,43 & 2,20 & 1,00 & 24,55 & & 107,61 & 113,19 & 119,04 & 124,61 \\
\hline DP & 1,158 & 1,182 & 0,002 & 0,001 & 0,838 & 0,838 & 3,672 & 3,675 & 3,401 & 3,403 \\
\hline
\end{tabular}


Tabela 3. Análises rápidas da composição dos lotes do misturador na preparação do corned beef do tratamento 4 .

\begin{tabular}{|c|c|c|c|c|c|c|c|c|c|c|}
\hline Lotes & 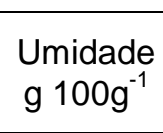 & $\begin{array}{l}\text { Lipídeos } \\
\text { g } 100 \mathrm{~g}^{-1}\end{array}$ & $\begin{array}{l}\text { Sal } \\
\%\end{array}$ & $\begin{array}{c}\text { Açúcar } \\
\%\end{array}$ & 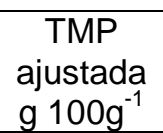 & $\begin{array}{c}\text { TMP } \\
\mathrm{g} 100 \mathrm{~g}^{-1}\end{array}$ & $\begin{array}{c}\text { LMC } \\
\text { ajustado } \\
\%\end{array}$ & $\begin{array}{c}\mathrm{LMC} \\
\%\end{array}$ & $\begin{array}{c}\text { TMC } \\
\text { ajustado } \\
\%\end{array}$ & $\begin{array}{c}\text { TMC } \\
\%\end{array}$ \\
\hline 1 & 56,08 & 12,36 & 2,20 & 1,00 & 26,79 & 28,06 & 117,43 & 123,00 & 129,79 & 135,36 \\
\hline 2 & 57,98 & 12,36 & 2,20 & 1,00 & 24,89 & 26,16 & 109,10 & 114,67 & 121,46 & 127,03 \\
\hline 3 & 58,61 & 11,12 & 2,20 & 1,00 & 25,50 & 26,77 & 111,77 & 117,35 & 122,89 & 128,47 \\
\hline 4 & 60,35 & 11,53 & 2,20 & 1,00 & 23,35 & 24,62 & 102,35 & 107,92 & 113,88 & 119,45 \\
\hline 5 & 59,04 & 13,18 & 2,20 & 1,00 & 23,01 & 24,28 & 100,86 & 106,43 & 114,04 & 119,61 \\
\hline 6 & 57,16 & 14,83 & 2,20 & 1,00 & 23,24 & 24,51 & 101,86 & 107,44 & 116,69 & 122,27 \\
\hline 7 & 57,00 & 14,42 & 2,20 & 1,00 & 23,81 & 25,08 & 104,36 & 109,94 & 118,78 & 124,36 \\
\hline 8 & 58,69 & 13,59 & 2,20 & 1,00 & 22,95 & 24,22 & 100,59 & 106,17 & 114,18 & 119,76 \\
\hline 9 & 57,77 & 12,77 & 2,20 & 1,00 & 24,69 & 25,96 & 108,22 & 113,80 & 120,99 & 126,57 \\
\hline 10 & 57,76 & 14,83 & 2,20 & 1,00 & 22,64 & 23,91 & 99,23 & 104,81 & 114,06 & 119,64 \\
\hline 11 & 58,33 & 14,00 & 2,20 & 1,00 & 22,90 & 24,17 & 100,37 & 105,95 & 114,37 & 119,95 \\
\hline 12 & 58,51 & 13,18 & 2,20 & 1,00 & 23,54 & 24,81 & 103,18 & 108,76 & 116,36 & 121,94 \\
\hline 13 & 59,47 & 12,77 & 2,20 & 1,00 & 22,99 & 24,26 & 100,77 & 106,35 & 113,54 & 119,12 \\
\hline 14 & 60,73 & 11,12 & 2,20 & 1,00 & 23,38 & 24,65 & 102,48 & 108,05 & 113,60 & 119,17 \\
\hline 15 & 58,61 & 12,36 & 2,20 & 1,00 & 24,26 & 25,53 & 106,34 & 111,91 & 118,70 & 124,27 \\
\hline 16 & 58,93 & 12,36 & 2,20 & 1,00 & 23,94 & 25,21 & 104,93 & 110,51 & 117,29 & 122,87 \\
\hline 17 & 58,79 & 13,18 & 2,20 & 1,00 & 23,26 & 24,53 & 101,95 & 107,53 & 115,13 & 120,71 \\
\hline 18 & 58,69 & 13,18 & 2,20 & 1,00 & 23,36 & 24,63 & 102,39 & 107,97 & 115,57 & 121,15 \\
\hline 19 & 57,31 & 14,00 & 2,20 & 1,00 & 23,92 & 25,19 & 104,84 & 110,42 & 118,84 & 124,42 \\
\hline 20 & 57,60 & 14,42 & 2,20 & 1,00 & 23,21 & 24,48 & 101,73 & 107,31 & 116,15 & 121,73 \\
\hline 21 & 57,67 & 12,77 & 2,20 & 1,00 & 24,79 & 26,06 & 108,66 & 114,24 & 121,43 & 127,01 \\
\hline 22 & 59,09 & 11,94 & 2,20 & 1,00 & 24,20 & 25,47 & 106,07 & 111,65 & 118,01 & 123,59 \\
\hline 23 & 58,90 & 11,53 & 2,20 & 1,00 & 24,80 & 26,07 & 108,70 & 114,28 & 120,23 & 125,81 \\
\hline 24 & 56,87 & 14,00 & 2,20 & 1,00 & 24,36 & 25,63 & 106,77 & 112,35 & 120,77 & 126,35 \\
\hline 25 & 57,17 & 13,59 & 2,20 & 1,00 & 24,47 & 25,74 & 107,26 & 112,83 & 120,85 & 126,42 \\
\hline 26 & 57,30 & 14,42 & 2,20 & 1,00 & 23,51 & 24,78 & 103,05 & 108,62 & 117,47 & 123,04 \\
\hline 27 & 58,60 & 14,42 & 2,20 & 1,00 & 22,21 & 23,48 & 97,35 & 102,93 & 111,77 & 117,35 \\
\hline 28 & 57,64 & 13,18 & 2,20 & 1,00 & 24,41 & 25,68 & 106,99 & 112,57 & 120,17 & 125,75 \\
\hline 29 & 58,60 & 14,42 & 2,20 & 1,00 & 22,21 & 23,48 & 97,35 & 102,93 & 111,77 & 117,35 \\
\hline 30 & 58,53 & 12,36 & 2,20 & 1,00 & 24,34 & 25,61 & 106,69 & 112,26 & 119,05 & 124,62 \\
\hline 31 & 57,85 & 12,36 & 2,18 & 0,99 & 25,04 & 26,29 & 109,78 & 115,24 & 122,14 & 127,60 \\
\hline 32 & 58,53 & & 2,20 & 1,00 & 25,17 & 26,44 & 110,32 & 115,90 & 121,85 & 127,43 \\
\hline 33 & 59,05 & 11,12 & 2,18 & 0,99 & 25,08 & 26,33 & 109,96 & 115,42 & 121,08 & 126,54 \\
\hline 34 & 58,88 & 10,30 & 2,20 & 1,00 & 26,05 & 27,32 & 114,18 & 119,76 & 124,48 & 130,06 \\
\hline 35 & 59,24 & & 2,20 & 1,0 & 25,28 & 26 & 110,81 & 11 & 121,52 & 127,09 \\
\hline 36 & 60,82 & & 2,20 & 1,0 & 24,11 & 25,38 & 105,68 & 111,25 & 115,98 & 121,55 \\
\hline 37 & 60, & 10 & 2,20 & 1,0 & 24,80 & 26 & 108,70 & 11 & 119,00 & 124,58 \\
\hline 38 & 6 & & 2,20 & 1,0 & 24,00 & 25,27 & 105,20 & & 115,08 & 120,65 \\
\hline 39 & & & 2,20 & 1,0 & 24,03 & & 105,33 & & 117,69 & 123,26 \\
\hline 40 & & & 2,20 & 1,0 & 24,74 & & 108,44 & & 120,38 & 125,96 \\
\hline 41 & & & 2,20 & 1,0 & 23,29 & & 102,08 & & 112,38 & 117,96 \\
\hline 42 & & & 2,20 & & 24,38 & & 106,86 & & 119,63 & 125,21 \\
\hline 43 & 55,90 & & 2,20 & & 24,50 & & 107,39 & & 122,22 & 127,79 \\
\hline 44 & 59,39 & & 2,20 & 1,00 & 23,48 & & 102,92 & & 115,28 & 120,85 \\
\hline 45 & 59,98 & 12,36 & 2,20 & 1,00 & 22,89 & 24,16 & 100,33 & 105,91 & 112,69 & 118,27 \\
\hline 46 & 56,63 & 14,00 & 2,20 & 1,00 & 24,60 & 25,87 & 107,83 & 113,40 & 121,83 & 127,40 \\
\hline 47 & 59,67 & 11,12 & 2,20 & 1,00 & 24,44 & 25,71 & 107,12 & 112,70 & 118,24 & 123,82 \\
\hline 48 & 61,74 & 10,30 & 2,20 & 1,00 & 23,19 & 24,46 & 101,64 & 107,22 & 111,94 & 117,52 \\
\hline
\end{tabular}


Tabela 3. Análises rápidas da composição dos lotes do misturador na preparação do corned beef do tratamento 4 (continuação).

\begin{tabular}{|c|c|c|c|c|c|c|c|c|c|c|}
\hline Lotes & 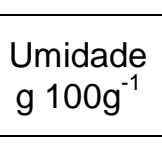 & 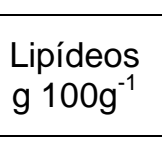 & $\begin{array}{l}\text { Sal } \\
\%\end{array}$ & $\begin{array}{c}\text { Açúcar } \\
\%\end{array}$ & 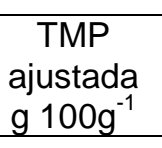 & $\begin{array}{c}\text { TMP } \\
\mathrm{g} 100 \mathrm{~g}^{-1}\end{array}$ & $\begin{array}{c}\text { LMC } \\
\text { ajustado } \\
\% \\
\end{array}$ & $\begin{array}{c}\mathrm{LMC} \\
\%\end{array}$ & $\begin{array}{c}\text { TMC } \\
\text { ajustado } \\
\% \\
\end{array}$ & $\begin{array}{l}\text { TMC } \\
\%\end{array}$ \\
\hline 49 & 60,90 & 10,30 & 2,20 & 1,00 & 24,03 & 25,30 & 105,33 & 110,90 & 115,63 & 121,20 \\
\hline 50 & 58,44 & 12,77 & 2,20 & 1,00 & 24,02 & 25,29 & 105,28 & 110,86 & 118,05 & 123,63 \\
\hline 51 & 58,71 & 12,77 & 2,20 & 1,00 & 23,75 & 25,02 & 104,10 & 109,68 & 116,87 & 122,45 \\
\hline 52 & 59,50 & 11,12 & 2,20 & 1,00 & 24,61 & 25,88 & 107,87 & 113,45 & 118,99 & 124,57 \\
\hline 53 & 59,00 & 11,12 & 2,20 & 1,00 & 25,11 & 26,38 & 110,06 & 115,64 & 121,18 & 126,76 \\
\hline 54 & 61,81 & 9,88 & 2,20 & 1,00 & 23,54 & 24,81 & 103,18 & 108,76 & 113,06 & 118,64 \\
\hline 55 & 60,95 & 11,12 & 2,20 & 1,00 & 23,16 & 24,43 & 101,51 & 107,09 & 112,63 & 118,21 \\
\hline 56 & 58,71 & 11,53 & 2,20 & 1,00 & 24,99 & 26,26 & 109,54 & 115,11 & 121,07 & 126,64 \\
\hline 57 & 56,72 & 11,53 & 2,20 & 1,00 & 26,98 & 28,25 & 118,26 & 123,84 & 129,79 & 135,37 \\
\hline 58 & 60,98 & 10,30 & 2,20 & 1,00 & 23,95 & 25,22 & 104,98 & 110,55 & 115,28 & 120,85 \\
\hline 59 & 59,48 & 12,3 & 2,20 & 1,00 & 23,39 & 24,66 & 102,52 & 108,10 & 114,88 & 120,46 \\
\hline 60 & 57,7 & 14 & 2,20 & 1,0 & 23,52 & 24,79 & 103,09 & 108,67 & 117,09 & 122,67 \\
\hline 61 & 58,38 & & 2,20 & 1,0 & 23,67 & 24,94 & 103,75 & 109 & 116,93 & 122,51 \\
\hline 62 & 58,62 & 13 & 2,20 & 1,0 & 23,02 & 24,29 & 100,90 & 106,48 & 114,49 & 120,07 \\
\hline 63 & 57,98 & 11,53 & 2,20 & 1,00 & 25,72 & 26,99 & 112,74 & 118,31 & 124,27 & 129,84 \\
\hline 64 & 59,71 & 10,71 & 2,20 & 1,00 & 24,81 & 26,08 & 108,75 & 114,32 & 119,46 & 125,03 \\
\hline 65 & 60,53 & 10,30 & 2,20 & 1,00 & 24,40 & 25,67 & 106,95 & 112,53 & 117,25 & 122,83 \\
\hline 66 & 59,06 & 11,94 & 2,20 & 1,00 & 24,23 & 25,50 & 106,20 & 111,78 & 118,14 & 123,72 \\
\hline 67 & 60,99 & 10,30 & 2,20 & 1,00 & 23,94 & 25,21 & 104,93 & 110,51 & 115,23 & 120,81 \\
\hline 68 & 60,84 & 10,30 & 2,20 & 1,00 & 24,09 & 25,36 & 105,59 & 111,17 & 115,89 & 121,47 \\
\hline 69 & 60,67 & 10,71 & 2,20 & 1,00 & 23,85 & 25,12 & 104,54 & 110,12 & 115,25 & 120,83 \\
\hline 70 & 58,93 & 11,12 & 2,20 & 1,00 & 25,18 & 26,45 & 110,37 & 115,95 & 121,49 & 127,07 \\
\hline 71 & 59,87 & & 2,20 & 1,0 & 24,65 & 25,92 & 108,04 & 113,62 & 118,75 & 124,33 \\
\hline 72 & 60,3 & & 2,20 & 1,0 & 22,96 & 24,23 & 100,64 & 106,21 & 112,58 & 118,15 \\
\hline 73 & 59,1 & & 2,20 & 1,0 & 25,00 & 26 , & 109,58 & 115,16 & 120,70 & 126,28 \\
\hline 74 & 60,84 & & 2,20 & 1,00 & 24,09 & & 105,59 & 111,17 & 115,89 & 121,47 \\
\hline MÉDIA & & & 2,20 & 1,00 & 24,11 & 25,39 & 105,71 & 111,28 & 117,87 & 123,44 \\
\hline DP & 1,372 & 1,424 & 0,003 & 0,001 & 0,940 & 0,939 & 4,121 & 4,118 & 3,809 & 3,806 \\
\hline
\end{tabular}


Tabela 4. Análises rápidas da composição dos lotes do misturador na preparação do corned beef do tratamento 5 .

\begin{tabular}{|c|c|c|c|c|c|c|c|c|c|c|}
\hline Lotes & 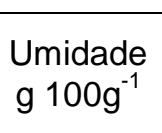 & 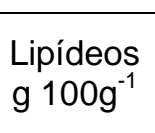 & $\begin{array}{l}\text { Sal } \\
\%\end{array}$ & $\begin{array}{c}\text { Açúcar } \\
\%\end{array}$ & $\begin{array}{c}\text { TMP } \\
\text { ajustada } \\
\mathrm{g} 100 \mathrm{~g}^{-1}\end{array}$ & $\begin{array}{c}\text { TMP } \\
\mathrm{g} 100 \mathrm{~g}^{-1}\end{array}$ & $\begin{array}{c}\text { LMC } \\
\text { ajustado } \\
\%\end{array}$ & $\begin{array}{c}\mathrm{LMC} \\
\%\end{array}$ & $\begin{array}{c}\text { TMC } \\
\text { ajustado } \\
\%\end{array}$ & $\begin{array}{l}\text { TMC } \\
\%\end{array}$ \\
\hline 1 & 57,96 & 12,77 & 2,20 & 1,00 & 24,50 & 25,77 & 107,39 & 112,96 & 120,16 & 125,73 \\
\hline 2 & 59,43 & 11,12 & 2,20 & 1,00 & 24,68 & 25,95 & 108,18 & 113,75 & 119,30 & 124,87 \\
\hline 3 & 59,50 & 10,71 & 2,20 & 1,00 & 25,02 & 26,29 & 109,67 & 115,24 & 120,38 & 125,95 \\
\hline 4 & 59,32 & 10,30 & 2,20 & 1,00 & 25,61 & 26,88 & 112,25 & 117,83 & 122,55 & 128,13 \\
\hline 5 & 57,08 & 12,36 & 2,20 & 1,00 & 25,79 & 27,06 & 113,04 & 118,62 & 125,40 & 130,98 \\
\hline 6 & 58,16 & 11,94 & 2,20 & 1,00 & 25,13 & 26,40 & 110,15 & 115,73 & 122,09 & 127,67 \\
\hline 7 & 58,85 & 11,94 & 2,20 & 1,00 & 24,44 & 25,71 & 107,12 & 112,70 & 119,06 & 124,64 \\
\hline 8 & 57,21 & 14,00 & 2,20 & 1,00 & 24,02 & 25,29 & 105,28 & 110,86 & 119,28 & 124,86 \\
\hline 9 & 60,86 & & 2,20 & 1,00 & 24,07 & 25,34 & 105,50 & 111,08 & 115,80 & 121,38 \\
\hline 10 & 60,03 & 53 & 2,20 & 1,00 & 23,67 & 24,94 & 103,75 & 109,33 & 115,28 & 120,86 \\
\hline 11 & 58,38 & 14,00 & 2,20 & 1,00 & 22,85 & 24,12 & 100,15 & 105,73 & 114,15 & 119,73 \\
\hline 12 & 58,57 & 11,94 & 2,20 & 1,00 & 24,72 & 25,99 & 108,35 & 113,93 & 120,29 & 125,87 \\
\hline 13 & 58,60 & & 2,20 & 1,00 & 23,45 & 24,72 & 102,78 & 108,36 & 115,96 & 121,54 \\
\hline 14 & 58,84 & & 2,20 & 1,00 & 23,21 & 24,48 & 101,73 & 107,31 & 114,91 & 120,49 \\
\hline 15 & 59,49 & 12 & 2,20 & 1,00 & 24,62 & 25,89 & 107,91 & 113,49 & 119,03 & 124,61 \\
\hline 16 & 59,19 & 11,00 & 2,20 & 1,00 & 25,04 & 26,31 & 109,75 & 115,33 & 120,75 & 126,33 \\
\hline 17 & 59,27 & 12,77 & 2,20 & 1,00 & 23,19 & 24,46 & 101,64 & 107,22 & 114,41 & 119,99 \\
\hline 18 & 60,76 & 10,30 & 2,20 & 1,00 & 24,17 & 25,44 & 105,94 & 111,52 & 116,24 & 121,82 \\
\hline 19 & 56,62 & 14,83 & 2,20 & 1,00 & 23,78 & 25,05 & 104,23 & 109,81 & 119,06 & 124,64 \\
\hline 20 & 60,69 & 10,30 & 2,20 & 1,00 & 24,24 & 25,51 & 106,25 & 111,82 & 116,55 & 122,12 \\
\hline 21 & 56,96 & 12,36 & 2,20 & 1,00 & 25,91 & 27,18 & 113,57 & 119,15 & 125,93 & 131,51 \\
\hline 22 & 59,89 & 10,71 & 2,20 & 1,00 & 24,63 & 25,90 & 107,96 & 113,53 & 118,67 & 124,24 \\
\hline 23 & 60,60 & 10,71 & 2,20 & 1,00 & 23,92 & 25,19 & 104,84 & 110,42 & 115,55 & 121,13 \\
\hline 24 & 58,91 & 12,36 & 2,20 & 1,00 & 23,96 & 25,23 & 105,02 & 110,60 & 117,38 & 122,96 \\
\hline 25 & 59,74 & 11,12 & 2,20 & 1,00 & 24,37 & 25,64 & 106,82 & 112,39 & 117,94 & 123,51 \\
\hline 26 & 58,80 & 13,18 & 2,20 & 1,00 & 23,25 & 24,52 & 101,91 & 107,48 & 115,09 & 120,66 \\
\hline 27 & 58,88 & 13,18 & 2,20 & 1,00 & 23,17 & 24,44 & 101,56 & 107,13 & 114,74 & 120,31 \\
\hline 28 & 57,95 & 12,36 & 2,20 & 1,00 & 24,92 & 26,19 & 109,23 & 114,81 & 121,59 & 127,17 \\
\hline 29 & 58,70 & 13,18 & 2,20 & 1,00 & 23,35 & 24,62 & 102,35 & 107,92 & 115,53 & 121,10 \\
\hline 30 & 59,43 & 12,36 & 2,20 & 1,00 & 23,44 & 24,71 & 102,74 & 108,32 & 115,10 & 120,68 \\
\hline 31 & 57,27 & 11,53 & 2,20 & 1,00 & 26,43 & 27,70 & 115,85 & 121,42 & 127,38 & 132,95 \\
\hline 32 & 59,89 & 11,12 & 2,20 & 1,00 & 24,22 & 25,49 & 106,16 & 111,74 & 117,28 & 122,86 \\
\hline 33 & 61,10 & 10,71 & 2,20 & 1,00 & 23,42 & 24,69 & 102,65 & 108,23 & 113,36 & 118,94 \\
\hline 34 & 58,21 & 13,59 & 2,20 & 1,00 & 23,43 & 24,70 & 102,70 & 108,27 & 116,29 & 121,86 \\
\hline 35 & 61,14 & 10,30 & 2,20 & 1,00 & 23,79 & 25,06 & 104,27 & 109,85 & 114,57 & 120,15 \\
\hline 36 & 61,50 & 10,30 & 2,20 & 1,00 & 23,43 & 24,70 & 102,70 & 108,27 & 113,00 & 118,57 \\
\hline 37 & 59,70 & 14,00 & 2,20 & 1,00 & 21,53 & 22,80 & 94,37 & 99,95 & 108,37 & 113,95 \\
\hline 38 & 56,29 & 14,83 & 2,20 & 1,00 & 24,11 & 25,38 & 105,68 & 111,25 & 120,51 & 126,08 \\
\hline 39 & 58,44 & 14,00 & 2,20 & 1,00 & 22,79 & 24,06 & 99,89 & 105,47 & 113,89 & 119,47 \\
\hline 40 & 58,62 & & 2,20 & 1,00 & 23,43 & 24,70 & 102,70 & 108,27 & 115,88 & 121,45 \\
\hline 41 & 57,3 & & 2,20 & 1,00 & 24,25 & 25,52 & 106,29 & 111,87 & 119,88 & 125,46 \\
\hline 42 & 56,8 & 14,83 & 2,20 & 1,00 & 23,55 & 24,82 & 103,22 & 108,80 & 118,05 & 123,63 \\
\hline 43 & 56,56 & 14,42 & 2,20 & 1,00 & 24,25 & 25,52 & 106,29 & 111,87 & 120,71 & 126,29 \\
\hline 44 & 57,73 & 14,8 & 2,20 & 1,00 & 22,67 & 23,94 & 99,37 & 104,94 & 114,20 & 119,77 \\
\hline 45 & 59,50 & 13,59 & 2,20 & 1,00 & 22,14 & 23,41 & 97,04 & 102,62 & 110,63 & 116,21 \\
\hline
\end{tabular}


Tabela 4. Análises rápidas da composição dos lotes do misturador na preparação do corned beef do tratamento 5 (continuação).

\begin{tabular}{|c|c|c|c|c|c|c|c|c|c|c|}
\hline Lotes & 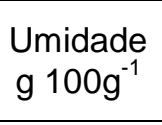 & $\begin{array}{l}\text { Lipídeos } \\
\text { g } 100 \mathrm{~g}^{-1}\end{array}$ & $\begin{array}{l}\text { Sal } \\
\%\end{array}$ & $\begin{array}{c}\text { Açúcar } \\
\%\end{array}$ & $\begin{array}{c}\text { TMP } \\
\text { ajustada } \\
\text { g } 100 \mathrm{~g}^{-1}\end{array}$ & $\begin{array}{c}\text { TMP } \\
{\mathrm{g} 100 \mathrm{~g}^{-1}}\end{array}$ & $\begin{array}{c}\text { LMC } \\
\text { ajustado } \\
\%\end{array}$ & $\begin{array}{c}\mathrm{LMC} \\
\%\end{array}$ & $\begin{array}{c}\text { TMC } \\
\text { ajustado } \\
\% \\
\end{array}$ & $\begin{array}{c}\text { TMC } \\
\%\end{array}$ \\
\hline 46 & 60,11 & 11,12 & 2,20 & 1,00 & 24,00 & 25,27 & 105,20 & 110,77 & 116,32 & 121,89 \\
\hline 47 & 57,80 & 14,42 & 2,20 & 1,00 & 23,01 & 24,28 & 100,86 & 106,43 & 115,28 & 120,85 \\
\hline 48 & 56,29 & 14,00 & 2,20 & 1,00 & 24,94 & 26,21 & 109,32 & 114,89 & 123,32 & 128,89 \\
\hline 49 & 56,35 & 13,18 & 2,20 & 1,00 & 25,70 & 26,97 & 112,65 & 118,22 & 125,83 & 131,40 \\
\hline 50 & 57,69 & 11,53 & 2,20 & 1,00 & 26,01 & 27,28 & 114,01 & 119,58 & 125,54 & 131,11 \\
\hline 51 & 57,70 & 11,12 & 2,20 & 1,00 & 26,41 & 27,68 & 115,76 & 121,34 & 126,88 & 132,46 \\
\hline 52 & 59,79 & 11,12 & 2,20 & 1,00 & 24,32 & 25,59 & 106,60 & 112,18 & 117,72 & 123,30 \\
\hline 53 & 57,28 & 12,77 & 2,20 & 1,00 & 25,18 & 26,45 & 110,37 & 115,95 & 123,14 & 128,72 \\
\hline 54 & 56,79 & 14,00 & 2,20 & 1,00 & 24,44 & 25,71 & 107,12 & 112,70 & 121,12 & 126,70 \\
\hline 55 & 60,83 & 10,30 & 2,20 & 1,00 & 24,10 & 25,37 & 105,63 & 111,21 & 115,93 & 121,51 \\
\hline 56 & 58,86 & 12,36 & 2,20 & 1,00 & 24,01 & 25,28 & 105,24 & 110,82 & 117,60 & 123,18 \\
\hline 57 & 58,17 & 14,00 & 2,20 & 1,00 & 23,06 & 24,33 & 101,07 & 106,65 & 115,07 & 120,65 \\
\hline 58 & 59,02 & 12,36 & 2,20 & 1,00 & 23,85 & 25,12 & 104,54 & 110,12 & 116,90 & 122,48 \\
\hline 59 & 56,73 & 12,77 & 2,20 & 1,00 & 25,73 & 27,00 & 112,78 & 118,36 & 125,55 & 131,13 \\
\hline 60 & 58,10 & 13,18 & 2,20 & 1,00 & 23,95 & 25,22 & 104,98 & 110,55 & 118,16 & 123,73 \\
\hline 61 & 58,42 & 11,53 & 2,20 & 1,00 & 25,28 & 26,55 & 110,81 & 116,38 & 122,34 & 127,91 \\
\hline 62 & 58,85 & 14,00 & 2,20 & 1,00 & 22,38 & 23,65 & 98,09 & 103,67 & 112,09 & 117,67 \\
\hline 63 & 58,53 & 12,77 & 2,20 & 1,00 & 23,93 & 25,20 & 104,89 & 110,47 & 117,66 & 123,24 \\
\hline 64 & 57,61 & 14,42 & 2,20 & 1,00 & 23,20 & 24,47 & 101,69 & 107,27 & 116,11 & 121,69 \\
\hline 65 & 59,52 & 12,36 & 2,20 & 1,00 & 23,35 & 24,62 & 102,35 & 107,92 & 114,71 & 120,28 \\
\hline 66 & 57,76 & 14,83 & 2,20 & 1,0 & 22,64 & 23,91 & 99,23 & 104,81 & 114,06 & 119,64 \\
\hline 67 & 57,73 & & 2,20 & 1,0 & 24,32 & 25,59 & 106,60 & 112,18 & 119,78 & 125,36 \\
\hline 68 & 56,30 & & 2,20 & 1,0 & 26,99 & 28,26 & 118,30 & 123,88 & 130,24 & 135,82 \\
\hline 69 & 60,19 & & 2,20 & 1,00 & 23,92 & 25,19 & 104,84 & 110,42 & 115,96 & 121,54 \\
\hline MÉDIA & 58,63 & 12,47 & 2,20 & 1,00 & 24,13 & 25,40 & 105,79 & 111,36 & 118,25 & 123,83 \\
\hline DP & 1,345 & 1,402 & 0,000 & 0,000 & 1,063 & 1,063 & 4,659 & 4,659 & 4,246 & 4,246 \\
\hline
\end{tabular}


Tabela 5. Análises rápidas da composição dos lotes do misturador na preparação do corned beef do tratamento 6 .

\begin{tabular}{|c|c|c|c|c|c|c|c|c|c|c|}
\hline Lotes & 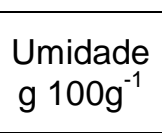 & $\begin{array}{l}\text { Lipídeos } \\
\text { g } 100 \mathrm{~g}^{-1}\end{array}$ & $\begin{array}{l}\text { Sal } \\
\%\end{array}$ & $\begin{array}{c}\text { Açúcar } \\
\%\end{array}$ & 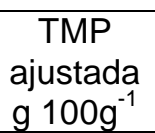 & 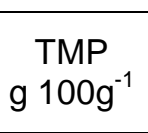 & $\begin{array}{c}\text { LMC } \\
\text { ajustado } \\
\%\end{array}$ & $\begin{array}{l}\text { LMC } \\
\%\end{array}$ & $\begin{array}{c}\text { TMC } \\
\text { ajustado } \\
\%\end{array}$ & $\begin{array}{l}\text { TMC } \\
\%\end{array}$ \\
\hline 1 & 56,17 & 15,24 & 2,20 & 1,00 & 23,82 & 25,09 & 104,41 & 109,98 & 119,65 & 125,22 \\
\hline 2 & 57,35 & 13,18 & 2,20 & 1,00 & 24,70 & 25,97 & 108,26 & 113,84 & 121,44 & 127,02 \\
\hline 3 & 58,16 & 11,94 & 2,20 & 1,00 & 25,13 & 26,40 & 110,15 & 115,73 & 122,09 & 127,67 \\
\hline 4 & 58,34 & 12,36 & 2,20 & 1,00 & 24,53 & 25,80 & 107,52 & 113,10 & 119,88 & 125,46 \\
\hline 5 & 56,50 & 14,42 & 2,20 & 1,00 & 24,31 & 25,58 & 106,55 & 112,13 & 120,97 & 126,55 \\
\hline 6 & 56,73 & 14,00 & 2,20 & 1,00 & 24,50 & 25,77 & 107,39 & 112,96 & 121,39 & 126,96 \\
\hline 7 & 55,52 & 15,24 & 2,20 & 1,00 & 24,47 & 25,74 & 107,26 & 112,83 & 122,50 & 128,07 \\
\hline 8 & 54,82 & 15,24 & 2,20 & 1,00 & 25,17 & 26,44 & 110,32 & 115,90 & 125,56 & 131,14 \\
\hline 9 & 58,53 & 11,12 & 2,20 & 1,00 & 25,58 & 26,85 & 112,12 & 117,70 & 123,24 & 128,82 \\
\hline 10 & 59,83 & 10,30 & 2,20 & 1,00 & 25,10 & 26,37 & 110,02 & 115,59 & 120,32 & 125,89 \\
\hline 11 & 59,81 & 10,30 & 2,20 & 1,00 & 25,12 & 26,39 & 110,11 & 115,68 & 120,41 & 125,98 \\
\hline 12 & 60,00 & 10,30 & 2,20 & 1,00 & 24,93 & 26,20 & 109,27 & 114,85 & 119,57 & 125,15 \\
\hline 13 & 58,42 & 11,12 & 2,20 & 1,00 & 25,69 & 26,96 & 112,60 & 118,18 & 123,72 & 129,30 \\
\hline 14 & 60,14 & 10,30 & 2,20 & 1,00 & 24,79 & 26,06 & 108,66 & 114,24 & 118,96 & 124,54 \\
\hline 15 & 59,36 & 12,36 & 2,20 & 1,00 & 23,51 & 24,78 & 103,05 & 108,62 & 115,41 & 120,98 \\
\hline 16 & 59,09 & 11,53 & 2,20 & 1,00 & 24,61 & 25,88 & 107,87 & 113,45 & 119,40 & 124,98 \\
\hline 17 & 60,41 & 10,71 & 2,20 & 1,00 & 24,11 & 25,38 & 105,68 & 111,25 & 116,39 & 121,96 \\
\hline 18 & 57,77 & 12,77 & 2,20 & 1,00 & 24,69 & 25,96 & 108,22 & 113,80 & 120,99 & 126,57 \\
\hline 19 & 58,02 & 10,30 & 2,20 & 1,00 & 26,91 & 28,18 & 117,95 & 123,53 & 128,25 & 133,83 \\
\hline 20 & 59,09 & 11,53 & 2,20 & 1,00 & 24,61 & 25,88 & 107,87 & 113,45 & 119,40 & 124,98 \\
\hline 21 & 58,57 & 10,30 & 2,20 & 1,00 & 26,36 & 27,63 & 115,54 & 121,12 & 125,84 & 131,42 \\
\hline 22 & 59,16 & 12,36 & 2,20 & 1,00 & 23,71 & 24,98 & 103,92 & 109,50 & 116,28 & 121,86 \\
\hline 23 & 60,59 & 11,12 & 2,20 & 1,00 & 23,52 & 24,79 & 103,09 & 108,67 & 114,21 & 119,79 \\
\hline 24 & 60,32 & 11,53 & 2,20 & 1,00 & 23,38 & 24,65 & 102,48 & 108,05 & 114,01 & 119,58 \\
\hline 25 & 58,71 & 11,94 & 2,20 & 1,00 & 24,58 & 25,85 & 107,74 & 113,32 & 119,68 & 125,26 \\
\hline 26 & 60,76 & 11,12 & 2,20 & 1,00 & 23,35 & 24,62 & 102,35 & 107,92 & 113,47 & 119,04 \\
\hline 27 & 60,83 & 11,53 & 2,20 & 1,00 & 22,87 & 24,14 & 100,24 & 105,82 & 111,77 & 117,35 \\
\hline 28 & 58,57 & 12,36 & 2,20 & 1,00 & 24,30 & 25,57 & 106,51 & 112,09 & 118,87 & 124,45 \\
\hline 29 & 60,96 & 10,71 & 2,20 & 1,00 & 23,56 & 24,83 & 103,27 & 108,84 & 113,98 & 119,55 \\
\hline 30 & 61,08 & 10,71 & 2,20 & 1,00 & 23,44 & 24,71 & 102,74 & 108,32 & 113,45 & 119,03 \\
\hline 31 & 59,05 & 12,36 & 2,20 & 1,00 & 23,82 & 25,09 & 104,41 & 109,98 & 116,77 & 122,34 \\
\hline 32 & 59,55 & 12,36 & 2,20 & 1,00 & 23,32 & 24,59 & 102,21 & 107,79 & 114,57 & 120,15 \\
\hline 33 & 59,46 & 11,94 & 2,20 & 1,00 & 23,83 & 25,10 & 104,45 & 110,03 & 116,39 & 121,97 \\
\hline 34 & 57,53 & 10,71 & 2,20 & 1,00 & 26,99 & 28,26 & 118,30 & 123,88 & 129,01 & 134,59 \\
\hline 35 & 59,72 & 10,30 & 2,20 & 1,00 & 25,21 & 26,48 & 110,50 & 116,08 & 120,80 & 126,38 \\
\hline 36 & 60,10 & 11,12 & 2,20 & 1,00 & 24,01 & 25,28 & 105,24 & 110,82 & 116,36 & 121,94 \\
\hline 37 & 59,45 & 11,94 & 2,20 & 1,00 & 23,84 & 25,11 & 104,49 & 110,07 & 116,43 & 122,01 \\
\hline 38 & 61,39 & 10,30 & 2,20 & 1,00 & 23,54 & 24,81 & 103,18 & 108,76 & 113,48 & 119,06 \\
\hline 39 & 57,69 & 14,42 & 2,20 & 1,00 & 23,12 & 24,39 & 101,34 & 106,92 & 115,76 & 121,34 \\
\hline 40 & 60,31 & 11,53 & 2,20 & 1,00 & 23,39 & 24,66 & 102,52 & 108,10 & 114,05 & 119,63 \\
\hline 41 & 59,36 & 11,12 & 2,20 & 1,00 & 24,75 & 26,02 & 108,48 & 114,06 & 119,60 & 125,18 \\
\hline 42 & 60,53 & 10,30 & 2,20 & 1,00 & 24,40 & 25,67 & 106,95 & 112,53 & 117,25 & 122,83 \\
\hline 43 & 60,55 & 11,53 & 2,20 & 1,00 & 23,15 & 24,42 & 101,47 & 107,05 & 113,00 & 118,58 \\
\hline 44 & 61,77 & 10,30 & 2,20 & 1,00 & 23,16 & 24,43 & 101,51 & 107,09 & 111,81 & 117,39 \\
\hline 45 & 60,05 & 10,30 & 2,20 & 1,00 & 24,88 & 26,15 & 109,05 & 114,63 & 119,35 & 124,93 \\
\hline 46 & 58,12 & 11,94 & 2,20 & 1,00 & 25,17 & 26,44 & 110,32 & 115,90 & 122,26 & 127,84 \\
\hline 47 & 60,50 & 10,30 & 2,20 & 1,00 & 24,43 & 25,70 & 107,08 & 112,66 & 117,38 & 122,96 \\
\hline 48 & 59,77 & 10,71 & 2,20 & 1,00 & 24,75 & 26,02 & 108,48 & 114,06 & 119,19 & 124,77 \\
\hline
\end{tabular}


Tabela 5. Análises rápidas da composição dos lotes do misturador na preparação do corned beef do tratamento 6 (continuação).

\begin{tabular}{|c|c|c|c|c|c|c|c|c|c|c|}
\hline Lotes & 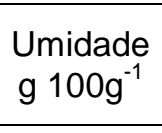 & $\begin{array}{l}\text { Lipídeos } \\
\mathrm{g} 100 \mathrm{~g}^{-1}\end{array}$ & $\begin{array}{l}\text { Sal } \\
\%\end{array}$ & $\begin{array}{c}\text { Açúcar } \\
\%\end{array}$ & 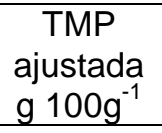 & $\begin{array}{c}\text { TMP } \\
\mathrm{g} 100 \mathrm{~g}^{-1}\end{array}$ & $\begin{array}{c}\text { LMC } \\
\text { ajustado } \\
\% \\
\end{array}$ & $\begin{array}{c}\mathrm{LMC} \\
\%\end{array}$ & $\begin{array}{c}\text { TMC } \\
\text { ajustado } \\
\% \\
\end{array}$ & $\underset{\%}{\mathrm{TMC}}$ \\
\hline 49 & 61,79 & 12,36 & 2,20 & 1,00 & 21,08 & 22,35 & 92,40 & 97,97 & 104,76 & 110,33 \\
\hline 50 & 60,79 & 14,00 & 2,20 & 1,00 & 20,44 & 21,71 & 89,59 & 95,17 & 103,59 & 109,17 \\
\hline 51 & 60,56 & 14,00 & 2,20 & 1,00 & 20,67 & 21,94 & 90,60 & 96,18 & 104,60 & 110,18 \\
\hline 52 & 62,13 & 11,12 & 2,20 & 1,00 & 21,98 & 23,25 & 96,34 & 101,92 & 107,46 & 113,04 \\
\hline 53 & 61,29 & 12,77 & 2,20 & 1,00 & 21,17 & 22,44 & 92,79 & 98,37 & 105,56 & 111,14 \\
\hline 54 & 62,80 & 11,53 & 2,20 & 1,00 & 20,90 & 22,17 & 91,61 & 97,18 & 103,14 & 108,71 \\
\hline MÉDIA & 59,41 & 11,80 & 2,20 & 1,00 & 24,02 & 25,30 & 105,31 & 110,88 & 117,11 & 122,68 \\
\hline DP & 1,66 & 1,42 & 0,00 & 0,00 & 1,40 & 1,40 & 6,12 & 6,12 & 5,85 & 5,85 \\
\hline
\end{tabular}


Anexo 2 - Figura 1. Carta gráfica do processamento térmico do tratamento 1.

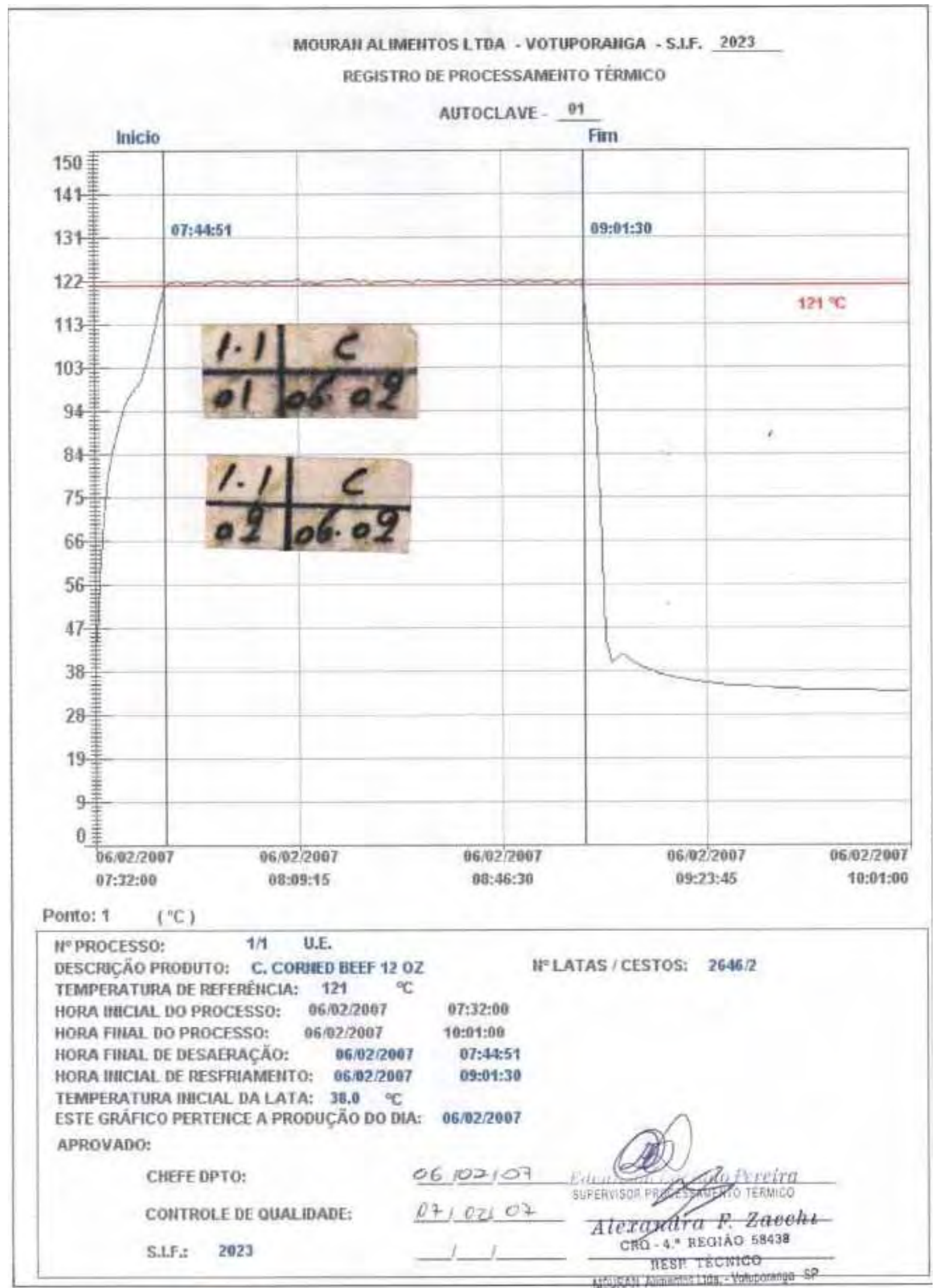


Anexo 2 - Figura 2. Carta gráfica do processamento térmico do tratamento 2.

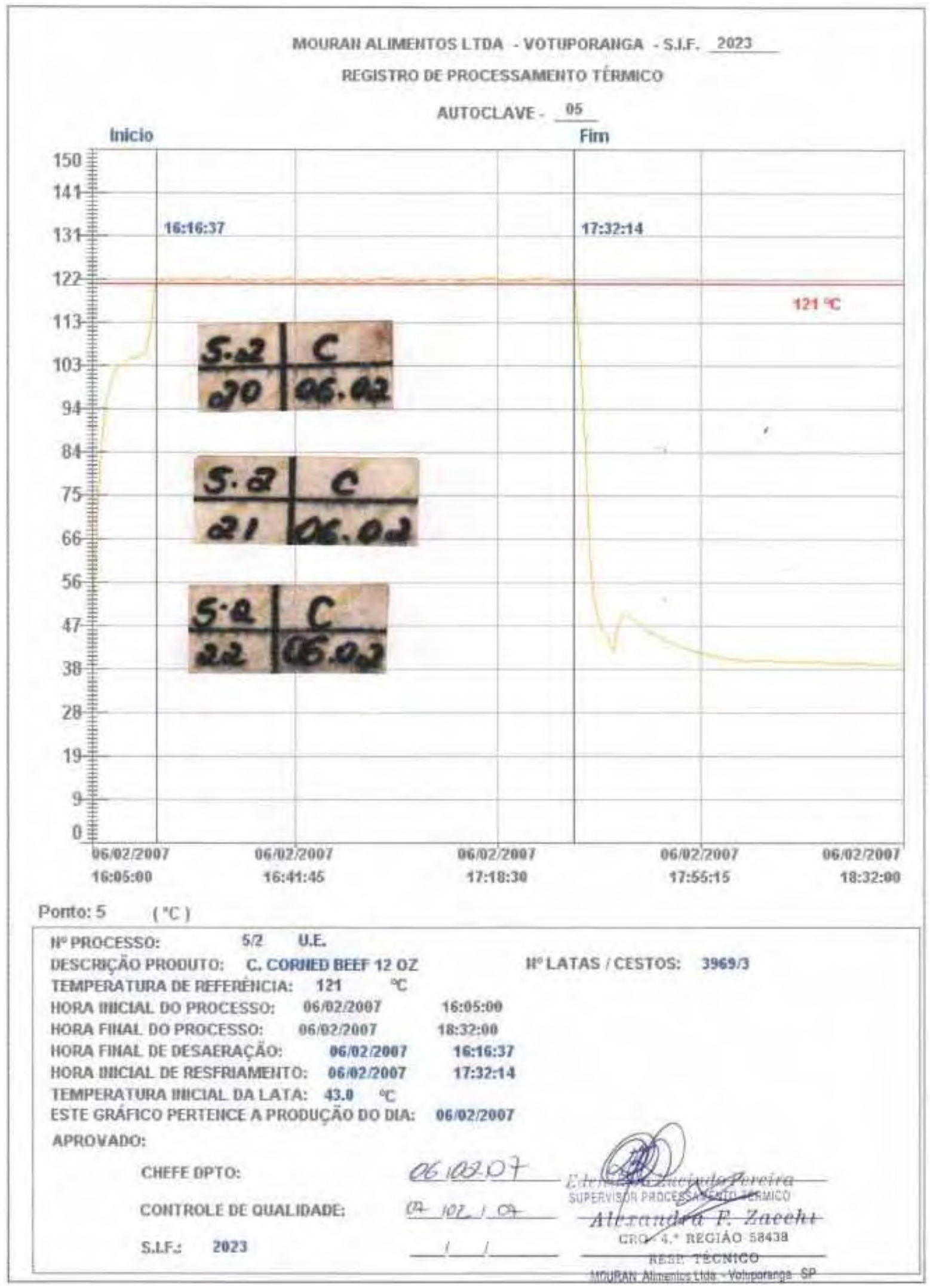


Anexo 2 - Figura 3. Carta gráfica do processamento térmico do tratamento 3.

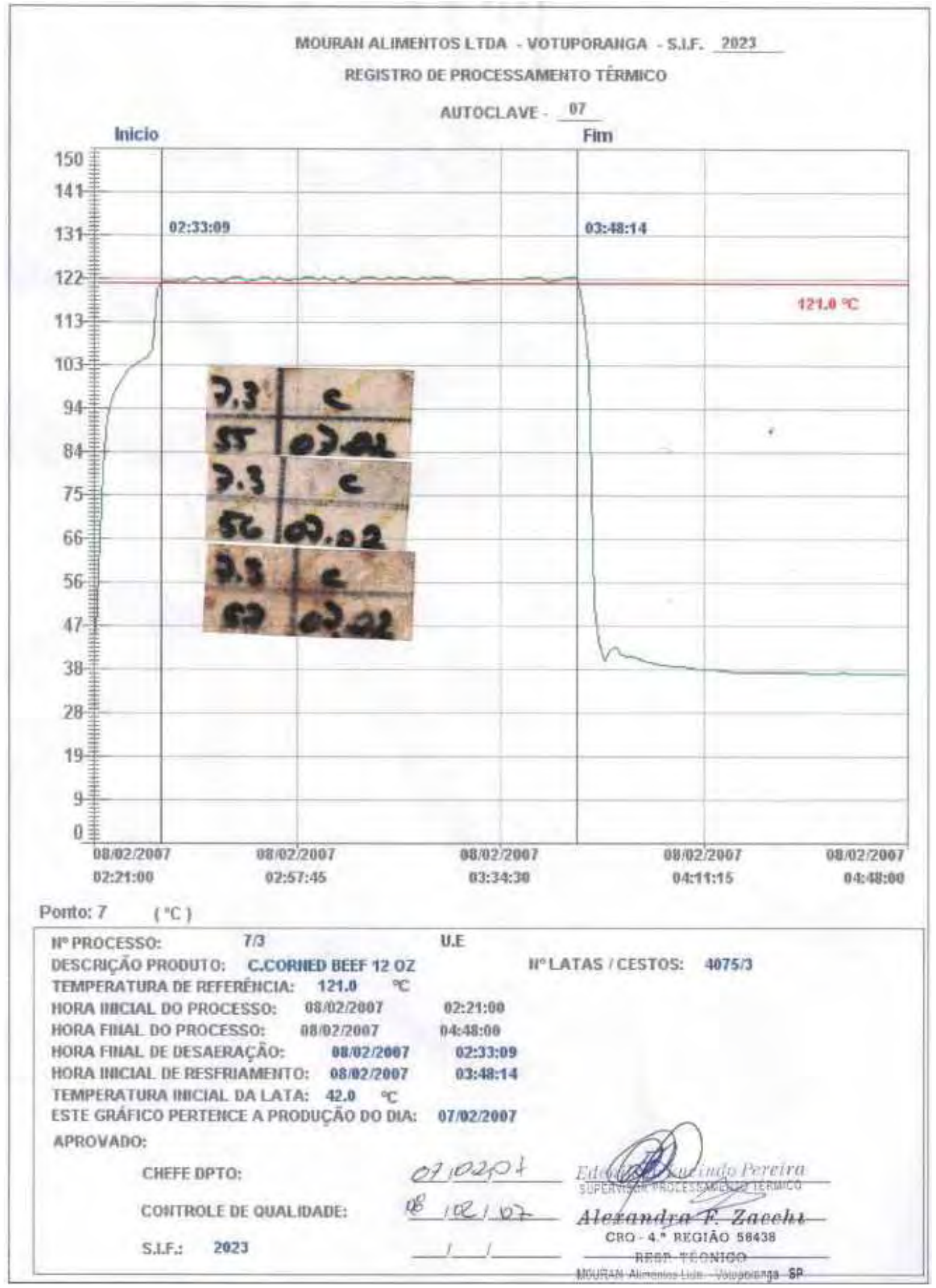


Anexo 2 - Figura 4. Carta gráfica do processamento térmico do tratamento 4.

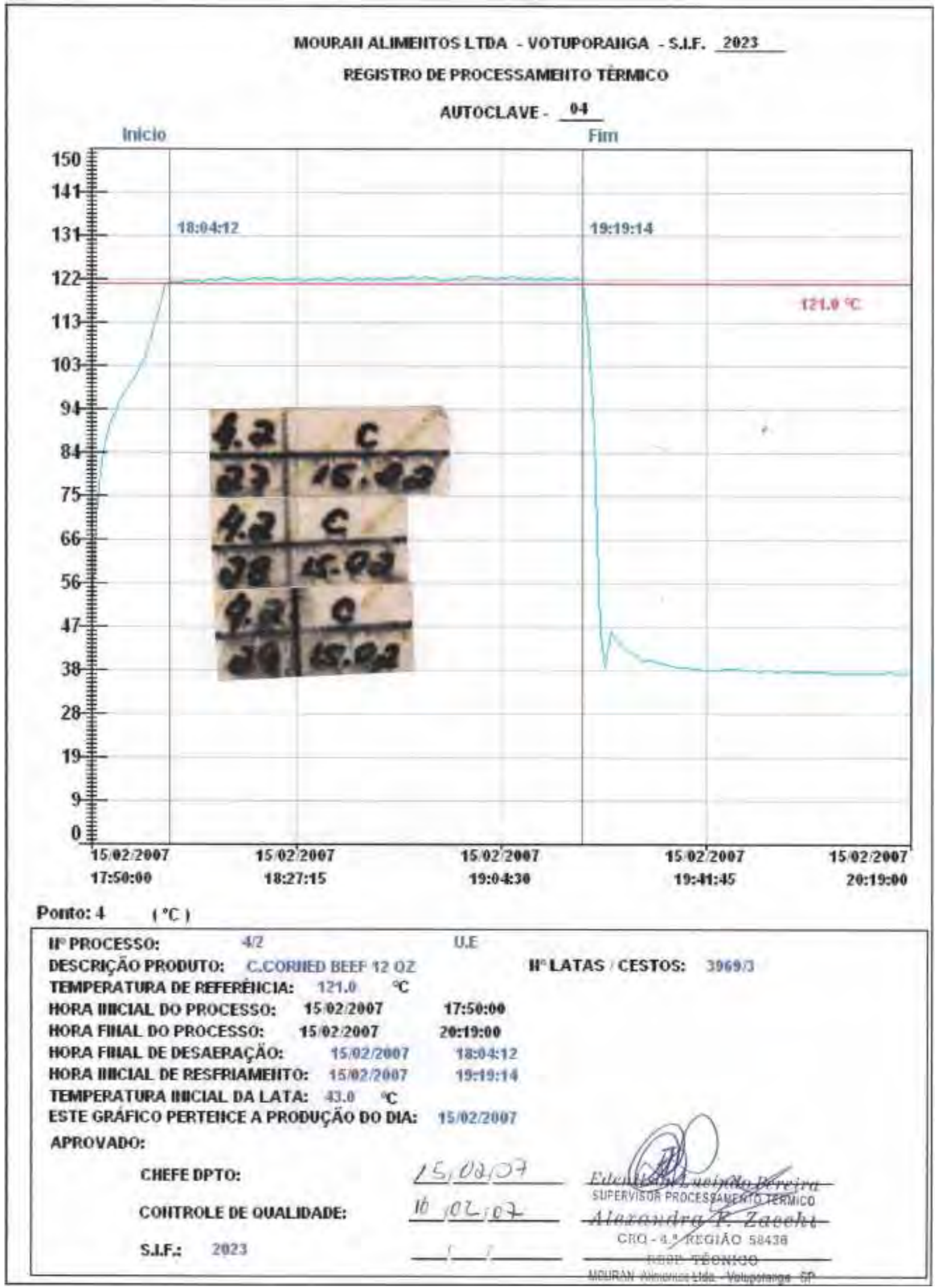


Anexo 2- Figura 5. Carta gráfica do processamento térmico do tratamento 5.

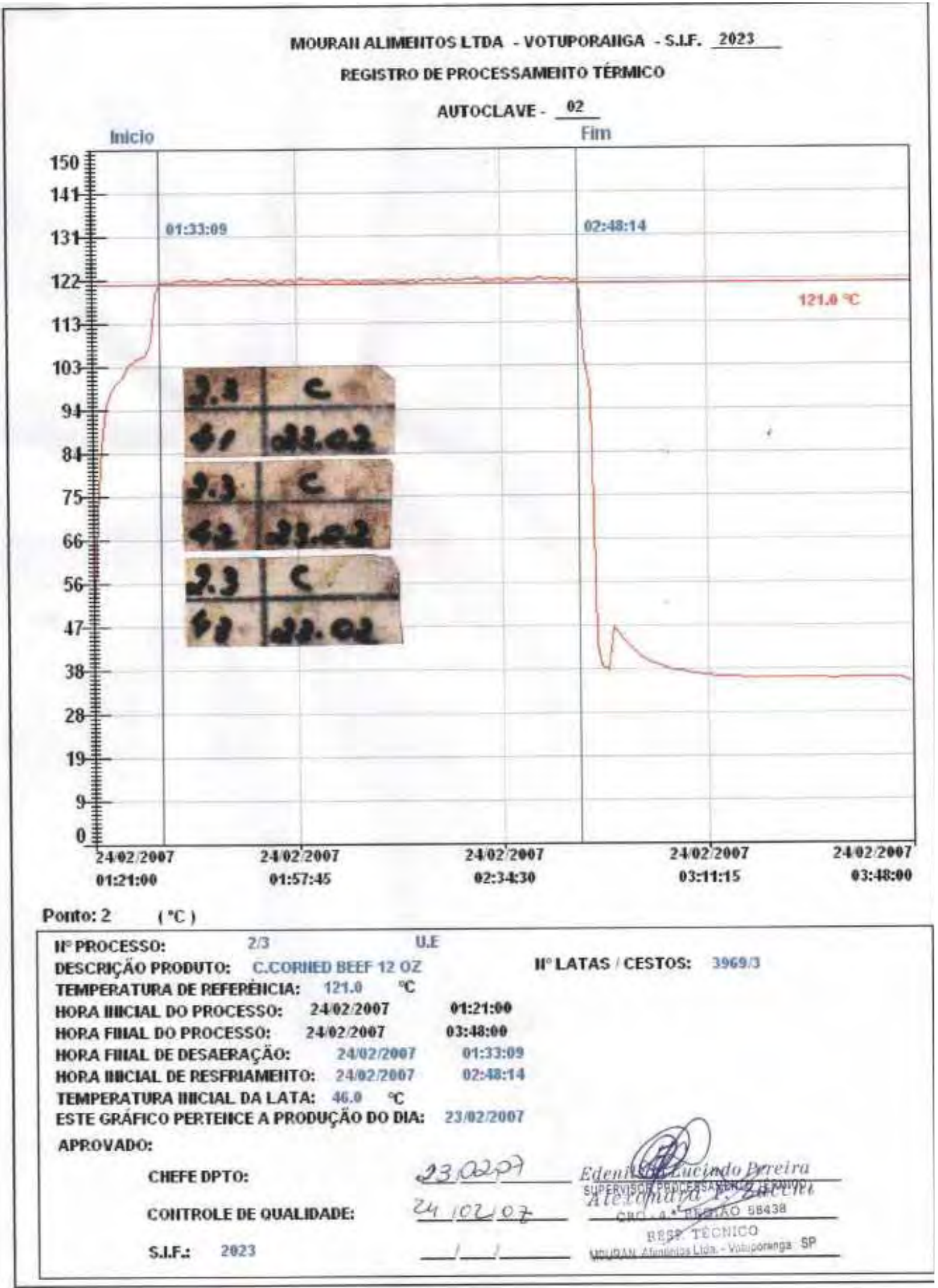



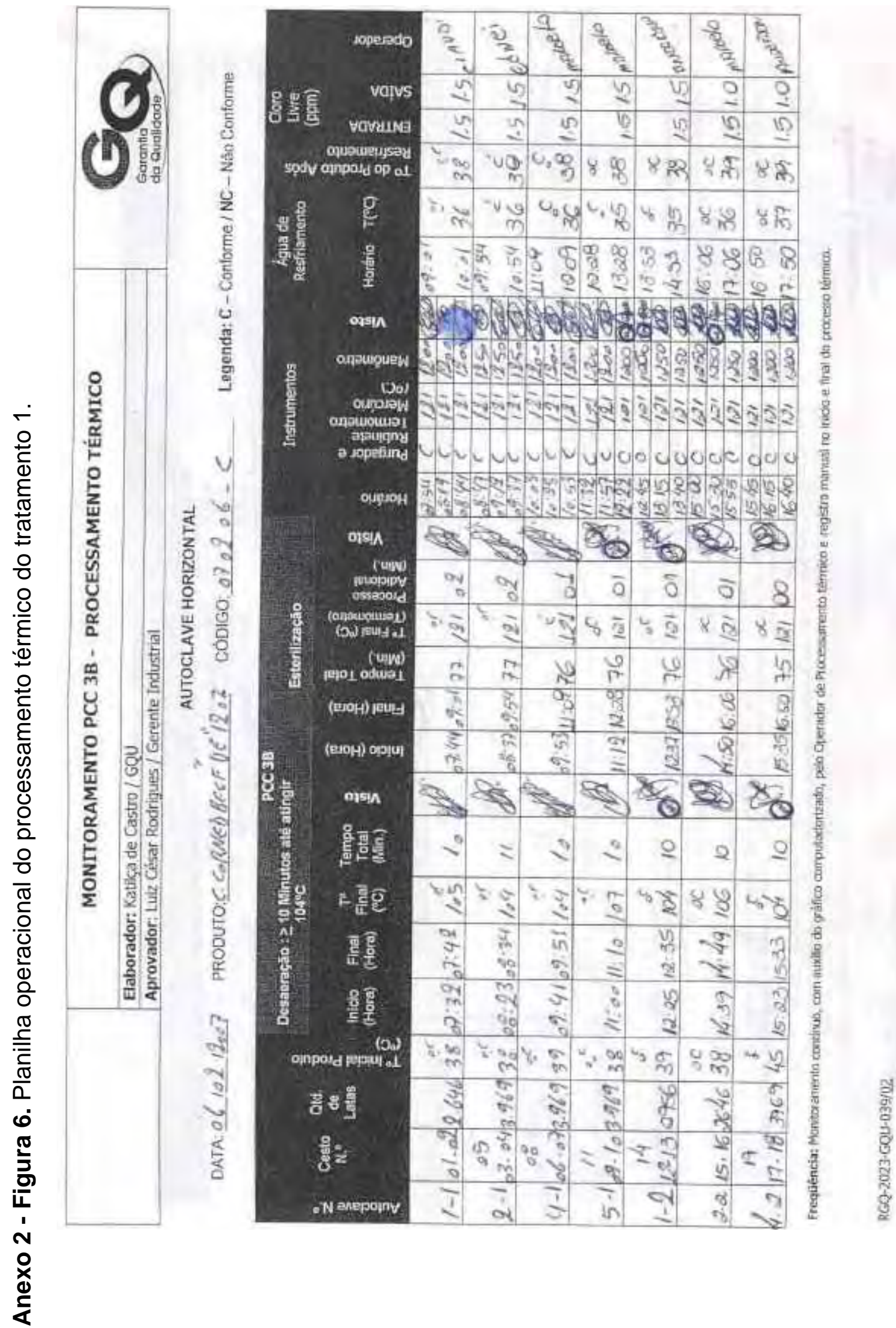


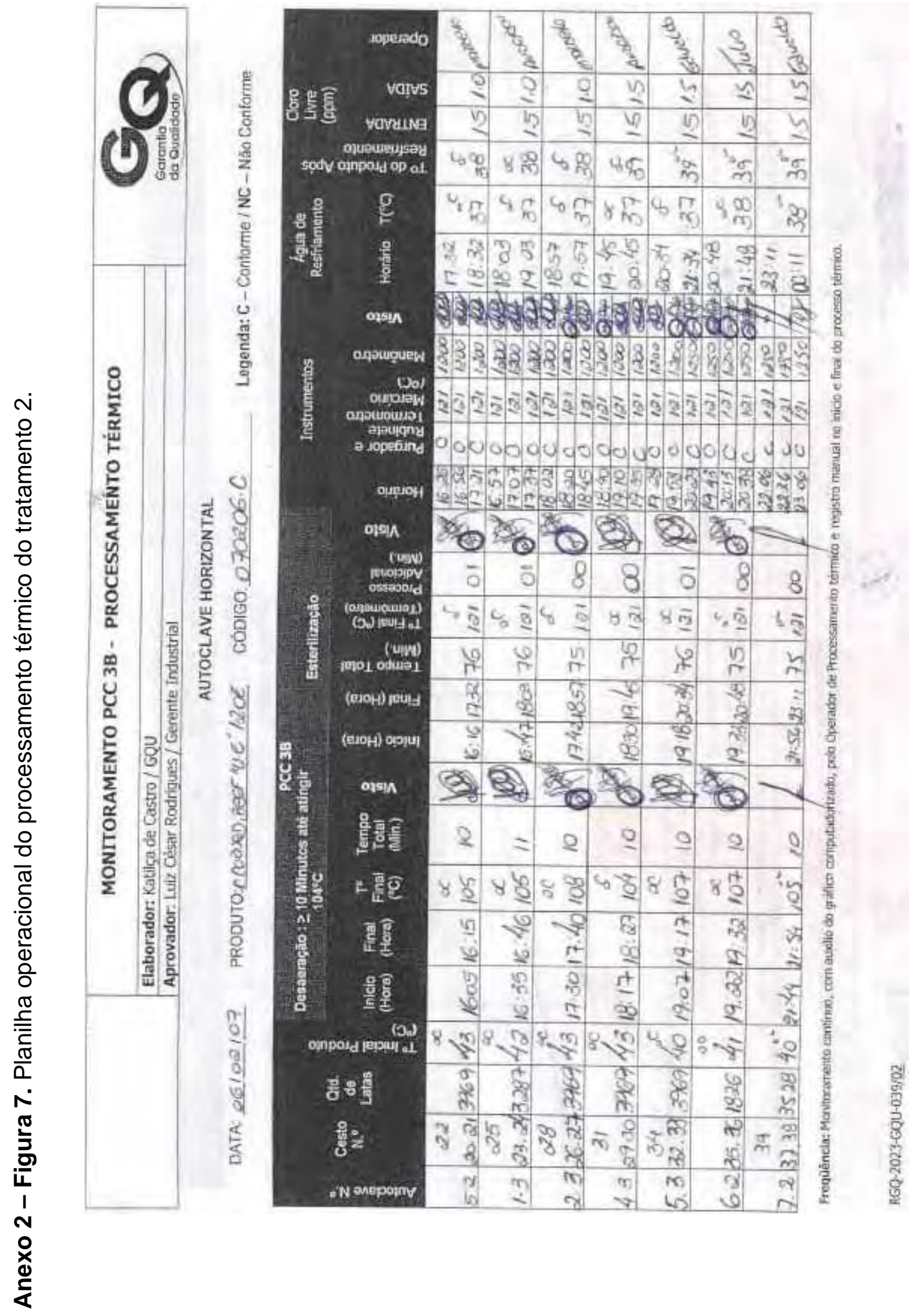



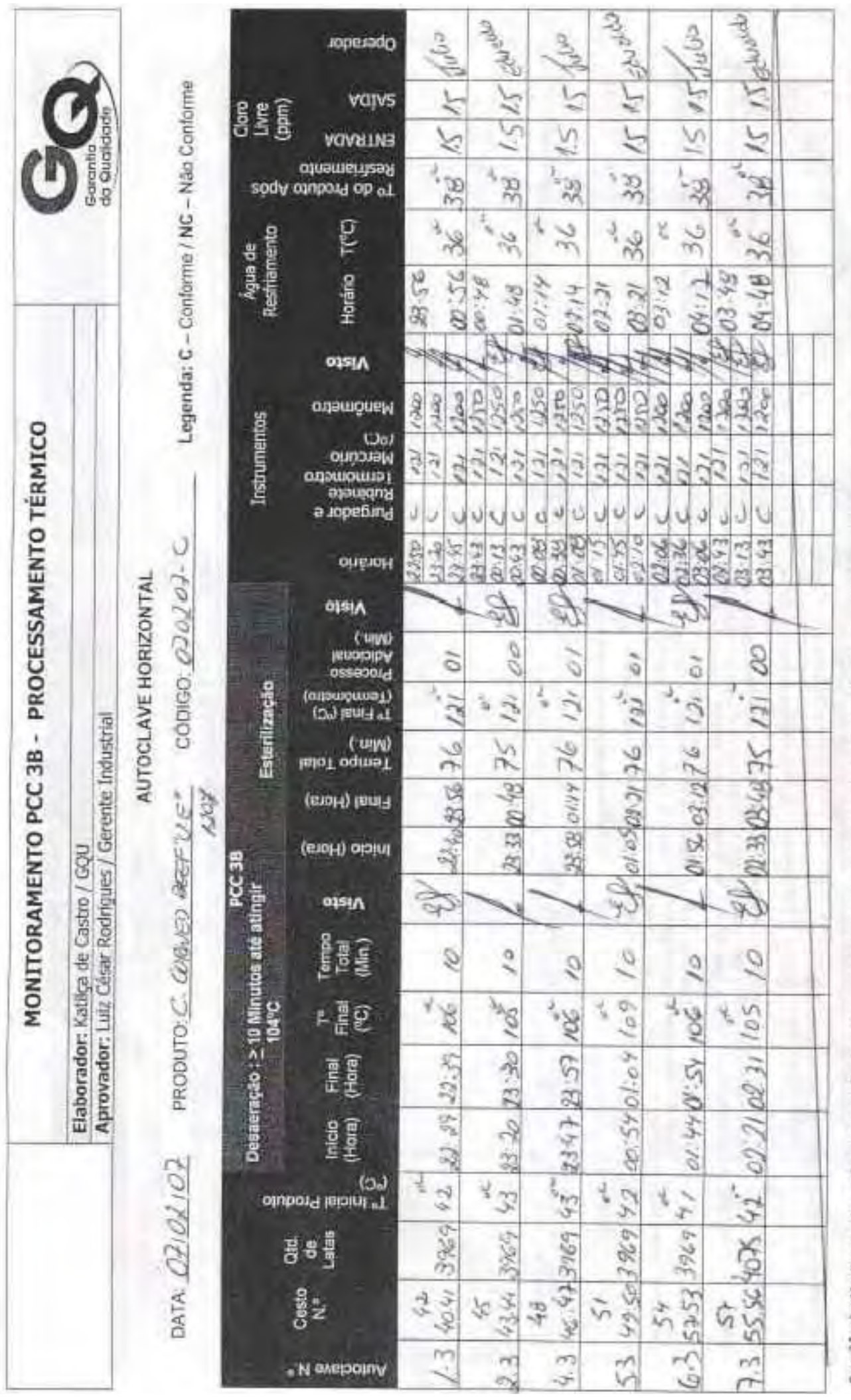


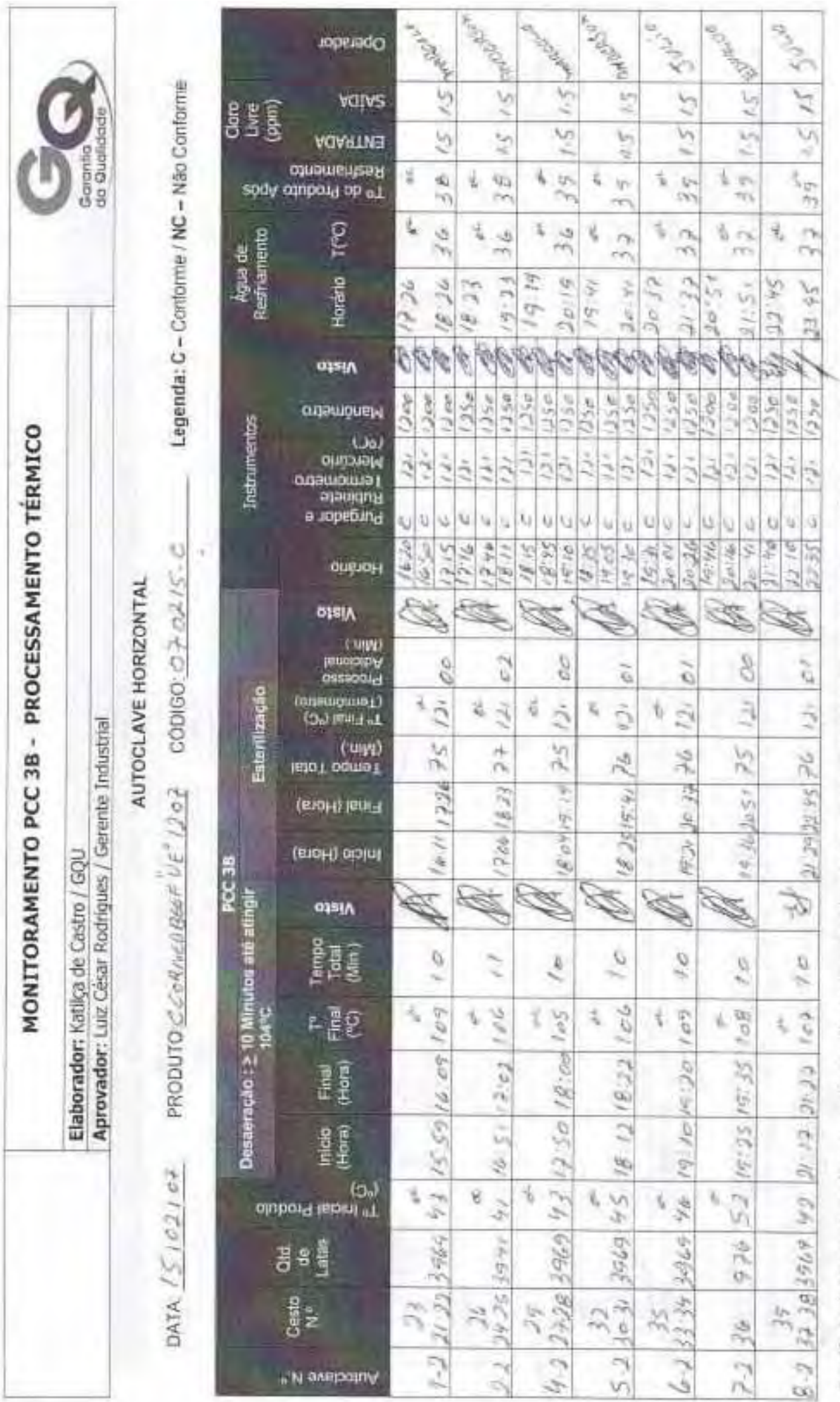




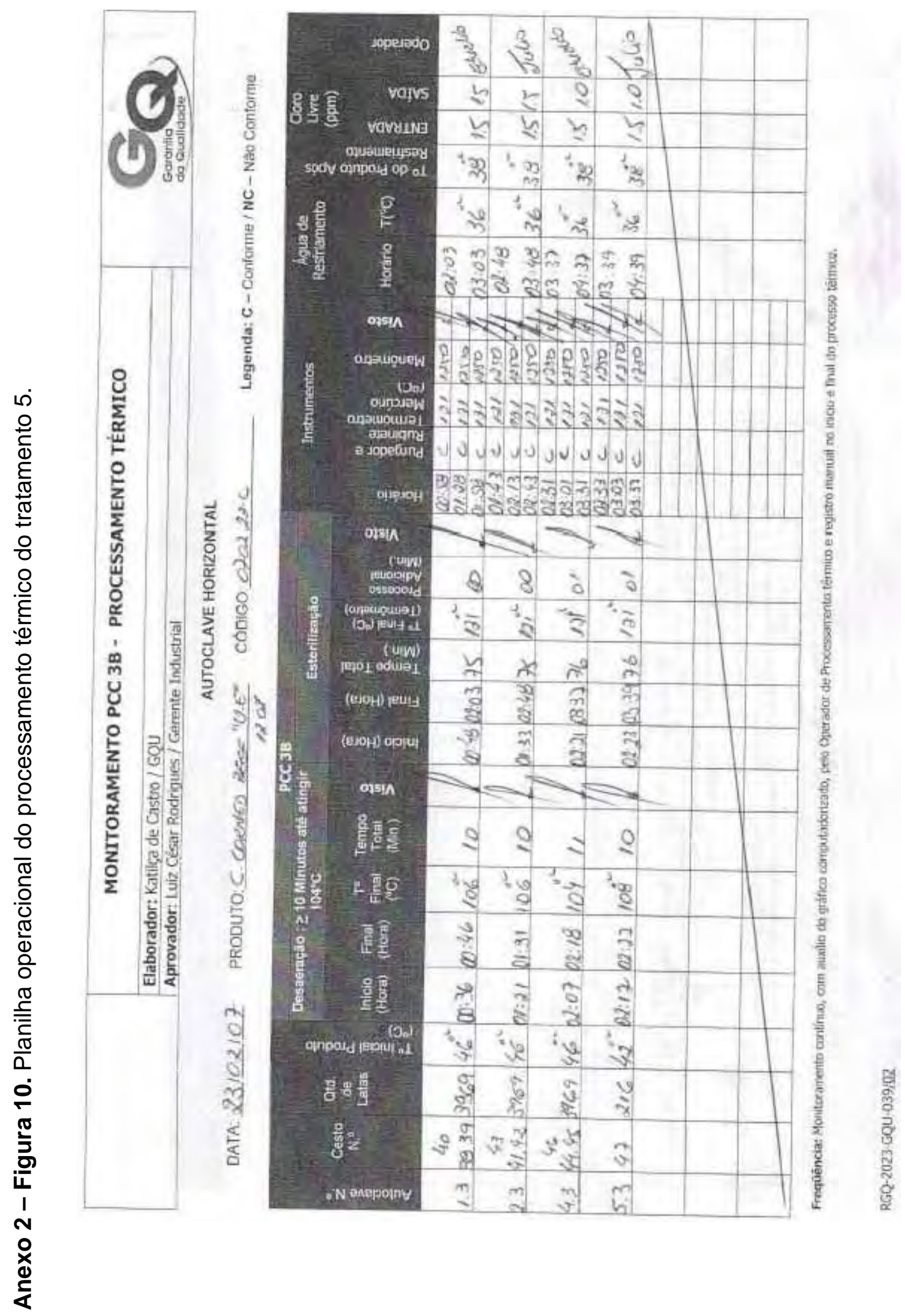




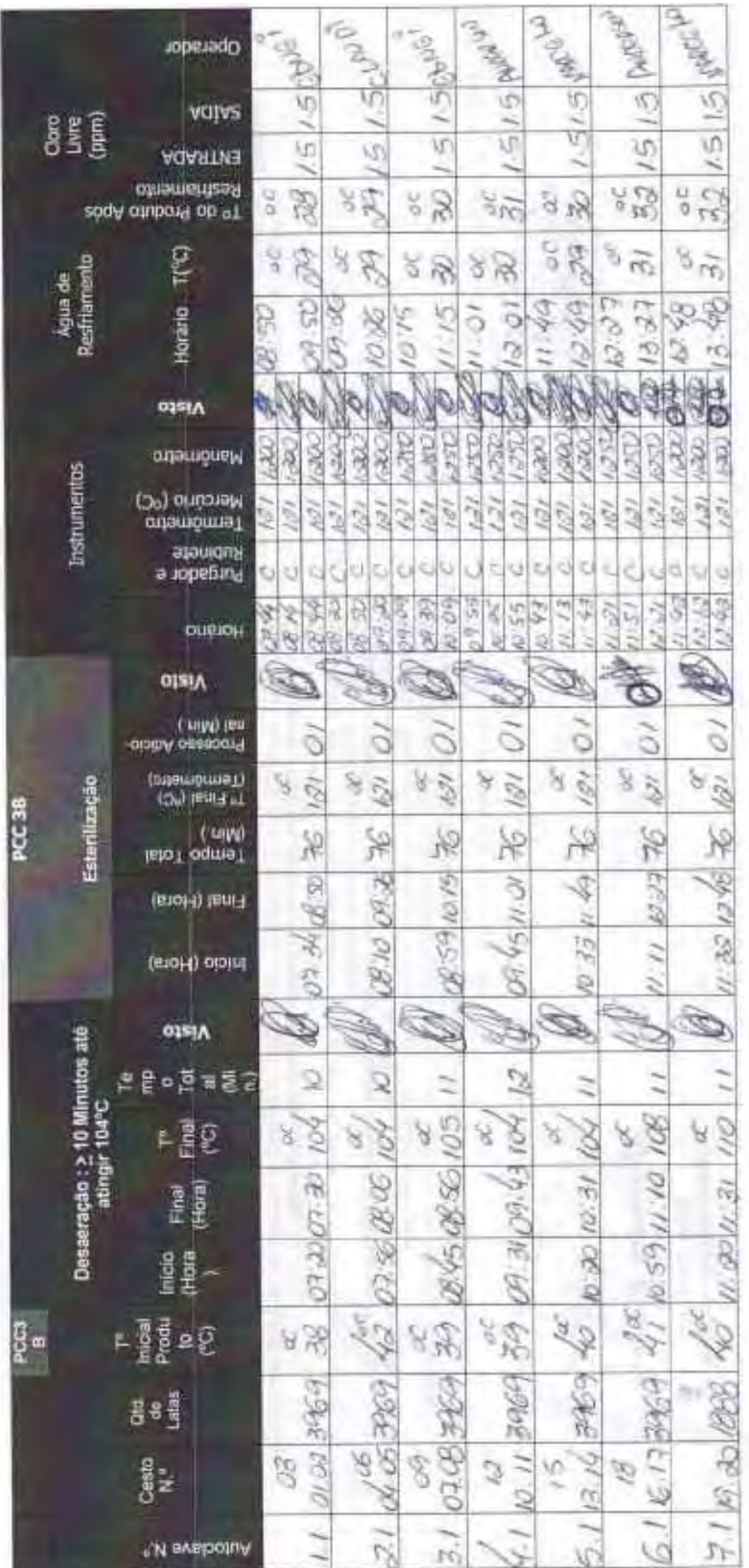




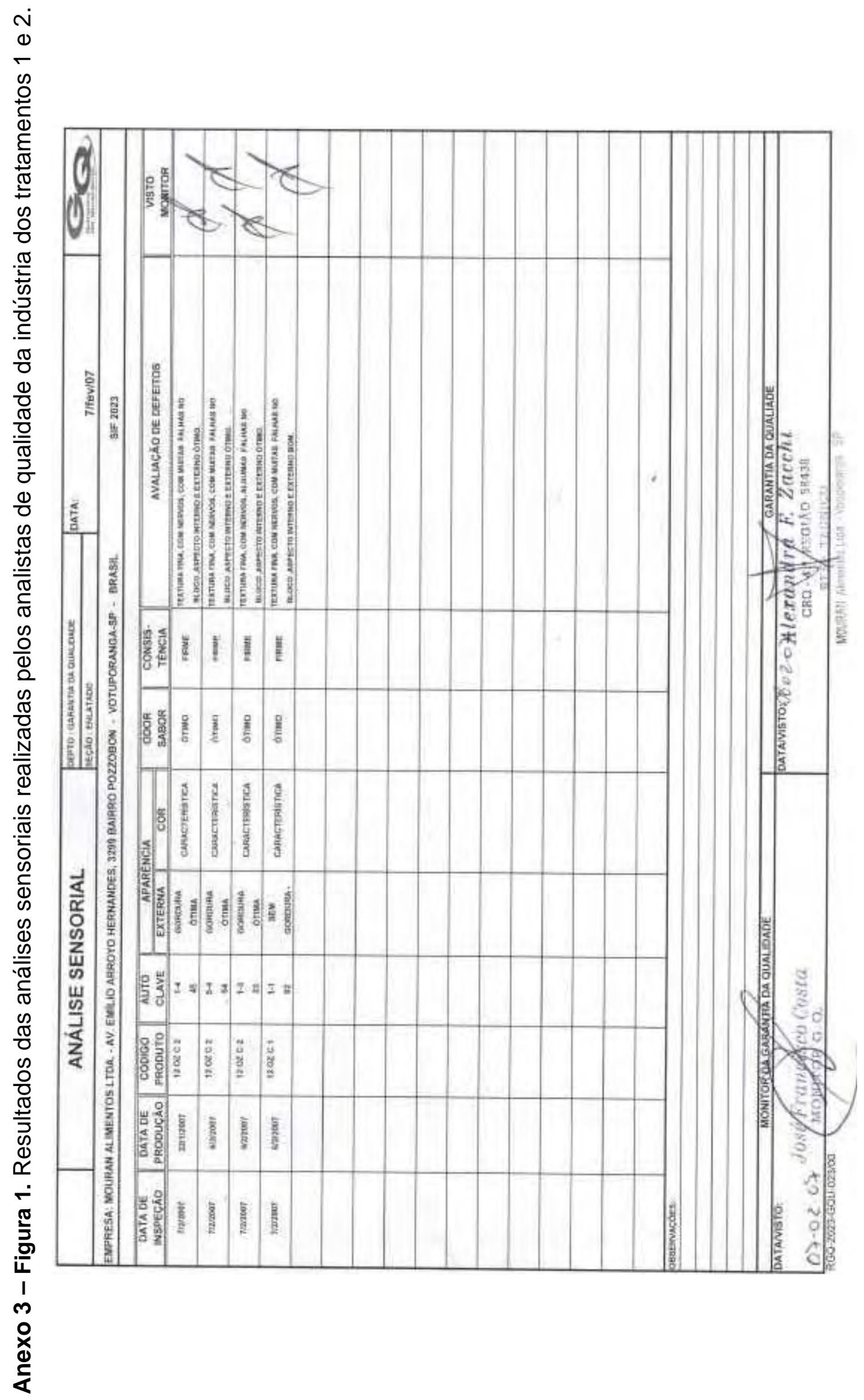




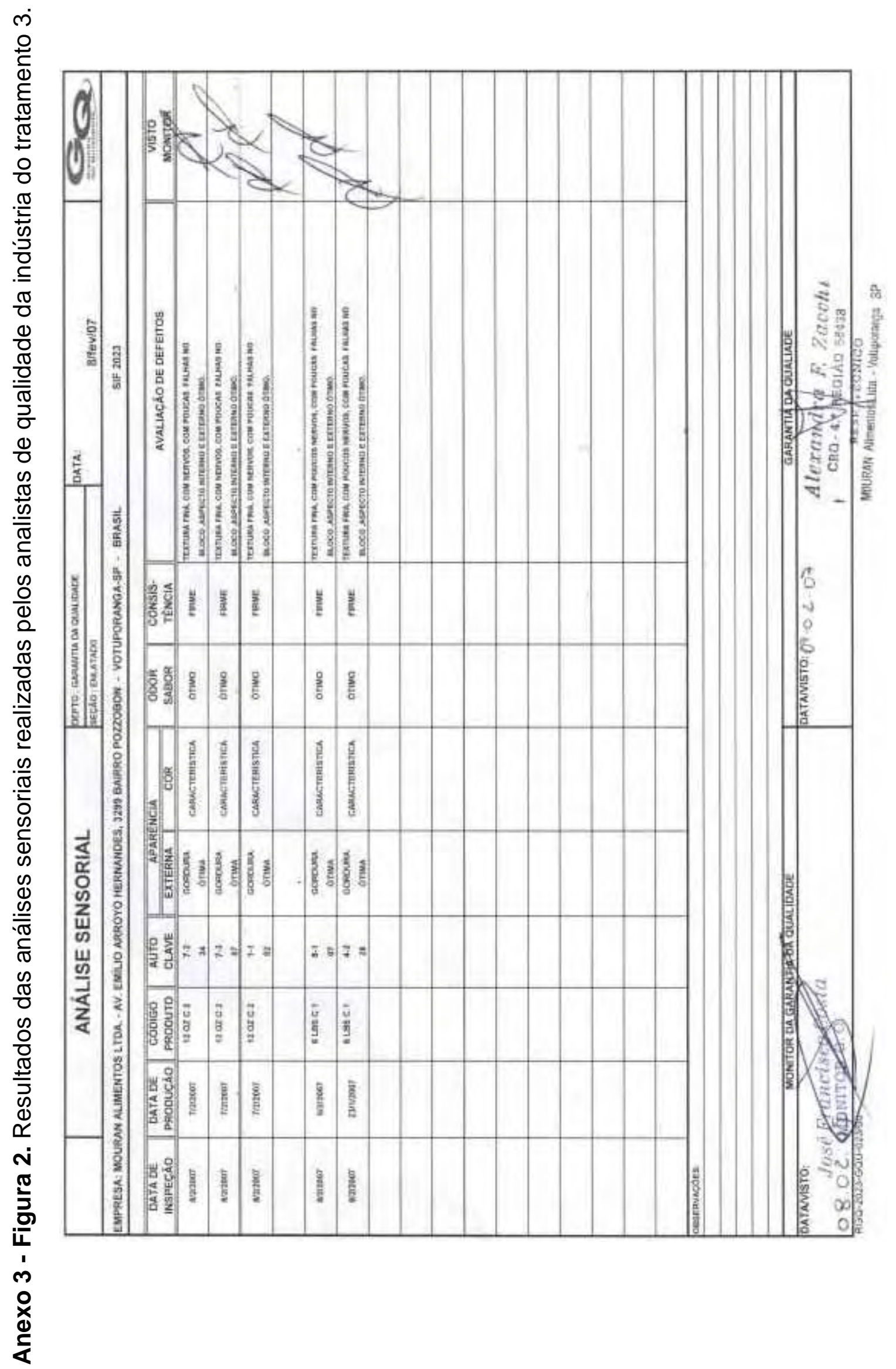




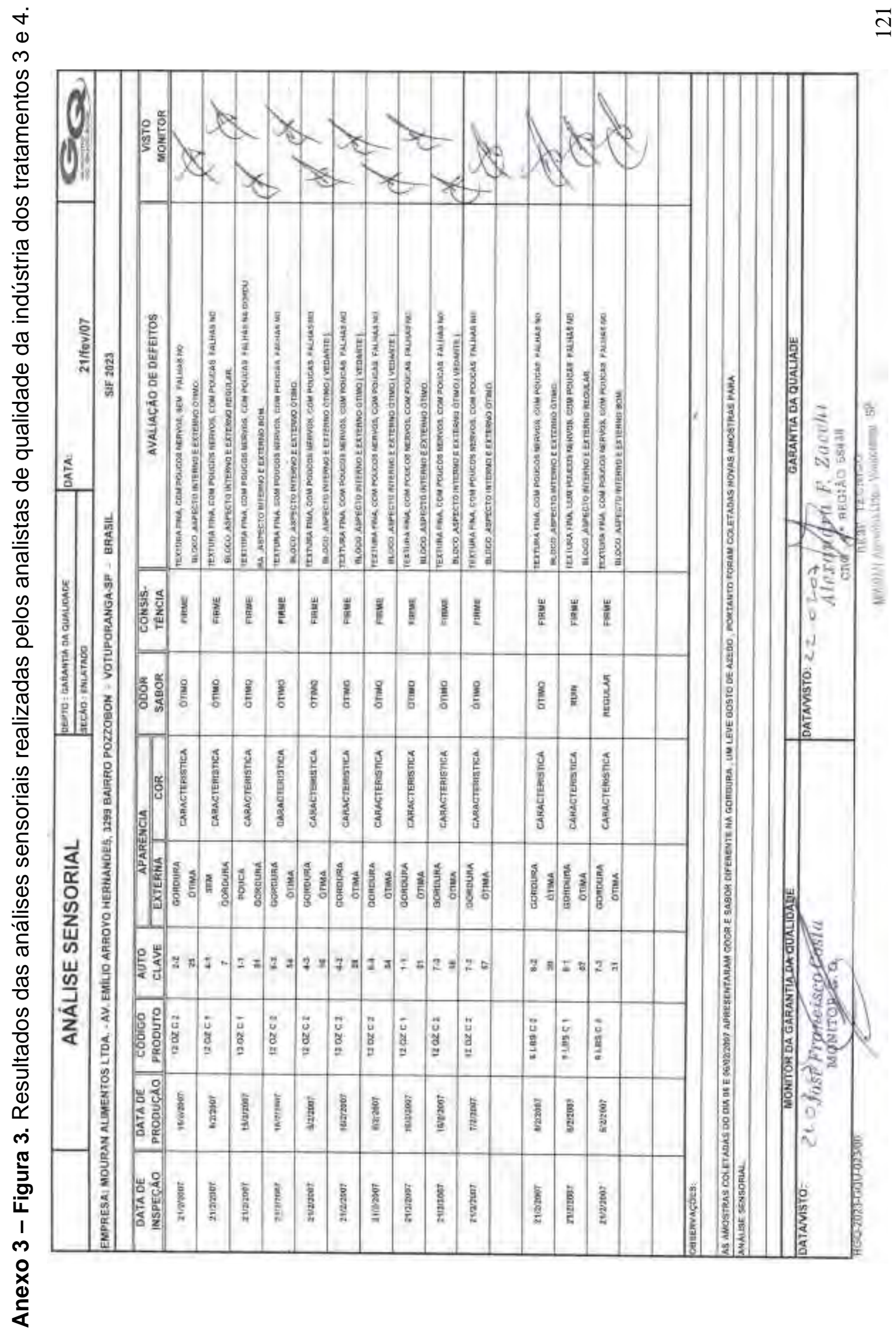




\section{Anexo 3 - Figura 4. Resultados das análises sensoriais realizadas pelos analistas de qualidade da indústria do tratamento 5 .}

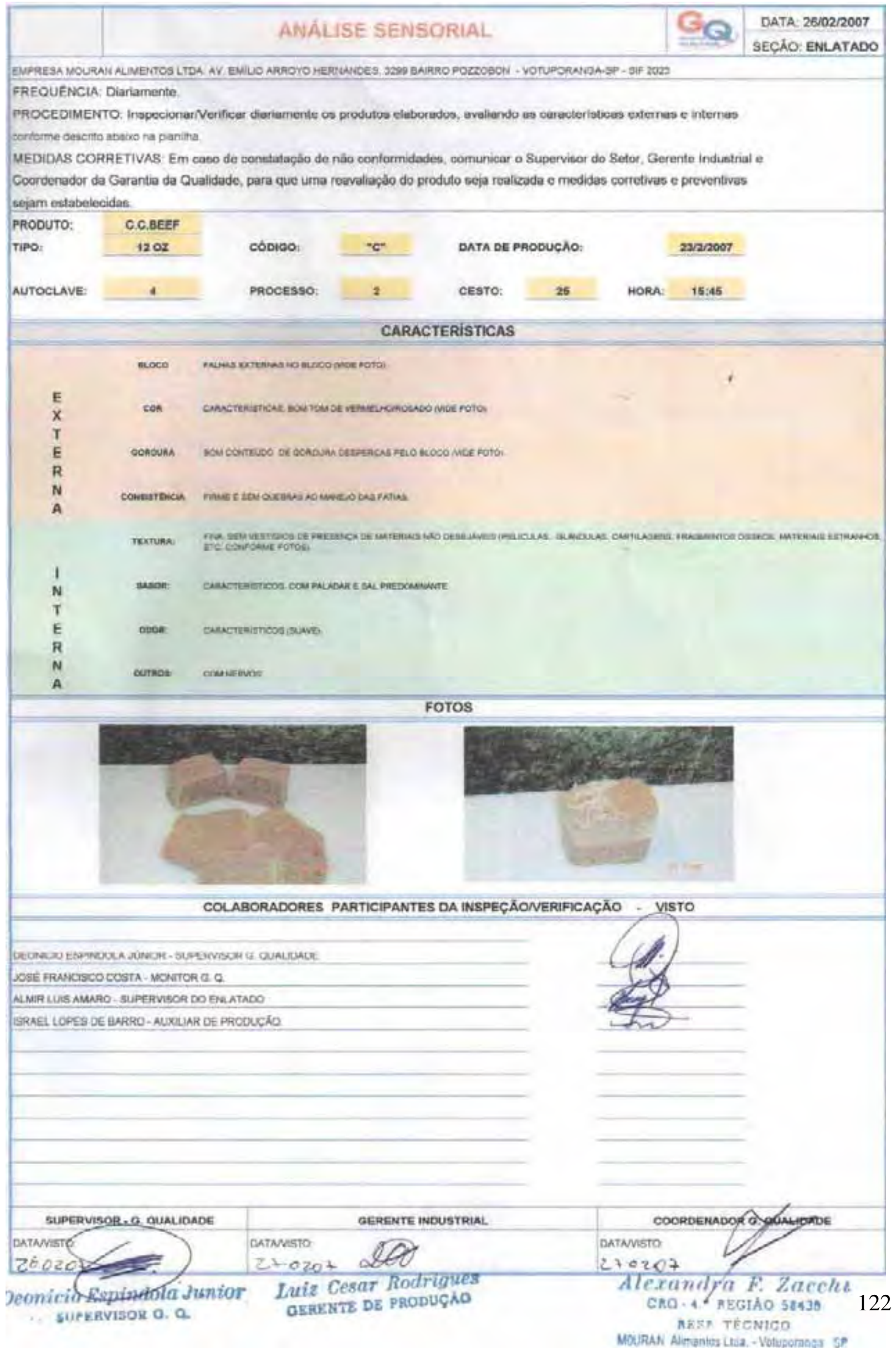




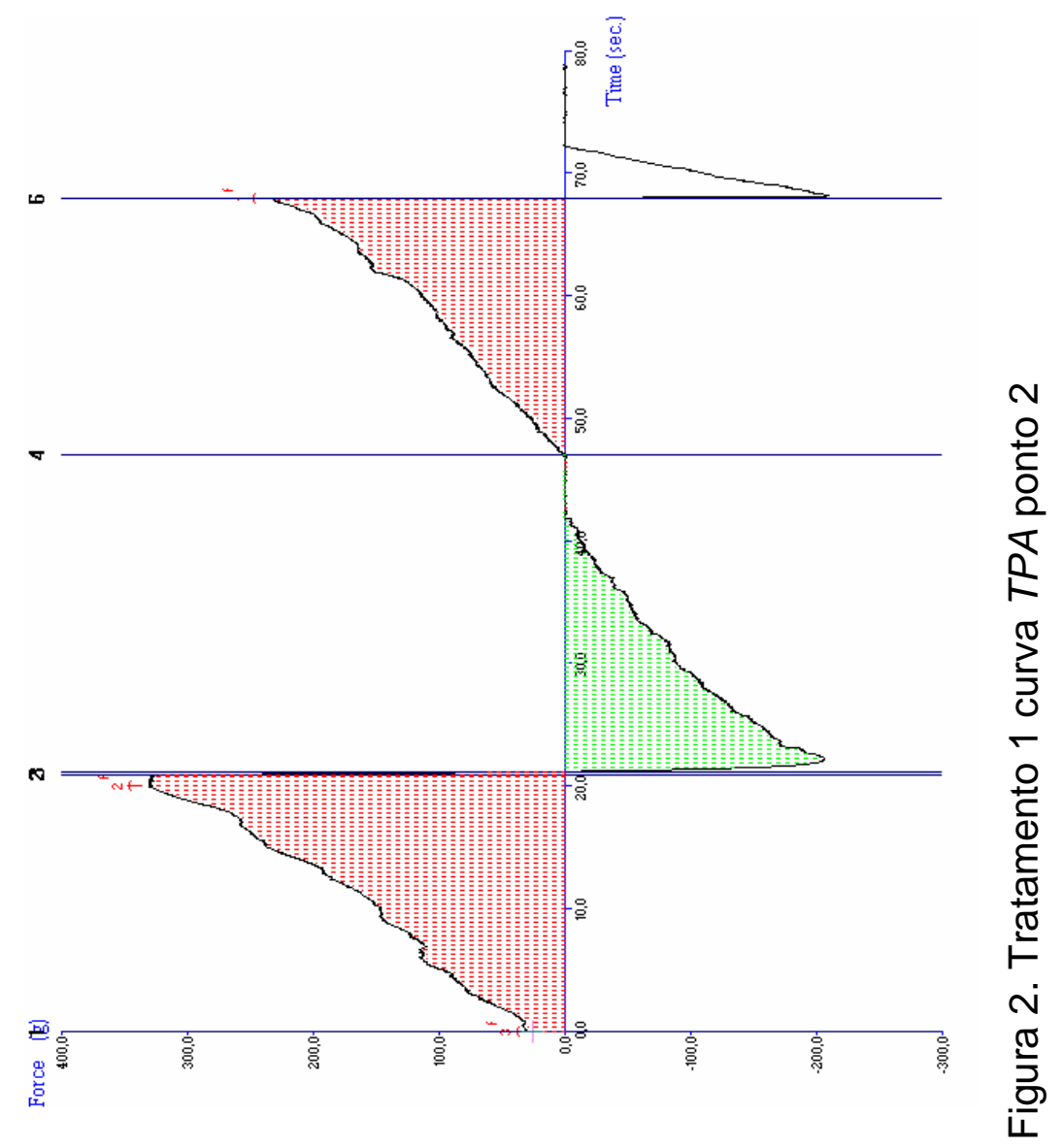

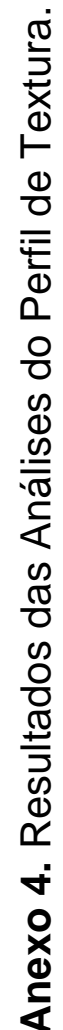

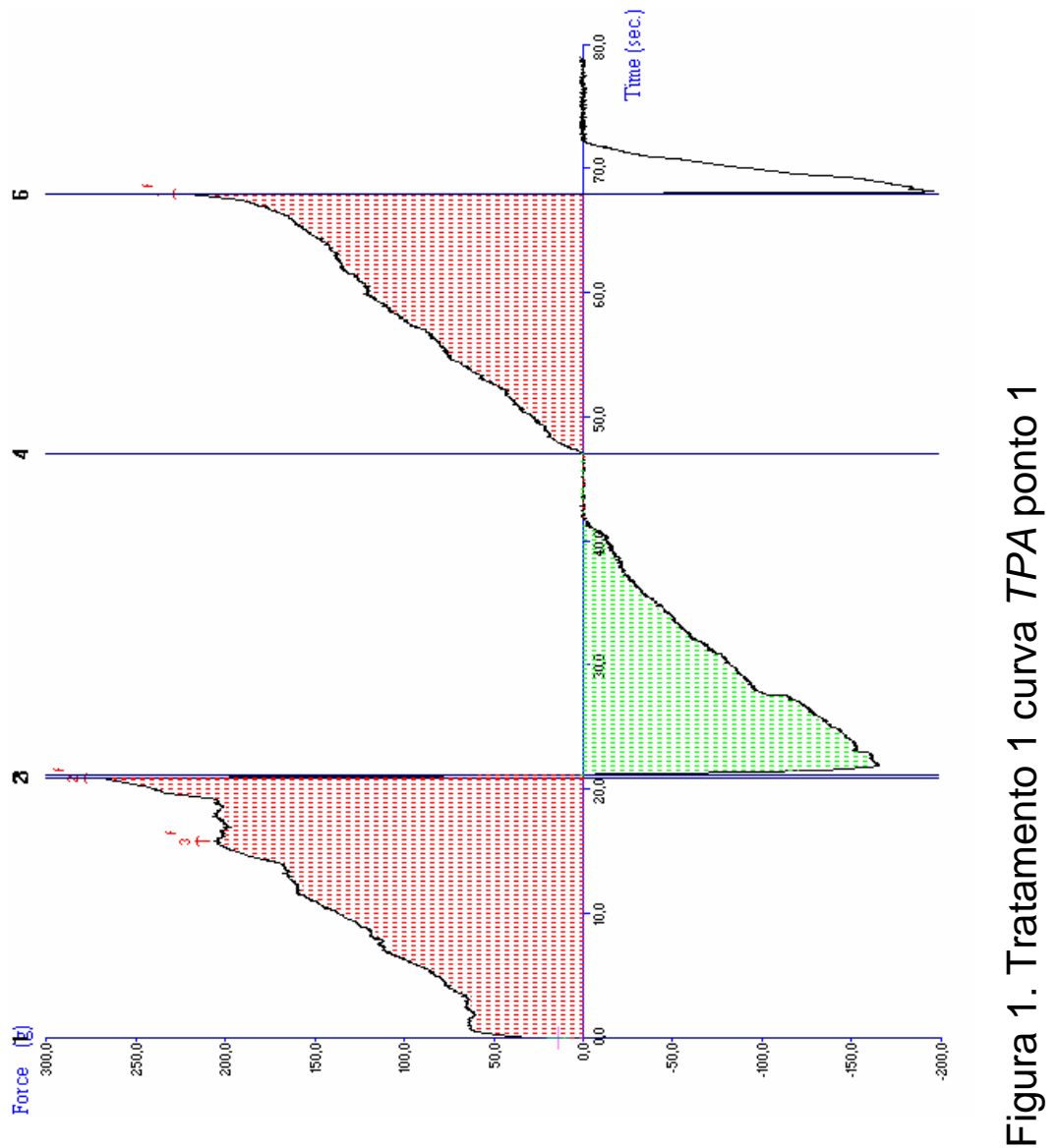



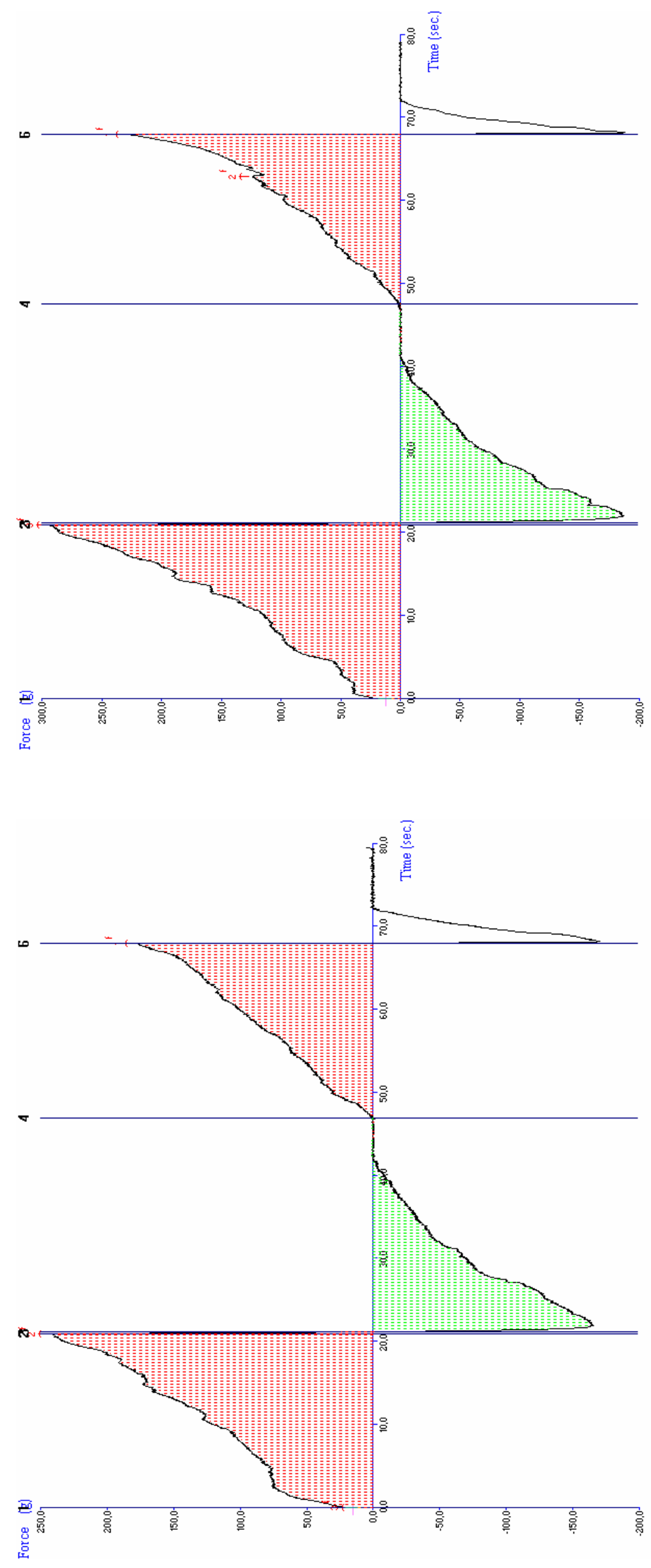

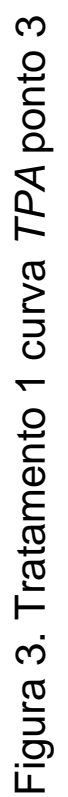



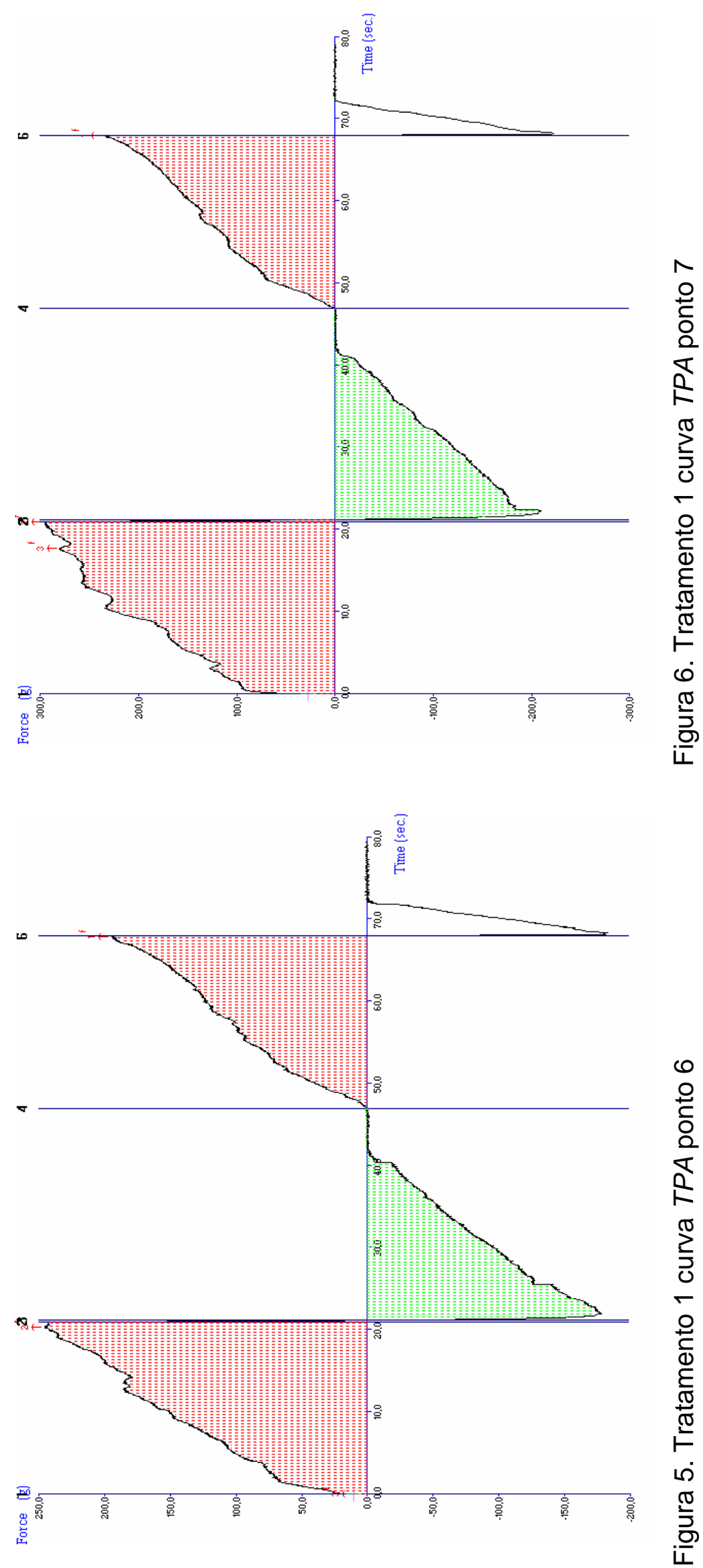

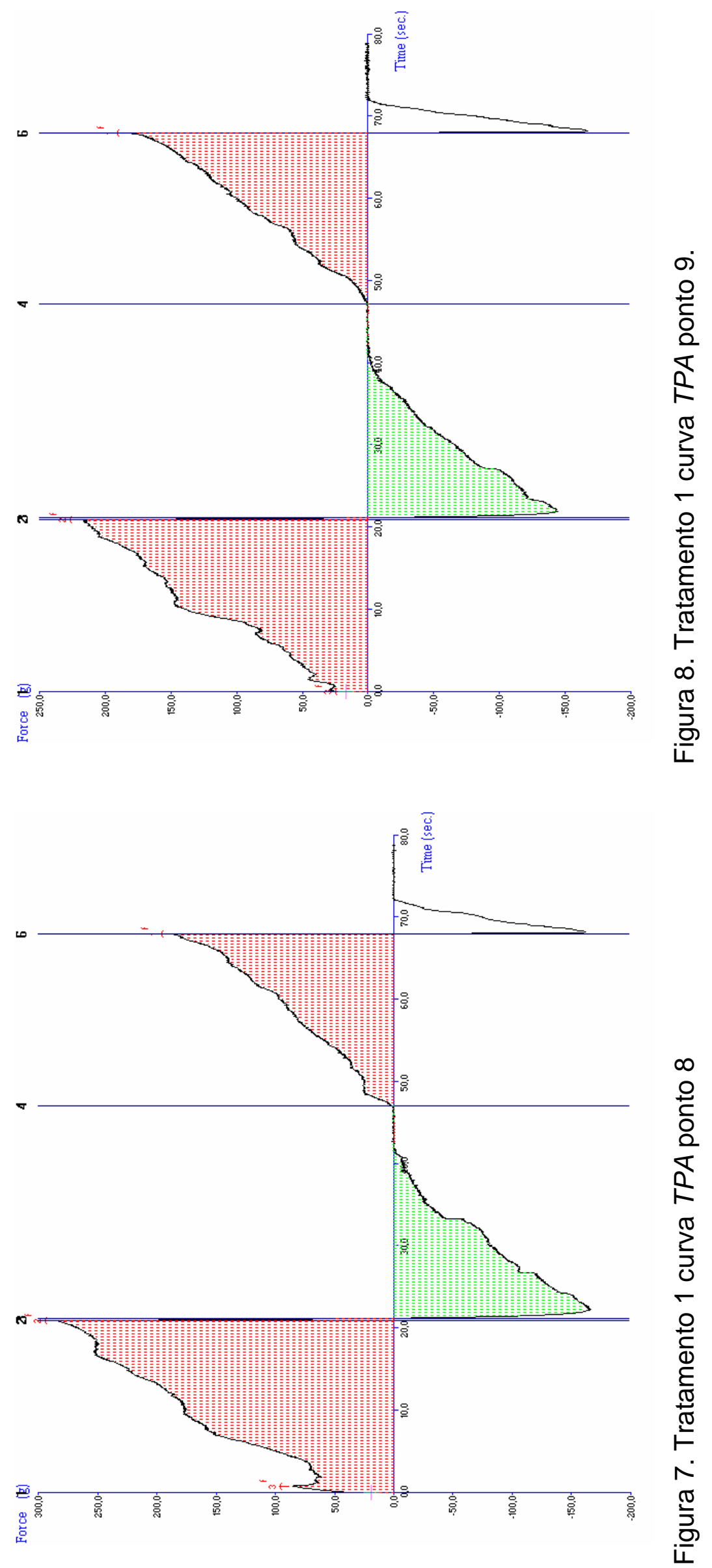

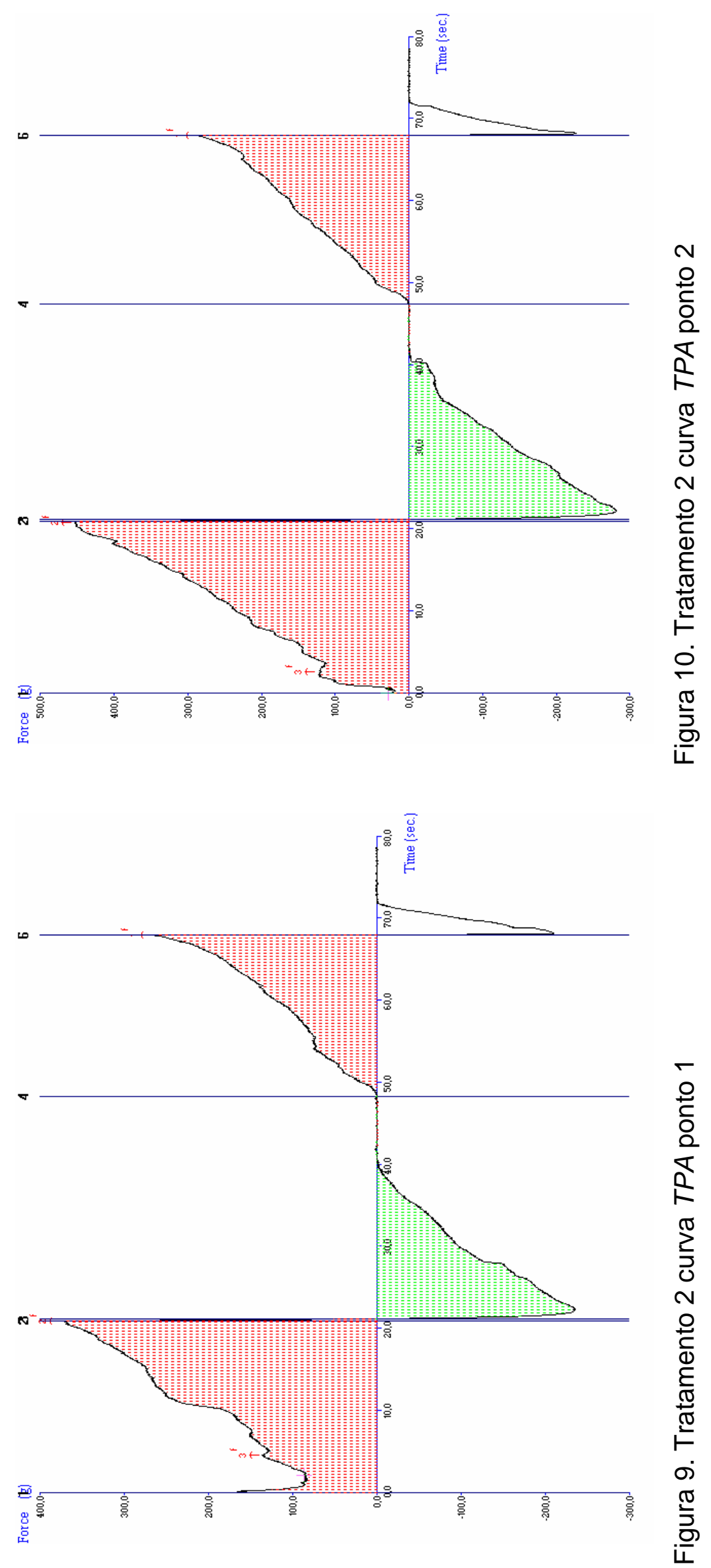

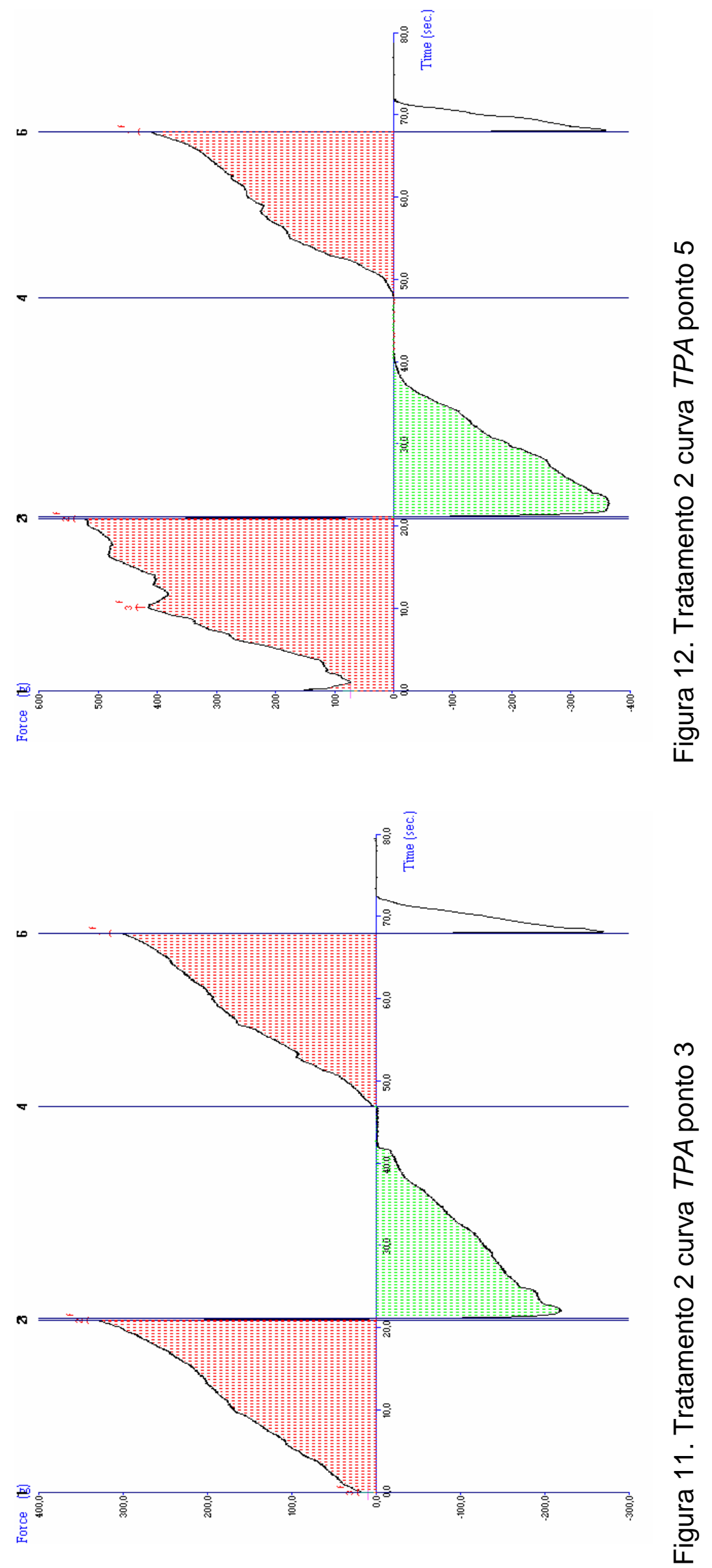

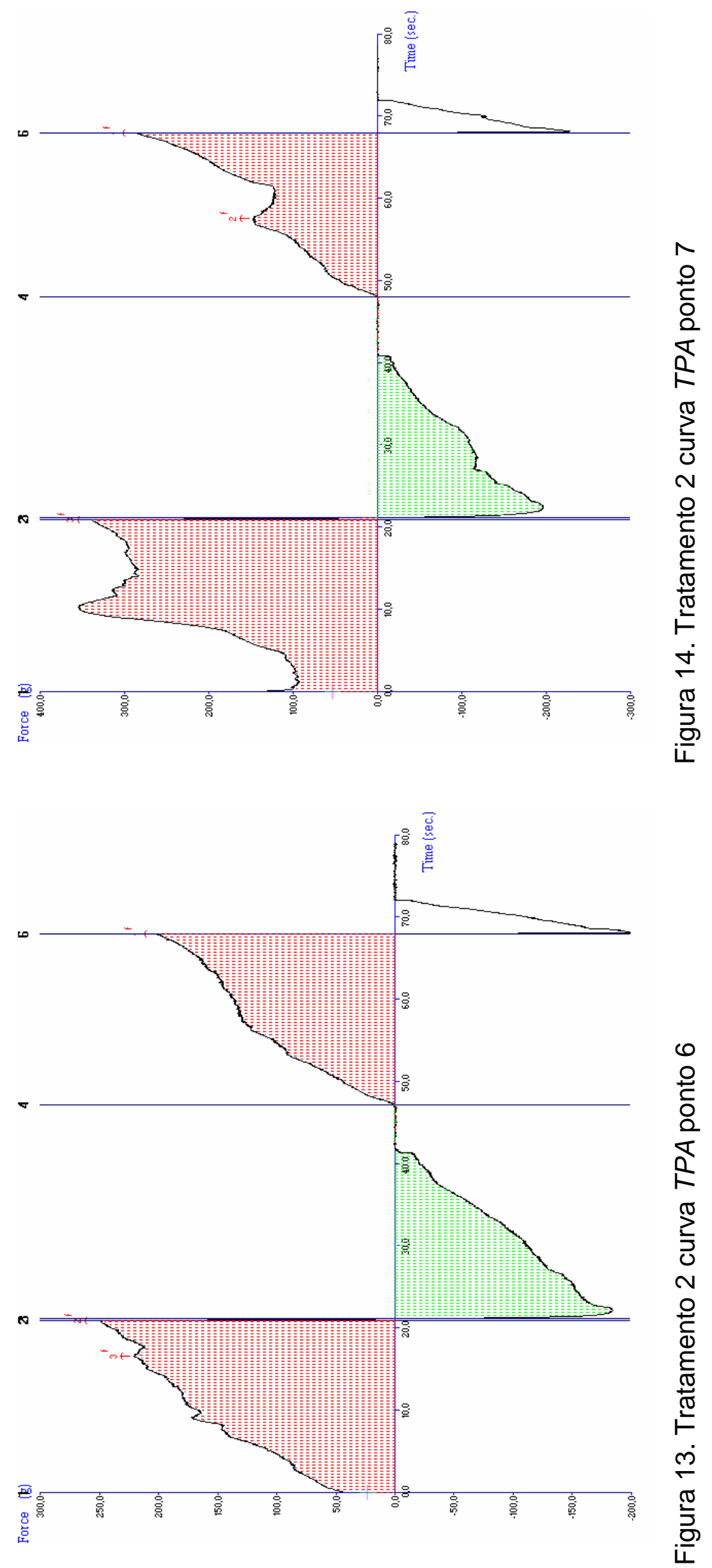

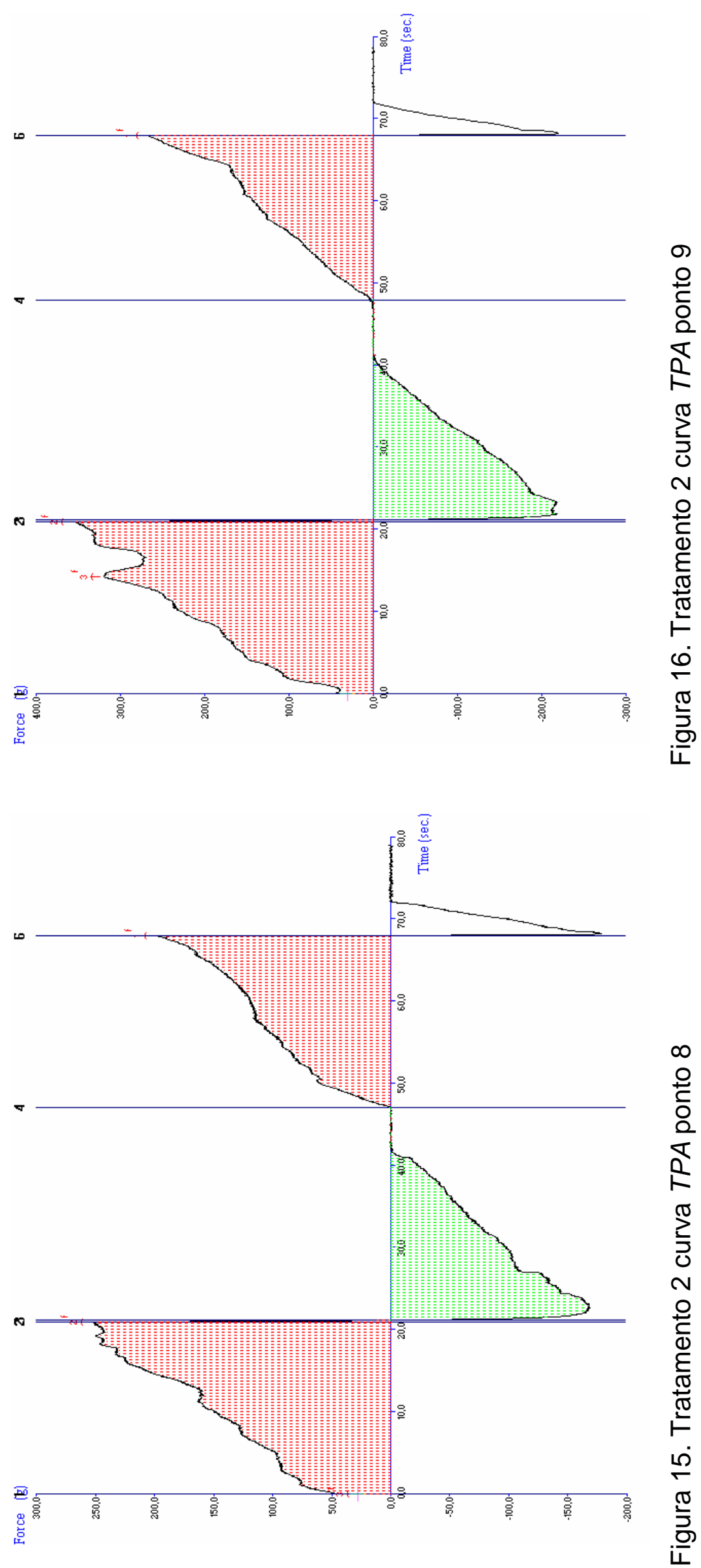

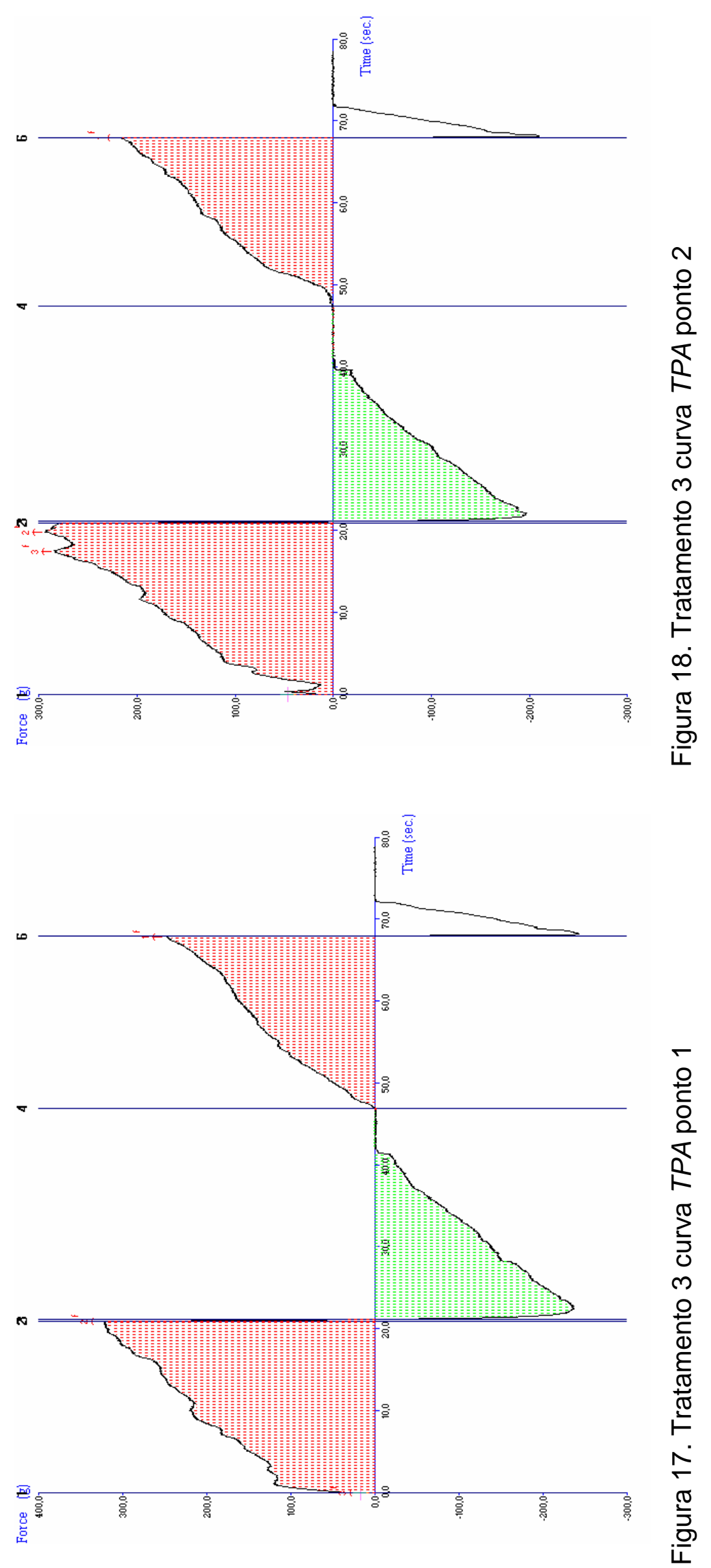

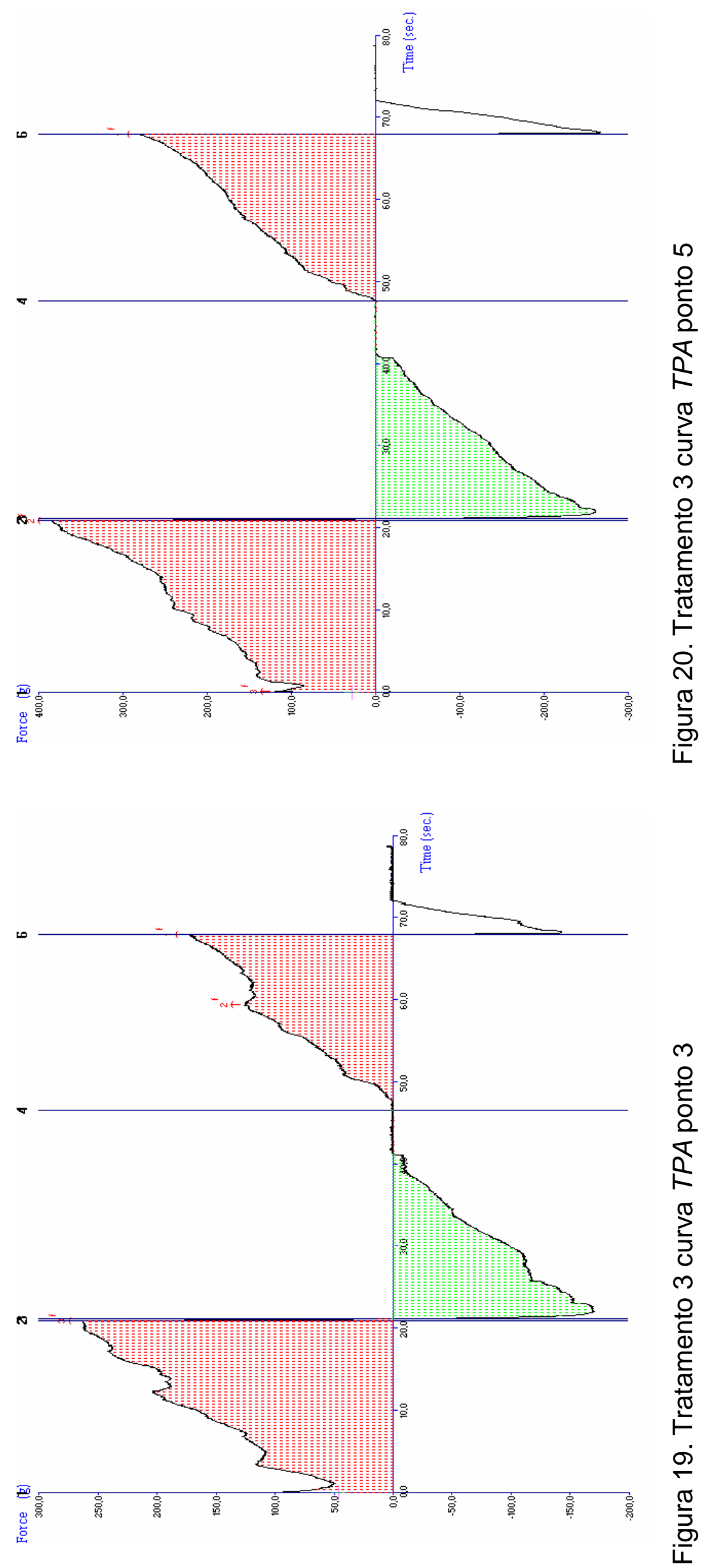

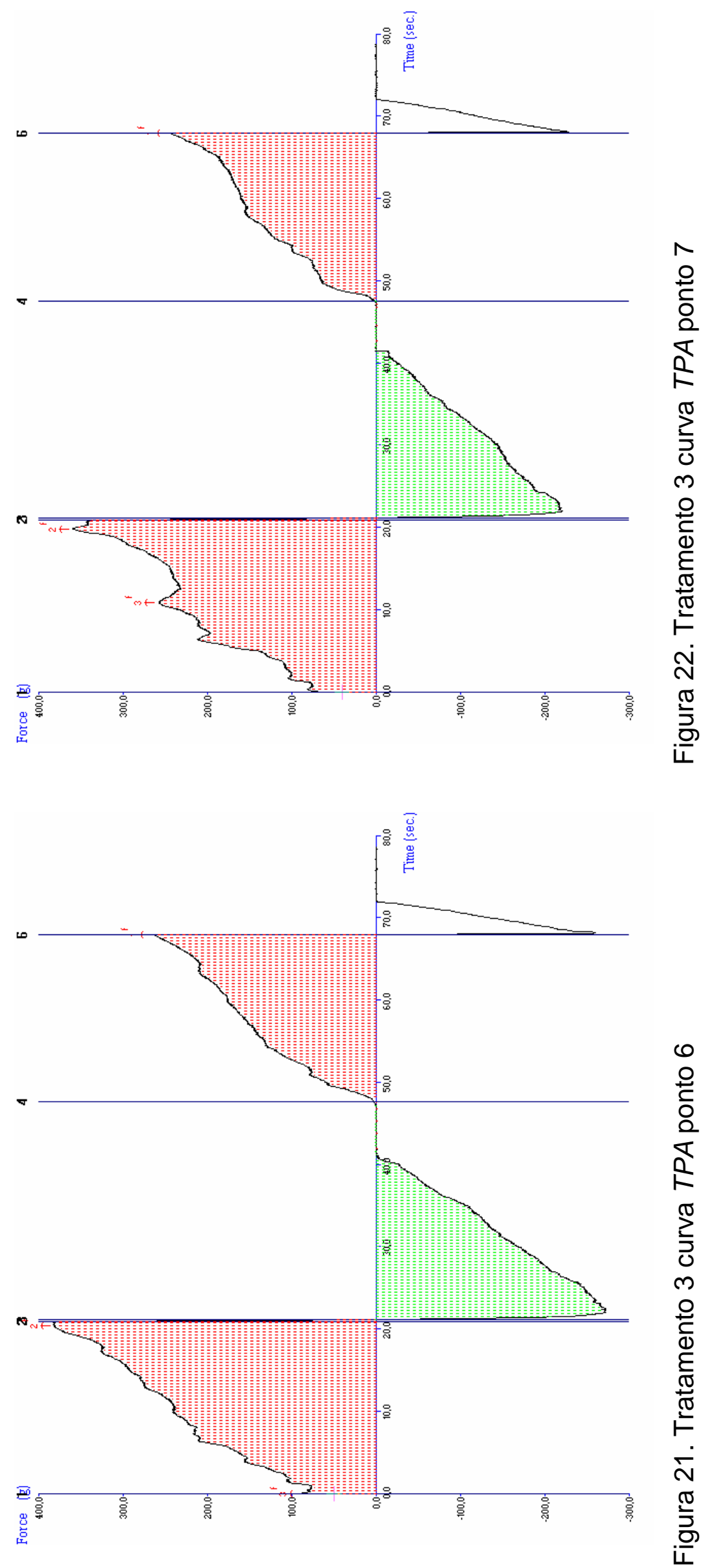

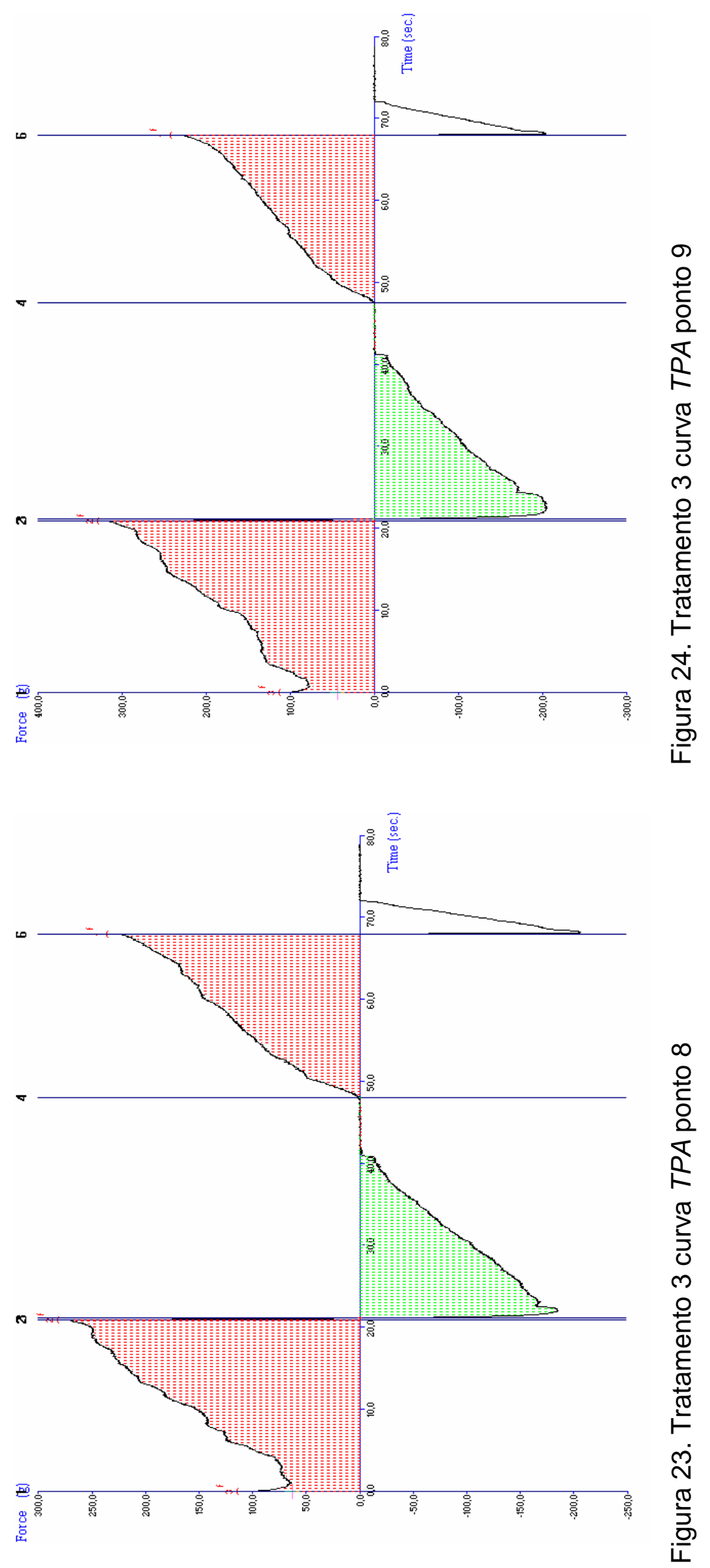

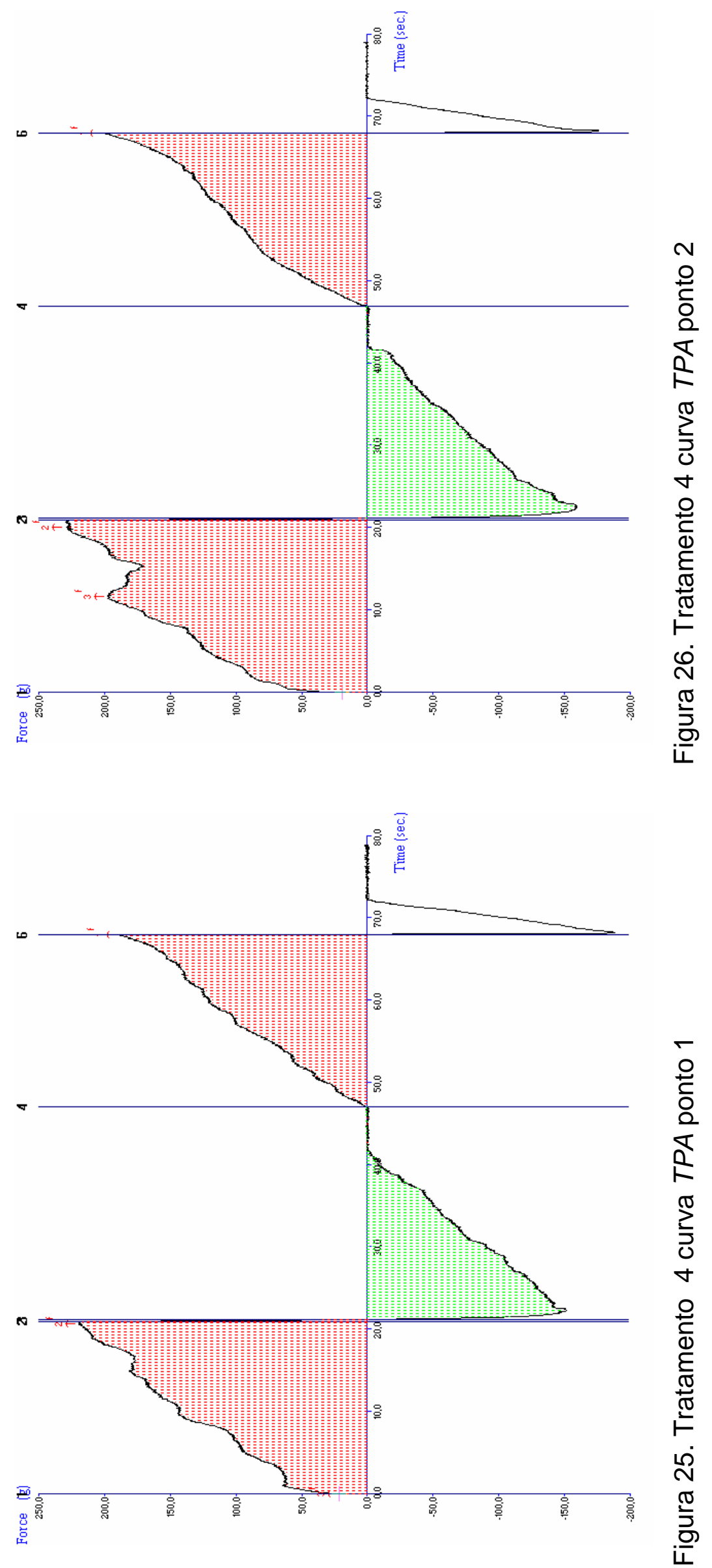

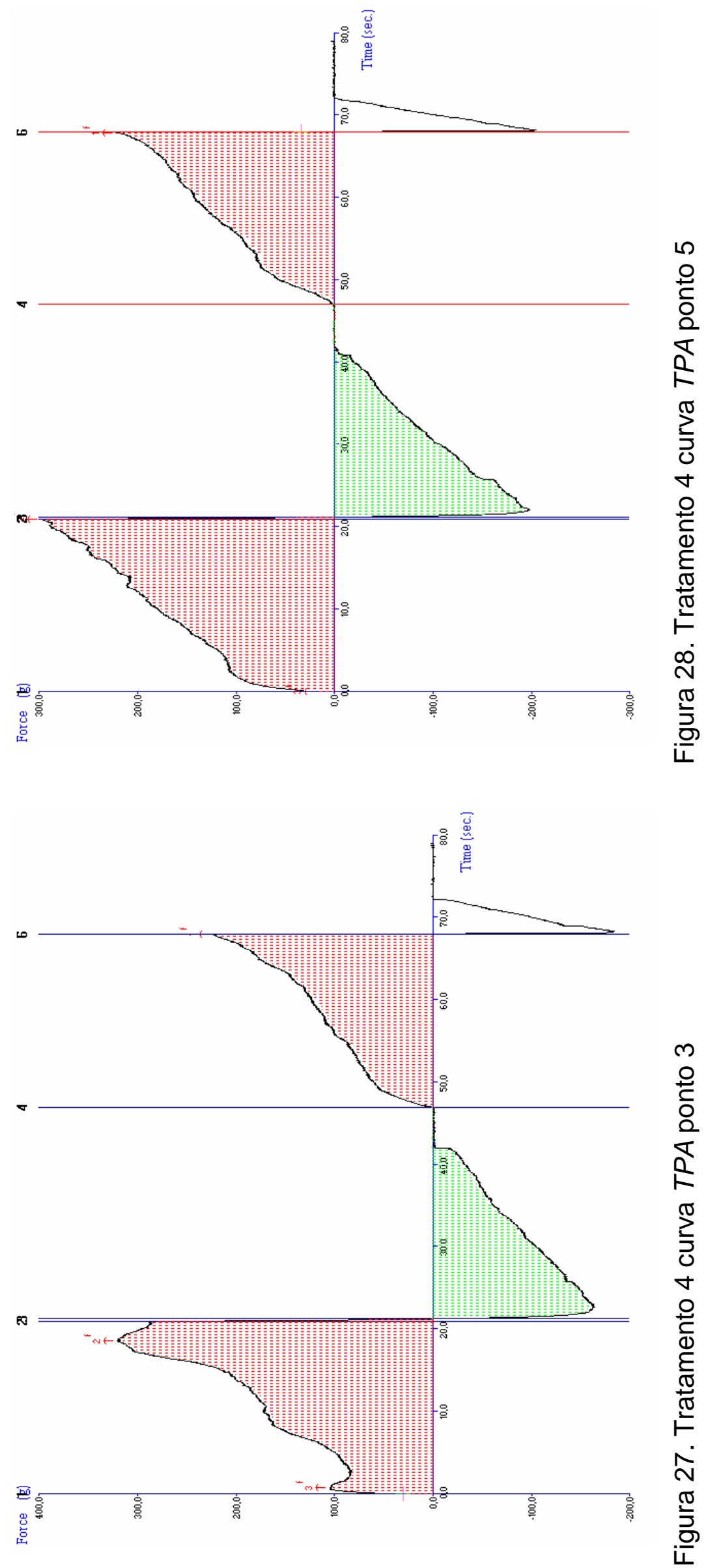

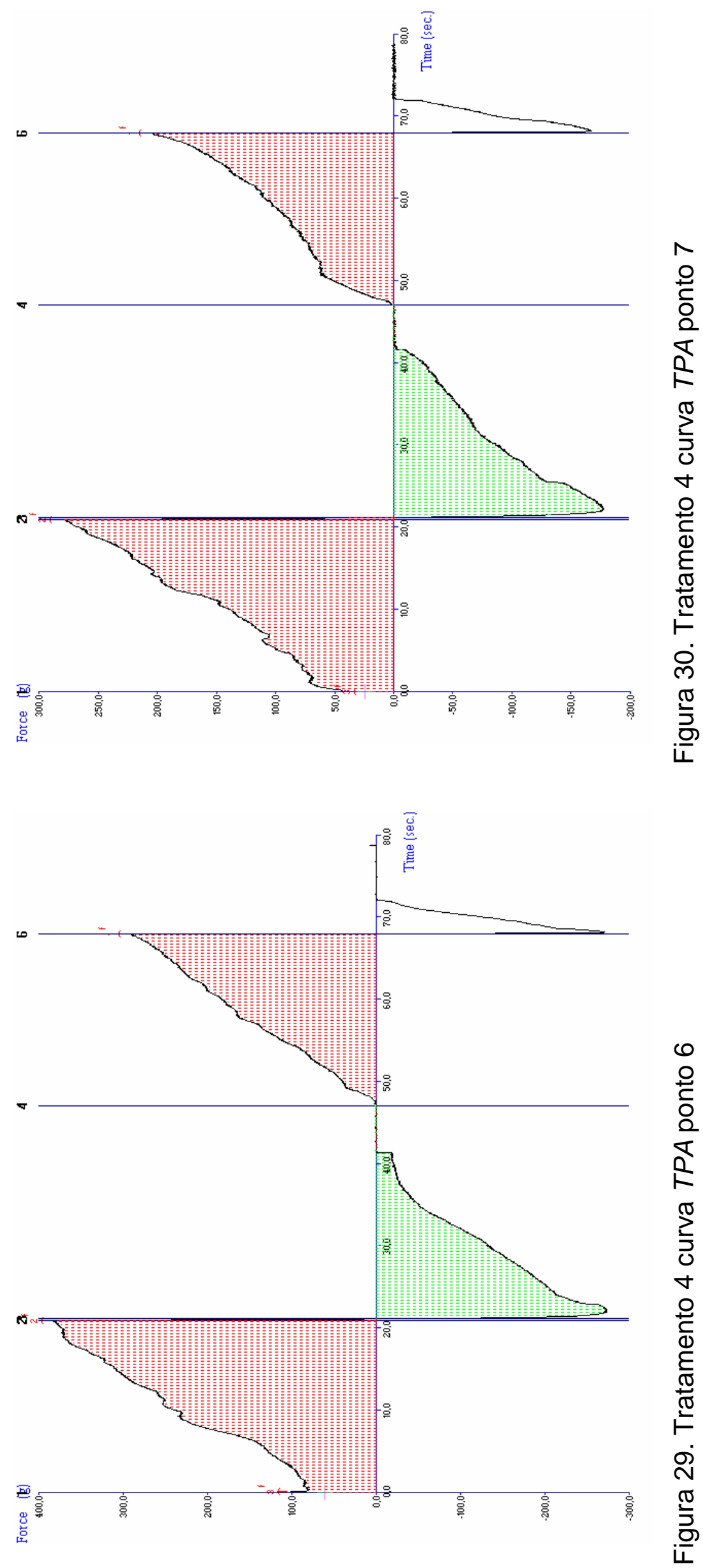

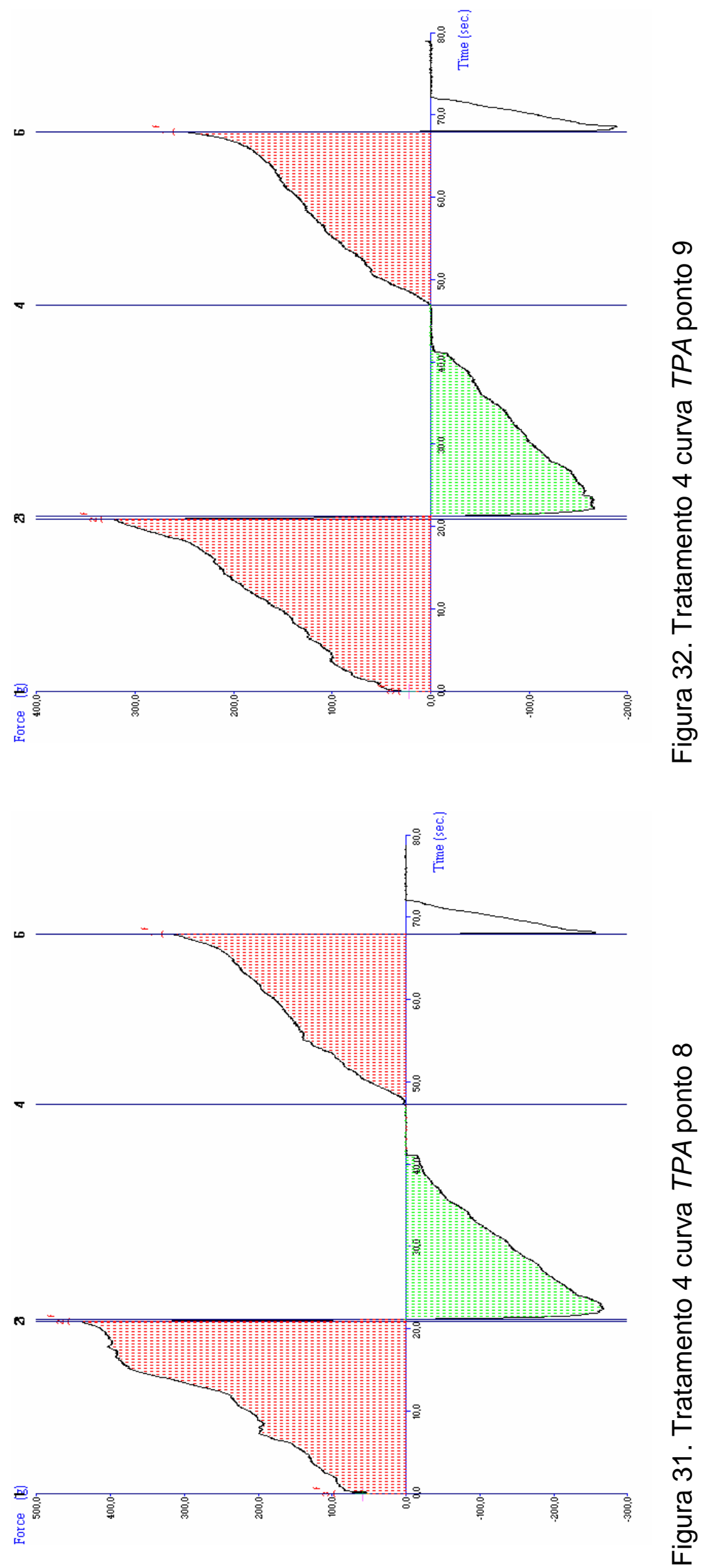

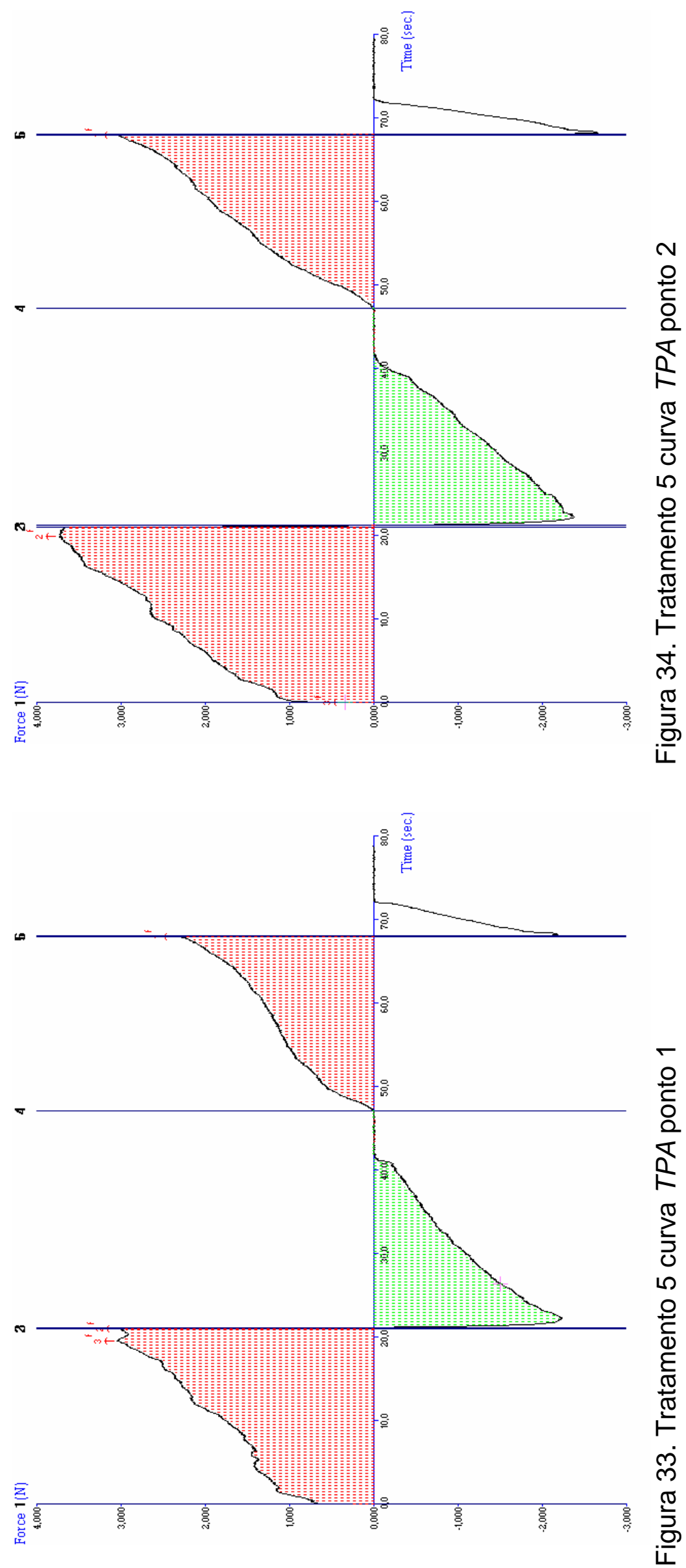

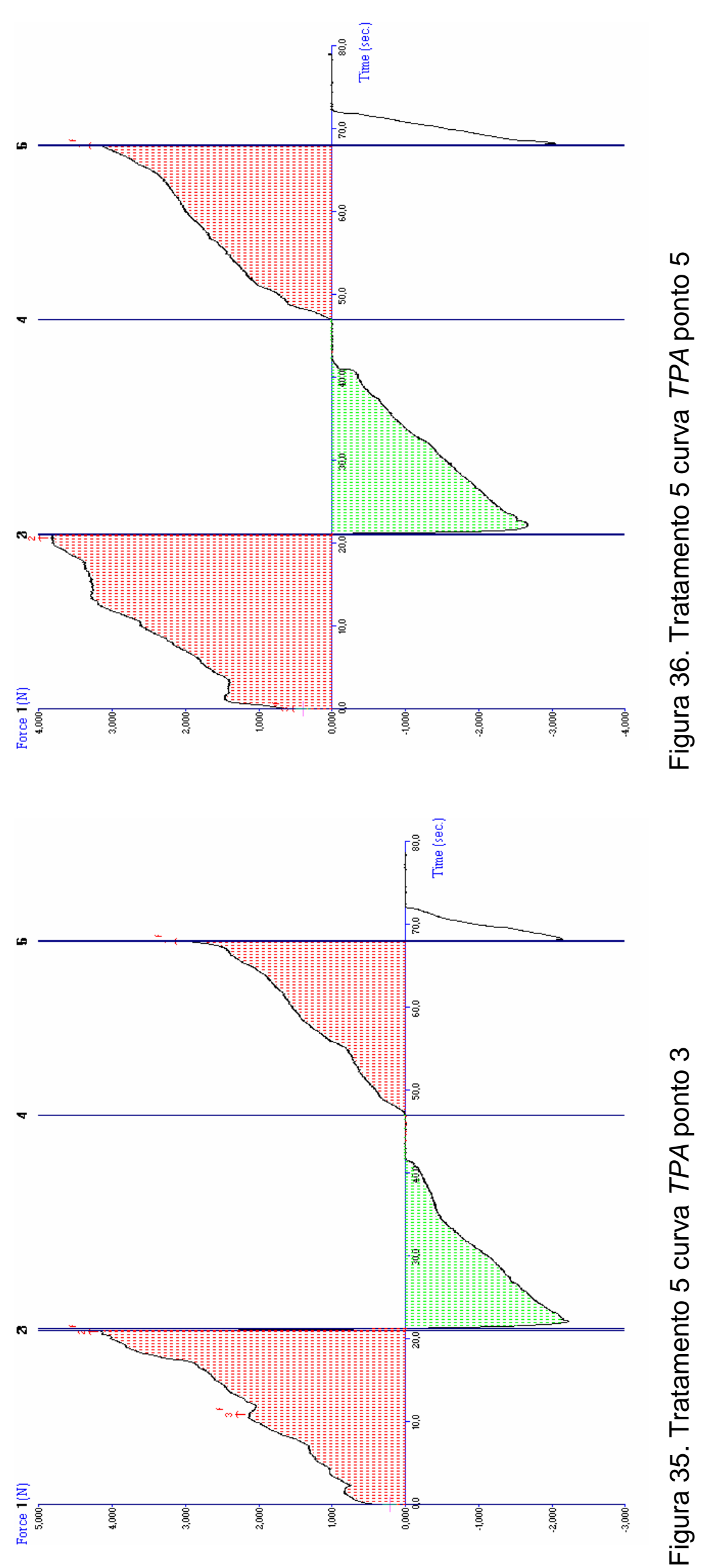

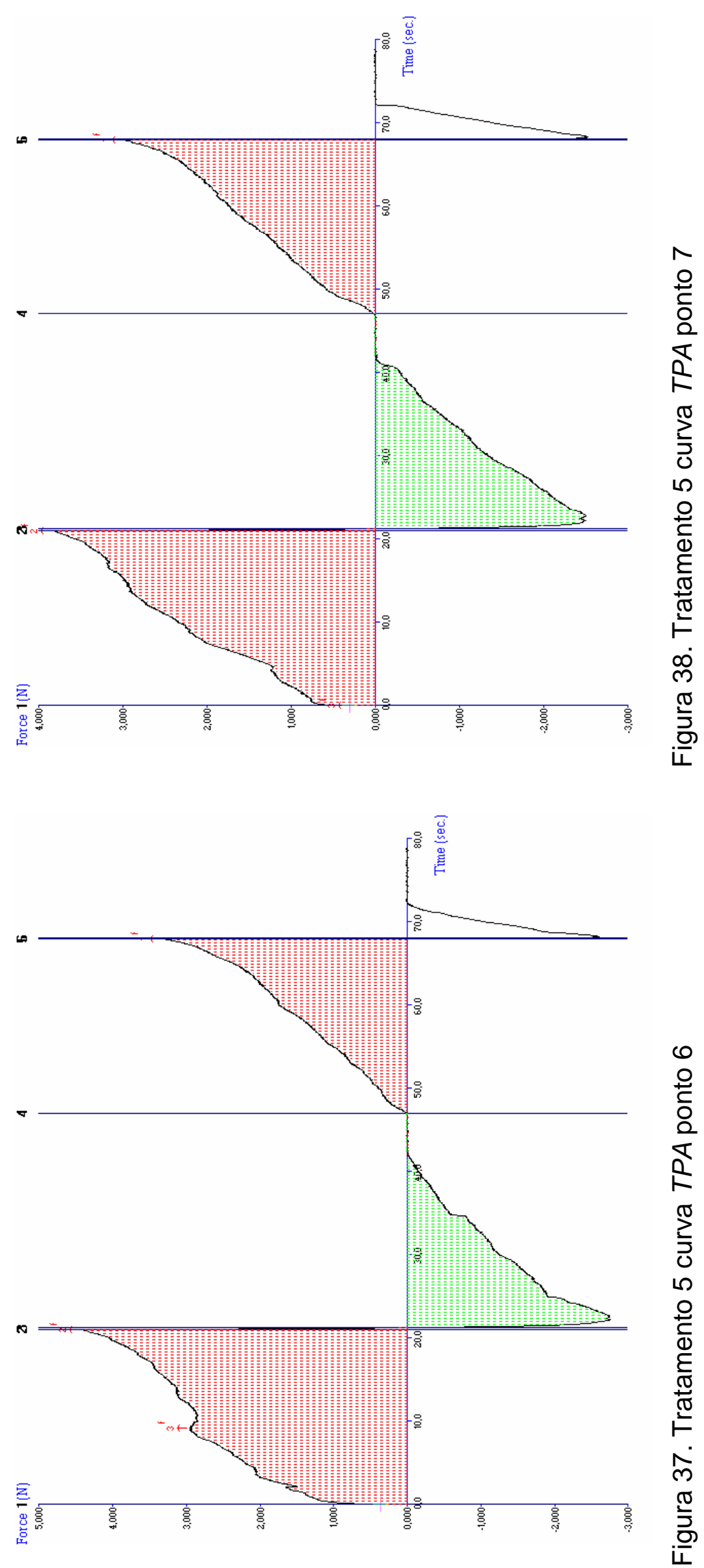

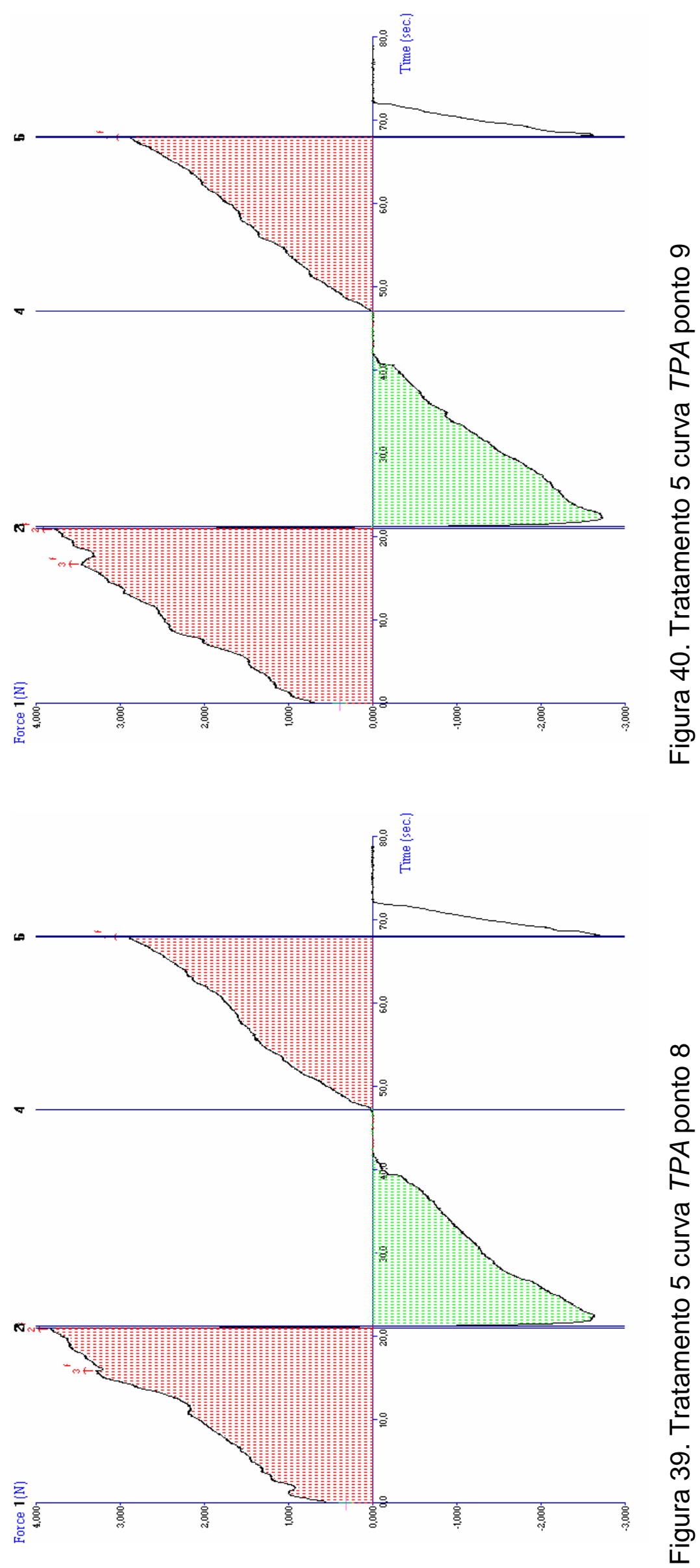

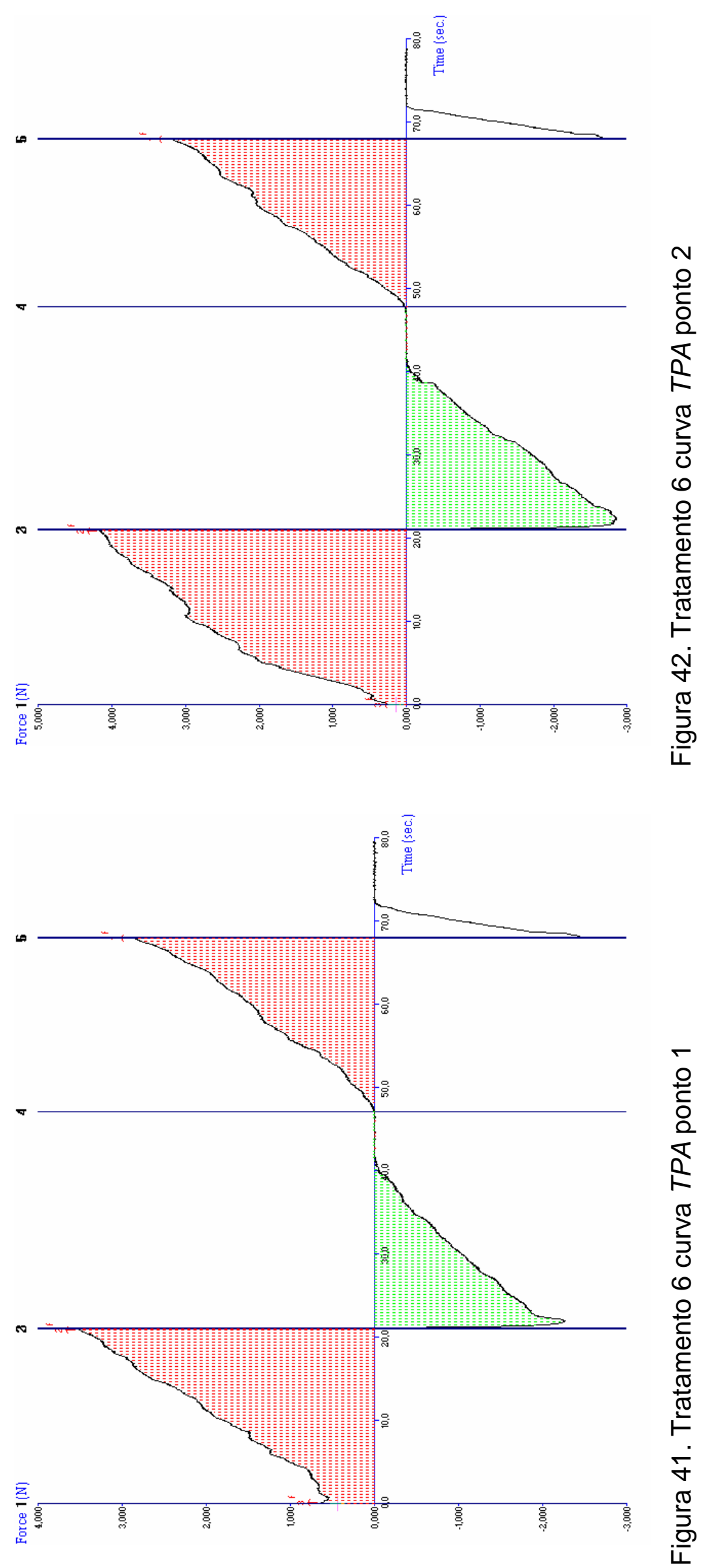

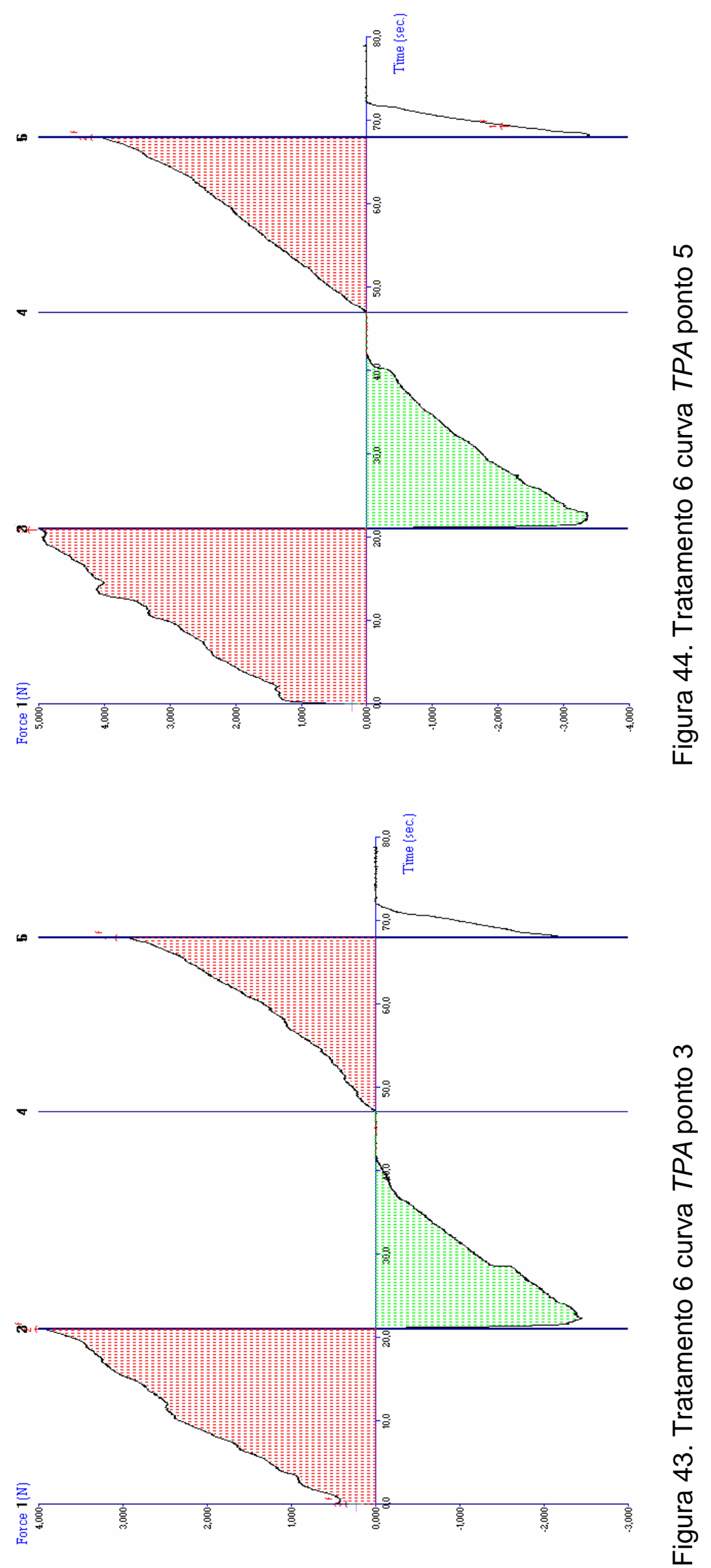

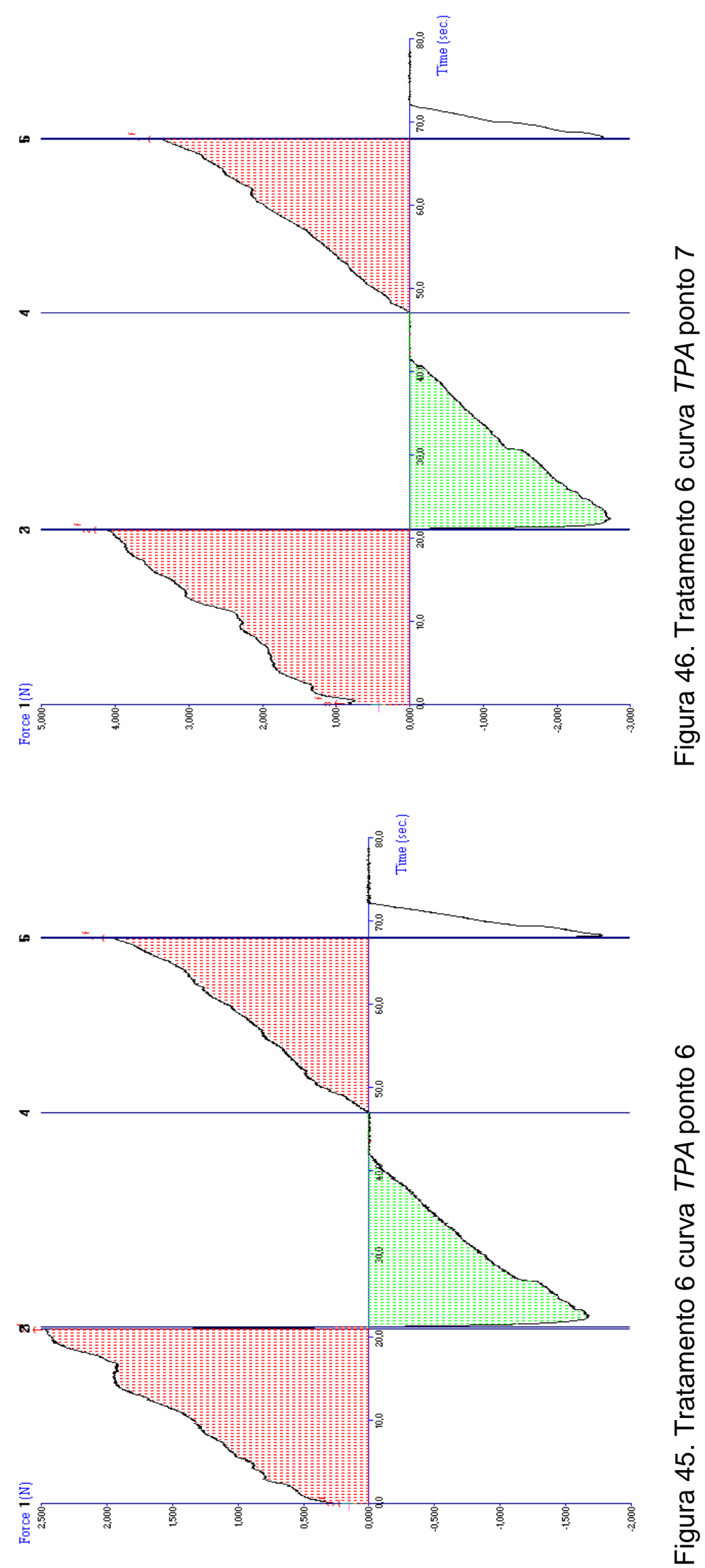

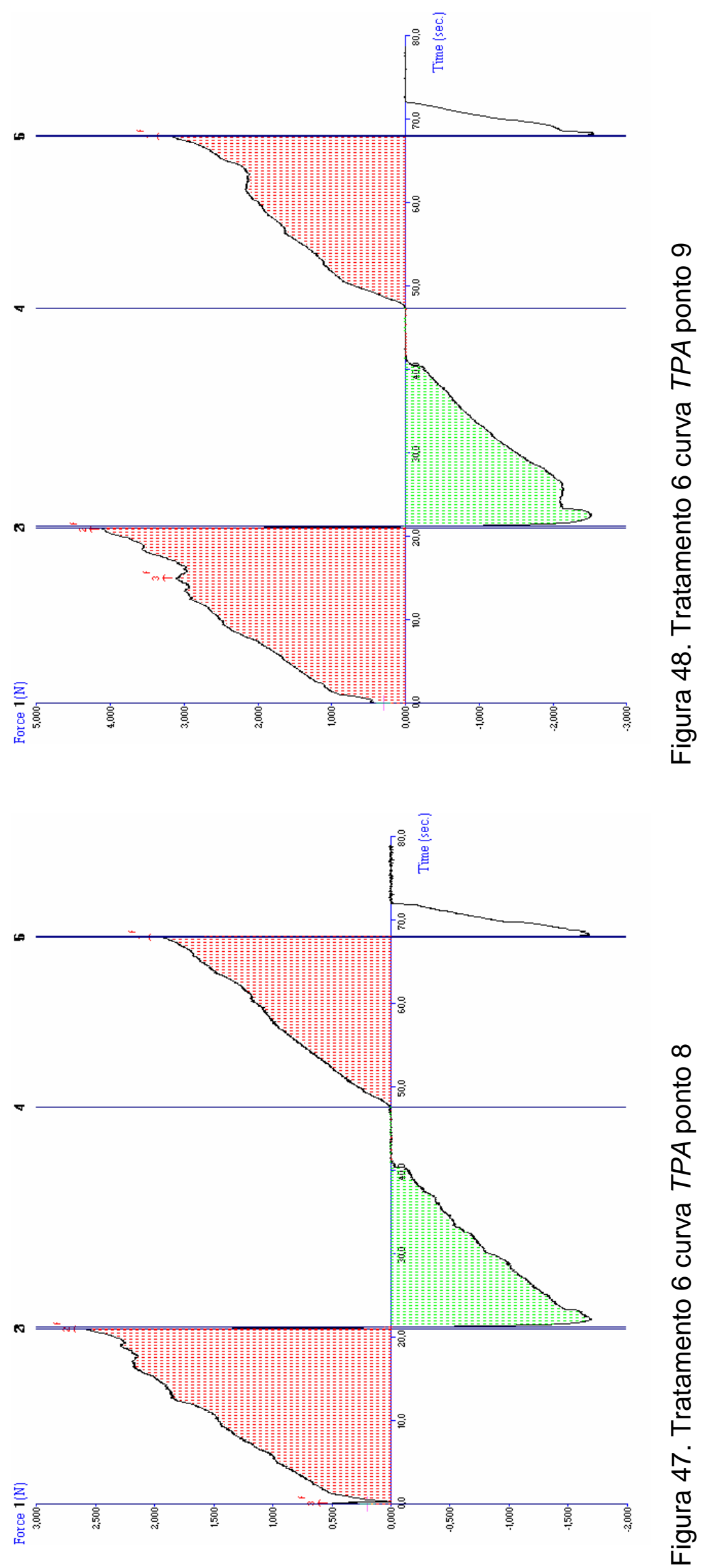


\section{Ronaldo Montezuma}

Possui Graduação em Medicina Veterinária pela Universidade Estadual do Ceará (UECE), com habilitação para supervisão de processamento térmico de alimentos (FDA) pelo Instituto de Tecnologia de Alimentos (ITAL) e especialização em Extensão Rural pela EMPAER (MT). Desenvolve pesquisas em processamento de produtos de origem animal. Tem experiência como executivo e consultor, tendo atuado na Sadia, Sonae e JBS, nos segmentos de alimentos e varejo, com ênfase em processamento e conservação de alimentos sem refrigeração, atuando principalmente nos seguintes temas: processamento térmico e concentração. Ingressou na Universidade Estadual Paulista (Unesp) em 2007 no Programa de PósGraduação em Engenharia e Ciência de Alimentos, nível Mestrado, na área de concentração em Engenharia de Alimentos, para atuar com o processamento térmico e textura de conservas de carne, sob orientação do Prof. Dr. Roger Darros-Barbosa. 
Autorizo a reprodução xerográfica para fins de pesquisa.

São José do Rio Preto, 1

Assinatura 